\author{
UNIVERSIDADE DE SÃO PAULO \\ FACULDADE DE FILOSOFIA, LETRAS E CIÊNCIAS HUMANAS \\ DEPARTAMENTO DE HISTÓRIA \\ PROGRAMA DE PÓS GRADUAÇÃO EM HISTÓRIA ECONÔMICA
}

\title{
A Imprensa Negra Paulista entre 1915 e 1937: características, mudanças e permanências.
}

Gilmar Luiz de Carvalho

Dissertação apresentada ao Programa de Pós Graduação em História do Departamento de História da Faculdade de Filosofia, Letras e Ciências Humanas da Universidade de São Paulo, para a obtenção de Mestre em História Econômica.

Orientadora: $\operatorname{Prof}^{\mathrm{a}} \operatorname{Dr}^{\mathrm{a}}$ Suely Robles Reis de Queiroz 


\title{
UNIVERSIDADE DE SÃO PAULO
}

FACULDADE DE FILOSOFIA, LETRAS E CIÊNCIAS HUMANAS DEPARTAMENTO DE HISTÓRIA

PROGRAMA DE PÓS GRADUAÇÃO EM HISTÓRIA ECONÔMICA

\author{
GILMAR LUIZ DE CARVALHO
}

\section{A Imprensa Negra Paulista entre 1915 e 1937: características, mudanças e permanências.}




\section{LISTA DE ABREVIATURAS E SIGLAS}

$\begin{array}{ll}\text { AIB } & \text { Ação Integralista Brasileira } \\ \text { CEDAP } & \text { Centro de Apoio à Pesquisa da Unesp de Assis } \\ \text { CCP } & \text { Centro Cívico Palmares } \\ \text { DIEESE } & \text { Departamento Intersindical de Estatística e Estudos Sócio-Econômicos } \\ \text { FFCL-USP } & \text { Faculdade de Filosofia, Ciência e Letras - USP } \\ \text { FFLCH-USP } & \text { Faculdade de Filosofia, Letras e Ciências Humanas - USP } \\ \text { FNB } & \text { Frente Negra Brasileira } \\ \text { IBGE } & \text { Instituto Brasileiro de Geografia e Estatística } \\ \text { IEB } & \text { Instituto de Estudos Brasileiros } \\ \text { IPEA } & \text { Instituto de Pesquisas Econômicas Avançadas } \\ \text { PEA } & \text { População Economicamente Ativa } \\ \text { PED } & \text { Pesquisa de Emprego e Desemprego } \\ \text { SEADE } & \text { Sistema Estadual de Análise de Dados } \\ \text { TEN } & \text { Teatro Experimental do Negro } \\ \text { USP } & \text { Universidade de São Paulo }\end{array}$




\section{LISTA DE ILUSTRAÇÕES}

FIGURA 1 - Igreja de Nossa Senhora do Rosário dos Homens Pretos

FIGURA 2 - Menelik II

TABELA 1 - As migrações Inter-regionais e Urbanas 38

GRÁFICO 1 - Percentagem da PEA com até o ensino médio incompleto. .42

GRÁFICO 2 - Percentagem da PEA do ensino médio completo ao superior completo

GRÁFICO 3 - Percentagem da PEA com ensino superior completo. 44

GRÁFICO 4 - Taxas de Acesso à Formação Superior Branca e Negra no Brasil 45

GRÁFICO 5 - Razão de renda entre brancos e negros (histórico) 46

GRÁFICO 6 - Razão de renda entre brancos e negros (projeção). .46

FIGURA 3 - Voltolino: "Coisas da Cidade" 101

FIGURA 3 - Voltolino: “A Água de S. Paulo”. 101

FIGURA 3 - Voltolino: "Carnaval no Braz" 102

FIGURA 3 - Voltolino: "Projectos Municipaes" 102 


\section{RESUMO}

O objetivo deste trabalho é mostrar a função que teve a Imprensa Negra como instrumento de reinvindicação de direitos e combate à exclusão sócio-político-econômica do negro em São Paulo, numa época de urbanização e crescimento industrial acelerados.Em decorrência das origens dessa exclusão, pretende-se relembrar o papel das Irmandades, Associações e primeiros jornais como focos iniciais de resistência à mesma. No entanto, o período escolhido para a pesquisa é aquele compreendido entre os anos de 1915 e 1937, quando, a par do interesse de congregar os negros através da educação e de outros meios, a Imprensa começa a reinvindicar os direitos que os mesmos deveriam ter como cidadãos integrantes da sociedade paulista e, por extensão, brasileira. A implantação do Estado Novo em 1937 determina o fechamento dos partidos políticos, associações e jornais a eles ligados, razão pela qual a historiografia considera a data como a de decadência dos jornais negros e, portanto, de suas reinvindicações. Tentaremos mostrar, entretanto, como as disputas ideológicas e por poder entre as lideranças, mudando o perfil de atuação dos periódicos, foram decisivos para a decadência do caráter reinvindicatório dos mesmos, tendo se iniciado bem antes do golpe de Getúlio Vargas.

Palavras-chave: Escravidão - Exclusão - Jornais - Negro - Reivindicações 


\begin{abstract}
The aim of this master thesis is to show the role of Black Press as instrument of rights claiming and the struggle against social, political e economical exclusion of Brazilian black people in São Paulo in a time of fast urbanization and industrial growth. Considering the origins of that social exclusion, this paper intends to remember the role of Brotherhoods, Associations and former black journals as the initial process for fighting that exclusion. Nevertheless the chosen period for this research is between 1915 and 1937, when, besides the interest in congregating the blacks through education and other means, the Black Press starts claiming the rights that people should have as integrated citizens in São Paulo society and, as a consequence, in Brazilian society. The implementation of Estado Novo in 1937 determines the political parties' shut down as well as the associations and journals associated to them, being this event the main reason the Historiography considers that year as the highlight of black journal's decadence, so do their claims. However, we will try to demonstrate how the ideological disputes and struggle for power among the leaders, by the acting profile of journals, were crucial for the decadence of journal's claiming approach, getting started quite before the Getúlio Vargas' coup.
\end{abstract}

Key Words: Slavery - Exclusion - Journal - Brazilian Black People - Claims 


\section{SUMÁRIO}

INTRODUÇÃOO

7

CAPÍTULO 1 - RAÍZES DA IMPRENSA NEGRA: A EXCLUSÃO

SOCIAL

CAPÍTULO 2 - PRIMEIRAS REAÇÕES COLETIVAS À EXCLUSÃO:

IRMANDADES E OUTRAS ASSOCIAÇÕES

CAPÍTULO 3 - NOVAS REAÇÕES COLETIVAS À EXCLUSÃO:

OS PRIMEIROS JORNAIS 66

CAPÍTULO 4 - EVOLUÇÃO DA IMPRENSA NEGRA

NO QUADRO HISTÓRICO PAULISTA …………………………………........... 100

4.1. Crescimento e desenvolvimento da Imprensa Negra ............................ 110

4.2. A criação da Frente Negra Brasileira e a Voz da Raça ......................... 161

\section{CAPÍTULO 5 - AS DISPUTAS ENTRE AS LIDERANÇAS DA} IMPRENSA NEGRA E SUAS CONSEQUÊNCIAS.................................................. 174

5.1. Cenário Político, embates ideológicos e a luta por poder 174

5.1.1. Disputas entre lideranças: Arlindo Veiga e José Correia Leite........ 175

5.1.2. Outras Lideranças: Lino Guedes, Gervásio de Moraes,

Correia Leite e Vicente Ferreira ................................................... 179

5.1.3. Lealdade, dissensão e luta armada ............................................... 183

5.2. Permanências e mudanças. O declínio do caráter reivindicatório

nos jornais negros ....................................................................... 186

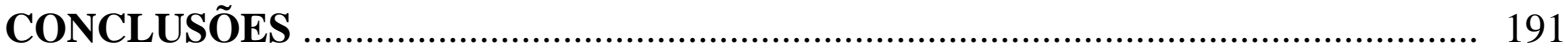

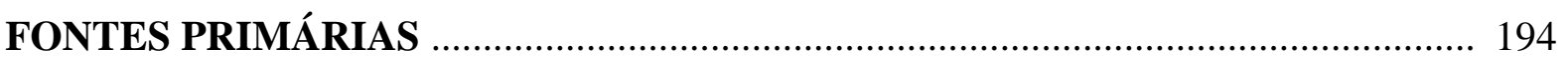

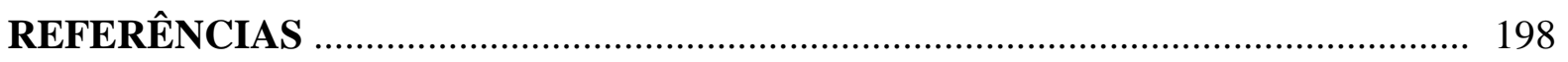

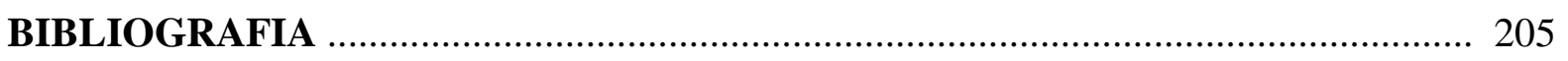

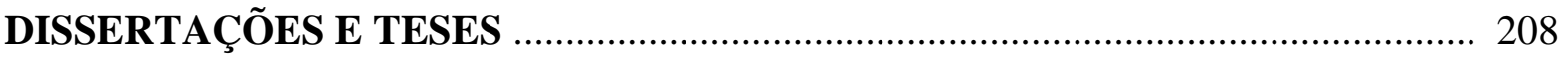




\section{Introdução}

Falar sobre a Imprensa Negra paulista é lembrar que ela está intimamente ligada ao movimento negro ${ }^{1}$ e que começou a estabelecer-se de maneira mais sequente e organizada a partir do início do século XX, quando se tornam claramente perceptíveis os objetivos e a maturidade de seus dirigentes.

O primeiro momento significativo dessa Imprensa ocorre em 1915 - data de fundação do jornal $O$ Menelik. Não se buscava então apenas uma identificação e integração com a sociedade de brancos em São Paulo, mas a conscientização do negro como elemento participante da sociedade e da história brasileiras.

A fase mais intensa da Imprensa Negra ocorreu a partir de 1923, com a fundação do Getulino, de Lino Guedes, e com o jornal O Clarim da Alvorada, de José Correia Leite e Jayme de Aguiar, surgido em 1924, segundo nossa periodização, que será explicada em detalhes no decorrer do trabalho.

A abordagem realizada pelos periódicos negros passa a ser mais incisiva. Além de reforçar o sentimento de integração na sociedade brasileira, enfatizavam a necessidade de reivindicar direitos legítimos de cidadãos através da luta contra os males internos e externos que afligiam a população negra naquele momento.

A instauração do Estado Novo, entretanto, enfraquece o movimento negro e as instituições a ele ligadas. Para isso, colaboraram também a sempre presente discriminação da população branca e os problemas estruturais da própria nação brasileira. Caracterizada desde sempre pela grande concentração de renda nas mãos de uma elite pouco numerosa, tal fato agravou ao longo dos anos a já difícil situação de acesso do negro às oportunidades de trabalho.

As circunstâncias acima mencionadas delimitaram os marcos cronológicos do presente estudo, ou seja, cirscunscreveram-no ao período 1915-1937. Evidentemente, os objetivos, esperanças e ações do meio negro, representados pela Imprensa Negra, continuaram a existir

\footnotetext{
${ }^{1}$ Concordamos com Regina Pahim Pinto que o movimento negro é "a luta dos negros na perspectiva de resolver seus problemas na sociedade abrangente, em particular os provenientes dos preconceitos e das discriminações raciais, que os marginalizam no mercado de trabalho, no sistema educacional, político, social e cultural", Cf. PINTO, Regina Pahim. O movimento negro em São Paulo: luta e identidade. Tese de Doutorado: São Paulo: FFLCH,USP, 1993.
} 
ao longo das décadas seguintes, com maior ou menor vigor, mas escapam à cronologia de nosso estudo.

O recorte espacial escolhido foi São Paulo, pois entendemos que o processo acelerado de urbanização e os anseios de modernidade surgidos no período escolhido foram muito importantes para acentuar a exclusão do negro no ambiente urbano. Além disso, o estado paulista e, sobretudo sua Capital, representou o locus privilegiado para o exame da transição do trabalho escravo ao assalariado após a Abolição. Sobre esse cenário, a constatação de Florestan Fernandes é exemplar:

São Paulo constituía, naquela época, uma das cidades paulistas e brasileiras menos
propícia à absorção imediata do elemento recém-egresso da escravidão. Sobre o
pano de fundo da concepção tradicionalista do mundo e da dominação
patrimonialista (exercida por reduzido número de famílias "gradas" e "influentes"),
São Paulo aparecia como o primeiro centro urbano especificamente burguês. Não só
prevalecia entre os homens uma mentalidade marcadamente mercantil, com seus
corolários característicos - o afã do lucro e a ambição do poder pela riqueza.
Pensava-se que o "trabalho livre", a "iniciativa individual" e o "liberalismo
econômico" eram os ingredientes do "progresso", a chave que iria permitir superar o
"atraso do país" e propiciar a conquista dos foros de "nação civilizada" pelo Brasil.

Como foi visto pelo título da Dissertação e pelas páginas anteriores, nossa proposta de estudo está baseada na análise de jornais. Repetindo as palavras de Lilia Schwarcz, "o jornal é eficaz, então, porque trabalha com e cria consensos, opera com dados num primeiro momento explícitos, e que na prática diária de repetições e reiterações tornam-se cada vez mais implícitos, reforçando-se enquanto verdades ou pressupostos intocáveis". 3

Em São Paulo também encontramos o maior número de jornais negros criados em todo o país nas primeiras quatro décadas do século XX. Muitos deles foram fundados mediante o vínculo com associações beneficentes e irmandades negras, como veremos mais adiante.

Embora ainda haja muito a esclarecer, já se podem apontar vários trabalhos sobre o tema. Entre eles, o da professora Miriam Nicolau Ferrara ${ }^{4}$, originalmente apresentado como Dissertação de Mestrado ao Departamento de Ciências Sociais da FFLCH-USP, em 1981. Reúne rica documentação, composta por vasto acervo de jornais ligados à imprensa negra de

\footnotetext{
${ }^{2}$ FERNANDES, Florestan. A integração do negro na sociedade de classes: ensaio de interpretação sociológica. Vol. I. São Paulo: Globo, 2008, p.34

${ }^{3}$ SCHWARCZ, Lilia Moritz. Retrato em branco e negro: jornais, escravos e cidadãos em São Paulo no final do século XIX. São Paulo: Companhia das Letras, 1987, p. 248.

${ }^{4}$ FERRARA, Miriam Nicolau. A imprensa negra paulista (1915-1963). São Paulo: FFLCH/USP, 1986.
} 
São Paulo e outros estados, com depoimentos de alguns de seus líderes e militantes, nos quais podem ser vistos o mundo ideológico do negro paulista, suas esperanças, comportamento e reações. Os exemplares dos jornais utilizados no trabalho foram doados e encontram-se disponíveis na biblioteca do IEB - Instituto de Estudos Brasileiros da Universidade de São Paulo (USP).

Um dos aspectos interessantes do estudo da autora é a revisão que faz da periodização apresentada por Roger Bastide 5 . O sociólogo francês dividiu a história dessa Imprensa em três períodos: o primeiro, após 1915; o segundo, entre 1930 e 1937, e o terceiro, depois de 1945. O período inicial acompanharia ou viria em seguida à Primeira Grande Guerra Mundial, quando a parte social dos jornais tem ainda uma importância considerável. Divulgando as ideias de liberdade e igualdade, a guerra despertaría a população negra para a busca de concretização de suas aspirações. Concomitantemente, surgiam os primeiros efeitos da política de educação no Brasil, como resultado do esforço do Governo a fim de desenvolver o ensino primário gratuito. A necessidade de instrução e educação passa a fazer parte do conjunto de reivindicações dos jornais negros, e é vista como um meio de ascensão social.

O segundo período é o da formação, desenvolvimento e apogeu da Frente Negra Brasileira, uma associação recreativa e cultural fundada em 1931, cujo objetivo era a afirmação dos direitos históricos dos negros, e da criação do jornal $A$ Voz da Raça, em 1933, o principal veículo de divulgação da Frente. Nas palavras de Roger Bastide, "a criação do

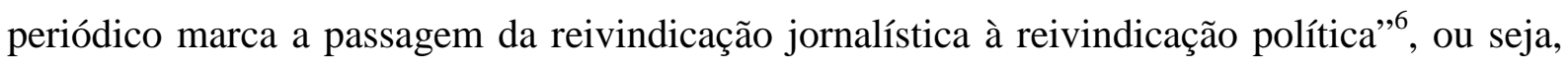
enquanto jornal, por muito tempo denunciou o racismo e a necessidade de valorização e disciplina da população negra para o obter o reconhecimento da cidadania brasileira. A partir de 1936, quando a Frente Negra Brasileira se torna um partido político, A Voz da Raça passa a exercer importante papel na disseminação dos ideais políticos de seus membros.

Finalmente, o terceiro período seria marcado pela instauração do Estado Novo em 1937, com a supressão de todos os partidos políticos e o regime de censura à imprensa, o que determinou o fechamento da Frente Negra Brasileira e também dos jornais negros.

\footnotetext{
${ }^{5}$ BASTIDE, Roger. A imprensa negra do Estado de São Paulo. Universidade de São Paulo. Faculdade de Filosofia, Ciências e Letras. Boletim CXXI. Sociologia n. 2. Estudos Afro-Brasileiros, 2a . Série, 1951.

${ }^{6}$ BASTIDE, Roger. A imprensa negra do Estado de São Paulo. In: Estudos Afro-brasileiros. São Paulo: Perspectiva, 1973, p. 132.
} 
Esse quadro iria mudar de forma mais significativa somente com a volta da redemocratização do país. Surgem então os jornais Alvorada e Senzala, cuja análise foge a o nosso balizamento cronológico.

Utilizando-se de uma reanálise dos conteúdos dos jornais negros, mas ao mesmo tempo reconhecendo que dispõe de material mais recente em relação à obra de Roger Bastide, Miriam Nicolau Ferrara propõe que as fases da imprensa negra paulista sejam delimitadas da seguinte forma: o primeiro período, entre 1915 e 1923; o segundo, de 1924 a 1937; e o terceiro, entre 1945 e 1963.

No primeiro estaria presente o caráter recreativo, informativo e beneficente e seu término é marcado pela fundação em 1923 do jornal Getulino. ${ }^{7}$

O segundo período seria inaugurado com a fundação, em 1924, do jornal O Clarim da Alvorada. O aparecimento da Frente Negra estaria inserido nessa fase que terminaria em 1937, com o Estado Novo.

A terceira fase se iniciaria em 1945, com a reorganização do movimento negro e terminaria em 1963, quando se paralizaram as ações de militância. A retomada só aconteceria em meados de 1970.

Pretendemos, no entanto, ao longo deste trabalho, propor uma periodização diferente, que será justificada ao longo do mesmo e que começa em 1923.

Florestan Fernandes também se interessou pelo tema. Publicada em 1965 e, originariamente sua tese de cátedra em Sociologia, intitulada A Integração do Negro na Sociedade de Classes $^{8}$ analisa o processo de urbanização e industrialização em São Paulo a partir de 1900, incluindo o traçado histórico do aparecimento dos jornais e dos movimentos negros, suas reivindicações, manifestações e esperanças.

Situando a problemática na transição "da ordem social escravocrata e senhorial" para o "desenvolvimento posterior do capitalismo", o sociólogo constrói uma forma particular de tratar o assunto, evidenciando a condição de marginalidade dos negros e mulatos:

\footnotetext{
${ }^{7}$ Segundo Roger Bastide, o Getulino teria sido fundado em 1919. No capítulo 1 de seu livro, Miriam Nicolau Ferrara desfaz o equívoco.

${ }^{8}$ FERNANDES, Florestan. A integração do negro na sociedade de classes. Tese de Cátedra em Sociologia. São Paulo: Faculdade de Filosofia, Ciências e Letras, USP, 1964.
} 
Desse modo,

No período em que as famílias dos fazendeiros paulistas começam a fixar residência em São Paulo e em que se acentua a diferenciação do sistema econômico da cidade, o liberto se defrontou com a competição do imigrante europeu, que não temia a degradação pelo confronto do negro e absorveu, assim, as melhores oportunidades de trabalho livre e independente.

(...) Quando se acelera o crescimento econômico da cidade, ainda nos fins do século XIX, todas as posições estratégicas da economia artesanal e do pequeno comércio urbano eram monopolizadas pelos brancos e serviam como trampolim para as mudanças bruscas de fortuna, que abrilhantam a crônica de muitas famílias estrangeiras. Eliminado para os setores residuais daquele sistema, o negro ficou à margem do processo, retirando deles proveitos personalizados, secundários e ocasionais. ${ }^{9}$

É nesse quadro de crescente pujança econômica, rápida urbanização, multiplicação dos habitantes e grande diversidade de etnias que ele analisa os impasses vivenciados por negros e mulatos no esforço de inserção na nova ordem social, pontuada pelo "estilo de vida individualista e competitivo", construído pelo "novo regime de relações de produção". ${ }^{10}$

A rápida transformação ocorrida na cidade, entre o fim do século XIX e o início do XX, teria impossibilitado, segundo Florestan, a inserção do negro e do mulato no estilo urbano de vida. Profundos desajustamentos resultaram desse processo, respondendo pela desorganização desses indivíduos no novo contexto social.

A extinção da escravatura não promoveu a reintegração dos egressos. Ao contrário, desterrou-os para as sombras da sociedade que se modernizava e caminhava para uma maior complexidade de classes sociais:

Nas condições econômicas e sociais que se criam, então, duas categorias sociais se beneficiam, amplamente, com os proventos econômicos, sociais e políticos da industrialização: os que detinham os papéis de capitalistas, como "donos" das empresas nascentes; o que conseguiam vender sua força de trabalho, como "operários". Embora os elementos nacionais se incluíssem em ambas as categorias, o negro e o mulato delas participaram em proporções ínfimas. ${ }^{11}$

O fato de a urbanização e a industrialização se darem, em grande parte, como consequência da imigração, concedia ao imigrante uma posição altamente vantajosa em relação ao elemento nacional e, em segundo lugar, quase anulava as possibilidades de competição do negro e do mulato, automaticamente deslocados para os setores menos favorecidos do conglomerado nacional. ${ }^{12}$

\footnotetext{
${ }^{9}$ FERNANDES, Florestan. A integração do negro na sociedade de classes...Op. cit., pp. 33-34

${ }^{10}$ FERNANDES, Florestan. Op. cit., Apud ARRUDA, Maria Arminda do Nascimento. Assimilação marginal ao mundo do trabalho livre. São Paulo. Folha On-line: História do Brasil. Disponível em <http://www1.folha.uol.com.br/fol/brasil500/zumbi_29.htm> Último acesso em 29.06.2009.

${ }^{11}$ FERNANDES, Florestan. A integração do negro...p.162.

${ }^{12}$ Idem, ibidem, p. 163.
} 
Dessa forma, o sociólogo reitera sua persistência e interesse no tema das relações inter-étnicas, já revelados em uma pesquisa na qual colaborou com Roger Bastide. ${ }^{13}$

Nesse livro os autores estudam a evolução do sistema econômico paulistano e seus reflexos na alteração da situação econômica do negro. Além disso, examinam a evolução do sistema social e a maneira pela qual as relações entre negros e brancos foram sucessivamente condicionadas pela posição recíproca dos representantes das duas raças ou de seus descendentes mestiços na estrutura social. Há um levantamento sociográfico das situações de convivência social que mostra quanto o negro recebia tratamento discriminatório e preconceituoso. Mas também são postas em relevo as tendências ou medidas de combate à discriminação racial e ao preconceito de cor levadas a cabo por negros, brancos e órgãos do governo brasileiro:

O preconceito de côr, cuja função era justificar o trabalho servil do africano, vai servir agora para justificar uma sociedade de classes, mas nem por isso vão variar os esteriótipos antigos; mudarão apenas de finalidade. Entrentanto, um novo tipo de prêto afirma-se cada vez mais, com a transformação do escravo em cidadão, e o branco não sabe mais que atitude tomar para com êle, pois os esteriótipos tradicionais já não se aplicam a êsse negro que sobe na escala social. ${ }^{14}$

Em outro livro publicado em 1971, Florestan Fernandes ${ }^{15}$ reúne uma coletânea de quatorze ensaios sobre a situação do negro e do mulato na sociedade brasileira, os quais possuem como temática central a discussão sobre como a realidade social no país foi moldada pelo branco e para o branco (na verdade, para o branco privilegiado). Negros e mulatos, apesar de sua importância na construção desse mundo, nunca puderam decidir sobre como seria ele. Tampouco conseguiram manter as bases de sua identidade e de sua herança cultural. Ambos foram anulados em seu ímpeto reivindicatório, através de conhecidos mecanismos de mobilidade social seletiva, ou então "convencidos" a adotarem o modelo de convivência pacífica com os brancos, sendo considerados não poucas vezes como a "exceção que confirmaria a regra."

A perpetuação indefinida do status quo racial brasileiro está fundamentada em dois pólos: os efeitos estáticos do comportamento dos "brancos" e uma modalidade de acomodação racial por parte dos "negros" e dos "mulatos", o que descrevemos como capitulação passiva. A substância do equilíbrio racial da sociedade brasileira procede do modo pelo qual os dois polos se articulam com um mínimo de fricção, a qual

\footnotetext{
${ }^{13}$ BASTIDE, Roger e FERNANDES, Florestan. Brancos e negros em São Paulo: ensaio sociológico sobre aspectos da formação, manifestações atuais e efeitos do preconceito de côr na sociedade paulistana. $2^{\mathrm{a}}$. edição. São Paulo: Companhia Editora Nacional. 1959.

${ }^{14}$ Idem, ibidem, p. 13.

${ }^{15}$ FERNANDES, Florestan. O negro no mundo dos brancos. Corpo e Alma do Brasil. São Paulo: Difel, 1972, p. 42.
} 
pode ser inclusive, identificada, condenada e absorvida, sem nenhuma alteração da ordem racial existente. Esse modelo visa a perpetuar o quadro de desigualdade racial, pois a ascensão do negro e do mulato se dará dentro de um processo de acumulação de vantagens que privilegia o branco. ${ }^{16}$

Maria Isaura Pereira de Queiroz é outra autora que tratou da ascensão sócioeconômica dos negros no Brasil. Em Coletividades Negras, aborda a situação do liberto sob a ótica do aburguesamento nas grandes cidades brasileiras, sobretudo as do Sudeste, a rejeição pelo branco e a exclusão do mercado de trabalho:

Os antigos escravos [passaram] a formar um subproletariado miserável, sobretudo nas cidades do Sul do país. (...) as grandes cidades brasileiras foram submetidas a um processo de aburguesamento no decorrer do século XIX. Os antigos escravos, não apresentando características requeridas para se adaptarem às exigências urbanas principalmente à expansão da administração pública, dos serviços, do comércio, foram rejeitados para uma camada social inferior à dos imigrantes brancos. ${ }^{17}$

A socióloga também entende que a população negra sempre se comportou de forma heterogênea, mesmo durante o período da escravidão, e isso teria prejudicado o sentimento de solidariedade no processo de mobilidade social a partir das camadas inferiores da população negra:

\begin{abstract}
A satisfação dos que haviam conseguido se elevar agia em sentido contrário à solidariedade étnica: não queriam ser mais confundidos com os 'irmãos de cor', que haviam permanecido na parte mais baixa da escala sócio-econômica. Além disso, também havia um reforço da adoção dos valores brancos que ascendiam e um diligência em se mostrarem, mais ainda que os brancos, os cultores dos mesmos valores; estes comportamentos iam na mesma linha de apagar a origem, permanecendo apenas como elemento de distinção a cor da pele. ${ }^{18}$
\end{abstract}

Nossas pesquisas mostraram que a imitação dos valores inerentes à população branca como tentativa de ascensão social foi tema abordado pelos jornais e lideranças, principalmente nos primeiros anos de atuação da imprensa negra, porém não ocorreu de forma generalizada ou sistemática. Voltaremos ao tema quando tratarmos dos primeiros jornais.

Clóvis Moura, o primeiro historiador a tratar de rebeliões escravas, defende a ideia de que a formação dos quilombos seria o resultado da organização de lutas determinada pela formação escravista. Por sua vez, a formação capitalista atualizaria os conflitos raciais enquanto expressão do antagonismo entre classes sociais e sua estratificação.

\footnotetext{
${ }^{16}$ FERNANDES, Florestan. O negro no mundo dos brancos... p. 10.

${ }^{17}$ QUEIROZ, Maria Isaura Pereira de. Coletividades negras: ascensão sócio-econômica dos negros no Brasil e em São Paulo. São Paulo: Revista Ciência e Cultura, 29 de setembro de 1977, p. 650 Apud FERRARA, Miriam Nicolau. Op. cit., p. 34.

${ }^{18}$ Idem, ibidem, pp. 652-653
} 
(...) o conjunto de grupos e entidades organizacionais negras - dentro de um gradiente de conscientização que somente poderá ser estabelecido depois do estudo pormenorizado de cada um - são grupos específicos numa sociedade de classes, no caso brasileiro dentro de uma sociedade de modelo capitalista. ${ }^{19}$

No protesto racial existiria um potencial mobilizador capaz de engendrar formas organizadas de luta para superar as contradições sociais. Assim, aquilo que a antiga formação sócio-econômica impedia os negros de realizarem, ou seja, uma leitura revolucionária da realidade, tinha grande chance de acontecer no interior da sociedade capitalista moderna, à medida que os militantes negros pudessem captar nos conflitos raciais os antagonismos das classes sociais.

Para ele, o negro brasileiro sempre exerceu um papel organizador. Exemplos disso seriam, além da criação dos quilombos, as confrarias religiosas e o candomblé, os quais, mesmo apresentando estruturas frágeis, demonstram ser organizações constantes no tempo ${ }^{20}$. O negro sempre buscou um reencontro com suas origens étnicas ou lutou através de organizações, para não ser destruído social, cultural e biologicamente. ${ }^{21}$

É de George Reid Andrews ${ }^{22}$ um trabalho referente à questão dos escravos e libertos no Brasil, além de jornais das imprensas negra, tradicional e operária nos cem anos que se seguem após a abolição. Andrews examina os esforços dos negros para ascender à classe média, bem como as dificuldades impostas pelos brancos, os quais, em uma sociedade racial informal, tendiam a excluir os afro-brasileiros das profissões liberais e de outros empregos.

$\mathrm{O}$ autor menciona também a criação, a atuação e as causas do fracasso da Frente Negra Brasileira ${ }^{23}$ no sentido de "mobilizar um número grande e organizado de adeptos para se tornar uma força política e, finalmente, melhorar significativamente as posições social, econômica e política da população negra de São Paulo" ${ }^{24}$. Ao mesmo tempo que reitera os problemas mais aparentes, como o "autoritarismo, o chauvinismo de extrema direita", a dificuldade de conseguir um total significativo de adesões, Andrews considera que a Frente foi vítima do cenário político-econômico do país ao final dos anos 1930:

\footnotetext{
${ }^{19}$ MOURA, Clóvis. O negro, de bom escravo a mau cidadão? Universidade da Virgínia: Conquista, 1977, p. 10.

${ }^{20}$ MOURA, Clóvis. Brasil: as raízes do protesto negro. São Paulo: Global Editora, 1983, p. 47.

${ }^{21}$ MOURA, Clóvis. Os quilombos e a rebelião negra. Coleção "Tudo é História”. Editora Brasiliense. 7ª Edição. São Paulo: 1987.

${ }^{22}$ ANDREWS, George Reid. Negros e brancos em São Paulo (1888-1988). Bauru:EDUSC, 1998.

23 A Frente Negra Brasileira foi criada em 1931 pelos irmãos Arlindo e Isaltino Veiga Santos e por exintegrantes do Centro Cívico Palmares e é considerada por muitos historiadores a entidade mais representativa dos direitos da população negra até hoje. Trataremos dela mais à frente.

${ }^{24}$ ANDREWS, George. op. cit., p. 240
} 
Os negros e brancos da classe média de São Paulo mostraram-se igualmente vulneráveis à sedução do nacionalismo xenofóbico e do autoritarismo político. Rompida pela resultante polarização entre uma direita de inspiração fascista e uma esquerda mais fraca, apoiada nos trabalhadores, a Frente repetiu em um microcosmo a trajetória da política paulista e brasileira como um todo durante a década de $1930 .^{25}$

O pesquisador se engana, no entanto, quando afirma que Arlindo Veiga dos Santos, "um dos participantes de maior destaque da vida cívica em São Paulo durante a década de 1920 „26 , foi presidente do Centro Cívico Palmares. Na verdade, esse Centro foi fundado em 28 de dezembro de 1926 por Antonio Carlos, um ex-sargento da Força Pública de Campinas e o irmão de Arlindo, Isaltino Veiga dos Santos, é que fez parte da primeira diretoria da referida organização, como consta dos estatutos da mesma.

No apêndice "c" do livro, George Andrews traz alguns dados interessantes sobre a presença de negros em duas empresas: a Companhia Jafet e a São Paulo Tramway, Light and Power. Nas duas, a mão de obra negra ou parda se iguala à mão-de-obra branca em número de empregados. $^{27}$

Ainda quanto aos negros na São Paulo republicana, cabe lembrar a importância do trabalho de Márcio Barbosa ${ }^{28}$, pesquisador do Quilombhoje Literatura ${ }^{29}$, grupo paulistano de escritores fundado em 1980 com o objetivo de discutir e aprofundar a experiência afrobrasileira na literatura. Nesse sentido, busca incentivar o hábito da leitura e promover a difusão de conhecimentos e informações, bem como desenvolver e incentivar estudos, pesquisas e diagnósticos sobre literatura e cultura negra.

Barbosa traz, de forma condensada, textos e entrevistas com alguns importantes líderes e participantes da Frente Negra Brasileira no período de 1931 a 1937. Para ele, trata-se de recuperar através da palavra impressa um pouco da história de vida dessas pessoas, as suas motivações, expectativas, formas de organização e como reagiram a problemas que ainda estão presentes no cotidiano da população negra.

As experiências contidas nos depoimentos mostram acontecimentos e curiosidades cotidianas que muitas vezes não encontramos nas fontes mais consultadas, como livros ou os

\footnotetext{
${ }^{25}$ Idem, ibdem, p. 241

${ }^{26}$ Idem, ibdem, p. 230

${ }^{27}$ O levantamento nessas fontes foi feito entre 1909 e 1960, com ênfase para o período que compreende a década de 1930.

28 BARBOSA, Márcio (org.). Frente Negra Brasileira: depoimentos/entrevistas e textos. São Paulo: Quilombhoje, 1998.

${ }^{29}$ Para maiores informações sobre Quilombhoje, ver <http://www.quilombhoje.com.br/>.
} 
próprios jornais negros, permitindo compreender muito mais a respeito da realidade não só de um pequeno grupo, mas de toda a comunidade negra de São Paulo durante o período em que a Frente Negra atuou. Por exemplo: o aluguel de bondes para buscar visitantes de comunidades negras do interior, a convivência com os italianos que possuíam casas próprias e alugavam cortiços para os negros na parte inferior delas e outras particularidades.

José Correia Leite, um dos fundadores de um jornal que será devidamente analisado mais à frente, teve sua vida retratada em livro ${ }^{30}$ por Luiz Silva, o "Cuti", que nasceu em Ourinhos, Estado de São Paulo, em 1951, e formou-se em Letras (Português-Francês) na Universidade de São Paulo, em 1980. Mestre em Teoria da Literatura e Doutor em Literatura Brasileira pelo Instituto de Estudos da Linguagem - Unicamp (1999/2005), foi um dos fundadores e membro do Quilombhoje-Literatura, de 1983 a 1994, e um dos criadores e mantenedores da série Cadernos Negros ${ }^{31}$

Encontramos ainda alguns trabalhos relacionados ao nosso tema, mas que abordaram sobretudo a atuação da Frente Negra Brasileira. Um deles é a Dissertação de Mestrado em História, de Laiana Lannes de Oliveira $^{32}$, que estuda as origens daquela entidade e sua atuação no movimento negro em São Paulo.

A pesquisadora trabalha basicamente com três temas relevantes: relações sociais, representações políticas e o governo Getúlio Vargas. Sua conclusão é que a Frente Negra atuou de forma paradoxal, pois era símbolo de um movimento negro institucionalizado mas tinha como base e influência política teorias consideradas autoritárias, antidemocráticas, oficialistas e fascistas.

À primeira vista, lhe parece contraditório uma organização reivindicatória formada por negros - um grupo "agredido", forçado ao trabalho e vítima do cativeiro - defender o autoritarismo, a desigualdade de direitos e teorias políticas baseadas no racismo. Porém, no decorrer de sua análise, a autora considera que as ações da Frente foram relevantes, sensatas,

\footnotetext{
${ }^{30}$ SILVA, Luiz (CUTI). ...E disse o velho militante José Correia Leite. 19a . ed. São Paulo: Noovha América, 2007.

${ }^{31}$ Criada em 1978, a série Cadernos Negros reúne contos e poemas escritos por autores negros e voltados principalmente para a comunidade afrobrasileira. A temática é direcionada a temas como a questão racial, a resistência negra, a família e a negritude. O grupo editorial Quilombhoje se encarrega da organização, editoração, lançamento e distribuição. A publicação é anual e já foram lançadas 31 edições desde sua criação.

32 OLIVEIRA, Laiana Lannes de. A Frente Negra Brasileira: política e questão racial nos anos 1930. Dissertação de Mestrado em História Política. Orientadora: Marilena Rosa Nogueira da Silva. Universidade do Estado do Rio de Janeiro/Instituto de Filosofia e Ciências Sociais. Rio de Janeiro, 2002.
} 
e os rumos, tomados à luz do contexto político da época sendo, portanto, fruto de seu tempo ${ }^{33}$. Suas conclusões serão comentadas posteriormente. Por ora, contentamo-nos em relatá-las.

Outro estudo interessante é a também Dissertação de Mestrado em História de André Côrtes de Oliveira $^{34}$, sobre a construção discursiva da identidade negra através das páginas do jornal A Voz da Raça. Sua análise do movimento se apoia na formação da "Gente Negra Nacional", nome pelo qual se designava uma "identidade fechada e enraizada em conceitos metafísicos de raça e nação organizados por uma concepção orgânica, eugênica e religiosa da sociedade" $" 35$. Em outras palavras, pode-se dizer que encarnava uma ideia de unidade da "raça" negra que consta no próprio estatuto da Frente Negra, em seu artigo $1^{\circ}$.

$\mathrm{Na}$ maior parte do estudo, André Oliveira trabalha com a construção de uma identidade na Frente Negra Brasileira, como já foi mencionado. Para ele, o discurso encontrado nas páginas de $A$ Voz da Raça era "raciológico e nacionalista, demarcando e localizando os frentenegrinos no espaço e no tempo, construindo para eles uma legitimidade história e biológica de pertencimento à nação que os havia sistematicamente excluído"36.

O pesquisador também discute a presença do fascismo na FNB como reflexo de uma época em que dificilmente se poderia fugir à influência das ideias reinantes.

Por fim, ao encampar a articulação entre raça e nação dentro de uma concepção orgânica de caráter fascista e eugênico da sociedade, considera que o negro deveria seguir o exemplo de seus antepassados, isto é, assumindo a luta e a reivindicação de forma mais radical e aberta, colocando sua vida a serviço da pátria. Para isso, teria que acabar com as divisões internas entre os "irmãos de cor". ${ }^{37}$

Durante o tempo em que fizemos nossa pesquisa para a presente Dissertação, surgiram também várias outras sobre a imprensa negra. Ana Flávia Magalhães Pinto ${ }^{38}$, por exemplo, trabalha com o surgimento dos jornais negros no século XIX em meio à vigência do sistema escravista. Os escolhidos são $O$ Homem de Cor, fundado em 1833 e considerado o primeiro

\footnotetext{
${ }^{33}$ OLIVEIRA, Laiana Lannes de. Op.cit., pp.91-94.

${ }^{34}$ OLIVEIRA, André Côrtes de. "Quem é a "Gente Negra Nacional?" Frente Negra Brasileira e a Voz da Raça (1933-1937). Dissertação de Mestrado em História. Orientadora: Célia Maria Marinho de Azevedo. Universidade Estadual de Campinas. 2006

${ }^{35}$ Idem, ibidem, p.3

${ }^{36}$ Idem, ibidem, p. 100

${ }^{37}$ Idem,ibidem, pp.113-115.

${ }^{38}$ PINTO, Ana Flávia Magalhães. De pele escura e tinta preta: a imprensa negra no século XIX (1833-1899). Dissertação de Mestrado. Orientadora: Profa. Dra. Eleonora Zicaria Costa de Brito. Universidade de Brasília, 2006
} 
periódico da imprensa negra nacional, O Homem, surgido em 1876 em Recife, A Pátria, fundado em 1889 em São Paulo e $O$ Exemplo, criado em 1899 na cidade de Porto Alegre.

Apesar de nossos períodos serem distintos, a pesquisadora relata momentos marcantes da história política brasileira, como a abdicação de D. Pedro I, a criação da Guarda Nacional, a Revolta dos Búzios e o próprio surgimento da imprensa brasileira, com a criação do Correio Braziliense e da Gazeta do Rio de Janeiro. A temática principal dos jornais negros se refere às denuncias e combate ao racismo e à discriminação, tanto no Império quanto na República.

A Dissertação de Pedro de Souza $\operatorname{Santos}^{39}$ estuda especificamente a formação de conceitos de educação e cidadania através dos jornais da imprensa negra de São Paulo entre 1915 e 1937. Partindo de breve descrição dos principais jornais, tem por objetivo mostrar a importância conferida à educação como meio de ascensão social e como um "ato de luta política". Segundo o que diz, a educação também se revestia de uma dualidade, pois representava justificativas para a situação de desigualdade, em alguns momentos ${ }^{40}$.

De acordo com a nossa pesquisa, alguns jornais eram partidários dessa ideia, entre eles o Getulino, mas tentaremos discutir a questão mais adiante, oferecendo ao leitor as nossas ponderações.

Rodrigo Miranda ${ }^{41}$ trabalha unicamente com a trajetória do jornal Getulino, de que também trataremos. Após um breve relato sobre a imprensa negra em Campinas, o pesquisador descreve em detalhes a criação do jornal, seus diretores e redatores e quais os principais assuntos abordados nas suas edições. Trata ainda de outros temas relevantes para a população negra, como a miscigenação, representações sobre o mestiço, a questão da África presente nos jornais e aspectos de religiosidade no meio negro.

Os trabalhos até aqui citados foram muito úteis, na medida em que pudemos realizar uma análise comparativa de resultados em relação à nossa pesquisa, já que também utilizamos várias das fontes primárias por eles consultadas.

\footnotetext{
${ }^{39}$ SANTOS, Pedro de Souza. Cidadania e educação dos negros através da imprensa negra em São Paulo (19151937). Dissertação de Mestrado. Orientadora: Maria Ângela Borges Salvadori. Universidade São Francisco, Itatiba, 2007.

${ }^{40}$ Idem, ibidem, pp. 127-129.

${ }^{41}$ MIRANDA, Rodrigo. Um caminho de suor e letras: a militância negra em Campinas e a construção de uma comunidade imaginada nas páginas do Getulino (Campinas, 1923-1926). Dissertação de Mestrado. Orientadora: Célia Maria Marinho de Azevedo. Universidade Estadual de Campinas.
} 
Todavia, os enfoques foram diferentes. Laiana Lannes, por exemplo, aqui citada páginas atrás, trabalha com a trajetória da Frente Negra Brasileira sob a ótica da História Política, enfatizando a influência da crise do liberalismo e o sentimento nacionalista sobre a população negra. A autora ainda se refere à atuação político-eleitoral da entidade e seu caráter oficialista.

André Côrtes também estudou a Frente Negra Brasileira, mas voltou-se para a existência do fascismo dentro dessa organização, colocando as questões reivindicatórias em nível secundário.

O balizamento cronológico do trabalho de Ana Flávia Magalhães é anterior ao nosso, mas serviu para constatarmos que a imprensa negra durante a escravidão já apresentava alguns dos traços que a caracterizaram nas primeiras décadas do século XX.

A pesquisa de Pedro Souza Santos assemelha-se à nossa quanto à recuperação e descrição dos principais jornais negros, mas seu objeto de estudo concentra-se na temática da educação presente nos periódicos.

O trabalho de Rodrigo Miranda foi o único a falar especificamente do Getulino, periódico que abre a segunda fase da imprensa negra em São Paulo e que pretendemos esmiuçar. Teve grande utilidade pois adicionou informações àquelas que possuíamos, além de trazer subsídios fundamentais a respeito da constituição do jornal, da atuação de suas lideranças, do envolvimento com as comunidades negra e branca em Campinas, das estratégias de sobrevivência do jornal e do relacionamento com periódicos de outras cidades.

É importante reiterar o significado da bibliografia até aqui comentada, pois graças a ela, pudemos confrontar e comprovar os dados empíricos que coletamos na Imprensa Negra e assim, encarar mais confiantemente nossas observações.

São Paulo foi, como já dissemos, o locus por nós escolhido para a pesquisa. Daí ser necessário saber como surge o negro na região.

Evidentemente, sua presença remonta a um passado anterior à abolição da escravidão. A professora Suely Robles Reis de Queiroz ${ }^{42}$ buscou demonstrar no entanto, como foi tardia a introdução do escravo negro em São Paulo em relação a outras regiões do país. Seu número

\footnotetext{
${ }^{42}$ QUEIROZ, Suely Robles Reis de. Escravidão negra em São Paulo: um estudo das tensões provocadas pelo escravismo no século XIX. Rio de Janeiro, J. Olympio; Brasília, INL, 1977
} 
começa a crescer a partir do final do século XVIII, com a instalação e o desenvolvimento da grande lavoura de exportação, aumentando continuamente daí para a frente, de modo que, quando ocorre a abolição, São Paulo era talvez a província que mais escravos possuía.

A autora também procurou verificar de que maneira o grupo dominante paulista praticou a escravidão, como se deu a ação senhorial, qual a atuação da mesma ante a massa de cativos e que tipo de relações predominou. Nesse sentido, estudou o comportamento do escravo diante da instituição: de que modo se conduziu, se seria resignado e submisso como descrito nos relatos de estrangeiros e brasileiros à época, ou não.

A vasta documentação colhida através da pesquisa direta em fontes sobretudo manuscritas, transcritas em detalhe ao longo do trabalho, permitiu a conclusão de que o "senhor benévolo" e o "escravo submisso", foram mitos difundidos pela historiografia, afirmação ratificada por Sérgio Buarque de Holanda no Prefácio que antecede a obra.

Um interessante livro sobre o tema é o de Lilia Moritz Schwarcz ${ }^{43}$, que estuda as representações do negro expressas pela imprensa paulistana entre os anos de 1870 e 1900 . Reunindo dados novos e uma nova abordagem, discute tanto a figura do negro em si, quanto, e, principalmente, em relação ao elemento branco.

Segundo Lilia, os jornais da época, entre eles A Província de São Paulo e o Correio Paulistano, colocam suas "verdades" através de inúmeras representações, como o "nós e eles", "o branco e o negro", "a vítima e o vilão", o "são e o degenerado". Aliás, esse é o momento em que o negro, caracterizado até então basicamente como um ser violento e degradado fisicamente, passa a ser representado também como um degenerado moral, visão reforçada pelo pensamento científico racista da época.

Lembra a autora que em função dos jornais começarem a falar da África e de questões "científicas" veiculadas sobre esse continente e seus caracteres hereditários, num momento em que se introduzia em larga escala o imigrante europeu e ao mesmo tempo se buscava impedir a entrada de outras etnias e raças, como a chinesa, por exemplo, também o negro passa a ser tratado como estrangeiro ${ }^{44}$, aliás, "estrangeiro indesejável".

\footnotetext{
${ }^{43}$ SCHWARCZ, Lilia Moritz. op. cit.

${ }^{44}$ SCHWARCZ, Lilia Moritz. op. cit., pp. 249-255
} 
Outro autor que aborda o racismo é Petrônio Domingues ${ }^{45}$, cujo livro soa como um contundente protesto também contra o projeto de "branqueamento" da população descendente de escravos. Conta como se implementou o "racismo à paulistana", quais as propostas para "desnegrecer" o país no século XIX, os discursos antinegro, o "prefere-se branco" das ofertas de emprego, o racismo na administração pública, na polícia, nas instituições de caridade, o mercado de trabalho na Primeira República e a reação da população negra.

Em sua pesquisa, utiliza fontes tais como registros de testes de alfabetização, censos, memórias de descendentes de escravos à imprensa negra, entre outras.

Domingues tem dados muito reveladores sobre o favorecimento do imigrante europeu em relação ao negro discriminado e que apontam para a construção do mito da superioridade intelectual do primeiro. Aliás, no prefácio ao seu livro, o professor Wilson Barbosa Nascimento afirma que "a força do racismo entre patrões e empregados de origem européia é que explica o grau de exclusão do negro no processo de industrialização de São Paulo".

O sexto capítulo do referido livro, intitulado $O$ negro no mundo dos negros, aborda questões pertinentes e contemporâneas àquelas que nos preocupam em nossa pesquisa, revelando como o negro "conquistou um respeitável grau de consciência racial e de organização coletiva" através de um "mundo paralelo materializado pela rede étnica de jornais, clubes, entidades beneficentes, times de futebol, escolas, bolsões ou territórios nos bairros, grupos teatrais, literatura, salões de baile e cordões carnavalescos"46

Já Antonia Aparecida Quintão ${ }^{47}$ busca outro enfoque em seu livro: o funcionamento das irmandades religiosas negras e suas inter-relações com o catolicismo tradicional e ultramontano. Interessa-nos sobretudo o capítulo que trata da constituição das Irmandades de Nossa Senhora do Rosário dos Homens Pretos de São Paulo e Santa Efigênia e Elesbão, do qual nos utilizaremos mais à frente.

A tese de doutorado da antropóloga Regina Pahim Pinto ${ }^{48}$ é inspirada nos movimentos sociais da década de 1980 e tem como questão central a tomada de consciência da diferença étnica para compreender o movimento negro, sobre o qual a referida obra é uma referência

\footnotetext{
${ }^{45}$ DOMINGUES, Petrônio José. Uma história não contada: negro, racismo e branqueamento em São Paulo no pós-abolição. São Paulo: Senac, 2004.

${ }^{46}$ Idem, ibidem, p. 380

${ }^{47}$ QUINTÃO, Antonia Aparecida. Irmandades Negras: outro espaço de luta e resistência (São Paulo: 18701890). São Paulo: Annablume, 2002.

${ }^{48}$ PINTO, Regina Pahim. op.cit.
} 
para pesquisadores. A autora reforça a tese de Florestan Fernandes, segundo a qual a grande massa dos negros não possuía o aparato social necessário para articular suas reivindicações de maneira mais construtiva ${ }^{49}$. Seu texto é importante em vários aspectos, para efeito de comparação com nossa pesquisa empírica. ${ }^{50}$ Para ela, considerar o material contido nos jornais é fundamental, pois estes

\begin{abstract}
(...) se constituíram num importante veículo, por meio dos quais as lideranças negras iniciaram um trabalho de conscientização e mobilização do negro, de valorização de sua identidade e de luta pela sua plena inserção na sociedade. As bandeiras de luta, as campanhas levadas a efeitos por estes jornalistas para conseguir este objetivo e, ainda, as causas pelas quais lutaram ou o seu posicionamento perante os acontecimentos que diziam respeito ao negro e à sociedade em geral constituem um importante documento para aqueles que pretendem entender o movimento negro. ${ }^{51}$
\end{abstract}

Fora dos temas referentes ao negro, utilizamo-nos também do livro de Maria Auxiliadora Guzzo Decca ${ }^{52}$, colhendo dados sobre a realidade operária em São Paulo em período equivalente ao da pesquisa, com o objetivo de comparar os dois grupo étnicos.

Além desse, percorremos obras de viés econômico que nos ajudaram a começar a entender a formação da sociedade brasileira e paulista, bem como as razões da exclusão a que está submetido o negro brasileiro. Entre elas, destacamos a Formação do Brasil Contemporâneo, de Caio Pradro Jr.; Formação Econômica do Brasil, de Celso Furtado; $O$ Escravismo Colonial e A Escravidão Reabilitada, de Jacob Gorender; Repensando o modelo interpretativo de Caio Prado Jr., de Iraci Del Nero Costa; A fórmula do capital escravistamercantil, de Iraci Del Nero Costa e Júlio Pires; A formação econômica e social do Brasil sob nova ótica, de José Flávio Motta; A Industrialização de São Paulo, de Warren Dean; Expansão Cafeeira e Origens da Indústria no Brasil, de Sérgio Silva; e A Revolução de 1930, de Boris Fausto. ${ }^{53}$

Formação do Brasil Contemporâneo, do historiador, geógrafo e escritor Caio Prado Júnior, explica o processo histórico brasileiro através do materialismo histórico, baseado em Marx. Esse modelo interpretativo já havia sido adotado em Evolução Política do Brasil, livro publicado em 1933, que juntamente com Raízes do Brasil, de Sérgio Buarque de Holanda, e Casa-Grande e Senzala, de Gilberto Freyre, revolucionou a historiografia brasileira.

\footnotetext{
${ }^{49}$ Idem, ibidem, pp. 125-126 Apud OLIVEIRA, André Cortês. op. cit., p. 21

${ }^{50}$ Resultados estão descritos no capitulo 2 deste trabalho.

${ }^{51}$ PINTO, Regina Pahim. Op. cit., p. 66

${ }^{52}$ DECCA, Maria Auxiliadora Guzzo. A Vida fora das fábricas: cotidiano Operário em São Paulo (1920-1934). São Paulo: Paz e Terra, 1987.

${ }^{53}$ Detalhes serão informados na parte do trabalho reservada à Bibliografia.
} 
O "sentido da colonização" em Caio Prado Jr. foi o direcionamento da produção colonial para o mercado externo, composto pelo fornecimento de produtos tropicais e metais preciosos para o mercado europeu. Essa será a temática da colonização e da formação da sociedade colonial brasileira. $\mathrm{O}$ autor visualizou, a partir da realidade do Brasil nas primeiras décadas do século XX, os efeitos da dependência colonial em relação ao mercado externo. A vida material na colônia, evidenciada pela grande lavoura, a monocultura e o trabalho escravo, determinavam a situação econômica, social e política da atualidade. O mercado interno e outras atividades voltadas para o consumo de subsistência seriam considerados elementos acessórios.

Esse "sentido" levou Caio Prado a chamar o Brasil, assim como outras com a mesma orientação, de "colônia de exploração". Diferia totalmente das "colônias de povoamento", exemplificadas naquelas criadas nos Estados Unidos. Também o economista Celso Furtado, em Formação Econômica do Brasil, procurou demonstrar os efeitos negativos para o desenvolvimento econômico brasileiro da orientação voltada para o mercado externo baseada no trabalho escravo. Argumenta que a abundância de terras, o fornecimento de mão de obra cativa e a produção extensiva de gêneros agrícolas exportáveis determinaram o atraso técnico na agricultura e, consequentemente, na economia do país. O direcionamento ao mercado externo e a escassa renda monetária limitavam o desenvolvimento do mercado interno, em um processo que trouxe acentuada concentração de renda entre as classes sociais e no âmbito regional, privilegiando o litoral, principalmente nas regiões Sudeste e Sul. Em suma: defendia tenazmente uma produção voltada para o mercado interno, que deveria ser estimulado a fim de reduzir as fortes desigualdades sociais e regionais.

Os professores Iraci Del Nero Costa, José Flávio Motta e Júlio Pires defendem uma abordagem alternativa e complementar ao modelo interpretativo de Caio Prado, que seria a do capital escravista-mercantil. As principais conclusões em relação a essa nova forma de capital e suas consequências seriam as de que a escravidão localizada não é incompatível com o modo de produção capitalista, e sim com o desenvolvimento do mesmo, portanto, seu desaparecimento é dado como certo; que o escravismo é, ao mesmo tempo, produtor de mercadorias e dependente dos mercados internacionais e que os escravistas são capitalistas, ou seja, são a personificação do capital escravista mercantil. Este resgata a ideia de "sentido", porém, não é autônomo como o capital industrial, pois sua existência depende não apenas de uma relação jurídica estranha aos ideais da sociedade burguesa (o escravismo), mas também do capital comercial, proveniente do tráfico de escravos ou do mercado consumidor europeu. 
Acreditamos nessa linha de pensamento no sentido de que o capital escravista mercantil explica mais adequadamente a realidade colonial e o próprio "sentido da colonização". Não o nega, mas qualifica-o, mantendo o paradigma.

Segundo Pires e Costa, o que faltou a Prado foi um elemento de mediação entre a essência da socidade colonial, seus determinantes em última instância (“o sentido”) e a sua aparência (plano fenomênico, ou seja, a complexidade da economia colonial).

Duas obras de Jacob Gorender também são referências sobre o assunto. Em $O$ Escravismo Colonial, propõe que a colônia deva ser entendida segundo as relações de produção configurando um novo modo de produção definido pelo autor como "modo de produção escravista colonial”. A colônia seria autônoma, teria um modo de produção diferenciado, pois o escravismo era a chave do entendimento da dinâmica colonial, e não o capital comercial.

Outra obra de Gorender intitulada A Escravidão Reabilitada contrapõe-se a autores como Gilberto Freyre e Katia Mattoso ${ }^{54}$ entre outros, para quem, no sistema, teria existido menor coação do escravo pelo senhor, traços de patriarcalismo, parternalismo e até mesmo possibilidades para o escravo negociar com o senhor.

Aprofundando a questão relativa ao "modo de produção escravista colonial", considera brutal a escravidão no Brasil. A paz entre senhores e escravos era restrita e relativa e os "benefícios" conseguidos, na verdade representavam migalhas; não se poderia comparar o escravo a um assalariado dentro do regime escravista.

$\mathrm{Na}$ verdade, vista a relação do ponto de vista econômico, apesar dos escravos constituírem "uma corporação temível”, os quatro séculos de escravidão eram justificados na medida que, para o senhor, as vantagens da exploração [do negro] eram superiores às desvantagens do risco de sua rebeldia.

Para entender como se deu o desenvolvimento da indústria em São Paulo no período correspondente à nossa pesquisa, tendo em vista estabelecer um parâmetro entre o cenário de urbanização e modernidade e a situação de exclusão da população negra na capital paulista, recorremos aos livros de Warren Dean, Sérgio Silva e Boris Fausto.

\footnotetext{
${ }^{54}$ Ver FREYRE, Gilberto. Casa Grande e Senzala. São Paulo: Global, 2003; MATTOSO, Katia Mattoso de Queirós. Ser Escravo no Brasil. São Paulo: Brasiliense, 1990.
} 
O historiador norte-americano, com A Industrialização de São Paulo, já aqui citada, faz uma análise do processo em São Paulo a partir do final do século XIX, quando a produção cafeeira atingia seu apogeu, estendendo seu domínio além fronteiras do Estado, desenvolvendo o transporte ferroviário, estimulando a imigração européia e abrindo caminho para a criação de fábricas.

O desenvolvimento industrial de São Paulo e do Brasil também foi estudado por Sérgio Silva em Expansão Cafeeira e Origens da Indústria no Brasil. O economista trabalha a forma como a indústria nasce das próprias contradições do desenvolvimento capitalista cujo centro é a expansão cafeeira e busca fornecer elementos necessários ao entendimento das formas específicas da reprodução do capital industrial determinadas pela posição dominante do capital cafeeiro na economia brasileira dentro do contexto econômico mundial. Esse capital proporcionou ao Brasil, nas palavras do autor, "saltar etapas" no processo de acumulação interna, importando equipamentos mais modernos e adotando técnicas mais avançadas para garantir uma rentabilidade mais elevada. $\mathrm{O}$ país passava, assim, diretamente à grande indústria, sem atrasar-se em etapas anteriores no desenvolvimento do capitalismo. Doutro lado, os efeitos desse capitalismo acelerado também cobraram sua fatura no aspecto social e de desenvolvimento urbano.

A originalidade das considerações de Sérgio Silva está no fato de que, enquanto na Europa o capital industrial proveio do mercantil, em São Paulo, a indústria surge do capital agrícola.

O período de consolidação da hegemonia de São Paulo dentro do cenário econômico e político brasileiro também é um dos temas de Boris Fausto em A Revolução de 1930: História e Historiografia. O episódio revolucionário expressa, além da decadência da burguesia do café, a necessidade de um reajuste na estrutura precária do país, dependente até então de um único gênero de exportação. Pouco antes, na década de 1920, o tenentismo havia se tornado um núcleo importante de ataque ao predomínio das elites do café, e mesmo sendo considerado um movimento inicialmente isolado, estaria à frente das outras oposições regionais ao iniciar a luta por mudanças, em 1922.

$\mathrm{O}$ agravamento das tensões durante as primeiras duas décadas do século $\mathrm{XX}$, as particularidades das eleições de 1930 e a crise econômica mundial abririam caminho para a revolução vitoriosa, porém caracterizada por um vazio de poder, já que se constituía à base do colapso político da burguesia do café e da incapacidade dos demais setores da sociedade em 
assumi-lo. Os posteriores acontecimentos da década de 1930, como a Revolução de 32, a Ação Integralista, a liquidação do tenentismo sob forma autônoma de protesto, a Aliança Nacional Libertadora e a tentativa de insurreição de 1935 dariam às Forças Armadas o papel de sustentáculo de um Estado que se consolidava de modo diferente do que houvera até então.

Cabe lembrar que certamente essa historiografia acima comentada, à qual virá acrescentar-se nossa modesta pesquisa, será grandemente ampliada com o recente interesse despertado no meio acadêmico pela História da África e de seus descendentes, após a aprovação da lei que institui a obrigatoriedade do ensino da mesma. Os artigos adicionados à Lei de Diretrizes e Bases da Educação revelam a missão dos educadores não só no sentido de conhecerem aquele continente mas também a história do negro no Brasil:

\footnotetext{
Art. 26-A. Nos estabelecimentos de ensino fundamental e médio, oficiais e particulares, torna-se obrigatório o ensino sobre História e Cultura Afro-Brasileira. $\S 1^{\circ} \mathrm{O}$ conteúdo programático a que se refere o caput deste artigo incluirá o estudo da História da África e dos Africanos, a luta dos negros no Brasil, a cultura negra brasileira e o negro na formação da sociedade nacional, resgatando a contribuição do povo negro nas áreas social, econômica e política pertinentes à História do Brasil.

$\S 2^{\circ}$ Os conteúdos referentes à História e Cultura Afro-Brasileira serão ministrados no âmbito de todo o currículo escolar, em especial nas áreas de Educação Artística e de Literatura e História Brasileiras.

$\S 3^{\circ}$ (VETADO)

Art. 79-A. (VETADO)

Art. 79-B. O calendário escolar incluirá o dia 20 de novembro como 'Dia Nacional da Consciência Negra'. ${ }^{55}$ (grifo nosso)
}

Divulgar trabalhos sobre a imprensa negra significa certamente resgatar uma parte importante da história dos afro-descendentes, pois possibilita conhecer o discurso dos próprios atores que representaram "a luta dos negros no Brasil", conforme menciona a lei. Os jornais são fontes documentais que permitem, por exemplo, análises rigorosas para compor planos de aula, por exemplo, além de outras finalidades. Lá estão poemas, anúncios, costumes, anseios e opiniões de membros da comunidade negra, que buscaram através da exaltação de valores, a busca de sua identidade. Entendendo o passado, poderemos passar às gerações futuras uma ideia mais adequada e consistente sobre a representatividade dos grupos étnicos que construíram o Brasil, evitando assim a propagação de representações equivocadas sobre os mesmos.

\footnotetext{
55 “Lei 10.639, de 9 de janeiro de 2003, que altera a Lei no 9.394, de 20 de dezembro de 1996, que estabelece as diretrizes e bases da educação nacional (...)"
} 
Pode-se pensar também que o Brasil atravessa um momento importante de sua história, ao tentar consolidar-se como significativo membro do cenário político e econômico mundial. Em uma realidade globalizada, o país deve preparar-se para entender e saber lidar com a diversidade, o que supõe, entre outras ações, o combate ao racismo, ao preconceito e à discriminação. Não é apenas um interesse social, mas também econômico.

No entanto, cabe lembrar que, como já foi visto aqui, a historiografia relaciona trabalhos que analisaram sobretudo a situação dos negros após a abolição, mas poucos focalizaram o discurso anterior dos mesmos. A maioria das pesquisas foi elaborada sob o prisma da Sociologia ou Antropologia, enfatizando a questão do racismo, do branqueamento ou do eugenismo. A própria imprensa negra foi, durante muito tempo, relegada a um papel secundário em termos de importância cultural, e prova disso é que tanto Nelson Werneck Sodré $^{56}$ quanto Paulo Duarte ${ }^{57}$, por exemplo, não fazem nenhuma menção a jornais negros em suas obras.

As principais referências em relação à imprensa negra ainda são os trabalhos, já comentados, de Roger Bastide e Miriam Nicolau Ferrara. Entre eles, um hiato de aproximadamente três décadas.

O sociólogo tentou entender a "psicologia afrobrasileira",58, ao passo que Miriam Nicolau procurou descrever a origem, estrutura, dinâmica de funcionamento e evolução dos jornais, apontando as principais reivindicações da comunidade afrodescendente. Porém, parece-nos que Ferrara não se aprofunda nas discussões sobre a exclusão do negro na cidade de São Paulo, limitando-se a classificá-lo dentro de um "grupo minoritário na sociedade brasileira, que sofreu a influência da ideologia dominante",59.

Diante disso, pretendemos buscar algo novo sobre a documentação que envolve o negro na Primeira República em São Paulo, com seus principais atores à frente e como pano de fundo uma cidade que representou, mais do que qualquer outra, no Brasil, os ideais de progresso, riqueza e urbanização, aliados a um crescimento acelerado e desordenado, responsável em muitos aspectos pelo estado de pauperização da população negra.

\footnotetext{
${ }^{56}$ SODRÉ, Nelson Werneck. História da Imprensa no Brasil. $1^{\text {a }}$ edição. São Paulo: Civilização Brasileira, 1966.

${ }^{57}$ DUARTE, Paulo. História da Imprensa em São Paulo. Escola de Comunicações e Artes. Universidade de São Paulo, 1972

${ }^{58}$ BASTIDE, Roger. A imprensa negra...p.50.

${ }^{59}$ FERRARA, Miriam. op. cit., p.40. Uma inovação do trabalho da autora é um breve estudo sobre a presença das discussões a respeito da África nos jornais negros, mas essa temática escapa ao conteúdo de nosso trabalho.
} 
Descrever os periódicos e suas características é parte importante de qualquer trabalho que lide com esse tipo de fontes. No entanto, vamos tentar ir além, destacando a atuação dos redatores na elaboração dos editoriais e sua influência junto à comunidade negra, visto que já possuíam a trajetória no meio jornalístico e associativo da raça.

Outro ponto na busca de diferenças a serem destacadas é que não nos fixamos somente na atuação dos jornais dentro do balizamento cronológico por nós proposto. Recorremos às pesquisas de Antonia Aparecida Quintão e Ana Flávia Magalhães Pinto para demonstrar que o espírito de luta presente na imprensa negra já se fazia sentir desde o estabelecimento das primeiras irmandades do século XVIII e na atuação dos periódicos negros oitocentistas. Para Miriam Nicolau Ferrara, “a imprensa negra manifesta em 1915 suas primeiras reivindicações" 60 , mas cabe analisar a afirmação mais detalhadamente, o que será feito no decorrer da Dissertação.

Outro objetivo importante desta pesquisa é mostrar que, a par da conjuntura nacional, os jornais negros se enfraqueceram por entregar-se a disputas ideológicas.

Por último, mas prioritariamente importante, cabe lembrar que a historiografia comentada páginas atrás tratou dos temas contidos nos cinco capítulos por nós formulados, mas pretendemos explorar de forma mais detalhada a repercussão na Imprensa Negra das questões internas do movimento negro, da forma de atuação de suas lideranças e a capacidade de conseguir simpatizantes para a sua causa. Rupturas e divergências diversas foram noticiadas pelos jornais, o que nos levou a tentar demonstrar quando e porque aconteceram. Várias delas não foram analisadas pela historiografia e provavelmente contribuíram para desarticular as tentativas de obtenção de uma identidade étnica e outros avanços.

Nossa base documental fundamentou-se principalmente em fontes primárias, que são os jornais da imprensa negra. Os livros anteriormente mencionados e comentados também complementaram e embasaram a pesquisa. Ao todo, foram consultados 97 exemplares publicados entre 1915 e 1937, abrigados em quatro locais:

1- Instituto de Estudos Brasileiros da Universidade de São Paulo - IEB, cujo acervo foi doado pela professora Miriam Nicolau Ferrara e pode ser consultado através da transcrição de trechos dos jornais;

\footnotetext{
${ }^{60}$ FERRARA, Miriam. Op. cit., p.195
} 
2- Biblioteca Municipal Mário de Andrade, onde foi possível a transcrição de alguns períodicos;

3- Arquivo do Estado de São Paulo, que disponibilizou a transcrição de alguns jornais e a digitalização de outros; e

4- Arquivos do CEDAP - Centro de Apoio à Documentação e Pesquisa da UnespAssis, em que obtivemos informações sobre os jornais negros através de catálogo digitalizado.

Os trechos e citações dos jornais foram organizados por título do periódico, data de publicação, número da edição e título da matéria ou artigo, quando disponível. Elaboramos uma sequência considerando os acontecimentos históricos mais relevantes, com a finalidade de conduzir a narrativa de forma cronológica e inserindo os fatos significativos ocorridos na imprensa negra no contex to histórico de São Paulo.

Considerando que podem existir insuficiências na análise das fontes, como imprecisões causadas por lapso de memória de depoentes a outros estudiosos, cruzamos as informações prestadas, com as mesmas citações e acontecimentos em outras obras e fontes a fim de evitar discrepâncias no resultado final do trabalho.

Assistimos a alguns documentários que tratam a temática do negro no Brasil, entre eles Preto e Branco, Encontros com Milton Santos, A Negação do Brasil e Abolição. O propósito é entender como o país enxerga atualmente a questão racial, o racismo, a possibilidade de ascensão social e a validade das ações afirmativas. Da mesma forma como expusemos através de estudos sócio-econômicos o estado de exclusão do negro ainda vigente no país, gostaríamos de entender melhor como ele enxerga a si e à sociedade brasileira atualmente.

Mas nossa pesquisa perscruta o passado para entender o presente. Por isso, a partir de uma imprensa negra, tentaremos mostrar ao leitor que papel teve ela em São Paulo, no sentido de valorizar o negro em uma época de grandes transformações não só para a população da capital paulista como também para a sociedade brasileira.

Nesse sentido, estabelecemos cinco capítulos. O primeiro, Raízes da Imprensa Negra: a exclusão social, tratará do negro na sociedade brasileira enquanto escravo, fato que determinou a sua exclusão por muito tempo, como se poderá ver em sua trajetória no período 
pós-abolição. No entanto, mesmo nesse período ele lutou contra a sua condição de inúmeras formas, como procuraremos mostrar.

O segundo capítulo, Primeiras reações coletivas à exclusão: irmandades e outras associações, destaca a necessidade dos negros em associarem-se e suas iniciativas. Serão vistas as primeiras associações, suas origens e atuação em São Paulo.

O terceiro capítulo, Novas reações coletivas à exclusão: os primeiros jornais, trata o aparecimento dos primeiros jornais, suas características e objetivos, entre o surgimento de $O$ Menelik e o final da primeira fase da imprensa negra, com o Kosmos, segundo nossa periodização.

O quarto capítulo, Evolução da Imprensa Negra no quadro histórico paulista, é constituído de uma ampla revisão dos editais e notícias da imprensa negra paulista com destaque especial para o aparecimento do Getulino, de Lino Guedes, de O Clarim da Alvorada, de José Correia Leite e Jayme de Aguiar e de $A$ Voz da Raça, o periódico oficial para divulgação das ideias e noticias da Frente Negra Brasileira, criada pelos irmãos Arlindo e Isaltino Veiga Santos. Tudo isso se passou em um contexto econômico-político-social que inclui a Semana de Arte Moderna, a Revolução Tenentista, a Revolução de 1930, a Revolução Constitucionalista de 1932 e a implantação do Estado Novo, em 1937, acontecimentos que se refletirão na atuação dos personagens de que tratamos.

O último capítulo, As disputas entre as lideranças da Imprensa Negra e suas conseqüências, mostrará as disputas ideológicas que a nosso ver serão decisivas para a mudança de sentido da Imprensa Negra nas décadas seguintes ao Estado Novo e as principais razões para a decadência do aspecto reivindicatório dos jornais. 


\section{Capítulo 1 - Raízes da Imprensa Negra: a exclusão social}

É impossível pensar em pesquisas e debates sobre a memória do negro, sua atuação, seu papel na sociedade brasileira, sem levar em conta o fato de que os quase quatro séculos de escravidão alteraram profundamente sua identidade, seu corpo e os valores culturais forjados no continenente africano.

A escravidão negra no Brasil surgiu concomitantemente à constatação de que a mão de obra indígena dificilmente atenderia aos interesses econômicos dos colonos e, naturalmente, da metrópole portuguesa ${ }^{61}$.

Ao longo de mais de 350 anos, "o suprimento de trabalho escravo foi condição imperativa para a expansão do sistema econômico instalado com a grande lavoura, que visava a um mercado externo" ${ }^{\circ 2}$. Utilizado principalmente na atividade açucareira do Nordeste e Rio de Janeiro, e também em outras produções agrícolas de exportação como as do tabaco e do algodão, por exemplo, o escravo negro foi muito importante em São Paulo, mas de presença tardia em relação a outras áres do país.

Estudos já realizados demonstraram a verdade dessa afirmação. Até a segunda metade do século XVIII, portanto em um período de trezentos anos aproximadamente, o índio superava em muito o negro escravo no seio de uma economia baseada em lavoura de subsistência, na criação de gado e no apresamento.

Contudo, no final do século XVIII, com o esgotamento do ciclo da mineração na Colônia e os interesses voltados novamente para a agricultura, as melhorias realizadas nas vias de transporte da Capitania de São Paulo, sobretudo no Caminho do Mar, permitem-lhe integrar-se em uma economia de mercado através da lavoura de cana. Essa atividade favorece a fixação daqueles que anteriormente apenas transitavam por ali em direção às regiões do ouro de Minas Gerais, Mato Grosso e Goiás.

O aumento do número de escravos foi realmente grande em São Paulo durante o
ciclo da cana. Basta confrontarem-se as cifras correspondentes aos anos de 1813 e
1836. São momentos bastante sugestivos, pois o primeiro corresponde à fase do
desenvolvimento da lavoura canavieira e o segundo quase ao seu apogeu. Em 1813
havia para uma população livre de 160.969 habitantes, 48.245 escravos. Em 1836 a
população livre era de 238.969 e a escrava de 86.933 habitantes. Isso mostra que de

${ }^{61}$ Ver MONTEIRO, John Manuel. Negros da Terra: índios e bandeirantes nas origens de São Paulo. São Paulo: Companhiadas Letras, 1994; GOULART , Maurício. A escravidão africana no Brasil: das origens à extinção do tráfico. São Paulo: Alfa-Ômega,1975.

${ }^{62}$ QUEIROZ, Suely Robles Reis de. Escravidão Negra...p. 41. 
1813 a 1836 a população livre aumentou $44.7 \%$ e a escrava de $80.1 \%$. Esse acréscimo de população de escravos deve-se ao desenvolvimento da lavoura canavieira, embora não se deva esquecer que em 1836, o café, principalmente no Vale do Paraíba, já exigia certo número de escravos. ${ }^{63}$

A importação crescente de negros é multiplicada com o advento do café, responsável pela riqueza também crescente da já então Província de São Paulo.

O número de escravos correspondia a $23 \%$ e $27 \%$ da população total da Província de São Paulo em 1813 e 1836, respectivamente. Com 117.238 escravos para uma população livre de de 294.612, essa proporção se mantém em $28 \%$ em 1854. Nesse momento, o café substitui a cana de modo extremamente vantajoso para os fazendeiros.

Nas palavras de Florestan Fernandes, "a evolução da escravidão em São Paulo apresenta algumas peculiaridades, porque a expansão da 'grande lavoura' nesta Província coincide com o período em que se inicia e se processa o colapso do sistema escravo no Brasil. A renovação ilimitada do 'braço negro’ torna-se praticamente impossível desde a cessação do tráfico ${ }^{64,}$.

Não há dúvida, portanto, que o escravo negro assumiu importância fundamental como elemento propulsor da economia paulista em sua transição de um modelo agrícola de subsistência para um dos pólos econômicos mais desenvolvidos do país. Isto porque, apesar da cessação do tráfico externo, São Paulo começa a importar vorazmente os cativos de áreas em dificuldades econômicas.

Evidentemente, a manutenção de um modelo exportador de proporções significativas exige toda uma estrutura jurídica para garanti-lo. A legislação paulista seguia a das demais regiões escravistas, sendo altamente coercitiva e repressiva. Uma postura de Taubaté de 1873 chegava a proibir, por exemplo, o batuque, por temer a formação desses ajuntamentos ${ }^{65}$.

Em São Paulo, a política discriminatória é bastante clara:

Art. 46 - São proibidos na cidade os bailes de pretos (de qualquer natureza), salvo com licença de autoridade policial: multa de $10 \$$ e três dias de prisão.

\footnotetext{
${ }^{63}$ PETRONE, Maria Teresa S. A lavoura canavieira em São Paulo. São Paulo, 1968. pp.110-111 apud QUEIROZ, Suely Robles, op. cit., p.22

${ }^{64}$ BASTIDE, Roger. FERNANDES, Florestan. Brancos e Negros em São Paulo. 2a. edição. São Paulo: Companhia Editora Nacional. 1959, p. 38

${ }^{65}$ Cf. Fernando Mendes de Almeida, Os feiticeiros, IN: RAMSP, Vol. 56, p. 85, apud QUEIROZ, Suely. op. cit., p. 52 .
} 
Art. 58 - É proibido ao negociante de molhados consentir em seus negócios pretos e cativos, sem que estejam comprando. O negociante sofrerá multa de $5 \$$ e o escravo ou pessoa suspeita irá para a cadeia.

Art. 62 - São proibidas as cantorias e danças de pretos se não pagarem os chefes de tais divertimentos o imposto de $10 \$$.

Art. 64 - Ficam proibidas as cantorias e danças conhecidas vulgarmente por batuques sem preceder licença da autoridade competente $(. . .)^{66}$

O conhecimento dessas proibições torna-se repleto de significação e é fundamental para entender-se o surgimento das associações e das congregações de negros em São Paulo, dos bailes e dos grêmios recreativos que deram origem aos principais jornais da imprensa negra, como se poderá ver em capítulos posteriores do presente trabalho.

Dado o quadro geral de opressão e controle social sobre o negro pelo branco, podemos entender como os corolários da escravidão e seus efeitos nefastos sobre o cativo foram fundamentais para o estado de exclusão em que vivia o elemento negro em São Paulo tanto antes como depois da abolição. A escravidão aprofundou as diferenças entre o branco e negro, na medida em que atestava oficialmente a superioridade do primeiro em relação ao segundo, não proporcionando a este elementos de contestação e, consequentemente, despojando-o de qualquer possibilidade e capacidade de consciência.

Após 1888, mesmo sendo o elemento responsável pelo salto econômico experimentado por São Paulo a partir do final do século XVIII, o negro, embora livre da escravidão, passa a ser discriminado e desvalorizado pelo branco.

Apesar de seu caráter humanitário, o abolicionismo não foi capaz de dar amparo técnico, psicológico e econômico ao ex-escravo ou ao liberto. No auge da transição, o que mais preocupava as classes dominantes, compostas principalmente por fazendeiros, eram as formas de indenização que podiam ser oferecidas.

A tendência inicial dos debates posteriores à aprovação da Lei foi a de reparar os
prejuízos causados aos fazendeiros com a perda de seus escravos. Em maio,
imediatamente após a Abolição, dois projetos foram apresentados na Câmara dos
Deputados. O primeiro, relativo à extinção das dívidas fiscais provenientes da
transmissão da propriedade escrava, de autoria de Rodrigues Peixoto, propunha o
cancelamento das dívidas existentes, posto que a escravidão não mais existia. O
segundo, de autoria de Coelho Rodrigues, propunha a indenização aos fazendeiros
pela perda da propriedade sobre os escravos. Ambos os projetos não tiveram
qualquer impacto político, além do significado imediato de se tentar, de alguma
maneira, reparar eventuais perdas financeiras sofridas pelos fazendeiros com a
Abolição. Não obstante, durante os meses de junho e julho, a posição dos

${ }^{66}$ Coleção de leis e posturas municipais promulgadas pela Assembléia Legislativa Provincial de São Paulo (CLMSP) - São Paulo: Tip. Correio Paulistano, 1885-1887), pp. 132-291 apud DOMINGUES, Petrônio José. Uma história não contada...p. 36 
fazendeiros tornou-se mais consistente em termos políticos. O objetivo passou a ser o de tornar os fazendeiros credores da condução e do epílogo do processo de desescravização, tal como ele havia ocorrido. ${ }^{67}$

Nas palavras de Florestan Fernandes, "a instituição da escravidão não seria possível em um país cristão sem a ideia de que o negro fosse inferior e subordinado ao branco" ${ }^{\text {}} 68$. $\mathrm{Na}$ verdade, esse conceito fundamentava o cativeiro, segundo o qual o negro se beneficiaria dele.

Influenciado pelas reflexões iluministas, José Bonifácio escreveu, em 1823, uma Representação à Assembléia Geral Constituinte e Legislativa do Império do Brasil sobre a Escravatura. Num primeiro momento, apresenta a escravidão como o grande problema nacional para, em seguida, considerar e criticar os argumentos convencionais que a justificavam do ponto de vista ético, econômico e jurídico. O trecho a seguir contraria a visão de que o negro era escravizado para sua própria proteção e benefício.

(...) diz que é um ato de caridade trazer escravos d'África, porque assim escapam
êsses desgraçados de serem vítimas de despóticos Régulos; diz igualmente que, se
não viessem êsses escravos, ficariam privados da luz do Evangelho, que todo cristão
deve promover, e espalhar: diz que êsses infelizes mudam de um clima e país
ardente e horrível para outro doce, fértil e ameno; diz por fim, que devendo os
criminosos e prisioneiros de guerra serem mortos imediatamente pelos seus bárbaros
costumes, é um favor, que se lhes faz, comprá-los, para lhes conservar a vida, ainda
que seja em cativeiro. Homens perversos e insensatos! ${ }^{69}$

Embora sua preocupação fosse com o branqueamento da população, havia muito de verdade no que dizia "O Patriarca da Independência". No entanto, apesar do grande prestígio de que gozava, suas palavras cairam no vazio, e essa omissão foi respaldada por requisitos econômicos, jurídicos e políticos que Florestan Fernandes chamou de "ordem social competitiva" ${ }^{, 70}$ : uma estrutura montada para atender os anseios das classes dominantes.

Na verdade, entendemos que a implementação dos planos dessas elites que visavam a inclusão do país na rota da modernidade e do desenvolvimento econômico segundo padrões europeus, somente seria possível se existisse uma estrutura de mercado capitalista constituída pela estruturação do trabalho e das relações econômicas. Essa existência era dificultada pela própria degradação do trabalho criada pela escravidão.

\footnotetext{
${ }^{67}$ GEBARA, Ademir. Evolução da Legislação Civil e o Problema da Indenização. IN: SZMRECSÁNYI, Tamás e LAPA, José Roberto do Amaral Lapa (org). História Econômica da Independência e do Império. Coletâna de Textos I Congresso Brasileiro de História Econômica. São Paulo: USP, setembro de 1993, p.96.

${ }^{68}$ FERNANDES, Florestan. O Negro no mundo dos brancos... p. 42.

${ }^{69}$ IN: SANTOS, Gislene Aparecida dos. A invenção do "ser negro”. São Paulo: Pallas, 2002, pp. 65-80 e MOURA, Clóvis. Dicionário da Escravidão Negra no Brasil. São Paulo: Edusp, 2004, pp. 36-39.

${ }^{70}$ Sobre ordem social competitiva, ver também FERNANDES, Florestan. A revolução burguesa no Brasil. Ensaio de Interpretação Sociológica. Rio de Janeiro: Zahar, 1976.
} 
Em termos de Brasil, São Paulo constituía uma das poucas áreas que apresentavam um "pólo econômico básico": senhores de terras e fazendeiros como provedores de produtos tropicais, intermediários para execução de movimentos de exportação e importação, estabelecimento de comerciantes e negociantes locais e estrangeiros, banqueiros e agentes financeiros, alguns profissionais liberais, professores e burocratas, poucos fabricantes e trabalhadores, seja em fábricas, seja como técnicos, artesãos ou operários especializados.

Essa estrutura começou a encorpar-se e a crescer já a partir da supressão do tráfico de escravos e da criação das leis de emancipação. A partir da crise do sistema escravista, ocorreu a modernização do setor urbano, operacionalizada tanto no âmbito econômico quanto político. Nesse sentido, a cidade de São Paulo foi um locus privilegiado para encampar os planos de crescimento das elites.

Basta lembrar o que diz o "brasilianista" Richard Morse:

\begin{abstract}
Em 1890, ...São Paulo já começara a expandir-se em todas as direções, a partir de sua colina central. A este, a baixada do Brás, com sua Estação do Norte e a Hospedaria de Imigrantes, rapidamente se transformava em bairro de pequeno comércio e reduto do operariado. A Estação da Luz ao norte era o centro de atividade, sendo os terrenos aí também ocupados pelas classes mais pobres. O sul e o sudoeste não contavam com o estímulo de uma linha férrea e sua estação terminal, e apenas começavam a sentir a pressão pelo espaço residencial. Mas a noroeste, a zona de chácaras subdivididas de Santa Efigênia e Campos Elíseos claramente denunciava então a cultura e os interesses urbanos da elite em ascensão - tal como a Praça da República, antigo Largo dos Curros, recentemente embelezada. ${ }^{71}$
\end{abstract}

A expansão urbana levou, de um lado, ao crescimento de bairros operários nas zonas industriais que acompanhavam as vias férreas, como Mooca, Brás, Pari, Belém, Lapa, Bom Retiro, Ipiranga, e, de outro, à formação de bairros de elite, como Campos Elíseos, Higienópolis e Avenida Paulista.

Nos bairros populares, as ruas estreitas cortavam os estabelecimentos industriais e as moradias densamente povoadas. Geralmente havia barro nos caminhos, esgoto a céu aberto e bonde na via principal. A falta de saneamento básico no novo cenário industrial propiciava a transmissão de doenças.

A leste, um outro bairro, povoado sobretudo de italianos, estende-se ao longe na planície baixa e contrasta por suas fábricas, suas ruas sujas, seus esgotos lodosos, com as construções elegantes e as chácaras dos bairros ocidentais. Seria urgente drenar o solo e organizar vastos espaços em parques e jardins; mas as construções

\footnotetext{
${ }^{71}$ MORSE, Richard. Formação Histórica de São Paulo: da comunidade à metrópole. São Paulo: Difel, 1970, p. 355.
} 
invadem incessantemente as terras pantanosas e podres de imundícies, onde os córregos se encontram para ir se derramar ao norte do rio Tietê. ${ }^{72}$

Em contraste, "os bairros ricos gozavam de amplas e elegantes avenidas pelas quais desfilavam palacetes cercados de muros, abastecidos pelos serviços públicos: rede de água, esgoto, iluminação e calçamento, além de uma lei que regulamentava a construção e a ocupação de "jardins e arvoredos", 73

Todos os bairros foram vítimas de intensa especulação imobiliária, o que resultou no elevado preço dos terrenos e moradias. O crescimento urbano desordenado e acelerado foi tema de preocupação das autoridades, conforme relatório feito ao governo do Estado em 1891:

\begin{abstract}
Conquanto fundada há mais de 330 anos, S. Paulo é uma cidade nova, cujo aspecto geral assignala-se agora por uma constante renovação das edificações antigas, as quaes desapparecem rapidamente e pelas multiplicadas construções que constituem os bairros novos.

Seguramente duas terças partes da cidade actual é de data muito recente.

Examinada em globo, S. Paulo é uma cidade moderna com todos os defeitos e qualidades inherentes ás cidades que se desenvolvem muito rapidamente. Desigualdade nas edificações e nos arruamentos, desigualdades de nível muito sensíveis, irregularidade nas construções realisadas sem plano premeditado, largas superfícies habitadas sem os indispensáveis melhoramentos reclamados pela hygiene, grandes espaços desocupados ou muito irregularmente utilizados, e a par de tudo isso uma população que triplicou em dez annos, grande movimento, muito commercio, extraordinária valorisação do solo e das edificações e clima naturalmente bom. ${ }^{74}$
\end{abstract}

Lembram os estudiosos que o negro, como escravo ou liberto, tinha uma posição definida dentro da estrutura econômica que, no entanto, foi ameaçada quando se extinguiu o sistema de produção escravista. A partir das três últimas décadas do século XIX, o mercado internacional (entenda-se europeu), forneceu mão de obra imigrante que vinha para o Brasil em busca, geralmente, de melhores oportunidades de trabalho, fosse como trabalhadores rurais e urbanos, comerciantes ou fabricantes. Ao mesmo tempo, famílias brancas começavam a mudar do interior para as grandes cidades. Com trabalhadores nacionais e estrangeiros absorvendo as melhores oportunidades de trabalho, sobretudo nas regiões das fazendas de

72 RÉCLUS, Elisée. Nouvelle Géographie Universelle, tomo 19, Paris, 1894, Hachette, p. 370-1. IN: ANDRADE, Margarida Maria de. Brás, Moóca e Belenzinho: formação e dissolução dos antigos bairros “italianos" além Tamanduateí. Travessia São Paulo. Ano XIII, número 38, setembro-dezembro/2002. p.5.

73 REIS, Nestor Goulart. São Paulo e outras cidades: produção social e degradação dos espaços urbanos. São Paulo: Hucitec, 1994, p.95.

${ }^{74}$ Relatório da Comissão de Saneamento das Várzeas, São Paulo, 1890-1891 (manuscrito na Biblioteca Municipal de São Paulo, datado de 7 de novembro de 1891), pp. 1-2, IN: MORSE, Richard. Formação Histórica de São Paulo..., p. 251. 
café em São Paulo, negros e mulatos formavam um setor amplamente marginal da população e um subproletariado.

Esse quadro se manteve até o final da Primeira Guerra, quando o fluxo migratório começa a inverter-se. A partir da década de 1920, a migração interna será mais importante para o crescimento das grandes cidades do Sul e Sudeste, que já apresentavam desenvolvimento industrial muito superior à média nacional:

A $1^{\text {a }}$. Guerra Mundial interrompeu a onda migratória para cá. Nas décadas de 1920 e 30, afora os japoneses, as contribuições de outras nacionalidades decaem bastante, seja porque a guerra havia reduzido a pressão populacional na Europa, seja porque já não interessava tanto ao agricultor europeu o trabalho nas fazendas de café; e mesmo porque o Brasil, a exemplo dos Estados Unidos, foi se voltando para uma obstrução à imigração através do sistema de quotas. A população nacional ia aumentando gradativamente. Produziam-se modificações de ordem política e econômica que foram favorecendo a implantação de indústrias. As cidades, especialmente Rio de Janeiro e São Paulo, ganhavam impulso. ${ }^{75}$

Tanto trabalhadores estrangeiros como nacionais passam a buscar mais frequentemente as cidades. Alguns do primeiro grupo percebem relativo sucesso, atuando como empresários ou operários mais especializados na indústria em expansão. O movimento migratório interno iria superar a imigração estrangeira de forma acentuada até o fim da Segunda Guerra. ${ }^{76}$

São Paulo, como centro industrial de grande destaque, foi alvo da maior parte do fluxo migratório interno do país. Entre 1900 e 1920, o número de migrantes que vieram para São Paulo correspondia a 1,13\% da população brasileira medida pelos censos daquele período. Nos vinte anos que se seguiram, o percentual aumentou para $11.54 \%$. Um estudo das taxas migratórias confirma esse incremento como o maior entre as demais regiões e amplamente superior à média nacional ${ }^{77}$ :

\footnotetext{
${ }^{75}$ BRAIDO, Jacyr F. As migrações na atualidade brasileira. IN: Migrantes: Êxodo Forçado. Centro de Estudos Migratórios. São Paulo: Edições Paulinas, 1980, p. 16.

${ }^{76}$ Idem, ibidem, pp. 16-19. Ver também BAER, Werner. A economia brasileira.2 ${ }^{\text {a }}$ edição. São Paulo: Nobel, 2003, pp. 349-350.

77 IN: BAER, Werner. op. cit., p.350. Ver também GRAHAM, Douglas H. \& HOLLANDA Filho, Sergio Buarque de. As migrações Inter-regionais e Urbanas e o Crescimento Econômico do Brasil Apud MOURA, Hélio Augusto de (Coord). Migração Interna: textos selecionados. Fortaleza: Banco do Nordeste do Brasil e Estudo Técnico de Estatísticas Econômicas do Nordeste-ETENE, pp.740-741
} 


\begin{tabular}{|c|c|c|c|c|c|c|}
\hline \multicolumn{7}{|l|}{ Taxas nacionais } \\
\hline \multicolumn{2}{|c|}{ Periodos de 10 anos entre censos } & \multicolumn{2}{|c|}{ Taxa } & \multicolumn{2}{|l|}{20 anos } & Taxa \\
\hline $1890-1900$ & & \multicolumn{2}{|c|}{2,97} & \multicolumn{2}{|l|}{$1900-1920$} & 3,79 \\
\hline $1940-1950$ & & \multicolumn{2}{|c|}{2,94} & \multicolumn{2}{|l|}{$1920-1940$} & 4,99 \\
\hline $1950-1960$ & & \multicolumn{2}{|c|}{5,51} & \multicolumn{2}{|l|}{-} & - \\
\hline $1960-1970$ & & \multicolumn{2}{|c|}{4,49} & \multicolumn{2}{|l|}{ - } & - \\
\hline \multicolumn{7}{|l|}{ Taxas regionais* } \\
\hline & $1890-1900$ & $1900-20$ & $1920-40$ & $1940-50$ & $1950-60$ & $1960-70$ \\
\hline Norte & 27,38 & 16,66 & $-13,72$ & $-3,38$ & 0,39 & 2,78 \\
\hline Nordeste & $-1,42$ & $-1,68$ & $-0,84$ & $-2,67$ & $-9,78$ & $-5,08$ \\
\hline Leste & $-0,64$ & $-4,81$ & $-5,37$ & $-3,36$ & $-3,10$ & $-5,57$ \\
\hline Sul & $-0,97$ & 5,24 & 11,73 & 6,07 & 8,25 & 5,61 \\
\hline Sào Paulo & 5,43 & 1,13 & 11,54 & 5,70 & 7,80 & 7,66 \\
\hline Paraná & $-7,47$ & 13,43 & 19,58 & 29,28 & 43,58 & 18,39 \\
\hline Centro-Oeste & 2,64 & 11,88 & 13,37 & 7,27 & 22,52 & 23,22 \\
\hline Goiás & 2,17 & 10,33 & 9,92 & 11,15 & 21,34 & 21,42 \\
\hline Mato Grosso & 3,81 & 15,60 & 21,30 & $-0,55$ & 23,59 & 27,38 \\
\hline
\end{tabular}

* Essa tabela utiliza antigas divisões mactortegionais.

Fonte: GRAHAM, Douglas H. \& MERRICK, Thomas W. "Population and economic growth in Brazil: an interpretation of the long-term trend (1800-2000)", mar./1975, p.49, mimeografado.

O crescimento significativo da migração interna em direção ao Sul e Sudeste beneficiou principalmente São Paulo no suprimento de mão-de-obra para o seu desenvolvimento industrial, mas ao mesmo tempo agravou a situação das camadas menos favorecidas da população, incluindo os próprios migrantes, operários nacionais e estrangeiros e, principalmente negros e mulatos que já formavam uma crescente população de desempregados ou alocados em subempregos.

Um relato de dois negros que viveram nesse período ilustra bem tal situação:

Os negros eram quase tantos quanto os italianos, na época, em São Paulo, [mas] viviam totalmente desintegrados...Os imigrantes - na indústria e comércio. Para o negro sobrava só a tarefa de lavar casas, limpar escritórios, carregar lenhas e outras cargas. Éramos todos subempregados. Via-se muito, na época, negros puxando carrocinhas pela cidade ou fazendo 'ponto' na [rua] Quintino Bocaiúva, com latas e escovões nas mãos, à espera de ser chamado para limpar uma casa aqui, raspar um assoalho ali.

O negro, como se diz na gíria atual, tinha que se virar. Tiveram que criar várias fontes de trabalho, como carregadores, limpadores de quintal, empregados domésticos, carpidores de ruas, lavadores de automóveis, todos empregos que não existiam o negro criou, o próprio engraxate, o vendedor de jornal, o trabalhador em 
pequenos sítios, trabalhos criados para a sua subsistência porque os fazendeiros não aceitavam o trabalho do negro... ${ }^{78}$

No interior, ocupavam-se totalmente na economia de subsistência, com mudança apenas de empregador.

Os europeus não eram a única fonte de trabalho livre disponível para os fazendeiros.
Havia também em São Paulo disponibilidade de populações de negros livres,
brancos e caboclos, em números que excediam a população escrava. Entretanto,
como já vimos, os brasileiros livres relutavam em aceitar emprego nas fazendas de
café ou de cana-de-açúcar. Do mesmo modo que os imigrantes, achavam que os
fazendeiros tendiam a tratar todos os seus empregados como escravos, mesmo os
livres. Aceitar trabalho nas fazendas colocava-os desconfortavelmente próximos à
condição de escravos, especialmente se fosse pardos ou pretos. Em vista disso,
brasileiros e africanos livres preferiam permanecer no setor de subsistência,
cultivando seus próprios pedaços de terra e só aceitando emprego nas fazendas em
base ocasional e esporádica. Mesmo nesses casos, preferiam um tipo de trabalho que
os escravos não faziam, como limpar terra virgem e construir estradas, ambos
trabalhos considerados perigosos demais para os senhores ali arriscarem seus
escravos.

Ou seja, o principal problema enfrentado pelo negro foi a incapacidade da sociedade nacional de criar rapidamente um modelo econômico capaz de absorver a mão-de-obra de exescravos e libertos.

Portanto, pode-se dizer que a Abolição ocorreu em condições altamente espoliativas para os negros. Perderam o único referencial que os associava ativamente à economia e à vida social para transformarem-se em verdadeiros "párias" da cidade ou campo. Em São Paulo, compuseram a maior parte da população dependente nas três primeiras décadas do século XX. Nesse período, eles se juntavam a outras camadas mais pobres da população em seu estado de pauperização, entre elas as classes de trabalhadores que viviam em bairros operários.

No conjunto, a política que as elites no poder e os grupos ascendentes fomentaram revelou-se eficiente no plano restrito do crescimento econômico mais acessível, mas não levou em conta o equilíbrio da sociedade nacional mediante uma ordem multi-racial. Como acentua Florestan Fernandes, "operou-se, pois, num contexto de mudança sócio-econômica relativamente acelerada, uma grande concentração social, regional e racial da renda, do

\footnotetext{
${ }^{78}$ Os jornais dos netos de escravos, Jornal da Tarde (12 jun. 1975), p. 17 IN: Frente Negra Brasileira, 19301937 (trabalho de pesquisa cooperativo não publicado, Pontifícia Universidade Católica de São Paulo, 1985), anexo 2, sem paginação, apud ANDREW, George Reid. op.cit., pp. 113-114

${ }^{79}$ KOWARICK, Lúcio, Trabalho e vadiagem: a origem do trabalho livre no Brasil. São Paulo, 1987, pp. 65-69; Ver também BEIGUELMAN, Paula. Formação do povo no complexo cafeeiro: aspectos políticos. $2^{\mathrm{a}}$. ed., São Paulo, 1977, pp. 105-109; COSTA, Emília Viotti. Da senzala à colônia, 2a . ed., São Paulo, 1982, p. 13 apud ANDREWS, George Reid. Op.cit., pp. 95-96.
} 
prestígio social e do poder. ${ }^{, 80} \mathrm{E}$ talvez possamos dizer que em nenhum outro lugar esse cenário ficou tão claro como em São Paulo.

Comparativamente a outros núcleos urbanos do país, São Paulo pelo fato do escravo negro ter vindo tardiamente não se destacava pela alta proporção de negros e mulatos dentro da população global entre o final do século XIX e as primeiras décadas do século XX. Contudo, favorecido pela produção e exportação de café, com as consequentes urbanização e modernização aceleradas, a par da industrialização, produziu um cenário de prosperidade, no qual ao negro e ao mulato também foi atribuído um papel marginal. Ao final da escravidão, já estavam distribuídos nas ocupações mais indesejáveis do mercado de trabalho, sem conseguirem competir com o imigrante europeu. Essa seleção negativa originou o chamado "serviço de negro": um trabalho bruto, mal remunerado, desprovido de perspectivas de futuro.

Faltou-lhe preparo laboral ou psicológico para ajustar-se às características do trabalho assalariado. $\mathrm{O}$ ex-escravo e mesmo o liberto anteriormente à Abolição interpretaram sua liberdade per si; a autonomia a ser alcançada se opunha às "normas" do trabalho remunerado. Para o negro, vender sua força de trabalho possivelmente equivaleria à sua venda como pessoa, não sendo aceitáveis algumas prerrogativas inerentes a um ambiente de trabalho competitivo, tais como regras, obrigações, índices de produtividade a cumprir. Esse comportamento provocava nos empregadores sentimentos imediatos de intolerância e incompreensão, dada a abundância de mão-de-obra, principalmente a imigrante europeia. $\mathrm{Na}$ opinião de Fernandes, o contratante consideraria o negro como "imprestável" ou "intratável" a partir do momento que estivesse fora do âmbito da escravidão ${ }^{81}$. Antes visto como indispensável dentro da ordem escravista vigente, embora sempre desvalorizado, "suas falhas como pessoa seriam no máximo toleradas ou se esperaria que mudassem ao longo do tempo".

Nesse ambiente de subemprego e despojamento de valores individuais e culturais, cabe especial menção ao papel feminino, que será visto com mais vagar páginas à frente.

No entanto, pode-se adiantar que a mulher negra sempre sofreu dupla discriminação: ser mulher em uma sociedade machista e racista. No escravismo, era trabalhadora forçada. Após a abolição, lhe foram confiados trabalhos braçais, insalubres e pesados e, pelo menos, podia dedicar-se aos serviços domésticos, embora sob ínfima remuneração. No entanto, assumia papel fundamental para a unidade familiar.

\footnotetext{
${ }^{80}$ FERNANDES, Florestan. O negro no mundo dos brancos... p. 31.

${ }^{81}$ FERNANDES, Florestan. O negro no mundo dos brancos....p. 88.
} 
Tal "sorte" não possuía o homem, que, a partir de seu ócio, um produto das circunstâncias como já foi dito, se via exposto a outros tipos de riscos e de exploração, convergindo para um quadro ainda mais agravado de miséria, degradação moral e desorganização da vida social.

O certo é que a exclusão social do negro era evidente e sua condição extremamente desigual em relação ao branco.

Embora amenizada, ainda é vista até os dias de hoje. Bastar ler o que dizem relatórios recentes como aqueles elaborados pelo DIEESE e IPEA para comprovar a afirmação. Em Escolaridade e Trabalho: desafios para a população negra nos mercados de trabalho metropolitanos, preparado pelo DIEESE - Departamento Intersindical de Estatística e Estudos Sócio-Econômicos ${ }^{82}$, a situação da população economicamente ativa (PEA) negra é bastante desfavorável quanto à educação. Entre agosto de 2006 e junho de 2007 foram pesquisadas cinco regiões metropolitanas e o Distrito Federal, constatando-se que é grande a concentração de negros nas faixas de menor escolaridade (do analfabeto até o ensino médio incompleto).

Tal quadro se inverte nos níveis mais elevados de instrução (médio completo a superior completo). A constatatação foi de que negros teriam maior dificuldade em continuar os estudos, o que impediria seu progresso profissional e consolidaria as bases da discriminação racial.

Em todas as regiões pesquisadas a proporção de negros com escolaridade igual ou inferior ao ensino médio incompleto aproxima-se da faixa dos $50 \%$ ou mais. Em Salvador, 47,9\% dos negros têm até o ensino médio incompleto; no Distrito Federal, 49,3\%; no Recife, 55,4\%; em Belo Horizonte, 57,2\%; em São Paulo, 60,3\%; e em Porto Alegre, 64,9\%. Para os não-negros, porém, a parcela da população nas faixas até o ensino médio incompleto era bem menor, variando de $21,3 \%$ em Salvador a 46,9\%, em Porto Alegre.

Tal parecer pode ser analisado através do gráfico 1.

\footnotetext{
${ }^{82}$ DIEESE, Caderno Estudos e Pesquisas, ano 3, número 37, novembro de 2007.
} 


\section{GRÁFICO 1}

Percentagem da PEA com até o ensino médio incompleto

Regiões Metropolitanas e Distrito Federal - agosto/2006-julho/2007

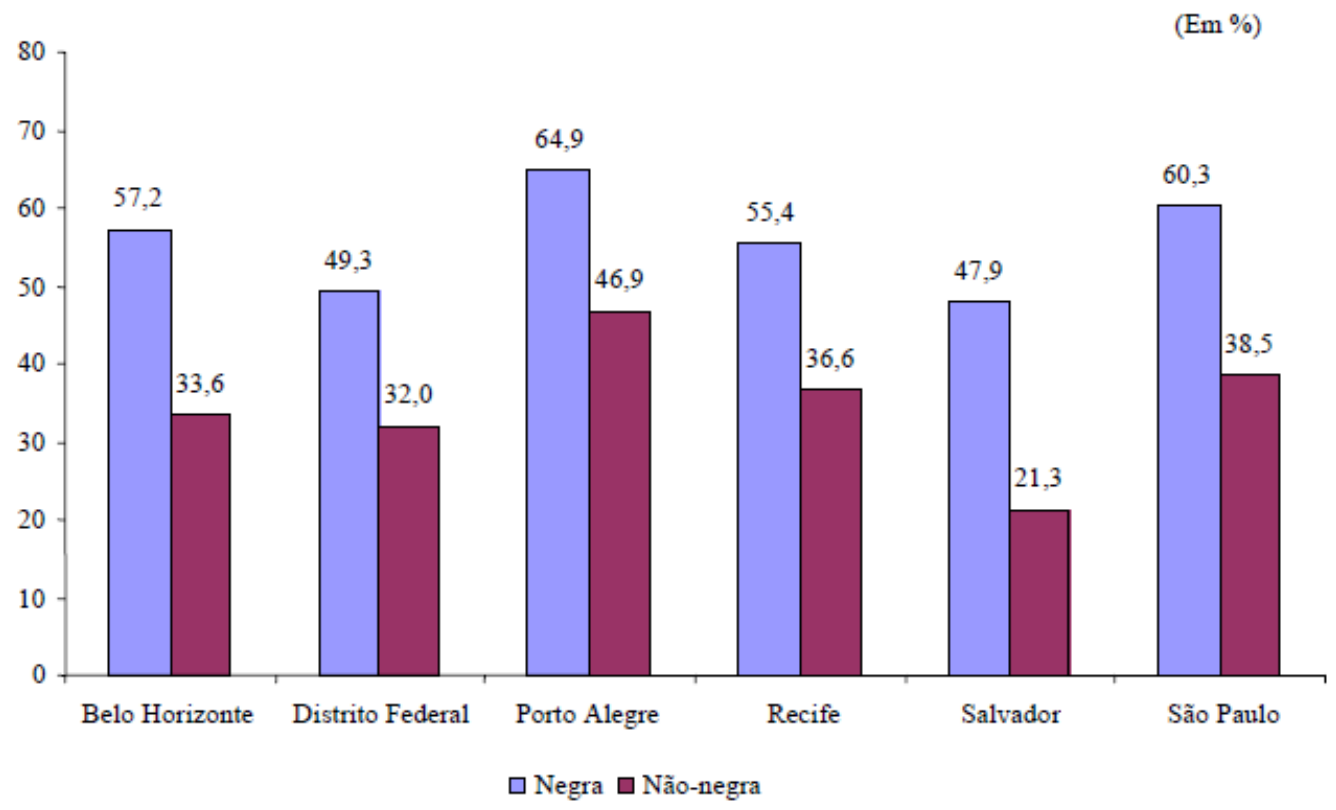

Fonte: DIEESE/SEADE e entidades regionais. PED - Pesquisa de Emprego e Desemprego

Já quanto à participação relativa dos negros nos quadros mais elevados de escolaridade, o porcentual é menor (de 33,5\%, em Porto Alegre, a 52,1\%, em Salvador), enquanto a participação relativa não-negros varia entre um mínimo de 53,1\%, em Porto Alegre, a um máximo de 78,0\%, em Salvador (Gráfico 2). 


\section{GRÁFICO 2}

Percentagem da PEA do ensino médio completo ao superior completo

Regiões Metropolitanas e Distrito Federal - agosto/2006-julho/2007

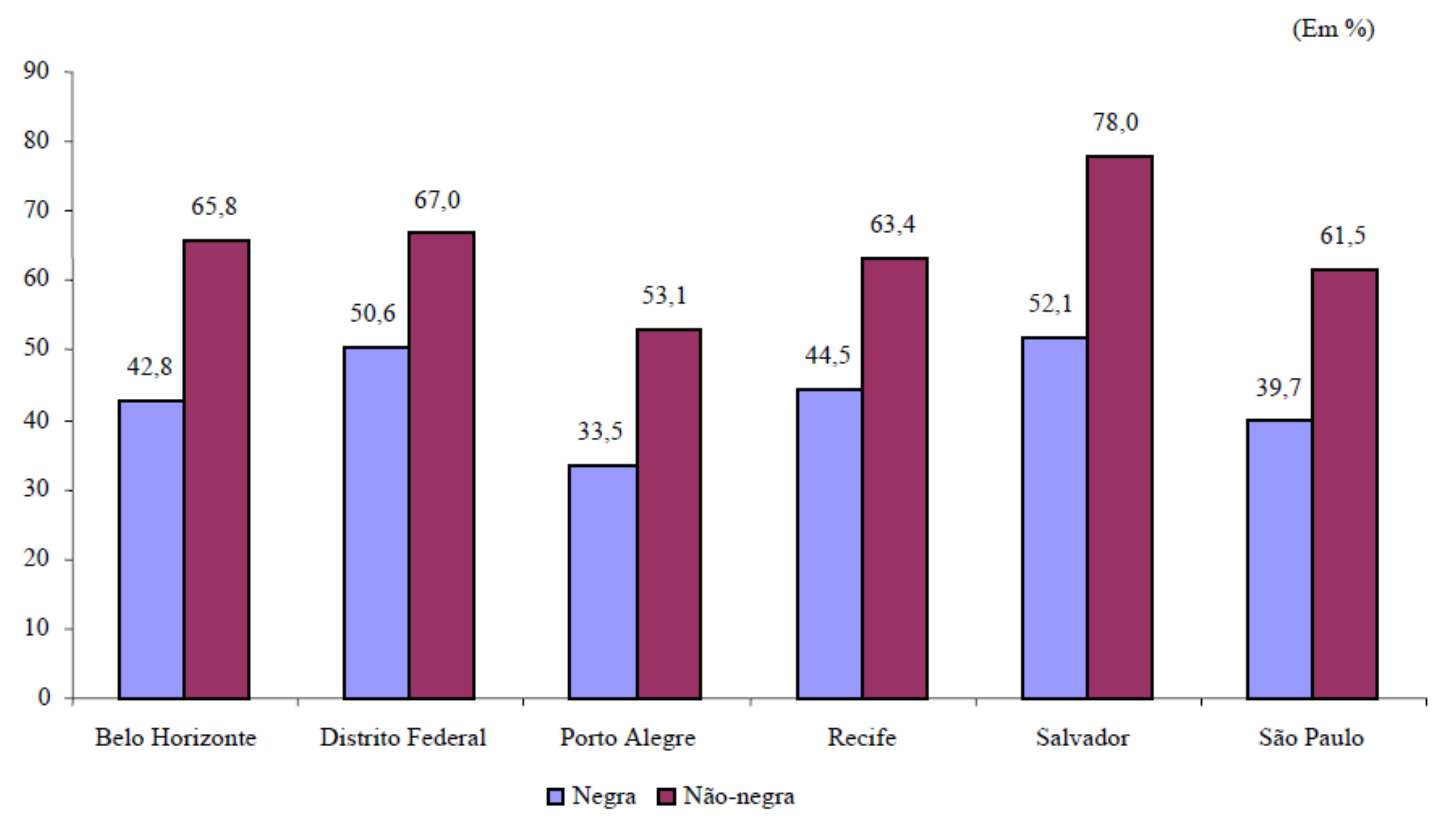

Fonte: DIEESE/SEADE e entidades regionais. PED - Pesquisa de Emprego e Desemprego.

A maior discrepância pode ser verificada no quadro que mostra o acesso ao ensino superior. A parcela de não-negros $(18,9 \%)$ chega a ser quase cinco vezes maior que a de negros (3,9\%), na Região Metropolitana de São Paulo. Mesmo no Distrito Federal, região em que existe a menor desigualdade, a parcela de não-negros $(26,0 \%)$ supera em mais de duas vezes a de negros $(11,9 \%)$, como pode ser verificando no Gráfico 3. 


\section{GRÁFICO 3}

\section{Percentagem da PEA com ensino superior completo}

\section{Regiões Metropolitanas e Distrito Federal - agosto/2006-julho/2007}

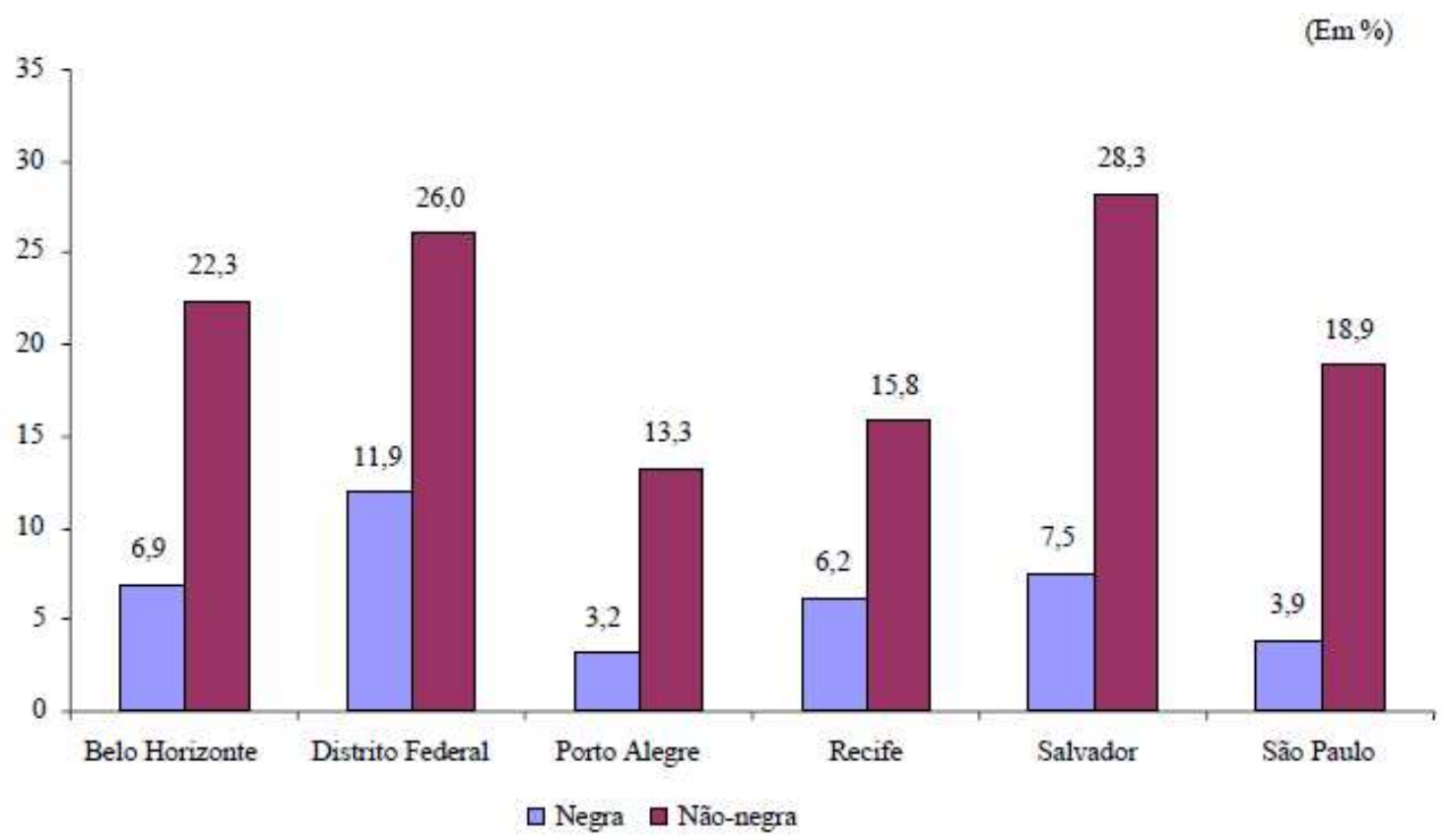

Fonte: DIEESE/SEADE e entidades regionais. PED - Pesquisa de Emprego e Desemprego.

Também o IPEA - Instituto de Pesquisas Econômicas Avançadas realizou estudos sobre o assunto, que divulgou sob o nome de Desigualdades raciais, racismo e políticas públicas: 120 anos após a abolição.

Segundo a instituição, em 1976 cerca de 5\% da população branca possuía um diploma de curso superior aos 30 anos de idade contra um porcentual residual relativo à população negra (0.7\%). Em 2006, quando a pesquisa foi novamente realizada, $5 \%$ dos negros possuíam um diploma de curso superior. Nesse ponto, a desigualdade racial fica evidente: no mesmo ano, verificou-se que $18 \%$ da população branca conseguia obter um diploma superior aos 30 anos. $\mathrm{O}$ hiato que antes correspondia a 4.3 pontos percentuais agora triplicava, alcançando 13 pontos, com se vê no Gráfico 4. 


\section{GRÁFICO 4}

\section{Taxas de Acesso à Formação Superior Branca e Negra no Brasil em 1976 e 2006}
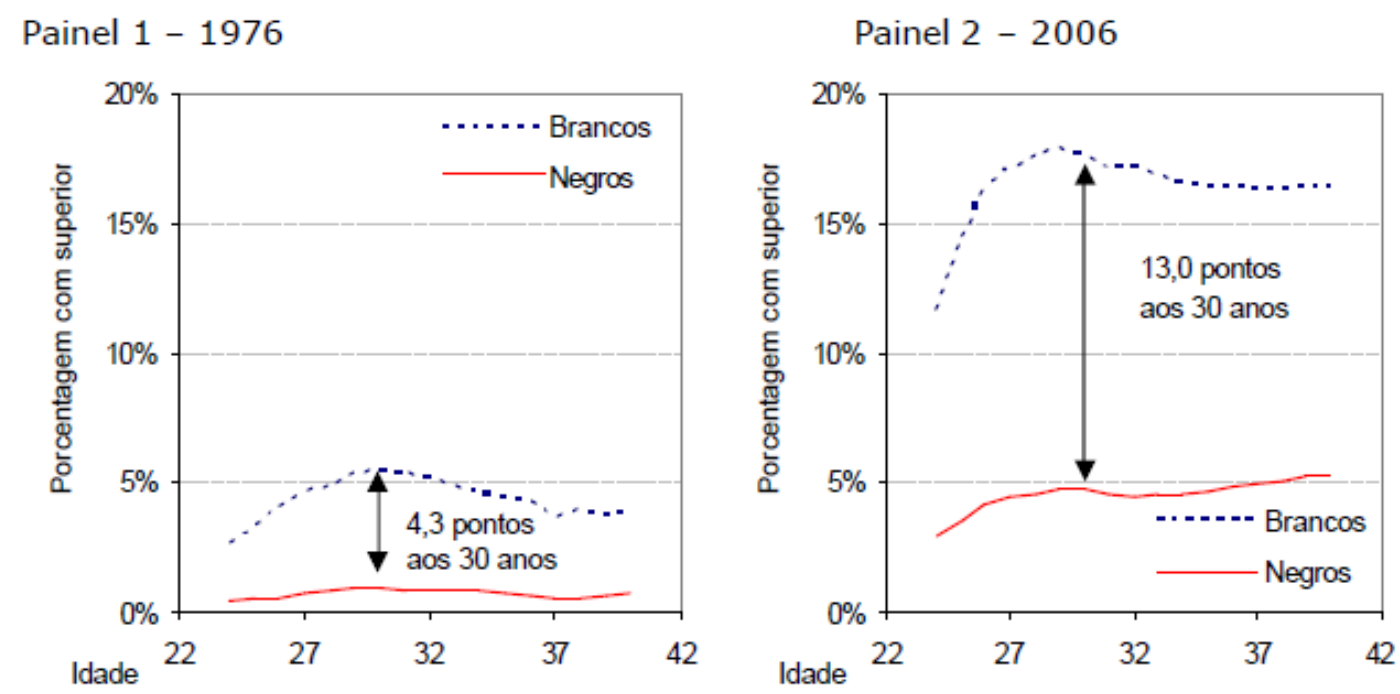

A história da educação superior no Brasil mostra que apenas a implementação de políticas públicas não basta para que haja igualdade racial no Brasil a curto ou médio prazo. É necessário que outras medidas não cerceiem os direitos do negro, pois mais do que incluir, deve-se integrar o negro à sociedade e à realidade do trabalho, da saúde, habitação e renda. Quando a esta última ainda segundo estudos do IPEA têm surgido pequenas mudanças que registraram a partir de 2001 ligeiro declínio nas desigualdades racial e social. Entre 1982 e 1999, a razão de renda entre brancos e negros permaneceu estável em 2.4. Entre 2001, quando a razão alcançou 2.36, e 2006, quando o resultado alcançou 2.11, houve um inegável avanço. Quaisquer que sejam as ações que beneficiem a renda da população em geral, beneficiarão também a população negra, visto que $80 \%$ do décimo mais pobre da população é composto de negros e $80 \%$ do décimo mais rico de cor branca. Qualquer impacto na variação da renda, sabemos ser significativo em termos de melhoria das condições de vida de uma população, principalmente a mais pobre.

Contudo, embora se tenha verificado uma evolução, a velocidade da redução entre a renda de brancos e negros ainda está muito longe de ser a ideal. Considerado o ritmo atual, a renda entre essas duas populações levaria trinta e dois anos para igualar-se, de acordo ainda com os estudos do IPEA. Essa diferença pode ser observada nos Gráficos 5 e 6 a seguir. 
GRÁFICO 5 - Razão de renda entre brancos e negros (histórico)

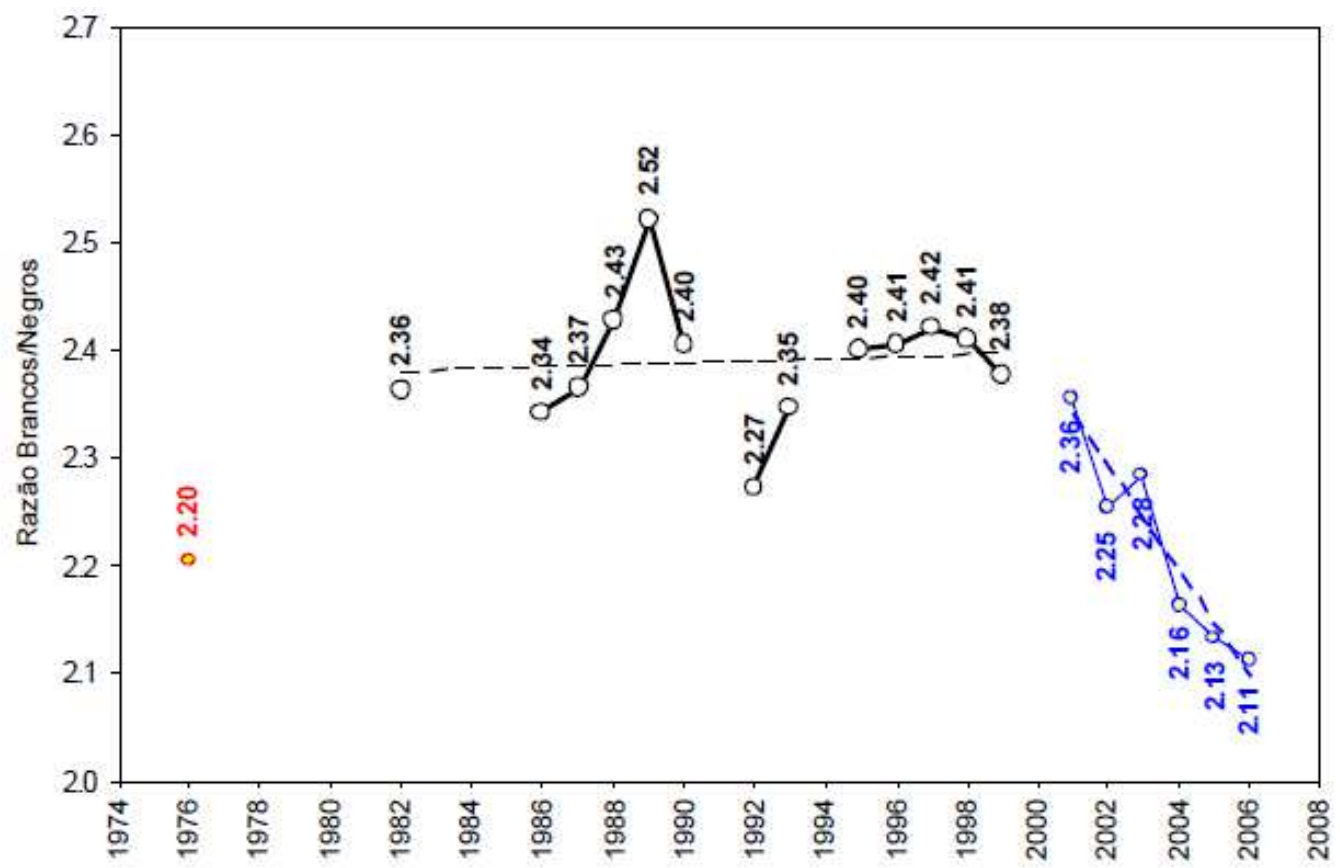

GRÁFICO 6 - Razão de renda entre brancos e negros (projeção)

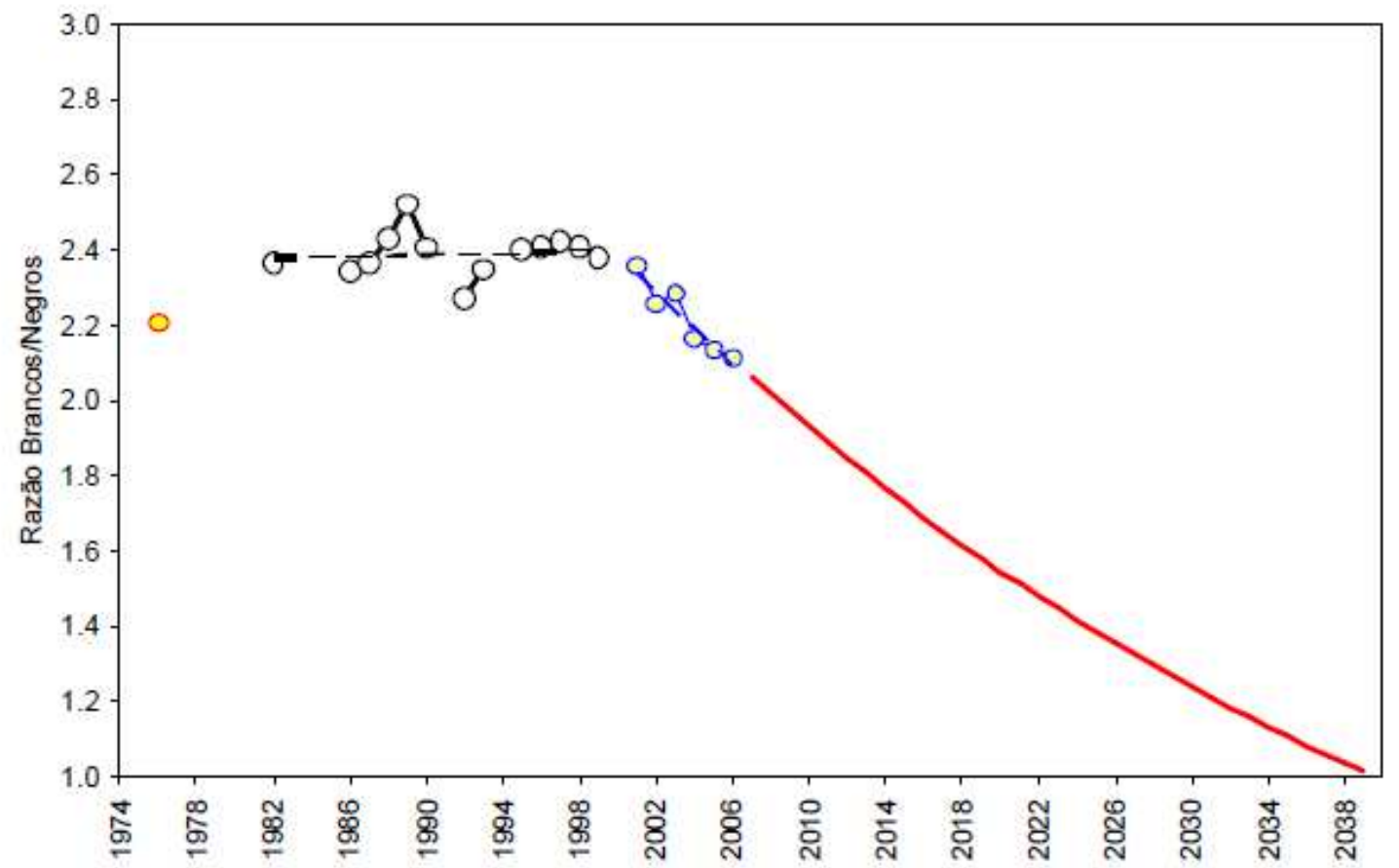

Os efeitos da recente crise global de crédito nos mercados financeiros indicam que a economia dos países desenvolvidos e dos chamados "emergentes" experimentou um período 
de prosperidade que terminou em grave crise, sendo ainda muito incerto quanto tempo perdurarão os efeitos dela. Contudo, uma afirmação parece certa: se com o ritmo acelerado da economia, trinta e dois anos seria o período para que a distância entre renda de brancos e negros diminuisse, é possível que a crise alongue a duração de tempo.

Ampliando os temas das pesquisas mencionadas, um estudo do Instituto Datafolha, realizado na Semana da Consciência Negra de 2008, afirmava em seu Caderno Especial Dossiê Racismo ${ }^{83}$ que o Brasil atualmente se vê menos branco e mais pardo. Uma grande mudança, pois a comparação com os resultados da pesquisa feita em 1995, mostra que pelo menos metade da população se assumia como branca. Treze anos depois, o percentual de brancos alcançou 37\%, próximo aos que se declaram pardos (36\%). Os classificados como pretos representaram $14 \%$ entre pessoas com 16 anos ou mais.

Este movimento está de acordo com o que mostram as pesquisas do IBGE: em 2007, pela primeira vez na História, a soma de pretos e pardos superou a de brancos no total da população.

De acordo com o Datafolha, duas razões principais explicam o crescimento dos autodeclarados pretos e pardos. A primeira é demográfica. O Relatório Anual das Desigualdades Raciais no Brasil, organizado pelos pesquisadores Marcelo Paixão e Luiz Carvano, mostra que, em 1995, o número médio de filhos de mulheres pretas e pardas era 3,0. Entre brancas, a taxa era de 2,2. Dez anos depois, a diferença caiu, mas as mulheres pretas e pardas seguem tendo, em média, mais filhos $(2,3$ ante 1,9$)$.

Entretanto, a definição de cor ou raça pelo IBGE é autodeclaratória, sendo o entrevistado quem escolhe entre cinco opções fornecidas. Essa é a outra razão apontada pelos especialistas para tal aumento, pois pessoas que antes se identificavam como brancas deixaram de fazê-lo.

No relatório de Paixão e Carvano, comparou-se a geração que, em 1995, tinha de 10 a 29 anos, e, em 2005, de 20 a 39 anos. Mesmo nesse grupo - em tese, a mesma população dez anos depois - foi verificado aumento de pretos e pardos.

Esses dados - aumento de população, declaração de cor diferente da branca - entre outros, apontam para uma maior conscientização do negro em relação às suas possibilidades e

83 Folha de São Paulo, Caderno Especial Racismo, 23 de novembro de 2008. Disponível em <http://www1.folha.uol.com.br/fsp/especial/inde23112008.htm> 
direitos. Conscientização que desde a abolição alguns abnegados ou ideologizados lutaram para difundir através de associações e jornais. É essa história de luta e resistência em São Paulo que se pretende descrever nas páginas seguintes. 


\section{Capítulo 2 - Primeiras reações coletivas à exclusão: irmandades e outras associações}

Em realidade, sabemos que as primeiras associações criadas em São Paulo visavam apoiar o negro na dura travessia entre o fim da abolição e a nova realidade trazida pelo trabalho livre, onde a pobreza e a falta de oportunidades estavam sempre presentes. Essas associações nasciam de necessidades sociais próprias da comunidade negra na Capital.

Tais necessidades não são vistas somente a partir da presença de cativos e libertos no ambiente urbano ou a partir da união de grupos provenientes de fazendas ou ajuntamentos. Desde o século XVI, durante o transporte forçado de escravos africanos, verificou-se a formação de espaços privilegiados de sociabilidade a bordo dos navios negreiros, em que homens e mulheres podiam expressar seus medos. Grupos de cativos construíam redes de solidariedade e companheirismo. Malungo era a palavra banto que expressava esse sentimento de cumplicidade ${ }^{84}$.

O termo, conhecido por viajantes como o inglês Henry Koster e o bávaro Rugendas, dizia respeito a "uma espécie de fraternidade entre os indivíduos trazidos na mesma embarcação". Eram relações surgidas a bordo dos navios negreiros, onde os africanos se manifestavam de forma melancólica e barulhenta, mesmo pertencendo a diferentes etnias.

Os malungos, no entanto, não eram apenas companheiros de viagem, como bem aponta o historiador Robert W. Slenes. Para o autor de $N a$ Senzala, uma flor ${ }^{85}$ e Família Escrava e Trabalho ${ }^{86}$, por terem uma mesma origem linguistica, a identidade entre os diversos grupos bantos trazidos para o Brasil começava até mesmo na própria África, no percurso que ia desde a captura e a transformação do negro em prisioneiro, passando pelos caminhos terrestres, até a chegada ao porto brasileiro e ao domicílio do proprietário. Um longo trajeto já teria sido percorrido antes da conversão do negro africano em escravo, criando solidariedades e identidades próprias. Como cativos, terminavam por criar outras.

\footnotetext{
${ }^{84}$ Também é possível encontrar a grafia bantu. A palavra banto pode ser utilizada tanto como adjetivo como sustantivo masculino ou feminino. Para os demais significados da palavra malungo e de outros verbetes do tronco linguistico banto, ver LOPES, Nei. Novo Dicionário Banto do Brasil. Rio de Janeiro: Pallas, 2003, p. 135. ${ }^{85}$ SLENES, Robert. Na Senzala, Uma Flor: Esperanças e Recordações na Formação da Família Escrava (Brasil Sudeste, Século XIX) . Rio de Janeiro - RJ: Nova Fronteira, 1999.

${ }^{86}$ SLENES, Robert. Família Escrava e Trabalho. Tempo - Revista do Departamento de História da UFF, Rio de Janeiro, v. 6, 1998, p. 37-42.
} 
O historiador sugere, por exemplo, que o termo malungo, tendo o duplo significado de companheiro (ou companheiro de sofrimento) e de barco/canoa em várias línguas dos habitantes da África central, aqui no Brasil adquiriu um sentido ainda mais amplo significava os que foram companheiros na travessia da kalunga (linha divisória, representada pelas águas do rio ou do mar, que separava o mundo dos vivos, do mundo dos mortos $)^{87}$. Desta forma, mesmo antes de transformados em escravos, na América, os bantos de variadas origens teriam criado pontos comuns que iam além das suas culturas de origem, ressignificando conceitos e criando novas formas de identidade.

$\mathrm{Na}$ verdade, o clima de fraternidade e solidariedade entre cativos era algo perigoso para os capitães negreiros. Mesmo vigiados e reprimidos, os escravos se rebelavam a bordo dos navios. Isso não era propriamente uma regra, mas algo comum, que exigia cuidados especiais, como a presença de marinheiros intérpretes, muitos deles também escravos ${ }^{88}$.

A rebelião e as formas de resistência escravas são bastante conhecidas na historiografia, e remontam à época em que o primeiro negro escravo colocou os pés no Brasil: mulheres que matavam seus filhos para não vê-los escravos, cativos que recorriam ao banzo a doença representada pela melancolina profunda durante a travessia - , as revoltas de escravos e os assassinatos contra seus senhores e feitores, a formação das casas de candomblé e dos quilombos.

Além da violência que várias formas de resistência encerravam, houve outras expressas de forma diferente. Dada sua condição de agente espoliado dentro da estrutura econômica do país desde o período colonial, tornou-se necessária para os negros cada vez mais a volta às origens, buscando fios e traços de solidariedade e fraternidade para que fossem lembrados, cultivados e difundidos junto à população negra. Surgem e se desenvolvem, assim, antes e depois da Abolição, as associações, as irmandades e as sociedades de apoio à comunidade negra nas grandes cidades.

Após a abolição, os negros tiveram que desenvolver um esforço próprio de autoeducação e de auto-esclarecimento, em escala coletiva. Mais tarde, os movimentos sociais, que passaram a ser identificados como os precursores do protesto negro, moveram diversas

\footnotetext{
${ }^{87}$ SLENES, Robert. "'Malungu, Ngoma vem'!: África coberta e descoberta no Brasil", Redescobrir os Descobrimentos: as Descobertas do Brasil, São Paulo, Revista USP, Ed. 12 (dez, jan, fev), 1990-1992.

${ }^{88}$ SILVA, Luis Geraldo. A faina, a festa e o rito: uma etnografia histórica sobre as gentes do mar, sécs. XVII ao XIX. Campinas: Papirus, 2001, p. 66.
} 
campanhas: a reabilitação da mãe solteira, uma vez que aumentava a possibilidade de mais menores desamparados e dificultava o casamento ou a constituição da família, o incentivo à responsabilidade do pai na educação dos filhos e na manutenção do lar, o abandono dos porões e cortiços e planejamento para a aquisição da casa própria, a valorização das profissões acessíveis considerando as habilitações e o combate ao analfabetismo, o alcoolismo e a prostituição no meio negro.

Muitos estudos já foram feitos sobre as irmandades, confrarias e associações negras no Brasil. Há dissertações, teses de doutorado e livros que falam das associações em Porto Alegre, Pernambuco, Bahia, Minas Gerais, Rio de Janeiro e São Paulo e sua atuação entre os séculos XVI e XIX.

Famosas são a Irmandade da Igreja de Nossa Senhora da Lampadosa, o segundo templo doado a negros na cidade do Rio de Janeiro (o primeiro foi o da Irmandade Nossa Senhora do Rosário e São Benedito dos Homens Pretos) e a Irmandade de Nossa Senhora da Boa Hora de Olinda, constituída nos idos de 1787.

No início, essas irmandades surgiram da necessidade dos negros de praticar sua religiosidade sob o manto da Igreja Católica. Chegando ao Brasil, tiveram que negar as crenças em seus deuses (Orixás), entre eles Exú, Xangô, Iansã, Iemanjá e Obatalá. Como forma de manterem a religiosidade, passaram a cultuar santos da Igreja Católica: tinham como patronos Santa Efigênia, Santo Antonio de Categerona, São Gonçalo e Santo Onofre, mas São Benedito e Nossa Senhora do Rosário eram os mais cultuados, principalmente por aqueles de procedência bantu. Podemos dizer que a fraternidade e a solidariedade criadas entre os malungos foram uma das manifestações que tornaram possível a criação de tais associações e irmandades.

Entre todas as irmandades e confrarias, as mais recorrentes são as que se devotam a Nossa Senhora do Rosário. Seu culto foi divulgado principalmente pelos dominicanos:

O papa dominicano Pio V (1566-1572) criou a festa do rosário em "memória de nossa querida Senhora da vitória". À devoção do rosário foram atribuídas ainda vitórias como a libertação de Viena das tropas turcas em 1683 por Carlos, imperador dos romanos, e a vitória do príncipe Eugênio sobre os turcos em 1716 perto de Neusatz no Danúbio. Nesta última ocasião o papa Clemente XI estendeu a festa do Rosário para toda a Igreja, colocando-a no primeiro domingo de outubro. Esta associação entre libertação da escravidão, alforria, resgate (algumas traziam esta função no próprio título) e Nossa Senhora do Rosário, me parece, é a que melhor nos ajuda a entender a sua grande popularidade entre os escravos. Sua devoção 
supera todas as demais. Seu culto foi divulgado pelos dominicanos, que também ajudaram a popularizar o terço. ${ }^{89}$

A oração à Nossa Senhora do Rosário também nos ajuda a entender a referida popularização do terço, instituída por São Domingos como agradecimento e devoção à santa:

Oração a Nossa Senhora do Rosário

Nossa Senhora do Rosário,
dai a todos os cristãos a graça
de compreender a grandiosidade
da devoção do santo rosário,
na qual, à recitação da Ave Maria
se junta a profunda meditação
dos santos mistérios da vida,
morte e ressurreição de Jesus,
vosso Filho e nosso Redentor.
São Domingos, apóstolo do rosário,
acompanhai-nos com a vossa bênção,
na recitação do terço, para que,
por meio desta devoção a Maria,
cheguemos mais depressa a Jesus,
e como na batalha de Lepanto,
Nossa Senhora do Rosário nos leve a vitória
em todas as lutas da vida;
por seu Filho, Jesus Cristo,
na unidade do Pai e do Espírito Santo.
Amém 90

O culto a essa santa sempre foi desenvolvido pelos negros em diversas regiões do Brasil. Em São Paulo, organizaram a Irmandade de Nossa Senhora dos Homens Pretos, também conhecida como "Pretos do Rosário de São Paulo". Como outras, ela nasceu da impossibilidade dos negros exercerem livre e impunemente suas crenças africanas e da necessidade em se organizarem socialmente para evitarem o estado de anomia. Fundada em 2 de janeiro de 1711, durante o governo de Dom Antônio de Albuquerque Coelho Carvalho, primeiro Capitão General da Capitania de São Paulo, seu primeiro estatuto data de 1808 e o registro foi oficializado em 4 de janeiro de 1809, com 29 artigos. No mesmo ano de sua fundação, foi criada a Irmandade do Rosário dos Homens Brancos para diferenciá-la da que estamos mencionando ${ }^{91}$.

Com o passar do tempo, os associados construíram uma modesta e precária capela em terra devoluta, para a qual já haviam solicitado sino e ornamento ao Rei, mas não possuíam

\footnotetext{
${ }^{89}$ QUINTÃO, Antonia Aparecida. Lá vem o meu parente: as irmandades de pretos e pardos no Rio de Janeiro e em Pernambuco (Século XVIII). São Paulo: Annablume: Fapesp, 2002, p.79.

${ }^{90}$ Disponível em <http://www.paroquias.org/oracoes/?o=71> Acesso em 9 de agosto de 2009.

${ }^{91}$ RODRIGUES, Argemiro. Irmandade Nossa Senhora do Rosário dos Homens Pretos. São Paulo: Fundação Carlos Chagas. Caderno de Pesquisa nº 63, pp.137-138.
} 
condições econômicas para a manter a Associação. O ermitão Domingos de Mello Tavares embrenhou-se pelos sertões por quase sete anos recolhendo esmolas, e após arrecadar dez mil cruzados, pediu provisão de Administração Perpétua da Igreja como fundador e tesoureiro da Irmandade em 1725, sendo antendido em 5 de dezembro do mesmo ano pelo Bispo da Capital.

Existem controvérsias quanto à data exata da construção da velha igreja dos negros, mas acredita-se que tenha ocorrido entre 1725 e 1750. Nos primeiros tempos, havia a festa da Irmandade de Nossa Senhora do Rosário dos Homens Pretos, que começava com uma missa solene e circunspecta. Depois, até homens brancos acudiam aos arredores da Igreja para assistir às tradicionais congadas (ou festas de Congos), reminiscências perdidas nas tradições dos escravos.

A velha matriz do Rosário, onde hoje está situada a Praça Antonio Prado, foi obra de malungos, irmãos que vinham em auxílio de outros através do trabalho em cooperativa, primeiramente sob a orientação do próprio Domingos Mello Tavares, passando depois às mãos do sargento-mor Sebastião Fernandes Dokpower. ${ }^{92}$

Essa irmandade assumiu especial importância no contexto religioso de São Paulo, pois além das práticas ortodoxamente católicas, seus integrantes praticavam o culto aos mortos e possuiam um cemitério contíguo à igreja, onde os irmãos eram sepultados. Segundo Raul Joviano do Amaral, um dos membros mais antigos da Irmandade e uma das mais conhecidas lideranças da imprensa negra paulista nos anos de 1920 e 30, "esse costume - o dos enterros dos mortos nas igrejas -, que era uma velha praxe geral, foi revogado pela provisão do Príncipe Regente, em 1810, quando ratificou a forma do Compromisso da Irmandade". Os sepultamentos eram feitos quase sempre à noite, com acompanhamento dos $\operatorname{Irmãos}^{93}$.

A comunidade era formada por "quartos", assim chamadas as unidades habitacionais ocupadas por famílias de negros africanos que, depois de conseguirem a liberdade, instalavam-se nas casas, estabelecendo nelas, em geral, elementos para ganhar a vida:

\footnotetext{
${ }^{92}$ Sobre o ermitão Domingos de Mello Tavares e a fundação Irmandade de Nossa Senhora do Rosário dos Homens Pretos de São Paulo, ver MOURA, Clóvis. Dicionário da Escravidão Negra no Brasil...op.cit.; DICK, Maria Vicentina de Paula do Amaral. A dinâmica dos nomes na cidade de São Paulo (1554-1897). São Paulo: Annablume, 1996, p. 174 e DIAFÉRIA, Lourenço. A caminhada da esperança. São Paulo: Edições Loyola, 1996, p.71.

${ }^{93}$ AMARAL, Raul Joviano do. Os Pretos do Rosário. Subsídios Históricos. 1ª edição. São Paulo. Alarico, 1954. Falaremos mais a respeito de Raul Joviano do Amaral e de sua atuação nos jornais negros em capítulos mais adiante.
} 
Nas pequenas casas [cômodos] de porta e janela, primitivamente de propriedade da Venerável Irmandade N.S. do Rosário dos Homens Pretos até mais ou menos 1890, residiam forros e libertos, cuja ocupação era a prestação de serviços: carregamento de água, limpeza das casas grandes, roçadas e limpezas de sítios e chácaras, e a quitanda: comércio de doces, bolos, geléias, pinhão, milho verde cozido, mandiocas, legumes, hortaliças, frangos e galinhas, venda de quinquilharias, etc. ${ }^{94}$

Nas palavras de Raul Joviano do Amaral, "a existência da Irmandade dos Rosários dos Homens Pretos de São Paulo se desenvolveu sempre num clima de ameaças e intranquilidade".

As ameaças vinham do ambiente externo e a intranquilidade era percebida nos desentendimentos internos. Existem notícias de frequentes extravios de documentos nos primeiros anos, alguns em poder de particulares, outros em mãos de membros da Irmandade, que seriam de grande valia para explicar o contexto paulista da época.

Ao mesmo tempo, forças externas pressionavam a instituição: as casas pertencentes à Irmandade, nas quais os africanos moravam, necessitavam ser desapropriadas para que fosse viabilizado o projeto de expansão urbana e aformoseamento de São Paulo. A referida desapropriação já constava do orçamento enviado para aprovação da Câmara de São Paulo em 1870. Nesse mesmo ano foi aprovado também um novo Compromisso para a Irmandade, por exigência do Juiz de Capelas, para quem o estatuto precisava ser atualizado e necessitava de novas disposições. O Compromisso era o estatuto que regia as irmandades, devendo ser endossado pelas autoridades eclesiásticas e pelos monarcas. Nele estavam contidos os objetivos da irmandade, o seu funcionamento, as obrigações de seus membros, assim como os direitos adquiridos ao se tornarem membros dessas associações.

De acordo com Antonia Aparecida Quintão, que pesquisou o tema, a aprovação desse documento, em substituição ao de 1810, evidenciava a centralização do poder nas mãos do Juiz Provedor, que passava assim a ter controle inclusive sobre todos os bens pertencentes à Irmandade. A pesquisadora observa que a obrigatoriedade do exercício dos cargos de juiz, juíza, rei e rainha por pessoas negras, antes presente no antigo estatuto, desaparece no novo compromisso.

Ao final, as casas e os terrenos que pertenciam à Irmandade foram desapropriados entre 1871 e 1872 :

\footnotetext{
${ }^{94}$ AMARAL, Raul Joviano do. op. cit. apud ROLNIK, Raquel. A cidade e a lei: política urbana e territórios na cidade de São Paulo. São Paulo: Studio Nobel, 1997, p. 63
} 
"A Câmara Municipal da capital, achando de muita conveniência a abertura de um
largo, entre a rua São Bento e a do Rosário, resolveu, em sua sessão de 29 de
fevereiro de 1872 , presidida pelo tenente-coronel Bento José Alves Pereira,
desapropriar para esse fim, os pequenos prédios e o terreno que servia de cemitério,
contíguo à antiga Igreja do Rosário e pertencentes à irmandade da mesma santa,
sendo que aqueles pequenos prédios, que confinavam com o referido cemitério,
eram habitados por casais de pretos africanos, os quais , depois que conseguiam
libertar-se do cativeiro, se estabeleciam nos mesmos prédios em que residiam, com
suas quitandas".

Tais medidas foram responsáveis por uma crise na Irmandade, pois, com certeza, e após a destituição do direito sobre os casebres e o cemitério, viria a igreja a ser arrancada dos irmãos, o que realmente ocorreu. Através da lei 698, de 24 de dezembro de 1903, com a desapropriação veio uma indenização de 250 contos de réis e uma pequena área no Largo do Paisandú para a edificação de outra.

Em 1905, o antigo Largo do Rosário passou a chamar-se Praça Antonio Prado. Passavam por ali diversas linhas de bondes, confeitarias e restaurantes lá se instalavam. Não por acaso, o terreno onde antes era o cemitério passou às mãos de Martinico Prado, irmão do então prefeito. Erigiu-se ali o Palacete Martinico Prado, um prédio que já abrigou o Citibank e agora a Bolsa Mercantil \& de Futuro.

Ainda em 1905 foi lançada a pedra fundamental da nova igreja, sendo responsável pela sua construção a firma Rossi \& Brenni, vencedora da concorrência. Enquanto isso, a Irmandade instalou-se provisoriamente, com todos os seus pertences, na Igreja de São Pedro da Pedra, no Largo da Sé. Em 7 de janeiro de 1905 procedeu-se ao telhamento do novo edifício, e em 1906 foi então inaugurado o templo da Irmandade Nossa Senhora dos Homens Pretos, que permanece até hoje, no atual Largo do Paisandú. Fica defronte (ou, antes, inclinada) à Avenida São João. Tem uma porta frontal, por onde entram os fiéis, e outra lateral, cuja escada dá acesso à sacristia. A porta dos fundos leva ao subsolo, de acesso restrito aos membros da Irmandade. ${ }^{96}$

A história de resistência da Irmandade emociona muito se levarmos em conta que as dificuldades não ocorreram somente com a desapropriação e a transferência no início do século XX:

(...) Em 1940, o prefeito de São Paulo, Francisco Prestes Maia, propôs a demolição da [sua] igreja baseado em três objetivos principais: o primeiro de ordem estética, ou

\footnotetext{
${ }^{95}$ SANT'ANNA, Nuto. Metrópole. Vol. XXXIX IN: QUINTÃO, Antonia Aparecida. Irmandades Negras: outro espaço de resistência (São Paulo: 1870-1890). Fapesp/Annablume. São Paulo: 2002. p. 13-14.

${ }^{96}$ MOURA, Clóvis. Dicionário da Escravidão...op.cit., p. 218 e BARBUY, Heloísa. A cidade exposição. São Paulo: EDUSP, 2006, p.50.
} 
seja, harmonizar a praça com as novas construções do local. O segundo objetivo: melhorar a circulação de trânsito com o alargamento da avenida e a terceira justificativa era transformar as praças num local digno de receber um monumento ao Duque de Caxias ${ }^{97}$.

A Irmandade aceitou, inclusive, uma proposta de mudança para a Barra Funda, mas devido ao falecimento de D. José Gaspar de Affonseca e Silva, cardeal arcebispo de São Paulo e presidente da comissão pró-monumento, a negociação estendeu-se sem solução definitiva até 1945, quando o substituto de Maia achou mais conveniente erigir a herma de Caxias na Praça Princesa Isabel ${ }^{98}$.

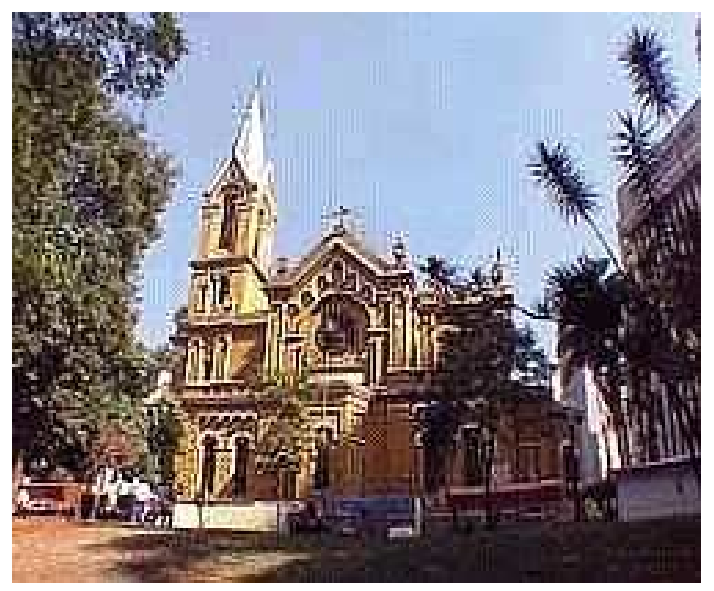

\section{Figura 1}

Igreja de Nossa Senhora do Rosário dos Homens Pretos

A capela de Nossa Senhora dos Homens Pretos está hoje sob a jurisdição da paróquia de Santa Ifigênia. No subsolo fica a mesa administrativa, onde os irmãos se encontram para a celebração da missa de domingo, para confraternização e distribuição mensal de cerca de 150 cestas básicas. $\mathrm{O}$ ambiente é permeado por recordações, mantidas num acervo de pinturas, ilustrações, fotografias, imagens e documentos que trazem à lembrança os primeiros irmãos.

A eleição da diretoria é anual para os cargos de juiz provedor, secretário, tesoureiro e procurador, que exercem atividades administrativas e pastorais na comunidade, incentivando a formação da juventude, de equipes de música e de liturgia. Nessa ocasião, também são eleitos os festeiros, o rei e a rainha, que juntos com o juiz e a juíza organizam, durante o ano, com o apoio das irmãs e dos irmãos, as festas de Nossa Senhora do Rosário e São Benedito. Estima-se que a Irmandade possua hoje mais de 200 membros.

\footnotetext{
${ }^{97}$ QUINTÃO, Antonia Aparecida. Irmandades negras... p. 106.

${ }^{98}$ Idem, ibidem, p. 107
} 
Os Irmãos recebem pesquisadores, religiosos, pessoas de outros estados e até do exterior, interessados em conhecer e estudar as razões de tanta longevidade. O interior da igreja apresenta uma variedade de detalhes nas pinturas das paredes, nas vestimentas e adornos dos santos e nas luzes do altar-mor que se refletem entre lustres, candelabros e flores.

Outras irmandades podem ser consideradas espaços de luta e resistência do negro em São Paulo, como a Irmandade de Santa Efigênia e Santo Elesbão (1794), a Irmandade de Nossa Senhora dos Remédios (criada por Antonio Bento em 1877) e a Irmandade de São Benedicto da Cidade de São Paulo (criada em 17 de fevereiro de 1896).

Antonia Quintão buscou informações sobre a Irmandade de Santa Efigênia e Santo Elesbão em São Paulo, cujo símbolo atual é a Igreja de Santa Ifigência, situada em rua e bairro de mesmo nome.

A origem da Igreja de Santa Efigênia remonta à construção da Capela de Nossa Senhora da Conceição, em 1720. Essa primeira capela foi reformada em 1794 e, conforme edito do Príncipe Regente Dom João VI, em 1809, surgiu a Paróquia de Nossa Senhora da Conceição e Santa Efigênia, que deu nome ao largo e ao bairro ao seu redor. O nome de Santa Efigênia foi adicionado em razão da igreja abrigar negros alforriados, que se congregavam no templo para missas e o culto da santa ${ }^{99}$.

Santa Efigênia era um dos “dois Atlantes de Etiópia”, juntamente com Santo Elesbão, nas palavras do carmelita Frei José Pereira de Santana ${ }^{100}$, tendo ambos vivido em terras africanas e considerados exemplos de virtudes cristãs.

A santa assim como Santo Elesbão, pertencia à nobreza: princesa da Núbia, filha do rei Egyppo, teria sido convertida ao cristianismo, sendo batizada pelo apóstolo Mateus. Indiferente aos prazeres mundanos e aos requintes da Corte, tornou-se religiosa fundando um convento. Após a conversão e a morte do pai, seu tio - Hitarco - teria usurpado o trono do herdeiro legítimo - Efrônio -, irmão de Efigênia, tentando desposá-la para consolidar seu

\footnotetext{
${ }^{99}$ Disponível no sítio oficial da Igreja de Santa Ifigênia, em <http://santaifigenia.sites.uol.com.br/santa.html,> acesso em 9 de agosto de 2009, e no sítio do Departamento do Patrimônio Histórico de São Paulo, disponível em <http://www.prefeitura.sp.gov.br/cidade/secretarias/cultura/patrimonio_historico/ladeira_memoria/index.php?p= 354>, Acesso em 9 de agosto de 2009.

${ }^{100}$ SANTANA, Frei José Pereira de. Os Dois Atlantes de Etiópia. Santo Elesbão, Imperador XLVII da Abissínia, Advogado dos perigos do mar \& Santa Efigênia, Princesa da Núbia, Advogada dos incêndios dos edifícios. Ambos Carmelitas. Lisboa: Oficina de Antonio Pedrozo Galram, 1735-1738 IN:OLIVEIRA, Anderson José Machado de. Devoção e identidades: significados do culto de Santo Elesbão e Santa Efigênia no Rio de Janeiro e nas Minas Gerais no Setecentos. TOPOI, v. 7, n. 12, jan-jun. 2006, pp.60-115. Disponível em <http://www.revistatopoi.org/numeros_anteriores/topoi12/topoi12a3.pdf> Acesso em 31 de maio de 2009.
} 
poder na Núbia. Efigênia teria se recusado a atendê-lo, despertando-lhe profunda ira. Hitarco mandou atear fogo à habitação religiosa onde viviam Efigênia e as religiosas que ela liderava, mas o convento foi milagrosamente salvo por intercessão da santa.

Efigênia foi também figura importante na recuperação do trono por seu irmão, restabelecendo o bom governo na Núbia com a morte do usurpador. Tanto ela quanto Elesbão (Imperador da Etiópia) teriam seguido a vida religiosa, de acordo com a regra carmelita.

Desde 1740 no Rio de Janeiro e a partir de 1794 em São Paulo e Minas Gerais (Mariana), a Irmandade de Santa Efigênia e Santo Elesbão parecia congregar um movimento de associação e solidariedade entre negros africanos em torno de folias, entendidas primeiramente como a dança ao som do pandeiro. Posteriormente, ao ser adicionada ao Compromisso da Irmandade, previa a criação de um "Estado", sendo eleitos Imperador, Imperatriz, Príncipe e Princesa. O Imperador era designado no Compromisso como o “Glorioso Santo Imperador". Previa-se também a eleição, entre os membros da Irmandade, de sete reis para o dito "Estado". A folia era obrigada a participar "nas ocasiões festivas para maior grandeza e aplauso dos ditos santos". 101

Da mesma forma, Antonia Quintão reforça as informações acima, argumentando que existia forte elo de ligação entre as irmandades em São Paulo, a partir da de Nossa Senhora do Rosário dos Homens Pretos, passando pela Irmandade de Santa Efigênia e Santo Elesbão, pela de São Benedito e até pela Irmandade de Nossa Senhora dos Remédios, local de encontro dos caifazes de Antonio Bento ${ }^{102}$.

Conforme mencionado anteriormente, a aprovação de um novo Compromisso para a Irmandade de Nossa Senhora do Rosário em 1870 não pressupunha somente uma alteração nas regras da comunidade e de seus membros, mas significava a concentração do poder nas mãos do Juiz Provedor em relação às irmandades negras, que poderia arbitrar sobre a necessidade ou não até de sua existência. A Irmandade de Santa Efigênia e Santo Elesbão não

\footnotetext{
${ }^{101}$ AISESEF - Compromisso da Venerável Irmandade de Santo Elesbão e Santa Efigênia do Rio de Janeiro, 1740, fols. 29-31 IN: OLIVEIRA, Anderson José Machado de. Op.Cit. p.14.

102 Antonio Bento de Souza e Castro (1843-1898) foi promotor público, juiz e abolicionista. Organizou, em 1877, a Confraria de Nossa Senhoras dos Remédios, e em 1880 conheceu Luiz Gama, negro e líder do movimento emancipador na então Província de São Paulo. Com a morte de Gama, em 24 de agosto de 1882, Antonio Bento assume a liderança do movimento abolicionista paulista, através de um grupo denominado "os caifazes". Este movimento enviava emissários ao interior da Província, que entravam em contato com os escravos das fazendas e lhes incentivavam a fuga, garantindo recursos para as viagens e refúgios. Eram enviados ao quilombo do Jabaquara, em Santos, e dali à Província do Ceará, onde já havia sido decretada a abolição.
} 
fugiu a essa interferência. Em 1890, após um longo período de conflito com o vigário José de Camargo Barros, os Irmãos não só tiveram sua irmandade dissolvida, como foram despejados da igreja por eles mesmos construída.

Como uma sociedade civil com personalidade jurídica protegida pelas regras do Direito Civil, a Irmandade recorreu da decisão. Através de seu advogado, Dr. José Fernandes Coelho, reivindicava não somente as salas da irmandade mas também o prédio da igreja. $\mathrm{O}$ advogado do vigário, Dr. João Mendes de Almeida Jr., alegou que o foro regular não era competente para julgar a matéria.

Recorreu-se ao Tribunal da Relação, que por três votos contra um, confirmou a incompetência do juízo secular na matéria, encerrando o pleito em 10 de maio de $1890^{103}$.

Quanto à igreja colonial de Santa Efigênia, em São Paulo, foi demolida em 1904, tendo sido reinaugurada em 1910, ainda inacabada, poisa as obras terminaram em 1913. O estilo arquitetônico, em nada parecido com o antigo edifício colonial, tem caráter neoromânico com detalhes neogóticos, inspirado em igrejas medievais do norte da Europa. Entre 1913 e 1954, tempo que durou a construção da Catedral da Sé, substituiu-a como catedral da cidade de São Paulo.

O histórico dessas irmandades nos mostra de forma clara como os interesses das classes dominantes, aliados à opressão implementada pelo poder eclesiástico, aprofundou as dificuldades de integração do negro à sociedade urbana europeizada que começava a se formar em São Paulo.

Contudo, as formas de resistência e luta desses excluídos iam além da religiosidade que os unia. A ajuda aos marginalizados, o culto e o respeito aos mortos, as folias, as festas de santos, as formas de organização e a delimitação dos estatutos foram embriões das futuras associações e sociedades negras na cidade, bem como inspiraram várias lideranças na criação dos jornais que divulgaram os ideais de valorização da comunidade negra.

Clóvis Moura considera que a comunidade negra se tornou um importante grupo diferenciado dentro da sociedade competitiva que caracterizava a São Paulo do final do século XIX. Diferenciado sobretudo porque o era por outros grupos, fossem eles os imigrantes ou a elite branca aqui já estabelecida. Muito mais que um grupo diferenciado, porém, era um grupo

${ }^{103}$ QUINTÃO, Antonia Aparecida. Irmandades Negras... pp.19-22. 
específico, pois foi capaz de forjar mecanismos de resistência a fim de preservá-lo de maneira singular. Contudo, na opinião do sociólogo,

O negro somente se sente específico porque é diferenciado inicialmente pelas classes e grupos sociais brancos, fato que o leva a procurar organizar e elaborar uma subideologia capaz de manter a consciência e a coerção grupal em vários níveis. ${ }^{104}$

Essa diferenciação levou-o a buscar uma auto-afirmação característica de grupos sociais específicos, através da organização, da união e da solidariedade:

Sem possibilidade de o negro frequentar as entidades brancas, todas elas impermeáveis ou quase à sua presença, ele tinha de continuar a se organizar, num fenômeno que era apenas, em muitos aspectos, repetição do que já existia antes da abolição, quando o negro escravo, para não ser extinto social e mesmo biologicamente, organizou-se de diversas formas - confrarias, cantos, entidades de auxílio mútuo para compra de alforria, quilombos, etc. mantendo, com isso, uma série de valores e patamares de defesa interligando-se positivamente. ${ }^{105}$

Nas páginas anteriores, vimos uma das formas de defesa e resistência mencionadas por Clóvis Moura: a das Irmandades e confrarias. Outras foram os grêmios recreativos e culturais, com seus bailes, cordões, sambas e times de futebol, além dos núcleos de religião afrobrasileira (candomblé e macumba), dos grupos de capoeira e das cooperativas.

É preciso lembrar com Clóvis Moura ainda, que a essa altura - fins do século XIX e primeiras décadas do século seguinte - era significativo o número de negros em São Paulo, como mostra o quadro a seguir ${ }^{106}$ :

\footnotetext{
${ }^{104}$ MOURA, Clóvis. Sociologia do negro brasileiro. São Paulo: Ática, 1988, pp. 117 e 120

${ }^{105}$ MOURA, Clóvis. Dialética radical do Brasil Negro. São Paulo: Ática, 1994, p. 211

${ }^{106}$ Relatório apresentado ao cidadão Dr. Cesário Mota Júnior, secretário dos Negócios do Interior do Estado de São Paulo, pelo diretor da Repartição de Estatística e Arquivo dr. Antônio de Toledo Pisa, em 31 de julho de 1894 (Rio de Janeiro: Tip. Leuzinger, 1894; apud Florestan Fernandes, A Integração do Negro na sociedade de classes (3a . Ed. São Paulo: Ática, 1978), p. 23 IN: DOMINGUES, Petrônio José. Uma história não contada... p. 316.
} 


\begin{tabular}{|l|c|}
\hline \multicolumn{1}{|c|}{ Grupo Específico } & $\begin{array}{c}\text { População } \\
\text { na Cidade } \\
\text { de São } \\
\text { Paulo }\end{array}$ \\
\hline Italiano & 44.854 \\
\hline Negros (pretos e pardos) & 14.258 \\
\hline Portugueses & 14.209 \\
\hline Espanhóis & 4.727 \\
\hline Alemães & 2.320 \\
\hline Franceses & 1.107 \\
\hline Austríacos & 948 \\
\hline Outras nacionalidades & 3.303 \\
\hline
\end{tabular}

Esses dados referem-se ao censo de 1893, em que negros e pardos formavam o segundo maior grupo étnico na cidade de São Paulo e superavam em 14.9\% a soma de todas as outras nacionalidades com exceção da portuguesa, que apresentava número similar e praticamente empatava em termos de grandeza com negros e pardos. De acordo com Florestan Fernandes, o número de negros e pardos apresentou redução ao final dos anos 1910, pois representavam 9\% da população da cidade, cujo total era de pouco mais de 52.000 habitantes ${ }^{107}$

Após a abolição, os negros passaram a se concentrar no que Petrônio Domingues chamou de "bolsões" ou "territórios negros", representados pelos bairros do Bexiga, Jabaquara, Barra Funda e Lavapés. ${ }^{108}$. Mesmo assim, a maior concentração permanecia ainda nos subúrbios, conforme indica o censo de $1893^{109}$ :

\footnotetext{
${ }^{107}$ Recenseamento do Brasil realizado em 1 de setembro de 1920, Diretoria Geral de Estatística vol. IV, $1^{\mathrm{a}}$ parte (População). Rio de Janeiro: Tip. Da Estatística, 1928), pp. 856, 860, 861 e 867 IN: DOMINGUES, Petrônio José. Uma história não contada... p. 317.

${ }^{108}$ DOMINGUES, Petrônio José. Uma história não contada ... p. 319.

${ }^{109}$ Relatório apresentado ao cidadão Dr. Cesário Mota Júnior, secretário dos Negócios do Interior do Estado de São Paulo, pelo diretor da Repartição de Estatística e Arquivo dr. Antônio de Toledo Pisa, em 31 de julho de 1894 (Rio de Janeiro: Tip. Leuzinger, 1894; cf. Florestan Fernandes, A Integração do Negro na sociedade de classes... (3 ${ }^{\text {a }}$ Ed. São Paulo: Ática, 1978), p. 25 IN: DOMINGUES, Petrônio José. Uma história não contada...p. 316.
} 


\begin{tabular}{|l|l|l|l|l|}
\hline Região & Brancos & Caboclos & Pardos & Pretos \\
\hline Norte e Sul da Sé & $88.3 \%$ & $0.40 \%$ & $6.3 \%$ & $5.0 \%$ \\
\hline Santa Ifigênia & $86.4 \%$ & $0.30 \%$ & $8.9 \%$ & $4.4 \%$ \\
\hline Consolação & $89.2 \%$ & $0.70 \%$ & $5.2 \%$ & $4.9 \%$ \\
\hline Brás & $93.1 \%$ & $0.30 \%$ & $3.3 \%$ & $3.3 \%$ \\
\hline Subúrbios & $75.1 \%$ & $0.20 \%$ & $\mathbf{1 5 . 3 \%}$ & $\mathbf{9 . 4 \%}$ \\
\hline
\end{tabular}

Foi exatamente nesses bairros e áreas restritas que se formaram em maior número as entidades ligadas à comunidade negra, como as já referidas associações, grêmios e jornais. Havia uma segregação que abrangia certas praças, avenidas, ruas e até bares. Por convenção tácita, onde o negro entrava, o branco evitava entrar, e vice-versa. Entre vários pontos de frequencia assídua dos negros, podem ser mencionados a Praça João Mendes (defronte à Igreja dos Remédios), o Largo do Palácio (hoje Pátio do Colégio) ${ }^{110}$, as imediações da Praça da Sé (chamado de "trincheira negra", conforme mencionava o jornal Progresso) ${ }^{111}$, a Barra Funda, o Largo do Riachuelo, e os bares Porta Larga, no largo do Piques, o Avelino, na praça João Mendes, e o Pretalhão, na rua Barão de Paranapiacaba. ${ }^{112}$

As primeiras associações beneficentes negras do tipo a que estamos nos referindo eram uma reação à recusa das associações brancas em aceitar negros em seus quadros, bem como a necessidade de estabelecer vínculos de lazer. Basicamente, surgiam das conversas iniciais nos principais pontos de concentração já mencionados, em que alguns interessados promoviam a criação de entidades sem fins lucrativos, convertendo-as em socidades dançantes, beneficentes, cívicas, esportivas, grêmios recreativos, literários, dramáticos e cordões carnavalescos. Possuíam, na maioria das vezes, um estatuto, e eram conduzidas pela figura de um presidente, auxiliado por uma diretoria escolhida por meio de eleições. As mais estruturadas possuiam sede própria, e a principal fonte de recursos era o pagamento das mensalidades feito pelos sócios. Lançavam-se também métodos alternativos para conseguir fundos, como a arrecadação de bilheteria nos bailes, a circulação do livro de ouro e a realização de eventos beneficentes.

\footnotetext{
${ }^{110}$ LEITE, José Correia. E disse o velho militante... pp. 44-45

111 Progresso, 20 ago. 1930, p. 4.

${ }^{112}$ FLOREAL, Sílvio. Ronda da meia-noite. São Paulo: Cupolo, 1925, p. 13. IN: DOMINGUES, Petrônio José. Uma história não contada... p.324.
} 
No levantamento realizado por Petrônio José Domingues para o período de 1897 a 1930 foram encontradas 85 associações negras na cidade de São Paulo, sendo 25 dançantes, 9 beneficentes, 4 cívicas, 14 esportivas, 21 grêmios recreativos, dramáticos e literários, além de 12 cordões carnavalescos.

Já Regina Pahim Pinto encontrou entre 1907 e 1937, aproximadamente 123 dessas associações. Nesse cômputo não foram consideradas entidades exclusivamente engajadas em atividades carnavalescas e esportivas, nem aquelas fora da Capital. ${ }^{113}$

Algumas dessas associações vieram a se destacar, como o Grupo Dramático e Recreativo Kosmos, fundado em 15 de novembro de 1908, após dissidência de alguns integrantes da Sociedade 18 de Agosto. Localizava-se na rua Florêncio de Abreu, e chegou a possuir um corpo cênico, uma biblioteca e um jornal, o Kosmos.

Outra importante associação foi o Centro Cívico Palmares, criado em 29 de outubro de 1926 pelo sargento Antonio Carlos, da Força Pública, do qual trataremos mais à frente.

Quanto às associações beneficentes, também conhecidas como sociedades de socorro mútuo, foram instituições de caráter previdenciário, visavando proteger e amparar seus segurados, além de garantir-lhes alguns benefícios, como empréstimo de dinheiro, auxílio ao desempregado e aos doentes, lazer e instrução.

Para efeito de comparação, o Anuário Estatístico de São Paulo, em 1917, registrava 16 sociedade beneficentes criadas por "colônias" estrangeiras, sendo que as que representavam os italianos eram em maior número (nove) ${ }^{114}$. As negras tentaram atingir o mesmo nível de consciência étnica e organização daquelas compostas por grupos étnicos estrangeiros e surgiram pela mesma motivação: a recusa das "brancas" em admitir como sócios pessoas de cor."115

Também elas possuiam uma diretoria, eleita periodicamente, composta por presidente, secretário, procurador, tesoureiro e conselho fiscal. A principal fonte de recursos provinha do pagamento das mensalidades pelos associados e em seus estatutos, constavam atividades como assembléias, palestras, excursões, quermesses, campanhas políticas e comunitárias.

\footnotetext{
${ }^{113}$ PINTO, Regina Pahim. O movimento negro em São Paulo... p. 84, apud DOMINGUES, Petrônio José. Uma história não contada... p. 329.

${ }^{114}$ Anuário Estatístico de São Paulo de 1917, vol. 1. São Paulo, Tip. Do Diário Oficial, 1919, pp. 352-258 IN:

DOMINGUES, Petrônio José. Uma história não contada.... p. 334.

${ }^{115}$ O Getulino, 30 dez. 1923, p.1
} 
Organizavam ainda colégios, bibliotecas, fundos de pensão, assistência jurídica, centros de caridade entre outros serviços. A estrutura dessas associações será o norteador da organização dos futuros jornais da imprensa negra.

Ante o que foi dito, é possível depreender que a presença negra nas entidades referidas foi bastante importante, dado o grande número de habitantes negros da capital paulista excluído pelos outros grupos étnicos e raciais, além de estar vivendo num contexto de forte competição. Levando em consideração a nossa própria pesquisa empírica, a de Petrônio Domingues e a de Regina Pahim, foi possível fazer um levantamento cronológico das principais associações negras paulistanas, no quadro que se segue ${ }^{116}$ :

\footnotetext{
${ }^{116}$ DOMINGUES, Petrônio José. op. cit., pp. 329-341; PINTO, Regina Pahim. op. cit, p.84 IN: DOMIGUES, Petrônio José. Op. cit. pp. 329-341. A diferença entre o nosso levantamento e o realizado por Petrônio José Domingues e Regina Pahim Pinto diz respeito basicamente às datas nas quais algumas dessas associações foram criadas ou tiveram seu registro publicado. Petrônio Domingues se utiliza de dados fornecidos pela pesquisa de Regina Pahim (entre 1907 e 1937) e pela análise empírica de material fornecido pelo Diário Oficial e pelo Anuário Estatístico de São Paulo. Nossa pesquisa buscou o registro de algumas das irmandades, associações e sociedades beneficentes junto aos arquivos do $1^{\circ}$ cartório de registro de imóveis da cidade de São Paulo entre 1895 e 1927. Pressupõe-se que havia um período de tempo necessário entre o requerimento para registro da sociedade e sua publicação em documentos notariais.
} 


\begin{tabular}{|l|r|r|c|}
\hline Entidade & \multicolumn{1}{|c|}{ Fundação } & Inscrição/Data & Tipo \\
\hline Irmandade de Nossa Senhora dos Homens Pretos & $11 / 03 / 1895$ & $17(1)$ & Religiosa \\
\hline Irmandade de São Benedicto da Cidade de São Paulo & $17 / 02 / 1896$ & $23(1)$ & Religiosa \\
\hline Clube 28 de Setembro & 1897 & $(3)$ & Recreativo \\
\hline Sociedade 13 de Maio & 1902 & $(3)$ & Recreativo \\
\hline Sociedade Cooperativa dos Homens Pretos & 1902 & $1904(2)$ & Cooperativa \\
\hline Clube 13 de Maio dos Homens Pretos & $18 / 11 / 1902$ & $114(1)$ & Beneficente \\
\hline Sociedade Protectora dos Pobres & $24 / 11 / 1904$ & $160(1)$ & Beneficente \\
\hline Clube 15 de Novembro & 1907 & $(3)$ & Beneficente \\
\hline Sociedade Beneficente dos Homens de Cor & $08 / 01 / 1909$ & $254(1)$ & Beneficente \\
\hline Associação Beneficente Amigos da Pátria & $13 / 05 / 1908$ & $19 / 11 / 1909(2)$ & Beneficente \\
\hline Club Dançante 20 de Julho & $21 / 10 / 1911$ & $339(1)$ & Beneficente \\
\hline Clube Recreativo Paulistano & 1912 & $(3)$ & Beneficente \\
\hline Sociedade Internacional Beneficente de Chauffeurs do & $27 / 5 / 1912$ & $358(1)$ & Beneficente \\
E.SP & & & \\
\hline Centro de Federação dos Homens de Cor de São Paulo & $04 / 09 / 1914$ & $431(1)$ & Beneficente \\
\hline Sociedade Beneficente Grupo 13 de Maio & $13 / 05 / 1915$ & $13 / 4 / 1924(2)$ & Beneficente \\
\hline Grupo Recreativo 6 de Maio & 1917 & $(3)$ & Beneficente \\
\hline Brinco das Princesas & 1917 & $(3)$ & Beneficente \\
\hline Associação dos Homens Unidos & 1917 & $20 / 3 / 1917(2)$ & Beneficente \\
\hline Sociedade Beneficente Feminina Arte Culinária & 1920 & $1920(2)$ & Beneficente \\
\hline Grêmio Dramático Recreativo Kosmos * & 1908 & $02 / 12 / 1921-837(1)$ & Beneficente \\
\hline Grupo Recreativo Princesa do Norte & 1921 & $(3)$ & Beneficente \\
\hline Centro Recreativo da Liberdade & $15 / 03 / 1922$ & $865(1)$ & Beneficente \\
\hline Centro Humanitário José do Patrocínio & $11 / 10 / 1923$ & $994(1)$ & Beneficente \\
\hline Sociedade Dansante 28 de Setembro & $10 / 11 / 1924$ & $1087(1)$ & \\
\hline Centro Recreativo Smart & $26 / 01 / 1925$ & $1101(1)$ & \\
\hline Centro Cívico Palmares & $28 / 12 / 1926$ & $1304(1)$ & \\
\hline Grêmio Recreativo Brasil Político dos Homens de Cor & $23 / 06 / 1927$ & $1344(1)$ & \\
\hline
\end{tabular}

Notas:

(1) Número de Inscrição no $1^{\circ}$ Cartório de Imóveis da Cidade de São Paulo (fonte: Arquivo do Estado)

(2) Ano de publicação no Diário Oficial do Estado de São Paulo - Petrônio Domingues e Regina Pahim

(3) Trabalho de Regina Pahim Pinto ${ }^{117}$

* O Grêmio Dramático Recreativo Kosmos foi criado em 1908 mas o registro de sua sede consta de 1921.

É importante destacar que o foco do presente trabalho não incide sobre tais associações ou sobre a resistência de escravos e libertos no período anterior à Abolição, como foi visto nas páginas até aqui registradas. Daí não detalharmos nem aprofundarmos esses temas, embora sejam reações ou à escravidão ou à exclusão sócio econômica pós-libertação.

Nosso objetivo é o de destacar outra forma de reação à exclusão: aquela constituída pela Imprensa. Através dela, que não deixa de ser uma manifestação coletiva, poderemos detalhar com mais vagar a atuação dos negros através dos vários meios de que puderam dispor, como por exemplo o movimento negro, partidos políticos, conflitos internos, etc.

${ }^{117}$ PINTO, Regina Pahim. op, cit, p.84 apud DOMINGUES, Petrônio José. op. cit. p. 329 


\section{Capítulo 3 - Novas reações coletivas à exclusão: os primeiros jornais}

A historiografia brasileira registra inúmeros trabalhos de jornalistas e publicistas do século XIX, que levantaram questões e debates sobre a situação do negro no Brasil. Entre eles Machado de Assis, Luiz Gama, José do Patrocínio e o jurista baiano Antonio Pereira Rebouças. Além do caráter político e literário, foram manifestações sobre experiências, luta e resistência de grupos que representavam interesses da população negra. Uma dessas formas de manifestações se concretizou no aparecimento de pasquins e jornais direcionados a esse grupo, conhecidos no seu conjunto por imprensa negra.

Nosso entendimento sobre o que é Imprensa Negra, compreende o conjunto de jornais criados e mantidos por pessoas negras, direcionados ao público negro para o atendimento de expectativas específicas em defesa de seus interesses.

Cabe lembrar que, apesar do primeiro momento importante dessa imprensa em São Paulo ter ocorrido, segundo pensamos, em 1915, justificando o início de nosso balizamento histórico, outros estudos apontaram a existência de jornais voltados para a comunidade afrodescendente, antes e depois da Abolição.

Dentro das pesquisas realizadas, o primeiro jornal desse gênero no Brasil foi $O$ Homem de Côr, surgido na Tipografia Fluminense, de Francisco Paula Brito. Em pleno período escravista, foi o primeiro de uma série de periódicos negros surgidos na capital do Império. Seu número inicial foi à ruas em 14 de setembro de 1833, portanto, dois anos após a abdicação de D. Pedro I e na data da criação da Guarda Nacional.

Em destaque, no lado esquerdo, havia a transcrição do parágrafo 14 do artigo 179 da Constituição de 1824, que diz: “Todo o Cidadão pode ser admitido aos cargos públicos civis, políticos e militares, sem outra diferença que não seja a de seus talentos e virtudes". No direito, reproduz literalmente o seguinte trecho de um ofício de Manuel Zefereino dos Santos, então Presidente da Província de Pernambuco, de 12 de junho de 1833:

"O Povo do Brasil he composto de Classes heterogeneas, e debalde as Leis intentem mistural-as, ou confundil-as, sempre alguma hade procurar, e tender a separar-se das outras, e eis hum motivo mais para a eleição recair nas classes mais numerosas". 118

\footnotetext{
${ }^{118}$ PINTO, Ana Flávia Magalhães. De pele escura e tinta preta... p.17.
} 
Manifestos em prol da população negra não eram novidade. Em 1798, por ocasião da Revolta dos Búzios em Salvador, negros e pobres utilizaram como veículo de transmissão de suas ideias, manifestos colados em paredes da cidade, o que hoje seria um "jornal mural"119.

Tipógrafo e jornalista negro, Francisco de Paula Brito (1809-1861) iniciou carreira como aprendiz de arte gráfica na Tipografia Imperial e Nacional, ex-Impressão Régia, por intermédio de seu avô materno, Martinho Pereira de Brito, ex-comandante do $4^{\circ}$ Regimento de Milicianos, denominado Regimento dos Pardos, de onde saiu reformado como sargentomor. Paula Brito passou ainda pela Tipografia de R. Ogier e pela de Seignot-Plancher, fundador do Jornal do Comércio. Conseguiu o maquinário para início dos trabalhos em $1831^{120}$.

Em 1833, com a colaboração de Maurício José de Lafuente, uma sequência de jornais negros surgia no Rio de Janeiro: $O$ Homem de Côr (Tipografia Fluminense de Brito - n.1: 14 de setembro; n.2: 28 de setembro), O Crioulinho (Tipografia do Diário - a partir de 30 de setembro); $O$ Mulato (Tipografia Fluminense de Brito - n.3: 16 de outubro; n.4: 23 de outubro; e n.5: 4 de novembro); Brasileiro Pardo (Tipografia Paraguassu - n.1: 21 de outubro); $O$ Cabrito (Tipografia Miranda e Carneiro - n.1: 7 de novembro; e n.2: 20 de novembro); e $O$ Lafuente (Tipografia Paraguassu - n.1: 16 de novembro) . O teor dos editoriais era a denúncia contra o preconceito, a opressão e as arbitrariedades cometidas na capital do Império contra as pessoas de cor. O tom do discurso era incisivo e provocativo, sendo que alguns desses periódicos, como O Homem de Côr e o Brasileiro Pardo eram relacionados a movimentos políticos, como por exemplo aqueles partidários do movimento restaurador e membros ligados ao Partido Exaltado (Paulo Brito era um deles). ${ }^{121}$

Em 13 de janeiro de 1876, no Recife, era publicado o primeiro dos doze números do semanário O Homem - Realidade Constitucional ou Dissolução Social. O local era a

\footnotetext{
${ }^{119}$ Também conhecida como "Conjuração Baiana", "Revolta dos Alfaiates" ou "Revolta das Argolinhas". Os integrantes eram basicamente negros e pobres que, inspirados pelos ideais de liberdade e igualdade da Revolução Francesa, pretendiam proclamar a república e abolir a escravidão, em um momento que os ecos da Revolução Haitiana se faziam ouvir no Brasil. Identificavam'-se através de um búzio preso ao pulso ou à orelha, e também pelo fato de alguns revoltosos exercerem a ocupação de alfaiate. Os búzios seriam utilizados como moeda de troca na nova república, a exemplo do que ocorria em alguns países africanos. Sobre a Revolta dos Búzios, ver LOPES, Nei. Enciclopédia Brasileira da Diáspora Africana. São Paulo: Selo Negro, 2004; TAVARES, Luís Henrique Dias. História da Bahia (10a. ed.). São Paulo: Editora UNESP; Salvador (BA): EDUFBA, 2001.

${ }^{120}$ GONDIM, Eunice Ribeiro. Vida e obra de Paula Brito: iniciador do movimento editorial no Rio de Janeiro (1809-1861). Rio de Janeiro: Livraria Brasiliana, 1965, p. 17.

${ }^{121}$ Maiores detalhes, ver VIANNA, Hélio. Contribuição à história da imprensa brasileira (1812-1869). Rio de Janeiro: Imprensa Nacional, 1945 e MATTOS, Hebe Maria. Escravidão e cidadania no Brasil Monárquico. Rio de Janeiro: Jorge Zahar Editor, 2000.
} 
Tipografia Correio do Recife, situada no pátio da Matriz de Santo Antônio nº 15, na Praça da Independência. Logo em sua apresentação, o tom era de inquietação e frustração:

Há tempo de calar e há tempo de falar. O tempo de calar passou, começou o tempo de falar.

A classe dos homens de cor, sem dúvida nenhuma, a mais numerosa e a mais industriosa do Brasil, parece atualmente voltada ao ostracismo pelos homens que nos governam, contra toda a justiça, contra a própria lei fundamental do país.

Embora os particulares tratem-nos com as atenções merecidas, embora muitos deles se achem ligados conosco pelos laços da mais sincera amizade, todavia os fatos denunciam que o partido que há tempos predomina na província parece manter o propósito desleal de ir apartando dos empregos públicos aqueles nossos que para eles haviam sido nomeados por consideração de seus talentos e virtudes, conforme preceitua a Constituição do Império. ${ }^{122}$

A ordem é protestar e confrontar, principalmente em relação às ações das elites que insistem em não respeitar os direitos dos libertos, depois da proibição do tráfico e da promulgação da Lei do Ventre Livre, e mesmo daqueles negros que ainda estavam escravizados. A reivindicação da cidadania era apresentada de forma direta pelo jornal:

Queremos a efetiva realização da igualdade constitucional para todos os brasileiros, qualquer que seja a classe a que pertençam; queremos como um direito que nos é outorgado pela própria natureza e reconhecido pela lei fundamental do país aquilo a que a uns tem sido até hoje absolutamente recusado, e a outros dado somente a modo de favor ou antes de esmola; queremos que os indivíduos que têm cor mais escura não sejam, somente por isso, considerados como inferiores aos que têm a cor mais clara, como se a cor, qualquer que ela seja, por si pudesse dar ou tirar merecimento a alguém; queremos a extinção total da escravidão no Brasil, [único país do mundo em que tão reprovada instituição ainda desgraçadamente existe. ${ }^{123}$

Na página principal, encontrava-se a inscrição "Liberdade-Igualdade-Fraternidade", inicialmente ao centro do cabeçalho. Já nos primeiros números, passa a emoldurar o título do jornal: “O Homem: Realidade Constitucional ou Dissolução Social”. À direita, era possível ler: "LIBERDADE: Nenhum cidadão pode ser obrigado a fazer ou deixar de fazer alguma coisa senão em virtude da lei. Const. Art. 179 § 1". À esquerda, estava escrito: "FRATERNIDADE: Aquele que tem ódio a seu irmão está em trevas e anda nas trevas, e não sabe por onde vai porque as trevas cegaram seus olhos. São João. Ep. I, cap. II v. II’. Ao centro, entre as essas duas inscrições, lia-se: "IGUALDADE: Todo cidadão pode ser admitido em cargos públicos, civis, políticos ou militares sem outra diferença que não seja a dos seus talentos e virtudes. A lei será igual para todos quer proteja quer castigue, e recompensará em

\footnotetext{
${ }^{122}$ O Homem, n.1, p. 1. IN: PINTO, Ana Flávia Magalhães. op.cit., p.87.

${ }^{123}$ O Homem, n.4, p.2. IN: PINTO, Ana Flávia Magalhães. op. cit., p.90.
} 
proporção dos merecimentos de cada um. Const. Art. 179, § XIII e XIV". ${ }^{124}$ Este último constava também no cabeçalho de $O$ Mulato ou O Homem de Côr.

De acordo com Ana Flávia Magalhães Pinto, já citada, o jornal foi publicado entre 13 de janeiro e 30 de março de 1876, em periodicidade semanal, sempre às quintas-feiras. As assinaturas eram concedidas mediante pagamento antecipado, no valor de $2 \$ 000$, por três meses. Para o assinante que tomasse duas assinaturas, o pagamento era de $3 \$ 000$ por igual período. Cada anúncio publicado por assinante custava $2 \$ 000$ por coluna. O jornal também acolhia publicações de particulares, com preço a tratar. ${ }^{125}$

Ainda houve, entre os primeiros jornais da imprensa negra no Brasil, a publicação de O Exemplo, o pioneiro entre os periódicos negros do Rio Grande do Sul. Um grupo de homens negros, entre eles o diretor de redação Arthur de Andrade, o editor-chefe Marcílio Freitas, os colaboradores Aurélio Bittencourt Júnior, Sérgio Bittencourt e Alfredo de Souza, além do barbeiro, jornalista e escritor Esperidião Calisto, fundou-o em 11 de dezembro de 1892, numa barbearia da então Rua da Praia n. 247, também conhecida por Rua dos Andradas, no centro de Porto Alegre. ${ }^{126}$

As publicações de $O$ Exemplo duraram 37 anos, tendo percorrido algumas fases, com notada intermitência. A primeira fase durou de 1892 a 1895; a segunda, vai de 1902 a 1905; a terceira, nos anos de 1910 e 1911, e a última, entre 1916 e 1930. Comparado à duração média dos jornais pertencentes à imprensa negra no país, trata-se de um período extraordinário, confirmando a capacidade de persistência, resistência e luta dos negros, principalmente se levarmos em consideração o contexto histórico e o locus nos quais os jornais estavam inseridos.

O tema principal do número de estréia era o combate ao preconceito e à discriminação raciais:

Devemos mostrar à sociedade que também temos um cérebro que se desenvolve segundo o grau de estudo a que o sujeitemos e, por consequencia, que também nos podemos alistar nas cruzadas empreendidas pela inteligência, muito embora algum estulto nos queira acoimar, ou seja porque desconheça as nossas legítimas aspirações, ou seja porque faça parte dos doutrinários que julgam o homem pela cor da epiderme. ${ }^{127}$

\footnotetext{
${ }^{124}$ O Homem, n. 1-12, p.1

${ }^{125}$ PINTO, Ana Flávia Magalhães. op. cit., p. 96

${ }^{126}$ DORNELLES, Beatriz. Porto Alegre em destaque: história e cultura. Porto Alegre: EDIPUCRS, 2004 , p.48

${ }^{127}$ O Exemplo, n.1, p. 1 IN: PINTO, Ana Flávia Magalhães. Op. Cit., 158.
} 
A oposição ao racismo e à discriminação será tema recorrente na grande maioria das publicações do periódico gaúcho, bem como as críticas ao governo e as dificuldades enfrentadas por aqueles que mantinham o desejo de ascensão social.

Ao nos debruçarmos sobre a pesquisa de Ana Flávia Magalhães Pinto sobre jornais negros do período oitocentista, encontramos dois periódicos publicados em São Paulo no período pós abolição: A Pátria, de 2 de agosto de 1889, e $O$ Progresso, de 24 de agosto de 1899. ${ }^{128}$ Ambos carregavam em seu subtítulo a inscrição orgam dos homens de côr. Mesmo tendo sido analisados apenas dois exemplares desses jornais, acreditamos que o resultado obtido foi significativo, pois as características e material encontrados são bastante emblemáticos diante do contexto histórico e das representações sobre o negro na cidade.

O jornal A Pátria, criado pelo tipógrafo abolicionista Inácio Araújo Lima, homenageava em suas primeiras edições, à primeira página, os grandes abolicionistas. Seu segundo número trazia a estampa do busto de Visconde do Rio Branco (in memoriam) e homenageava Feliciano Bicudo e Fernando de Albuquerque, companheiros de Araújo Lima em campanhas abolicionistas. Foi a primeira vez em que houve o uso de imagens na diagramação de jornais da imprensa negra, de acordo com a pesquisadora.

O reconhecimento do direito à cidadania e a valorização do negro como protagonista na história do Brasil, e especificamente de São Paulo, eram abordados na segunda edição do jornal:

Chama-nos paulistas porque tivemos nosso berço na cidade de São Paulo, legendária e heróica pelos brilhantes feitos de seus filhos, porém nós que somente podemos dizer: Aqui nesta parte da América do Sul, tivemos nosso berço, mas onde está nossa Pátria? ${ }^{129}$.

Todos os assuntos relativos à correspondência, assinaturas e artigos eram direcionados à Casa Aymoré, situada no Largo da Sé, n. 2D. A Pátria foi o primeiro jornal a reservar um espaço para uma tira publicitária (em sua segunda edição, publicava um anúncio da Charutaria Aymoré). ${ }^{130}$

\footnotetext{
${ }^{128}$ Idem, ibdem, p. 135

${ }^{129}$ A Pátria, n. 2, p.2 IN: PINTO, Ana Flávia Magalhães. Op.cit., p. 142

${ }^{130}$ DOMINGUES, Petrônio José. A nova abolição. São Paulo: Summus, 2008, p.19.
} 
Em 24 de agosto de 1899 era criado o jornal O Progresso, tendo à frente Theophilo Dias de Castro (redator chefe) e José Cupertino (redator secretário). Sua sede estava estabelecida à Rua das Flores, 45, e sua impressão era realizada na Tipografia Soler, à Rua del Riachuelo n. 34. Sua primeira página estampava a xilogravura de Luiz Gama, e a data de sua criação coincidia com o aniversário de sua morte. Sua trajetória de vida era ressaltada como um exemplo a ser seguido pelos patrícios de São Paulo:

Pretos! É preciso que se pague este tributo ao morto ilustre: é preciso que seu nome brilhe dentro de nossas almas, tanto quanto a estrela mais adorada do Firmamento; é preciso que a aurora do século XX, ao saudar este pedaço do continente americano, onde se acham sepultados os restos de nossos maiores, bem haja o nosso sometimento nessa ânsia de progredir; que dele se desprenda o retalho de torpezas que se apega ao manto velho do século XIX, sendo atirado à noite do esquecimento; que uma geração capaz, ativa e feliz surja triunfante na conquista do Bem, na realização dos nobre ideais.

E para isso é necessário que não demoremos em construir o nosso núcleo social, no qual fiquem concentradas todas as nossas forças, derivando dele as boas intenções que temos em prestar o nosso auxílio desinteressado à raça a que pertencemos. ${ }^{131}$

No espaço urbano, as queixas contra a ordem dominante são severas:

Proclamou-se a República, o governo da igualdade, da fraternidade e queijamas (sic) liberdades. No movimento republicano, contavam-se muitos pretos e mulatos (que vêm a dar no mesmo) que prestavam e prestam serviços inolvidáveis ao novo regime.

Esperávamos nós, os negros, que, finalmente, ia desaparecer para sempre de nossa pátria o estúpido preconceito e que os brancos, empunhando a bandeira da igualdade e fraternidade, entrassem em franco convívio com os pretos, excluindo apenas os de mau comportamento, o que seria justíssimo.

Qual não foi, porém, a nossa decepção ao vermos que o idiota preconceito em vez de diminuir cresce; que os filhos dos pretos, que antigamente eram recebidos nas escolas públicas, são hoje recusados nos grupos escolares; e que os soldados pretos que nos campos de batalha têm dado provas de heroísmo, são postos, oficialmente, abaixo do nível de seus camaradas; que para os salões e reuniões de certa importância, muito de propósito não é convidado um só negro, por maiores que sejam seus merecimentos; que os poderes públicos em vez de curar do adiantamento dos pretos, atira-os à margem, como coisa imprestável? ${ }^{132}$

O que nos chamou a atenção durante a leitura da pesquisa de Ana Flávia Pinto sobre a imprensa negra no período oitocentista é que, em plena vigência do período escravista, esses periódicos convocavam a população negra a refletir denúncias a respeito de racismo e cobravam as mesmas oportunidades de ascenção e mobilidade social, pleiteavam o acesso a cargos públicos e a valorização do pensamento do homem negro. Isso continuou a ocorrer,

${ }^{131}$ O Progresso, n.1. p. 1 IN: PINTO, Ana Flávia Magalhães. op.cit., p. 149

132 PINTO, Ana Flávia Magalhães. op.cit., p.27 
mesmo com a adaptação ao republicanismo, seja através de esperanças renovadas, seja por meio da frustração por promessas não cumpridas.

A observação mais cuidadosa do teor desses jornais, em que pese sua descontinuidade, coloca em discussão o conceito de alguns autores, como Roger Bastide e Florestan Fernandes, de que haveria uma quase total anomia por parte dos representantes do grupo sócio-racial negro. Entendemos que todas as iniciativas em prol de uma organização de pensamentos voltadas à ação e à resistência contra a ordem dominante são realmente visíveis e concretas.

Entretanto, não podemos deixar de considerar que os exemplares existentes dos jornais O Homem de Cor, O Mulato, O Homem, A Pátria, Progresso e O Exemplo não nos permitem caracterizá-los totalmente como instrumentos emancipados da consciência negra em seus estados de origem, dado o caráter incisivo de seus editoriais e suas reivindicações em tempos de escravidão e início de período republicano. Porém, podemos certamente estimar que as expectativas de seus redatores eram de mobilização da população negra e da esperança de tempos de mudança, com o anseio por ações efetivas e o respeito aos direitos básicos do negro como cidadão brasileiro.

Após 1899, encontramos menção a outros jornais, cuja informação se nos apresentou de forma limitada: entre 1903 e 1904 foi publicado $O$ Baluarte, pertencente ao Centro Literário dos Homens de Cor da cidade de Campinas, fundado pelo jornalista Benedito Florêncio e por Francisco José de Oliveira; em 1907, foi encontrada informação sobre $O$ Propugnador, criado na cidade de São Paulo, sendo órgão vinculado à Sociedade Propugnadora 13 de Maio; entre 1911 e 1916 circulou A Pérola, periódico fundado por Benedito Prestes, um funcionário da Companhia de Gás de São Paulo, e que pertencia à Sociedade Recreativa XV de Novembro; O Combate, criado em 1912 em Campinas, é apresentado de forma bastante restrita nos trabalhos pesquisados. O fato relevante é que foi por algum tempo dirigido por Lino Guedes, poeta, escritor, jornalista e um dos maiores expoentes da imprensa negra no século $\mathrm{XX}$, tendo sido fundador e redator chefe de $O$ Getulino (1923), diretor de O Maligno (1924), ambos fundados em Campinas, e mais tarde editor de O Progresso (1928), de São Paulo, sem falar de sua notável colaboração junto a diversos outros jornais, tanto da imprensa negra como da "grande imprensa". Outro jornal de importante circulação e colaboração com jornais negros de São Paulo foi O Patrocínio, criado em Piracicaba pelo dr. Olímpio Gentil de Arruda, em 1913. Em 1915 foram encontrados dois jornais na capital paulista: Binóculo, criado por um grupo de rapazes da Barra Funda e 
chefiados um por um Teófilo Camargo, um alfaiate, e Princeza do Oeste. Contudo, não foram encontrados exemplares desses dois jornais junto às fontes pesquisadas. ${ }^{133}$

Em nossas pesquisas ainda encontramos informações sobre outro jornal, chamado Princesa do Norte, em depoimento de Jayme de Aguiar, um dos fundadores do jornal Clarim da Alvorada, em meados dos anos $1920^{134}$ :

(...) Havia também A Princesa do Norte. A Princesa do Norte era um jornal feito com muito carinho, com muitas dificuldades, por um preto que era cozinheiro do antigo Instituto Disciplinar, onde é o Pro-Menor. E esse cozinheiro chamava-se Antônio dos Santos e tinha um pseudônimo que os senhores vão rir: Tio Urutu. Era um preto gordo, cabelos grandes, um boné ao lado, morava na mesma rua em que eu morava. Rua Ruy Barbosa, uns dois quarteirões após a minha casa. Todas as manhãs ele passava com a sua cesta, fazia as compras que ia levar para o Instituto Disciplinar. Um dia ele me disse: "o senhor já leu o jornal?" e me mostrou $A$ Princesa do Norte. Eu gostei do jornalzinho. Vi aquelas críticas e vi uns versos. E como todos nós brasileiros, não há quem não goste de música, não há quem não goste de poesia, começamos a publicar alguma coisa no jornal do Tio Urutu. Depois, com o aparecimento do nosso jornal, Tio Urutu continuou com o seu A Princesa do Norte e depois acabou o seu bairro e acabou o seu jornal; surgiu O Clarim da Alvorada que, no início, era um jornal de cultura, instrutivo, etc., e apareceram os primeiros literatos negros dentro do nosso meio". ${ }^{135}$

Ao que tudo indica, e pelo cruzamento realizado entre as fontes, os nomes Princeza do

Oeste e Princesa do Norte se referem ao mesmo jornal, provavelmente resultado de uma confusão nos depoimentos tomados por Clóvis Moura e Miriam Nicolau Ferrara. A pesquisadora obteve a seguinte declaração de José Correia Leite:

O Tio Urutu, não me lembro o nome dele. Tinha um jornal, o "Princeza do Oeste", que era um jornal de críticas, um jornal de lavar roupa suja. Ele tinha um grupo que o ajudava...Então, as moças que se diziam recatadas, ele descobria certos podres e publicava. Vivia sempre fugido, porque todo mundo queria bater nele. Até que ficou famoso como o Tio Urutu. Era cozinheiro do Instituto Disciplinar. Gostava de fofocas e de criar casos". 136

$* * *$

\footnotetext{
${ }^{133}$ Maiores detalhes, ver PINTO, Regina Pahim. op. cit.; DOMINGUES, Petrônio José. Uma história não contada... e A nova abolição...; sobre Lino Guedes, ver arquivos do CEDAP- Unesp , disponíveis em <http://www.assis.unesp.br/cedap/cat_imprensa_negra/biografias/lino_guedes.html>, Acesso 13 jun. 2009; arquivos do Instituto Cultural Portal Afro, disponíveis em < http://www.portalafro.com.br/linoguedes.htm>, acesso 13 jun. 2009; e arquivos da Fundação Cultural Palmares, disponíveis em 〈http://www.palmares.gov.br/003/00301009.jsp?ttCD_CHAVE=466>, acesso 13 jun. 2009.

${ }^{134}$ Não temos conhecimento da existência de exemplares para pesquisa.

${ }^{135}$ Depoimento gravado em 15 de junho de 1975 por Clóvis Moura. IN: MOURA, Clóvis. Sociologia do negro brasileiro... p. 207.

${ }^{136}$ Depoimento pessoal. IN: FERRARA, Miriam Nicolau. op. cit., p. 53.
} 
No entanto, iniciaremos nossa análise, especificamente sobre os jornais da imprensa negra da cidade de São Paulo, a partir de O Menelik, seguindo a abordagem de autores como Roger Bastide, Miriam Nicolau Ferrara, Clóvis Moura e tantos outros pesquisadores que se debruçaram em teses e dissertações sobre esses periódicos. Temos a mesma opinião dos referidos acadêmicos, não no sentido de parafraseá-los mas, segundo a nossa constatação de que $O$ Menelik reunia, à época de sua primeira publicação, a maior parte dos elementos que seriam característicos dessa imprensa nos anos vindouros, por sinal, aqueles de maior efervecência para o movimento negro em São Paulo na primeira metade do século XX. Todos os outros jornais que se lhe seguiram deram continuidade a seus ideais, seja no quesito informativo, seja no sentido reivindicatório e político, além do fato de que parcela significativa do teor desses jornais já estava presente nas publicações oitocentistas.

O que torna $O$ Menelik especial é o contexto no qual sua primeira publicação está inserida. Estamos em 1915, e tanto o Brasil quanto o mundo apresentam sinais de profundas e significantes mudanças, como nos conta Roger Bastide:

Sente-se que a guerra, divulgando as ideias de liberdade e igualdade, apresentandose como o grande combate da democracia, despertou nas massas trabalhadoras de cor aspirações por melhor sorte. Ao mesmo tempo, temos aí indícios dos primeiros efeitos da política de educação no Brasil, o resultado do magnífico esforço da República no desenvolver do ensino gratuito primário.(...) $)^{137}$

A tríade do iluminismo "liberdade, igualdade e fraternidade" volta à cena e renova sentimentos de esperança para os menos favorecidos, os excluídos e marginalizados, e o negro, sobretudo em São Paulo, faz parte desse numeroso grupo. Mudanças nas políticas educacionais se fazem também sentir, e serão parte fundamental do discurso dos jornais da imprensa negra como mola propulsora para a desejada mobilidade social, tal qual poderemos ver mais adiante. Naquela época, São Paulo já começava a se destacar no cenário industrial brasileiro, à frente do Rio de Janeiro, tornando-se símbolo nacional de modernidade, pujança e desenvolvimento.

A primeira edição de $O$ Menelik - Orgam noticioso, literário e crítico dedicado aos homens de cor - tornou-se pública em 17 de outubro de 1915:

Fundou-se então este jornal o qual buscou adquirir um nome, que não deveria, mas era esquecido dos homens de côr, é esse nome o de Menelik II, o grande rei da raça

\footnotetext{
${ }^{137}$ BASTIDE, Roger. A Imprensa Negra do Estado de São Paulo... p. 50. IN: FERRARA, Miriam Nicolau. op. cit., p.39.
} 
preta, falecido em 1913. Surgiu então a fundacção deste jornal com a denominação de "O Menelik". ${ }^{138}$

O nome do jornal era uma homenagem a Menelik II ${ }^{139}$, imperador da Abssínia (atual Etiópia), que viveu entre 1844 e 1913, e que em 1896 expulsou os italianos daquele país. Ao tornar-se vitorioso e garantir a soberania sobre seu território, ao mesmo tempo em que delimitava fronteiras com Somália e Sudão, juntamente com França e Reino Unido, Menelik colocava em xeque as convicções imperialistas européias a respeito da superioridade branca sobre as demais etnias, principalmente a africana. Seu sucesso, além do aspecto bélico, foi ponto de partida para diversas representações, inclusive no Brasil. Conforme relatou José Correia Leite, que viveu grande parte de sua vida entre os italianos do bairro paulistano do Bexiga, os negros, principalmente em São Paulo, eram apelidados por aqueles de "meneliks", certamente em tom pejorativo. ${ }^{140}$

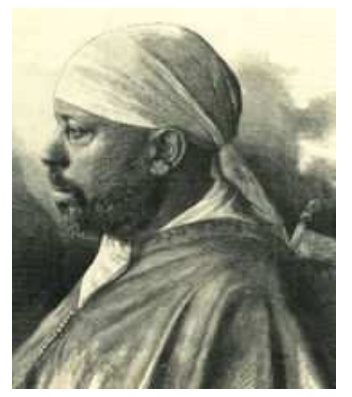

Figura 2

Menelik II

Conforme mencionado anteriormente, a admiração pela nação etíope era bastante forte em São Paulo, principalmente por força da atuação da Irmandade de Santa Efigênia e Santo Elesbão. Na Bahia, Menelik era assunto de polêmica em temas que envolviam grupos culturais negros, a criação da Embaixada Africana e até a Revolta dos Malês, chegando a ser analisada por Nina Rodrigues. No entanto, essa discussão foge ao escopo de nossa pesquisa. $^{141}$

\footnotetext{
${ }^{138}$ O Menelik, 17.10.1915, n.1, p.1

${ }^{139}$ Menelik II (cujo nome de batismo era Sahle Mariam), ras da Província Real do Choa (Shewa, em Inglês), foi Imperador da Etiópia entre 1889 e 1913, ano de sua morte, fundador da atual capital do país e um dos responsáveis por sua moderna reunificação territorial. Para maiores informações, ver MARCUS, Harold G. The Life and Time of Menelik II - Ethiopia (1844-1913). Oxford, Clarendon Press, 1975.

${ }^{140}$ José Correia Leite, depoimento pessoal. IN: FERRARA, Miriam Nicolau. Op. Cit., p. 52.

141 Ver ALBUQUERQUE, Wlamyra Ribeiro de. Esperanças de Boaventuras: Construções da África e Africanismos na Bahia (1887-1910). Estudos Afro-asiáticos, ano 24, n.2, 2002, pp. 215-245. Disponível em <http://www.scielo.br/pdf/eaa/v24n2/a01v24n2.pdf> . Acesso 13 jun. 2009.
} 
O jornal $O$ Menelik foi fundado por Deocleciano Nascimento em reunião realizada em sua residência, à Rua da Graça n. 207, em 18 de junho de 1915. Trabalhando inicialmente como fundidor em São Paulo, formou-se em Comércio pelo Lyceu Salesianos, recebendo o grau de guarda-livros, em 1919. Além de responsável por esse periódico, Deocleciano foi redator do Auriverde, redator e diretor de A Voz da Raça (foi de sua responsabilidade a redação do primeiro número, em 18 de março de 1933), e colaborador de outros jornais, entre eles Elite, O Clarim da Alvorada e Kosmos.

Os objetivos do jornal eram informados a seus leitores em nota na primeira página:

\section{DESTINO}

Como resa no cabeçalho deste jornalsinho: Orgam mensal, noticioso, critico e literario dedicada aos Homens de Cor, é necessario agora que o leitor compreenda que é o destino que cada uma destas palavras tomam, ou função que exercem.

a) E' mensal, porque destina aparecer de mez a mez.

b) E' noticioso para travarmos conhecimentos de factos que se dão e passam sem previo conhecimento da classe nossa.

c) E' critico (só entre a classe) para colher os ditos philosophicos que navegam nos nos (sic) labios desse povo.

d) E' literario para mostrar ao mundo as sabedoria (sic) que occultamente vaguea no cerebro da classe.

e) E' dedicada aos homens de cor para prestar-lhe, homenagens. ${ }^{142}$

Entende-se que o jornal visava promover discussões pertinentes ao cotidiano da cidade, mas restritas aos membros da classe ${ }^{143}$, ao mesmo tempo em que divulgava temas culturais e literários.

O jornal não era vinculado a nenhuma associação, clube ou sociedade recreativa. Em seus dizeres, "o Menelik não tem proprietário, é uma socidade composta de illimitados socios, que todos fazem por um e um faz por todos"144.

Além do redator-chefe Deocleciano Nascimento, o periódico negro mantinha estrutura administrativa bem definida: um redator secretário (Geralcino de Souza), um presidente (Reginaldo Maximo Gonçalves), um secretário (Otaviano Ferraz), um tesoureiro (Marceano Marques de Oliveira), um procurador geral (Paulo de Souza Lima), três repórteres (Theofilo

\footnotetext{
${ }^{142}$ O Menelik, 17.10.1915, n.1, p.1. Grifo nosso.

${ }^{143}$ Nas publicações pesquisadas, os termos "classe" e "raça" referem-se frequentemente à população negra.

${ }^{144}$ O Menelik, 17.10.1915, n.1, p.1
} 
Gonçalves de Freitas, José Luiz Sampaio e José Paulino), um representante no Rio de Janeiro (Octaviano José dos Prazeres) e outro em Campinas (Antenor Egydio).

Sua assinatura era semestral, ao custo de $1 \$ 500$, com pagamento antecipado. Contudo, sua descontinuidade já se fazia anunciar na página da primeira edição: “Communicamos que, O Menelick apparecerá novamente no dia 1 de janeiro do anno vindouro, aonde circulará firmemente mensal, devendo apparecer no primeiro domingo de cada mez ${ }^{145,}$.

Supomos que sua periodicidade, desde o início, era para ser mensal. Com efeito, a irregularidade na publicação, principalmente por motivos financeiros, era uma constante em jornais dessa imprensa. Todos os assuntos deveriam ser direcionados à Rua da Graça n. 203, então residência do redator-chefe, Deocleciano Nascimento. ${ }^{146}$

Outra característica desses periódicos era a imprecisão gerada por erros de tipografia ou ortografia, dada a precariedade dos recursos utilizados na impressão, o tempo disponível para avaliação dos artigos e das matérias enviadas para publicação e o nível de supervisão e revisão dos mesmos. O exemplar de 1 de janeiro de 1916 saiu como sendo o de número 3, quando na verdade tratava-se do exemplar número 2. Prova disso é a nota direcionada às mulheres, um público alvo e caro à redação do periódico:

\begin{abstract}
LEITORAS
O Menelik depois de passar quarenta dias sem o carinhoso affecto de vossas mãos delicadas - o berço gentil de sua alma, teve saudades de vós. E voltando novamente, aninhando-se ao lado da generosidade - belleza feminina, eil-o.

Eil-o jurando que d'ora avante virá todos os primeiros Domingos de cada mez trazervos trazervos (sic) novidades das estrellas e espera ser recebido com os habituados e graciosos sorrisos de vossos labios de rosas! Emquanto que o seu humilde redactor atira aos vossos mimosos pés mil beijos de gratidão. ${ }^{147}$
\end{abstract}

Entendemos que $O$ Menelik não foi apenas um marco entre os jornais da imprensa negra de São Paulo e do Brasil. Mesmo respeitando o parecer de alguns autores, para os quais a imprensa negra entre 1915 e 1923 se preocupava majoritariamente com pequenas notas, falecimentos, casamentos, festas religiosas, quermesses e mexericos, "apresentando de forma inexpressiva artigos reivindicatórios, apelos à conscientização, etc." ${ }^{\text {148 }}$, consideramos que o aspecto crítico de um jornal pode aparecer até na significação contida em seu título, em sua organização administrativa, na preocupação e no cuidado com os leitores, bem como na

\footnotetext{
${ }^{145}$ O Menelik, 17 out. 1915, n.1, p.3.

${ }^{146}$ O Menelik, 1 jan. 1916, p. 4.

${ }^{147}$ O Menelik, 1 jan. 1916, p. 1

${ }^{148}$ FERRARA, Miriam Nicolau. op. cit., p.45.
} 
missão a ser transmitida. O Menelik, assim como o rei etíope, trazia em si a capacidade de superação do negro sobre a elite dominante, o exemplo de integração a ser seguido. O jornal, mesmo de uma forma mais modesta, propunha a discussão dos temas que eram pertinentes à realidade do negro em São Paulo naquele momento.

Para além dos mexericos, dos concursos de beleza e das notas de casamento, havia o apelo à conscientização e à luta contra a discriminação e o preconceito raciais. O jornal foi publicado entre 1915 e 1916, portanto, em plena Primeira Guerra Mundial, evento sobre o qual não existe menção, não só pelo Menelik, mas por nenhum outro periódico negro até o final do conflito, em 1918.

Aparece, porém, em seu segundo exemplar, um conto a respeito da revolta dos negros na ilha de São Domingos. A história, fictícia ou não, relata que, durante a invasão de casas, um negro é preso após evitar a morte de uma jovem branca, pela qual era apaixonado. Morreu executado, preso a uma árvore, "e agora, junto ao cadáver, puderam dizer: que os negros são tão gente como os brancos" $" 149$.

Era assim, através de um episódio que dizia respeito especificamente "à classe", que se buscava a consciência étnica de uma população negra sofrida e excluída em meio à sociedade de brancos que era a capital paulista.

$* * *$

Em 1916 surgiam dois outros jornais de presença marcante e peculiar em São Paulo: $O$ Xauter e A Rua.

O Xauter apareceu em São Paulo no início de 1916. Conseguimos ver o exemplar n.2, datado de 16 de maio daquele ano. No cabeçalho constava a sua denominação como Jornal Independente e Propriedade de uma Sociedade Anonyma. Sua sede localizava-se à Rua Teixeira Leite n. 14, e não constava a periodicidade. A assinatura semestral custava $1 \$ 000$. Seus colaboradores se identificavam na maioria das vezes pelo primeiro nome ou pseudônimo (prática comum na época e entre os jornais negros), como Pindoba, Chefe e Victor Hugo. Regina Pahim descreveu ter sido esse jornal fundado por Deoclécio Miné.

149 O Menelik, 1 jan. 1916, op. Cit., p.2 
Em sua primeira página, os redatores dedicaram mais da metade do espaço a explicar o significado da palavra Xauter, tanto para seus leitores como em resposta a supostas provocações de outro jornal, A Rua:

\begin{abstract}
O que quer dizer Xauter?
Ora uma palavra que a primeira vista parece muito com qualquer cousa extrangeira, pode muito bem ser franceza ou allemã; mas assim sendo pode-se pronunciar de qualquer forma, porque ninguem tem obrigação de saber linguas extrangeiras.

[...]

Para gaudio de nossos leitores avidos de sabedoria ahi vae a resposta: Xauter significa, guia dos caminhantes nos areaes da Arabia deserta.

(Veja diccionario de Fonseca e Roquete pag. 967, columna segunda, linha 35.a).

Pois bem, levem o Xauter a beira da estrada do deserto, que elle cumprirá o seu dever. ${ }^{150}$
\end{abstract}

Em nossas pesquisas, encontramos o significado da palavra xauter derivado do árabe xater, que também quer dizer "homem perfeito", "homem perito, sabio, diligente na sua obrigação. "O Xauter he o piloto, que guia a gente nos caminhos e areas do dezerto da Arabia" ${ }^{151}$. Em suas primeiras páginas, e na forma incisiva como recomenda a seus leitores seguirem certos comportamentos adequados (como não frequentar bailes e associações de má fama, ou não atrasar pagamentos de mensalidades ao jornal), parece querer conduzir os leitores ao caminho da moral:

\footnotetext{
NO CRUZEIRO DO NORTE

Todas as mães de família e meninas que prezam a sua reputação, devem fugir da sociedade Cruzeiro do Norte, como se foge de um covil de tigres.

"O Xauter", ao entrar no salão, ficou horrorisado, de ver a immoralidade que alli impera.

O Cruzeiro do Norte é um antro de prostituição disfarçada!

Lá, fica a reputação de uma menina, e muitas vezes a honra de uma familia inteira.

Deveis leitores, fugir dessa sociedade, e nem pela rua passar quando estiverem ensaiando, porque esses ensaios vos encaminhará para a perdição. ${ }^{152}$
}

O discurso é tenso e os ataques são impiedosos aos clubes e associações que não se enquadram dentro de um determinado "padrão de comportamento". Essa, aliás, é uma temática que está sempre presente nos estatutos dos jornais, das associações e grêmios recreativos ligados à comunidade negra. Existem desentendimentos, disputas e

\footnotetext{
${ }^{150}$ O Xauter, 16 mai. 1916, n.2, p.1

${ }^{151}$ Ver SOUSA, João de. Vestigios da lingoa arabica em Portugal - Lexicon etymologico das palavras, e nomes portuguezes, que tem origem arabica. Academia Real das Sciencias de Lisboa (Typografia). Lisboa, 1830. Original da Harvard University. Digitalizado em 17 dez. 2007. Disponível em < http://books.google.com.br/books?id=iRMTAAAAYAAJ\&printsec=titlepage>Acesso 13 jun. 2009.

${ }^{152}$ O Xauter, 16 mai. 1916, p.2
} 
enfrentamentos entre alguns jornais, que vão desde problemas com comportamentos inadequados nos clubes até erros gramaticais encontrados em artigos e editoriais.

No segundo número de $O$ Xauter são encontradas, na primeira página, críticas diretas a um pequeno jornal da Barra Funda, O Binóculo, e a Deocleciano Nascimento, de O Menelik, cuja redação era "um antro (...), onde o idiotismo anda de braço dado com a ignorância". Mas o maior revide é direcionado ao pessoal de A Rua:

\begin{abstract}
Os redactores d" “A Rua”, tendo o cérebro fecalizado, recorreram as propriedades do ventre, para serem originaes entre os seus companheiros.

Depois de considerações fora de proposito, explicam (sem lhe termos perguntado) de onde vem o nome, "O Xauter".

Impotentes para desfazerem-se das nossas acusações e baseando-se num erro que encontraram a custo de muito rever a grammatica e o diccionario, vem dizendo que não estão incluindo na lista de Leonardo da Vinci.

$[\ldots]$

Esses homens que fazem tanta propaganda do seu saber ao que parece não fazem uso delle, pois ao pretenderem pregarem moral a um nosso companheiro, iniciam o tratamento da segunda pessoa do plural, e terminam na segunda do singular! Nas Notas e Noticias, na $2^{\mathrm{a}}$. Columan, $5^{\mathrm{a}}$. Linha, encontramos um erro que um menino de escola não commetteria. Na $2^{\mathrm{a}}$. Pagina, $1^{\mathrm{a}}$. Colummna, linha $13^{\mathrm{a}}$. Encontramos um outro. Se continuassemos na analyse, encontrariamos uma bôa porção delles. Não o fazemos para que os snrs. d' "A Rua" saibam que sahimos da escola para fazer o jornal e não o fazemos de escola. ${ }^{153}$
\end{abstract}

Em duas seções da primeira página, denominadas "A mensagem" e "Notas Políticas", O Xauter noticiava o fim de mandato de Rodrigues Alves e a posse de Altino Arantes como novo Presidente do Estado de São Paulo, de forma bastante positiva:

\footnotetext{
A MENSAGEM

No dia primeiro de Maio, o snr. dr. Rodrigues Alves, apresentou ao dr. Altino Arantes, o resumo dos seus trabalhos durante o quatriennio que se findou.

É um documento simples mas importante, não só pelo modo claro e positivo com que está exposto á atitude do governo deantes dos factos extraordinarios e imprevisto, como tambem pelos sabios conselhos que preocuparam o espirito publico.

(...)

NOTAS POLITICAS

$\mathrm{O}$ dr. Altino Arantes no dia $1^{\circ}$. De Maio, tomou perante o Congresso e o povo o dever de dirigir o destino do estado.

S. Exa., com o seu tino politico, promette desempenhar essa missão a contento de todos.

Os seus secretarios, são todos homens de valor jà demonstrado.

Emfim, a inteligencia, a grandeza e a bôa vontade o snr. dr. Presidente, soube reunir na forma de seus secretarios. ${ }^{154}$
}

\footnotetext{
${ }^{153}$ O Xauter, 16 mai. 1916, n. 2, p.1

${ }^{154}$ Idem, ibidem
} 
A redação informava logo no início da segunda página que as pessoas que não pagassem a assinatura até o dia 6 do mês seguinte teriam a remessa do jornal suspensa. A grande maioria dos jornais trazia essa mensagem, pois a contribuição dos assinantes é fundamental para a continuidade das publicações, ao lado das receitas com os anúncios.

Como foi dito, o jornal A Rua - literario, critico e humorístico - , criticado pelo Xauter, surgiu em 1916, fundado por Domingos José Fernandes, redator-chefe, e Oliveira Paula, redator-secretário, no início de 1916. Sua sede ficava no Brás, no Largo da Concórdia $\mathrm{n}^{\mathrm{o}}$ 4. A periodicidade era semanal, às quintas-feiras. Uma assinatura anual custava 10\$000; a semestral, 6\$000; números avulsos eram vendidos por $\$ 100$; números atrasados, por $\$ 200$, e sobre seções "livre-linha" eram cobrados $\$ 300$. Anúncios poderiam ser feitos a "preços módicos".

O exemplar analisado possuía quatro páginas e a primeira, trazia apenas sonetos e poesias. Na última página eram informados os pontos onde se poderiam encontrar exemplares:

"A RUA" é encontrada á venda todas as quintas-feiras nos seguintes pontos: Rua 15 de Novembro n.2 - Avenida Rangel Pestana n. 257 - Avenida Celso Garcia n. 115A - rua Belem n. 128 - Rua João Teodoro 258..$^{155}$

A segunda página trazia a "Secção Crítica", que se estendia até metade da terceira tecendo comentários sobre membros de bairros de São Paulo, como Centro, Brás, Belenzinho, Mooca, Luz e Canindé. Falava-se principalmente sobre a postura nos bailes e nas ruas, e a maioria das reprimendas apontava para os excessos com a bebida:

Avacalhamos...

O Aristides Cordeiro da Villa Thaide por ter tomado um formidável porre no anniversario do snr. Assis da rua Cajurú, chegando aponto de derrubar o prato da meza do Jantar e gatinhar por cima, dizendo que só tinha começado a beber. Ora seu Aristides, se isso foi o começo não sei como será o fim! $!^{156}$

O repórter ou correspondente de A Rua deveria estar sempre atento ao que acontecia na cidade envolvendo principalmente integrantes da comunidade negra:

Embirramos...

\footnotetext{
${ }^{155}$ A Rua, 24 fev. 1916, p.1

${ }^{156}$ Idem, ibidem, pp.2-3
} 
Com o palhetinha que no Largo da Concordia tentava seduzir para outra fábrica um bando de moças dizendo que ellas poderiam ganhar $5 \$ 000$ por dia. Olha seu zebra, se os Ingleses souberem te mandarao prender. ${ }^{157}$

Ainda na terceira página, havia o anúncio de um concurso de beleza, em que participavam até aquele momento noventa e seis senhoritas:

\section{CONCURSO DE BELLEZA}

"A RUA", que é um apreciador fanatico do bello, inicia hoje um concurso de belleza que será encerrado no número 16. Será offerecido, a formosa senhorita que entre as outras (ilegível) considerada rainha, 1 libra esterlina; a segunda em votos 1 caixa de papel de cartas a phantasia e a terceira uma assignatura annual da "A RUA".

As Urnas e com coragem, ó mocidade vibrante!... ${ }^{158}$

A última página era reservada a anúncios publicitários, num total de cinco. Os anunciantes eram o Instituto Musical, Mathilde Dias da Cunha (“ A Belleza da Mulher”), o Cinema de Gogliano \& Cruz, o Teatro Isis dos Irmãos Taddeo e a Tinturaria Luzitania de Antonio Augusto Alves. Somente os dois primeiros apresentavam o endereço. Havia ainda uma seção denominada "Indicações Úteis", onde se anunciavam os serviços de médicos, "parteiras diplomadas", advogados e salões de barbeiros e cabeleireiros. A grande maioria estava localizada à Avenida Celso Garcia, Avenida Rangel Pestana, Rua 15 de Novembro e Rua Bresser, que por sinal eram as localidades de atuação dos repórteres de $A$ Rua.

Com isso, e para além dos encontros, fofocas e eventos nos bailes, o jornal prestava um serviço de utilidade pública para a população negra, como indica o anúncio sobre o Cartório de Paz da Mooca:

\section{DISTRICTO DE PAZ DA MOÓCA}

Os casamentos e registros de obito e nascimentos deverão ser feitos no respectivo cartorio á Rua da Concordia 17, divisa do districto.

O rio Tamanduatehy, divide a Moóca da Liberdade e Cambucy, as avenidas Rangel

Pestana e Celso Garcia dividem a Moóca do Braz, e, Rua Bresser a divide do

Belenzinho em toda sua extensão até Villa Prudente. ${ }^{159}$

$$
* * *
$$

Em 1918, surgia O Alfinete, criado para "cutucar", "alfinetar" as pessoas e fazer críticas a seu comportamento. Orgam Litterario, critico e recreativo dedicado aos homens de cor, tinha como diretor Augusto de Oliveira e Frederico Baptista de Souza era o secretário.

\footnotetext{
${ }^{157}$ Idem, ibidem.

${ }^{158}$ Idem, ibidem, p. 3

${ }^{159}$ Idem, ibidem, p.4
} 
Foi publicado quinzenalmente entre 1918 e 1919, e mensalmente em 1921. A assinatura anual custava $4 \$ 000$, a semestral, $3 \$ 000$ e os exemplares avulsos, \$100. Até 1921, as colaborações deveriam ser enviadas à sede do jornal, inicialmente à Rua Tibiriçá n. 6, e depois, à Rua Rodrigo de Barros n. 53.

Em geral, o jornal era publicado em quatro páginas, havendo um editorial anunciado pela seção "aos nossos leitores" e que poderia ou não ser assinado pelo diretor Oliveira. Em seguida, algum artigo escrito por um colaborador ou leitor.

A segunda página normalmente trazia a continuação do artigo e uma seção chamada "Notas Diversas", onde eram comentados os eventos nos centros recreativos, notas de casamentos e batizados.

A penúltima página trazia um mural denominado "Phrases Apanhadas", em que tanto pessoas da redação como leitores identificados por pseudônimos mandavam seus recados, na maioria das vezes em tom de crítica ao comportamento alheio. Eram comentados desde a poeira na roupa do frequentador do clube até a falta de pagamento na praça:

Adelia: Elle está me procurando. (Angú)

Durante o tempo que eu for thesoreira do [Grêmio Recreativo Flor da] Independência, elle não entra aqui (Cameda) ${ }^{160}$

Magadalena com os vestidos muito curtos (ECONOMIA) ${ }^{161}$

Na terceira página costumava-se publicar as colunas "De sociedade em sociedade" ou "Pelos Salões", que falavam especificamente das associações, centros e grêmios recreativos. Os mais comentados eram Elite, Smart, 13 de Maio, 28 de Setembro, Pendão Brazileiro e Kosmos.

No entanto, muito além dos mexericos, das regras de comportamento, das fofocas e da preocupação em "alfinetar negrinhos e negrinhas" por ocasião dos bailes, $O$ Alfinete carregava em seus editoriais mensagens incisivas e direcionadas não só à população negra, mas às elites, sobre as oportunidades de mobilidade social e o acesso ao emprego no pós-abolição em São Paulo;

(...) Mas de que serviu finalmente a lei do abolicionismo no Brazil?

${ }^{160}$ O Alfinete, 3 set. 1918, p.3

${ }^{161}$ Idem, 28 ago. 1921, p.3 
Unicamente para mostrar ao extrangeiro a nossa apparente civilização, porque se ella aboliu a escravatura official, implantou o servilismo particular; se derrubou o regimen de escravas obrigatorios impoz o de servos voluntarios.

Quem são os culpados dessa negra mancha que machuca eternamente a nossa fronte?

Nós, unicamente nos que vivemos na mais vergonhosa ignorancia no mais profundo absecamento moral, que não comprehendemos finalmente a angustiosa situação em que vivemos. $^{162}$

A descontinuidade das edições era notória, com espaços longos entre publicações, algumas vezes por problemas financeiros, em outras vezes por força maior, como à época da gripe espanhola em São Paulo:

O $5^{\circ}$ numero do nosso jornal sahe com um sensível atraso, justificando-o sobejamente a situação em que nos collocou a "epidemia" reinante, que a nós todos alcançou. Assim sendo, pensamos que estamos desculpados pelos que cheios de anciedade, nos esperavam impacientes. ${ }^{163}$

O número de anúncios era pequeno, e o espaço disponível para quem se interessasse em divulgar propaganda era claramente delimitado. No exemplar de 3 de setembro de 1918, há somente quatro anunciantes, sendo três deles localizados à Rua da Liberdade: A Tinturaria Chimica e Alfaiataria Sportsman, de José Espanholete, a Papelaria São Joaquim, de Ricardo Knorich e o Escriptorio de Advocacia do Dr. João Francisco da Cruz.

No ano de fundação do jornal, a Primeira Grande Guerra Mundial está perto do fim. Essa fase marca o surgimento de editoriais mais consistentes, dando maior ênfase à exaltação do negro, aos bons exemplos, à valorização do trabalho e da instrução como únicos meios para conseguir a tão sonhada integração na sociedade dos brancos. Por outro lado, ainda se refere ao pensamento eugenista que vigorava à época:

Nas leis psicológicas das evoluções dos povos, o papel da raça negra, embora seja inferior em alguns paizes como nos da Affrica, é tão importante e marcha em igualdade de condições moral e intellectual quanto as outras raças. ${ }^{164}$

O Alfinete compara a capacidade criadora e a inteligência do norte-americano com a situação do negro no Brasil, a fim de levá-lo a acreditar que a única saída contra a apatia e o desalento é a instrução:

Nos Estados Unidos a sua capacidade creadora é assombrosa. Ella [população negra] distingue-se em todos os pontos de vista na agricultura, e na industria, o despertar de sua energia vital, aliada a uma sólida cultura intellectual desenvolveu

\footnotetext{
${ }^{162} O$ Alfinete, 3 set. 1918 , p.1

163 O Alfinete, 4 jan. 1919, p.3

${ }^{164}$ O Alfinete, 3 set. 1918, n.2, p.1
} 
maravilhosamente o progresso dessa grande nação, cujo commercio supplantou os das maiores potencias da Europa.

(...)

Cultivemos, extirpemos o nosso analphabetismo e veremos se podemos ou não imitar os nort-americanos. ${ }^{165}$

A crítica ao mau comportamento e os exemplos sugeridos de postura podem ser vistos como uma forma de exercer um certo controle social sobre o negro. Em suas mensagens, o jornal parecia criticar abertamente a tendência do negro em imitar os costumes do branco em São Paulo:

\section{PRECONCEITOS DE RAÇA}

O que nós amamos e veneramos nos nossos semelhantes não é sua forma corporea, nem tão pouco temos a ideia das suas virtudes pelo seu vestuário e calçado, assim também não devemos olvidar ou desprezar o homem de cor preta, porque muitos dessa raça poderiam ser o estímulo na prática do Bem e do Dever, e muitos brancos ou a esses moços bonitos que são verdadeiros parasitas sociaes, cérebros ôcos sem ideaes, não tendo um fim nobre e elevado a attingir na vida. ${ }^{166}$

A educação e a formação profissional também são formas de exaltação da raça negra, caminhos para a mobilidade social e a consequente aceitação na cidade do trabalho. No entanto, o discurso é pragmático, dentro da realidade ocupacional que era oferecida ao negro em São Paulo:

\section{OS PRETOS E O PROGRESSO}

É preciso que os pretos tenham a aspiração de querer ser alguma cousa no futuro; para isso é preciso que todos tenham força de vontade, ensinando aos vossos filhos o que nossos paes não puderam aprender.

Avante! Meus irmão de cor, caminhae com o progresso da nossa capital, mandae vossas filhas para aprenderem costura, bordados e engomados; vossos filhos, depois que sahirem do Grupo Escolar, mandae-os aprender officio de sapateiro, funileiro, mechanico encadernador e typographo etc.

Só assim é que todos os nossos irmãos de cor, deixarão de ser cosinheiros, copeiros e arrumadores de quartos. ${ }^{167}$

O texto acima é parte do artigo assinado pelo colaborador José Benedicto Martins, que em outra passagem faz uma comparação com o imigrante, utilizando-o como modelo a ser seguido e criticando a falta de ambição de parte da população negra:

É preciso que todos os homens de côr, emitem os bellessimos exemplos das colonias estrangeiras, procurando mandar ensinar uma profissão para seus filhos ganharem a vida no futuro.

\footnotetext{
165 Idem, ibidem.

${ }^{166}$ Idem, ibidem.

${ }^{167}$ Idem, ibidem, p. 2
} 
Vedes os estrangeiros que aqui desembarcam para trabalharem como colonos em fazendas, e, hoje já abandonando estas, a sua maior parte está trabalhando pelo seu officio, na capital e mesmo no interior.

(...) Nada sabemos porque não queremos aprender um officio para ganhar honradamente nossa vida.

Ficamos contente sómente por obter uma modesta collocação de servente, de uma repartição publica, ou de um escriptorio. Assim como esse ordenado basta que, o passamos comprar um terno para envergarmo-nos aos domingos, de noite, e não procuramos mais nada! ${ }^{168}$

Outro tema recorrente era o combate ao alcoolismo, preocupação presente na maioria dos jornais, como poderemos ver mais adiante:

Li ha dias num jornal de Sorocaba que uma sociedade recreativa d'aquella cidade deliberou, em reunião, abolir o uso de bebidas alcoolicas por occasião de suas festas, permitindo tão somente o uso das bebidas sem alcool, como sejam: Nectar, Sis, gazosas e etc.

Abolindo o álcool das nossas sociedades, e mesmo das mezas dos nossos lares, muito conseguiremos em favor da nossa classe de cor" ${ }^{\text {,169 }}$.

Podemos notar que por se tratar de um dos primeiros jornais negros na Capital, $O$ Alfinete conseguir se sobressair não só como um jornal de mexericos e eventos, mas também pela qualidade de seus editoriais, os quais já demonstravam alguma maturidade em relação ao cotidiano do negro em São Paulo e suas possibilidades de ascensão.

$* * *$

Também em 1918 surge $O$ Bandeirante, vinculado ao Grêmio Recreativo, Beneficente, Dramático e Literário Bandeirantes. Foi fundado por Antonio dos Santos, que se tornou seu diretor, e pelo militar do Exército Joaquim Cambará, presidente também do Grêmio Recreativo Kosmos. O jornal possuía um diretor literário, J. D’Alencastro. Seu subtítulo inicial era orgam mensal de defeza da classe dos homens de cor, passando algum tempo depois a orgam de combate em prol do reerguimento geral da classe dos homens de cor.

Esse periódico existia em função do Grêmio Bandeirantes, uma vez que reproduzia em suas páginas o cotidiano de bailes, ensaios e outras convivências:

(...) e referir-se áquelle, ao nosso Gremio, é também referir-se a este, ao nosso jornal. Ambos, formam um todo, uma única peça.

${ }^{168}$ Idem, ibidem.

${ }^{169}$ O Alfinete, 28 ago. 1921, p. 4 
(...) o Gremio Bandeirantes e este jornal são já, para todos nós, não somente uma causa collectiva, em a qual todos tomam uma minima parte, mas, sim,, uma causa propria.

(...) Tanto isto prova, que o seu reapparecimento hoje é em comemoração do anniversario do 'Bandeirantes'. ${ }^{170}$

Por isso, era mais encorpado que os demais, pois além de tais notícias, também trazia uma seção onde se cobravam os devedores e até mesmo comentários de matérias da grande imprensa.

O Bandeirante foi inaugurado em 6 de abril de 1918, mas o segundo número do jornal somente apareceu quatro meses depois, fruto da dissidência de vários associados, como denuncia o editorial:

\footnotetext{
VENCENDO A ENCOSTA

(...) Muitos dos que comnosco deram o passo inicial - que foi o impulso maximo para a fundação, não só de nosso Gremio como também de nosso jornal, - ficaram para atraz, abandonaram-nos em meio da jornada, sem nenhuma justificativa plausivel.

[...]

Não precisamos de timoratos e tampouco de desalentados.

[...]

E o nosso jornal, apezar do abandono de alguns, verdadeiros desertores, ahi está mais disposto do que nunca para desenvolver a campanha a que se obrigou em seu programma de estréa. ${ }^{171}$
}

Poder-se-ía associar o nome do jornal à fase de crescimento e pujança por que passava a cidade de São Paulo, como a consolidação dos sistema bancário e obras de saneamento, e onde se vislumbravam oportunidades para o negro, a partir do momento em que este pudesse extirpar do meio em que vivia o analfabetismo, o vício e a prostituição. Buscava-se, pelo que se compreende do segundo sub-título, uma elevação de valores.

Ainda na primeira página da edição de agosto, noticiava a despedida de Joaquim Cambará das atividades ligadas ao jornal e ao Gremio Kosmos e sua mudança para Caçapava. Ele era conhecido pelo estilo agregador e sua ausência foi lembrada em inúmeras manifestações nos clubes e associações paulistanos:

No dia 4 corrente, seguiu para Caçapava, neste Estado, onde foi se incorporar ao $6^{\circ}$ Regime de Infantaria, o nosso distincto amigo Joaquim Cambará.

Dignissimo Presidente do Gremio Dramatico e Recreativo "Kosmos" a sua forçada ausencia torna-se doloroso ao corpo social, que o considera a sua alma mater, o seu esteio, o seu equilibrio, e a quem tambem devem as associações de homens de côr a

\footnotetext{
${ }^{170}$ O Bandeirante, agosto de 1918, n. 2, p.1

${ }^{171}$ Idem, ibidem.
} 
verdadeira fraternidade que hoje gozam, no campo social, onde ha pouco medravam as dissenções.

(...) No Centro "Smart", usaram da palavra o seu Presidente Gastão da Silva e o $2^{\circ}$ Secretario; no Gremio de Damas "Elite Flor da Liberdade", foi saudado pela gentil senhorita...e pelo Secretario Honorario; no Pendão Brasileiro, falou o Presidente dessa agremiação; na "Flôr da Independencia" falou em nome da Sociedade o Senhor Benedicto dos Santos; e nos "Bandeirantes", o senhor José Diniz da Silva, $1^{\circ}$ secretario. Todas essas sociedades, pelos seus oradores, demonstraram sentimentos pela retirada do grande amigo $(\ldots)^{172}$

Cambará ainda assinava um artigo sobre um recém-empossado parlamentar de Sergipe e a forma preconceituosa pela qual a questão foi tratada por um correspondente de jornal da imprensa tradicional:

\section{DEPUTADO DE COR}

O "Diario Popular", de 9 de Abril, publicou um comunicado do seu correspondente no Rio de Janeiro, no qual dizia que breve tomaria assento no Congresso Nacional, um deputado de côr preta, eleito pelo Estado de Sergipe.

Esta comunicação feita em tom ironico, teve por fim menosprezar o deputado eleito, desprestigiar o glorioso Estado que o elegeu e abater moralmente a classe dos homens de côr.

(...) Quanto á sua cor, em que o impede ser eleito?

Não está elle no gozo dos seus direitos civis e politicos?

Não está elle amparado pela nossa Constituição? Qual foi então o motivo que causou surpresa ao sr. Correspondente?

Foi o eterno desrespeito às nossas Leis, e o vil e inconcebivel preconceito de raça, que infelizmente existe em nosso Paiz. ${ }^{173}$

$O$ Bandeirante, assim como a maioria dos jornais dessa imprensa, prestava homenagens praticamente míticas, assim definidas por Roger Bastide, aos grandes abolicionistas, como José do Patrocínio e Luiz Gama.

Alguns meses depois de noticiar a retirada de Joaquim Cambará, a edição comemorativa de um ano do jornal voltava a prestar-lhe homenagens, mas agora por seu falecimento:

\footnotetext{
"redator, fundador e alma mater d' "O Bandeirante", [foi] quem procurou harmonizar as sociedades; a ele coube a honrar de inaugurar o $1^{\circ} \mathrm{n}$. do "Bandeirante"; quem falava nessa ocasião era Cambará, e quem era Cambará? Um militar, um defensor da Pátria, um homem cheio de valor e honestidade. Ao terminar as suas palavras, levantava a bandeira Nacional, que então cobria o $1^{\circ} \mathrm{n}$. do jornal, e ao levantá-la, pareceu-nos que entusiasmado, ganhava uma batalha, e assim era; inaugurar um jornal, ter um baluarte para a defesa dos fracos, digno de entusiasmo..." (Artigo de Frederico Baptista de Souza, colaborador e secretário de $O$ Alfinete) $)^{174}$
}

\footnotetext{
${ }^{172}$ O Bandeirante, agosto de 1918, n.2, pp.1-2

${ }^{173}$ Idem, ibidem, p. 2

${ }^{174} O$ Bandeirante, abril de 1919, n.4, p.1
} 
Um fato curioso provocou grande repercussão junto à comunidade negra e aos leitores de $O$ Bandeirante. Segundo reportagem do jornal $O$ Estado de São Paulo, alguns rapazes negros foram detidos por secretas da Polícia durante o enterro de um negro pobre. Essa notícia traz à tona algumas representações sobre o estado policialesco vivido por negros e outros marginalizados na cidade:

\section{OS AGENTES DA POLÍCIA EM AÇÃO}

Os homens de cor preta nesta terra sempre foram as vitimas dos secretas e agentes de Polícia. Dezenas de barbaridades estes mantenedores da ordem pública têm cometido, prendendo, esmurrando os pobres homens de cor, que às vezes não têm uma pessoa que lhes possa acudir ou mesmo lavrar um protesto contra esses individuos, barbárie.

O Jornal "O Estado de São Paulo", na seção de queixas e reclamações, do dia 17 de agosto próximo passado, publica o seguinte:

Em 15 do corrente subiu da rua Major Diogo o enterro, a mão, de um pobre preto que,tendo morrido paupérrimo, não podia seguir para a última morada em cocho de luxo. Levaram-no ao cemitério do Araçá, em sentimento de piedade, alguns colegas e amigos. Na volta apareceram de súbito aos condutores do morto quatro indivíduos que, sem motivo algum e alegando a sua qualidade de secretas, lhes deram voz de prisão, só porque se tratava de gente de cor, pobre, vezada aos trabalho das officinas e sem relações nenhumas com a polícia. Houve protestos das partes dos sitiados, mas os que mais protestavam, em número de quatro, foram presos.

Diz-nos em conclusão, a pessoa que nos escreve, relatando o facto:

É um abuso, senhor redactor, que precisa ter um fim, e immediatamente. Já um pobre não pode morrer porque quem o for carregar à ultima morada ficará preso, naturalmente porque fez um acto de caridade, foi dar o último adeus ao seu amigo e colega.

É uma necessidade, com effeito, que o sr. Dr. Delegado geral ponha termo a semelhante estado de coisas.

Os agentes de polícia estão exorbitando dos poderes que lhes foram conferidos.

As prisões succedem-se, sem motivo algum e os que são innocentes nem sempre podem manter a calma necessária ante o vexame a que os submetem.

Os tempos ignominiosos de effectuar prisões por palpite já vão longe.

É preciso deslembrá-los, para honra nossa, não ressuscitá-los como aí estão fazendo, nivelando a nossa terra a qualquer domínio de botocudos. ${ }^{175}$

Quem assina o artigo é Gastão Rodrigues da Silva, fiscal municipal e presidente eleito e reeleito do Centro Recreativo Smart. Foi diretor do jornal Quilombo e do Grêmio Recreativo Kosmos, além de um dos fundadores do Club Recreativo São Paulo, do Club Athlético Paraiso. Também fundou o jornal Liberdade, onde exerceu o cargo de redator.

Em outra coluna do jornal, assinada por J. D'Alencastro, o protesto contra a prisão dos rapazes negros continua:

\section{EM FERRO FRIO}

Pelas columnas d'este jornal deve sahir hoje a publicação de um brado de alarme que é um justo protesto contra uma injustiça praticada contra homens simples e

${ }^{175}$ Idem, ibdem, p.2 
trabalhadores, contra homens de côr. Esse brado da mais justa revolta parte do sr. Gastão R. Da Silva, em um arquivo que elle hoje subscreve.

(...).

Diante da dispersão em que vivem os homens de côr - que nada fazem por se protegerem mutuamente no meio cosmopolita em que vivem, que não se harmonisam, que não se associam n'uma causa que lhes assegure a relativa tranquilidade contra todas as eventualidades na vida, que lhes forneça os meios contra tudo o que lhes venho conspurcar os seus legítimos direitos de cidadãos livres, de cidadão brasileiros, factos como o que o Sr. Gastão commenta são muito naturaes.

(...)

Quando se fundou o Gremio dos Bandeirantes, foi lido em sua festa inaugural o seu vasto programma, o mesmo que serviu de plataforma para o apparecimento deste jornal; dentre as muitas ideias alli apontadas e para a realisação das quaes se pedia o concurso de todos, fossem ou não associados do BANDEIRANTE, está aventada a da creação de um fundo especial para soccorrer aquelles que estivessem enfermos e necessitados e aquelles que fossem encarcerados injustamente.

Pois bem. Ninguem ouviu e nem leu essas nossas sensatas palavras.

Agora o Snr. Gastão vem apontarnos o facto amargo de que foram encarcerados quatro pretos sem motivo justo, só porque voltavam do cemiterio - onde deixaram o corpo frio de um irmão que morreu á mingua!...

E nós perguntamos:

Porque morreu aquella creatura á mingua?

(...)

E aquelles pretos generosos, já foram postos em liberdade? Já se acham no seio de suas respectivas familias inquietas?

Não o sabemos. Tudo ignoramos.

Não estarão elles, aquelles coitados, aquelles infelizes desprotegidos, trabalhando a morrer lá pelos sombrios sertões do Nordeste, como deportados?

Ah! Esta duvida amargosa que nutrimos agora não tinha razão de subsistir si a nossa voz tivesse sido acatada; ahi estaria um fundo para ajustar advogado - que iria em soccorro dos infortunados presos.

(...)

Ninguem nos ouviu e ninguem nos ouvirá...Si se tratase de angariar recursos para bailes diarios, então não faltariam applausos e addhesões..Mas, como se trata de um fundo para a defeza e soccorro, ninguem da um passo a frente...Porque não abraçar o programma do "BANDEIRANTES"?

Que tristeza!..Sempre desunidos! Sempre desprotegidos! Sempre perseguidos e sem um braço generoso que os defenda!...

(...)

É amargo, é dolor so tudo isso!...Mas, que fazer? Si nos parece que é a força de um Destino adverso que impulsiona essa marcha factal de desaggregação!

Pavoroso deserto que não repercute a nossa voz, choramos sobre os damnos que causaes! ${ }^{176}$

Ve-se claramente o sentido de desunião causador de inquietação junto às lideranças dos jornais, a apatia combatida desde os editoriais de $O$ Alfinete, e a necessidade de mobilização dos membros do Grêmio e das associações, deixando de lado o interesse festivo e participando mais da vida em comunidade, auxiliando os mais necessitados, inclusive de assistência jurídica.

${ }^{176}$ Idem, ibdem 
Nas colunas sobre eventos sociais em clubes, é elogiada a presença de número significativo de damas e cavalheiros nos ensaios e a presença dos diretores de outras associações, entre elas o Centro Recreativo Smart, o Grêmio Kosmos, os clubes Elite Flor da Liberdade e Chuveiro de Prata. Um brinde proposto por Gastão Rodrigues tinha grande valor simbólico, uma vez que os clubes tentavam controlar os excessos com bebida alcóolica e outros comportamentos inadequados na realização dos bailes;

\begin{abstract}
Apesar da ingratidão porque passamos, levado a effeito pela malograda desunião, mal que infelizmente transita entre nos, mesmo assim o nosso Gremio tem progredido continuadamente. Os ensaios dansantes têm sido sempre animados; por exemplo o de 18 do mez findo, esse esteve concorridissimo, pois contamos 58 damas e 55 cavalheiros.

(...) Nesse ensaio a nossa directoria foi alvo de grande manifestação de apreço por parte da directoria do Smart; O seu presidente o sr. Gastão Rodrigues da Silva, offereceu-nos um copo dagua e levantando nessa occasião expansivo brinde, dizendo que com o coração a transbordar de alegria congratulava com os consocios do "Gremio Bandeirantes" pela concorrencia do ensaio que se realisava (...) ${ }^{177}$
\end{abstract}

O desalento, o vício, a vagabundagem e a prostituição eram fatores que impediam a integração à sociedade dominante e por isso, duramente atacados pelos editoriais da imprensa negra em geral. Na opinião dos redatores, existiam possibilidades de ascensão, cabendo aos negros conduzirem seu destino através da perseverança e do combate ao desânimo :

(...) Devemos queixar de nós mesmos, de nossa propria negligencia, de nossa falta de comunhão de vistas. Vivendo, como vivemos, em um meio cosmopolita como este.

(...) Jamais conseguiremos a amplitude das considerações que almejamos. A culpa não é dos brancos, é nossa! Pois os meios estão ahi ao nosso alcance e disposição. ${ }^{178}$

Para manter-se, o jornal era bastante rigoroso com o pagamento de mensalidade por parte de seus assinantes. A assinatura anual custava $3 \$ 000$, e a semestral, $2 \$ 000$, com pagamento adiantado. Porém, tão grande quanto a lista de devedores, eram os problemas que o Grêmio e o jornal atravessavam, algo comum em se tratando da imprensa negra, já que na maioria das vezes os redatores e diretores tinham de socorrer as edições para a publicação dos exemplares:

OS HEROES DA INCAPACIDADE...

Por falta de retirarem os recibos de suas mensalidades vencidas e devidas ao Gremio BANDEIRANTES, e, portanto, por deixarem de solver os seus compromissos para com esta associação, o foram em sessão realisada em o proximo mez passado pela

\footnotetext{
${ }^{177}$ O Bandeirante, abril de 1919 , n. 4, p.3

${ }^{178}$ O Bandeirante, setembro de 1919, n. 3, p.1.
} 
competente Directoria, postos fòra do quadro de associados a bem do progresso do Gremio.

São estes os taes: Nestor E. Ferreira, Ernesto E. Balthazar, João de Alencar (o sempre sumido) e Carlos Costa.

[..]

Nota da Redação

Com elementos d'essa natureza nenhuma associação pode vingar: o que pode acontecer é como o andar caranguejo: - sempre para atraz...

Portanto é andar bem avisado, em seleccionar o quadro de associados de cada associação, deixando, apenas, aquelles que sabem cumprir com os seus deveres.

“Quem não pode não inventa moda" Isso é do adagio antigo, mas é verdadeiro. ${ }^{179}$

A nota acima encontra-se em uma coluna permanente chamada "Notícias Diversas", que informa além desse tipo de ocorrência, aniversários, batizados, falecimentos e outros assuntos. Entre tais notas, identificamos a que tratava da formatura de Deocleciano Nascimento, fundador de $O$ Menelik, anteriormente citado:

\section{FORMATURA}

Formou-se em Comercio, pelo Lyceu Salesianos, desta capital, recebendo o grau de guarda-livros, o snr. Deocleciano Nascimento, redactor do saudoso "O Menelik". Na collação de grau que teve lugar em Janeiro, no theatro do referido collegio, elle demonstrou, perante selecta assistencia, o valor de seu caracter sentimentalista num improvisado e bem expressivo discurso. Não lhe faltaram palavras em applausos ao seu talento. ${ }^{180}$

Além dessa, o jornal apresentava a coluna "Pelas Associações", onde comentava os principais acontecimentos nos grêmios e clubes dançantes desde a última edição, com foco no aparecimento e no aniversário das entidades e nos assuntos abordados pelas assembléias. Ao final, relacionava as pessoas autorizadas a "angariar assinaturas" para $O$ Bandeirante, fornecendo nome completo e endereço dos mesmos. Estavam encarregados representantes não só do periódico ou de seu Grêmio, mas pessoas de outras associações, como Kosmos, Smart e Elite Flor da Liberdade.

É possível que os problemas financeiros enfrentados pelo jornal durante sua curta existência estivessem relacionados ao reduzido números de anunciantes. Verificamos que a edição de abril de 1918 trazia apenas a Typographia Gianotti, localizado no canto inferior esquerdo da terceira página. Na publicação de abril de 1919 já havia um pequeno espaço na quarta página dedicado aos anúncios, onde estavam presentes a Casa Cabral, situada à Rua de São Bento n. 33B, a Farmácia O Globo de Euclydes Carvalho, na Rua Barão de Itapetininga 43 e a própria Typographia Gianotti, localizada à Rua Formosa n. 8.

\footnotetext{
${ }^{179}$ Idem, ibidem

${ }^{180}$ Idem, ibidem, p.3
} 
Em 14 de julho de 1919 é fundado o jornal A Liberdade, com o subtítulo Orgam dedicado á classe de côr, critico, literario e noticioso. Sob a direção de Gastão Rodrigues da Silva, secretariado por Frederico Baptista de Souza e gerenciado por Joaquim Domingues, cobrava $5 \$ 000$ réis por assinatura anual, $3 \$ 000$ por semestre, $\$ 100$ por exemplar vendido "no dia” e $\$ 200$ por exemplar atrasado. Em 1920, a assinatura anual passava a custar $6 \$ 000$, a semestral 4\$000 e o exemplar avulso \$200. O pagamento deveria ser feito adiantado e os exemplares podiam ser encontrados no engraxate da Rua 15 de Novembro n. 2, próximo ao Café Girondino.

A primeira sede localizava-se no Largo do Riachuelo n. 56, onde também funcionava o Salão Internacional, de Pedro Chirico. O local era alugado para ensaios, bailes, reuniões, batizados e casamentos.

A partir de 9 de maio de 1920, o jornal se estabelece na Rua Vergueiro 94. Foi publicado quinzenalmente entre 14 de julho de 1919 e 31 de outubro de 1920, perecendo devido às frequentes dificuldades financeiras.

Frederico Baptista anuncia a criação do jornal, enaltecendo a figura de seu fundador:

Devido á iniciativa do sr. Gastão Rodrigues da Silva, apparece hoje mais um jornal para tratar da defeza dos homens de côr, quando no direito dessa defeza.

Gastão da Silva, homem alegre, onde a tristeza não tem morada, apreciador da ordem, apregoando a moral social, possuindo fulgurante radiação de espírito...não vacilará para dizer a verdade, seja ella recta e penetrante, contando que sua desenvoltura dão-lhe forças para combater, e elogiar aos que se tornarem dignos de sua atenção ou desprezo.

(...)

"que A Liberdade consagre o seu surto de energia, a favor do levantamento moral da classe, no meio deste desalento em que vivemos, não desalentando dos ardorosos deveres de combate em prol da Patria - são os votos que apresentamos ao seu incançavel fundador",181

O formato do jornal era muito semelhante ao do Bandeirante, pois Gastão da Silva e Frederico Baptista eram colaboradores assíduos daquele periódico e de várias associações, como o Centro Smart, o Kosmos e o Elite.

${ }^{181}$ A Liberdade, 14 jul. 1919, p.1 
Na primeira página havia sempre a mensagem principal aos leitores, sob o título de um artigo específico ou com a coluna intitulada "Vagando", que se iniciava sempre com uma frase de efeito, anunciando o tema principal do editorial:

Quando a miseria bate á porta, a vergonha sahe pela janela. (9 de maio de 1920)

A justiça e a caridade são as grandes virtude sociais. (12 de setembro de 1920)

Quem se veste de ruim panno, veste-se duas vezes por anno. (31 de outubro de 1920)

A coluna "Vagando" era sempre assinada pelo "Matuto", pseudônimo usado por Gastão Silva.

O jornal ainda possuía as seções "Pelos Salões" ou "Pelas Sociedades", onde eram comentados os eventos sociais; a coluna "Criticas", que falava sobre o comportamento dos frequentadores de bailes e pontos de encontro; o espaço reservado para "Notícias", onde se noticiavam casamentos, batizados, aniversários e notas fúnebre, e a seção reservada para anúncios, na última página.

A exemplo do Bandeirantes, os membros da comunidade que não se comportavam adequadamente eram repreendidos e até excluídos do meio social:

\title{
DESAPPARECIMENTO
}

Desappareceu do meio social, por ter commetido diversas faltas de abuso de confiança, o sr. Carlos José do Nascimento. Ao darmos esta noticia muito lamentamos a falta de juizo e de não saber viver honradamente como os outros vivem, sem lesar a ninguem. ${ }^{182}$

Dos quatro exemplares analisados, apenas a edição número 1 trazia um poema em sua primeira página:

\author{
ALMA MORTA \\ I \\ Estava a Morte alli, em pè, deante. \\ Sim, deante de mim, como serpente. \\ Que dormisse na estrada, e de repente \\ Se erguesse sob os pés do caminhante \\ II \\ Era de ver a funebre bacchante! \\ Que torvo olhar! Que gesto de demente! \\ E eu disse-lhe: Que buscas, impudente \\ Loba faminta, pelo mundo errante? \\ - Não temas, respondeu (e uma ironia \\ Sinistramente extranha, atroz e calma,
}

\footnotetext{
${ }^{182}$ A Liberdade, 14 de julho de 1919, n. 1. p.3.
} 
Lhe torceu cruelmente a bocca fria).

IV

Eu não busco teu corpo...Era um trophéu

Glorioso de mais. Busco a tua alma

Respondi-lhe: A minha alma já morreu

(Eponina R. da Silva) ${ }^{183}$

A partir de maio de 1920 o subtítulo sofreu uma pequena modificação: a palavra "crítico" aparece antes e o termo "dedicado aos homens de côr" vai para o final da frase, que passar a ser orgam crítico, literário e noticioso, dedicado aos homens de côr. Nessa edição, o tom do discurso é mais incisivo, chamando a atenção do leitor para a especulação imobiliária, as condições de habitação e a crise econômica em São Paulo:

Dizem, e é verdade que os proprietarios de casas de aluguel tem especulado com as propriedades as miserias da classe desprotegida da fortuna; e a coisa não é só isso: augmentam o aluguel de $40 \$$ para $100 \$$, e assim sucessivamente, como sou testemunha de um acto deste, ouvindo o proprio prejudicado.

(...) demais a mais, proprietarios ha, como o da Villa Conde de Sarzedas, que diz ou quer banir dalli o elemento de côr. Ora, alguns annoz atraz, davam graças em alugar seus predios (porões) para as cosinheiras, porque não paravam em casa e havia muitas casas para alugar, hoje esquecem que esse elemento muito ajudou a pagar as dividas contrahidas para a edificação, porque o elemento mais elevadona sociedade ha bem pouco tempo não iria residir em villas e porões; hoje, porém, que as cousas estão bicudas, não é descredito, porque muita gente bôa sujeita-se a isso, pela necessidade e imposição dos gananciosos proprietarios, que não se condõem da miseria dos outros, comquanto o seu elevado aluguer seja pago $(. . .)^{184}$

O jornal chama a atenção para o preconceito racial ao falar de um salão “encrenqueiro", localizado à rua Glycerio:

A nossa raça precisa comprehender que os bailes alli foram suspensos por sua causa: lembrem-se que lá existia um cartaz que dizia: Aqui não dança pretos! É bom evitar de frequentar esta casa, tão mal vista; deveis procurar outro logar para divertirem-se, eu compreendo que, todo o homem que tem brio e vergonha, passando por uma outra não torna. ${ }^{185}$

O pagamento das mensalidades e o bom comportamento em relação às obrigações dos sócios continuava a ser preocupação dos tesoureiros dos jornais:

COMUNICAÇÕES DE PAGAMENTO À PRAÇA

Sociedade Recreativa Ytuana: O sr. Ignacio de Almeida, muito digno desta sociedade, nos communicou que a sociedade acima liquidou com todas as dividas que existiam, nada devendo a praça, tendo mais registrado os seus estatutos conforme manda a lei. Nossos parabéns. ${ }^{186}$

\footnotetext{
${ }^{183}$ A Liberdade, 14 julho 1919, n.1, p.1

${ }^{184}$ A Liberdade, 9 maio 1920, n.15, p.1

${ }^{185}$ Idem, p. 2

${ }^{186}$ A Liberdade, 1 fevereiro 1920, p. 3
} 
Em outra ocasião, o anúncio dos devedores era feito de forma bastante curiosa: utilizando-se do humor como estratégia para sensibilizar os maus pagadores, tentava-se assim obter os recursos necessários à manutenção do periódico:

\footnotetext{
Por não pagarem o rateio da "A Liberdade", foram sepultados nesta quadra as seguintes pessoas:

D. Maria de Paula Barros, Julia Macedo Costa, Maria da Conceição, Benedicta de Castro, Izaura do Carmo, Eudoxia dos Santos e Anna Martyr de Oliveira e os Srs. Alfredo Eugenio da Silva (Alfredinho), Antonio Duarte, Benedicto Antonio dos Santos, Francisco de Paula Souza, Narciso Gervazio e Paulo Alves. Descanço eterno. $^{187}$
}

Gastão Rodrigues, citado vários vezes nas páginas de $O$ Bandeirante, destacava-se como verdadeiro líder na comunidade negra, preocupado não somente com o que se passava nos bailes e associações, mas também com os aspecto culturais e educativos, além da conquista da cidadania por parte dos jovens:

\section{AOS CIDADÃOS BRAZILEIROS}

Aos Cidadãos Brazileiros : todos os brazileiros que desejarem alistarem eleitores no districto de Villa Marianna, afim de formar um bloco de rapazes de côr deverão procurar o snr. Gastão Rodrigues da Silva, que està encarregado de fazer a qualificação para aquelle bairro. ${ }^{188}$

O jornal publicava a maioria dos anúncios na última página. Os principais anunciantes eram a Casa Bom Gosto, a Casa Orciuolo, a Loção Jacy e a Typographia Ferrari \& Buono, que se mantiveram do primeiro ao último número. Esses estabelecimentos localizavam-se à Rua Vergueiro, no Largo do Riachuelo e à Avenida São João, respectivamente.

É interessante, mais uma vez, analisar a importância financeira dos anunciantes na manutenção dos jornais. No caso de $A$ Liberdade, o primeiro número trazia 13 anunciantes distribuídos em três das cinco páginas publicadas. A Casa Orciuolo e a Casa Bom Gosto possuíam dois anúncios em páginas diferentes. Em maio de 1920, o número de anunciantes caiu pela metade, mantendo-se praticamente inalterado até setembro do mesmo ano, com sete. Já em outubro, no último número a que tivemos acesso, não existem anunciantes nas três páginas publicadas.

$$
* * *
$$

Em 17 de junho de 1992 começou a circular em São Paulo O Kosmos, jornal de propriedade do Grêmio Dramático e Recreativo Kosmos. Segundo José Correia Leite, “foi um

\footnotetext{
${ }^{187}$ Idem, ibidem.

${ }^{188}$ Idem, ibidem
} 
jornal sério, que se preocupava muito com atividades culturais. Seu diretor, Francisco Batista de Souza, foi secretário da Faculdade de Direito do Largo São Francisco, e colaborou no jornal $O$ Clarim". ${ }^{189}$ A publicação era mensal, mas ocorriam alguns atrasos. A assinatura anual custava $5 \$ 000$ réis, a semestral $3 \$ 000$ e o exemplar avulso $\$ 200$. Somente aceitava colaborações dos assinantes e toda correspondência deveria ser entregue à Rua Florencio de Abreu n.45, que também era a sede do Grêmio.

O jornal se apresentava com o subtítulo Orgam Official do Gremio Dramatico e Recreativo Kosmoa, pois mesmo as noticias sobre a comunidade negra, os textos críticos e literários enfatizavam a influência dessa associação em seu discurso de exaltação da raça negra:

E quem nos dirá que para o futuro [o Kosmos] poderá ser ainda o porta-voz dos homens de côr? Depende isso, sómente, da boa união e força de vontade dos jovens amantes das letras, competentes, para se tornar em facto "aquillo que mais necessitamos, um defensor da classe". ${ }^{190}$

Havia também uma coluna chamada "Ideas dos outros", onde eram publicadas piadas, e outra denominada "Provérbios". Na coluna "Observando", criticava-se o comportamento inadequado dos negros dentro de uma lógica puritana e machista:

Diariamente os jornaes criticam justa e benevolamente o actual exagero da moda, que em geral, as senhoras adoptam nos seus vestuarios, prejudicando assim, - a moral e o physico. São bem desnecessários os decotes descommunaes, os braços nus, a demasiada pintura, que forçosamente virá estragar a belleza feminina.

As senhoras que vivem captivas da moda, tornando-se uma boneca, um objeto de luxo, unica e exclusivamente para prender a attenção do homem, terá fatalmente que ver fracassado o seu falluz imperio, com o sello horrível do tempo; - a velhice, lhe imprime na face.

O recato e o pudor, davam melhor brilho a belleza feminil; a modestia concorria para o encanto irresistível de mulher...Hoje; é ridículo, é mesmo criticavel!

Se todas refletissem, não adoptando os trajes berrantes e os gestos desabridos, haveria do sexo forte mais respeito e os seus encantos, não seriam severamente ultrajados pela crítica. A mulher só por si, predomina o homem, com a esthetica da sua belleza. ${ }^{191}$

A seguir, outra coluna chamada "Dizem que..." onde se comentava a respeito de alguns membros da comunidade, nem sempre de forma negativa, mas muitas vezes apenas para comunicar o que estavam fazendo e sobre quais temas estavam trabalhando para o interesse do Grêmio. Nessa seção pudemos identificar alguns pontos de encontro da

\footnotetext{
${ }^{189}$ IN: FERRARA, Miriam Nicolau. Op. Cit., p 54.

${ }^{190}$ O Kosmos, 22 junho 1924, n.25, p.1

${ }^{191}$ O Kosmos, nov. 1922, p.2
} 
comunidade do Kosmos, como o Largo do Tesouro, o Largo 7 de Setembro e Líbero Badaró. Havia também menção à compra de lotes de terreno para construção de uma futura sede do Kosmos em Quitaúna. ${ }^{192}$

Os sócios que atrasavam pagamento eram sutilmente repreendidos em uma nota entre outras da mesma coluna ${ }^{193}$.

Identificamos também uma nota na seção "Notas Sociaes", que se dedicava ao cotidiano das outras associações, mencionando uma entidade ligada ao movimento operário em São Paulo:

\section{REVISTA}

Recebemos e agradecemos a bem elaborada Revista Commemorativa do $5^{\circ}$ anniversário da "União dos Trabalhadores Graphicos".

Mesmo não sendo tão efetiva e tendo registrado alguns conflitos, a participação de entidades e representantes do movimento operário em reuniões e eventos das associações e jornais negros existiu em São Paulo, tema que comentaremos mais à frente.

O Kosmos também denunciava a discriminação e o preconceito, pari passu a distribuição da população em São Paulo:

Lá no monte eleva-se um castello, mais além, outro e outro. Cá em baixo, um casebre rustico na apparencia e humilde no estylo, porem, encerrando em seu todo um passado de glorias e conquistas. (...)

Nos castellos que se erguem nobres pelo effeito da arhitectura, que se elevam orgulhosos pelo trabalho artístico, só se premiditam os crimes e as infamias!(...)

Contraste!

O casebre é o tempo da educação e do ensino, os castellos antros da depravação e da deshonra. Aquele, dá luz e compreensão, ao passo que estes encerram crimes e devassidões! ${ }^{194}$

O jornal praticamente não registrava anúncios publicitários, mas foi um dos primeiros a apresentarem um balanço financeiro da entidade que representava, nesse caso, o Grêmio Kosmos. Em 1924, as maiores fontes de receitas provinham das mensalidades e dos rateios para festas, com aproximadamente 2 contos de réis cada, enquanto as despesas mais significativas eram geradas com a orquestra para os ensaios, que custava 1 conto de réis, e com o salão, que custava mais de 1 conto e quatrocentos mil réis. $O$ total de ativos da entidade somava 7:538\$106 réis, e o Grêmio chegou a destinar 231\$600 réis ao jornal.

\footnotetext{
192 O Kosmos, 22 junho 1924, n. 25, p.2

193 "Os socios em atrazo, no proximo mez, terão a honra de ver seus nomes em letra de forma", idem, ibidem.

${ }^{194}$ Idem, ibidem, p.8. IN: FERRARA, Miriam Nicolau. Op. Cit., pp.102-103
} 
Foi possível notar que todos esses primeiros jornais de São Paulo mantiveram em comum o aspecto cultural e informativo e os assuntos específicos e pertinentes à comunidade negra. As dificuldades também estavam sempre presentes, tais como esforços para arregimentar assinantes e a necessidade de manter as finanças em dia, a fim de manter a continuidade das publicações. Infelizmente, e na maioria das vezes, isso não ocorreu. Roger Bastide assim definiu essa imprensa naquele período:

Em primeiro lugar, raramente, é uma imprensa de informação: o negro letrado lê o
jornal dos brancos, é uma imprensa que só trata de questões raciais e sociais, que só
se interessa pela divulgação de fatos relativos à classe da gente de cor. (...) Esses
jornais procuram primeiramente agrupar os homens de cor, dar-lhes o senso da
solidariedade, encaminhá-los, educá-los a lutar contra o complexo de inferioridade,
superestimando valores negros, fazendo a apologia dos grandes atletas, músicos,
estrelas de cinema de cor. É, pois, um órgão de educação. Em segundo lugar, é um
órgão de protesto. (...) Outro caráter comum a toda a imprensa afro-americana é a
importância dada à vida social, às festas, aos bailes, as recepções, aos nascimentos,
casamentos e mortes - a exigência sociológica de mostrar seu status social e sua
honrabilidade.

Embora correta, as afirmações do estudioso francês suscitam outras. Se os jornais concentraram suas forças e atenção nos assuntos relativos aos homens de cor e aos eventos sociais, o fizeram mediante a simples razão de que os negros não dispunham de um veículo de comunicação que pudesse agregá-los em busca de melhores condições de vida em uma sociedade de brancos moldada para atender os interesses dos brancos, uma sociedade que o rejeitava e lhe dificultava o acesso à educação e ao trabalho.

Por outro lado, o protesto contido nas manifestações escritas e trazidas ao público negro através dos editoriais desses jornais é veemente. Se o aspecto social e recreativo o superava em quantidade, o eco das notícias de abusos, de discriminação e preconceito raciais, da luta contra a apatia do negro e da necessidade de mudanças se fazia sempre ouvir, de uma maneira ou de outra, fosse nos jornais, fosse nos clubes e nas associações.

Passada essa primeira fase (1915-1922), entre eventos sociais, e modestas, mas sempre presentes formas de reivindicação, a imprensa negra cresceu ainda mais, desenvolveuse e consolidou-se. E dentro desse cenário, Getulino, O Clarim da Alvorada e a Frente Negra Brasileira foram os maiores protagonistas.

${ }^{195}$ BASTIDE, Roger. A imprensa negra de São Paulo...p.51 


\section{Capítulo 4 - Evolução da Imprensa negra no quadro histórico paulista}

A historiografia sobre São Paulo vem se ampliando crescentemente nas últimas décadas e o início deste capítulo retrata um quadro já conhecido. No entanto, achamos útil relembrar alguns momentos do processo histórico paulista, a fim de melhor situar o tema de que nos ocupamos.

Nos primeiros anos da década de 1920, São Paulo experimentou uma fase extraordinária de crescimento, impulsionada principalmente pela hegemonia conquistada em relação à produção e comercialização de café. $\mathrm{O}$ parque industrial cresceu rapidamente nas três primeiras décadas de República, empregando um número de trabalhadores quatro vezes maior que o do início do século, concentrado principalmente na indústria têxtil e de alimentação. A cerâmica, a marcenaria, o fabrico de chapéus e a produção de calçados também se expandia.

Após a Primeira Guerra Mundial, a restrição de importações beneficiava a indústria local, que finalmente podia competir em melhores condições com produtos estrangeiros. A malha ferroviária convergia para o mercado de café de São Paulo, estendendo fronteiras e trazendo para a cidade divisas provenientes do norte do Paraná, sul do Mato Gross e Minas Gerais. São Paulo já se tornava destaque nacional na indústria, tornando-se independente do Rio de Janeiro.

Estado e cidade eram símbolos do progresso e da modernidade nacionais. Desde o final do século XIX as elites enriquecidas pela exportação cafeeira deixavam o interior e iniciavam uma remodelação do espaço, adaptando a cidade a seus gostos e ao seu ideário, dententoras que eram do poder econômico e político, apagando traços que lembrassem o passado pacato e provinciano. A população, entre 1910 e 1920, já havia crescido mais de $60 \%$. A cidade convivia com as carroças e animais de carga cortando o centro, atrapalhando o fluxo comprometido por ruas estreitas e tortuosas, ao mesmo tempo que a presença de automóveis e bondes elétricos era cada vez mais constante. O parque do Anhangabaú, os novos jardins da praça da República, a nova praça da Sé, o viaduto do Chá e o Teatro Municipal já faziam parte de uma cidade conhecida por seus contrastes:

Em 1900, é aberta a avenida Paulista. Santana, Vila Gomes Cardim, Vila Prudente, Ipiranga e Vila Cerqueira César são arruamentos isolados, separados da cidade propriamente dita por áreas não loteadas. Penha e Pinheiros crescem bastante. Nos municípios vizinhos o crescimento demográfico se acelera. Ao longo das estações ferroviárias, nascem pequenos aglomerados dedicados ao comércio - os subúrbios 
da metrópole atual. Em alguns deles, surgiriam indústrias de beneficiamento e transformação de matérias-primas (madeiras, produtos cerâmicos, cal, papel, extração de pedras, combustíveis, materiais para construção, madeira para móveis).

Em 1910, inaugura-se o Jardim América, depois o Jardim Paulista e o Jardim Europa, cujas residências têm caráter diferente dos modelos urbanísticos do passado: os tradicionais jardins fechados são substituídos pelos de estilo inglês; o crescimento urbano chega ao bairro de Pinheiros; surgem novos arruamentos, ordenados e localizados segundo a iniciativa individual dos proprietários de terrenos. São dessa época: Vila Tietê (Casa Verde), Vila da Saúde, Lapa, Vila Leopoldina e Carandiru. ${ }^{196}$

Nos traços de Voltolino $^{197}$, a seguir, as obras de modernização que visavam a atender necessidades prementes da população eram tratadas ao mesmo tempo com bom humor e senso crítico, como se pode ver pelas imagens com que exemplificamos a afirmação:

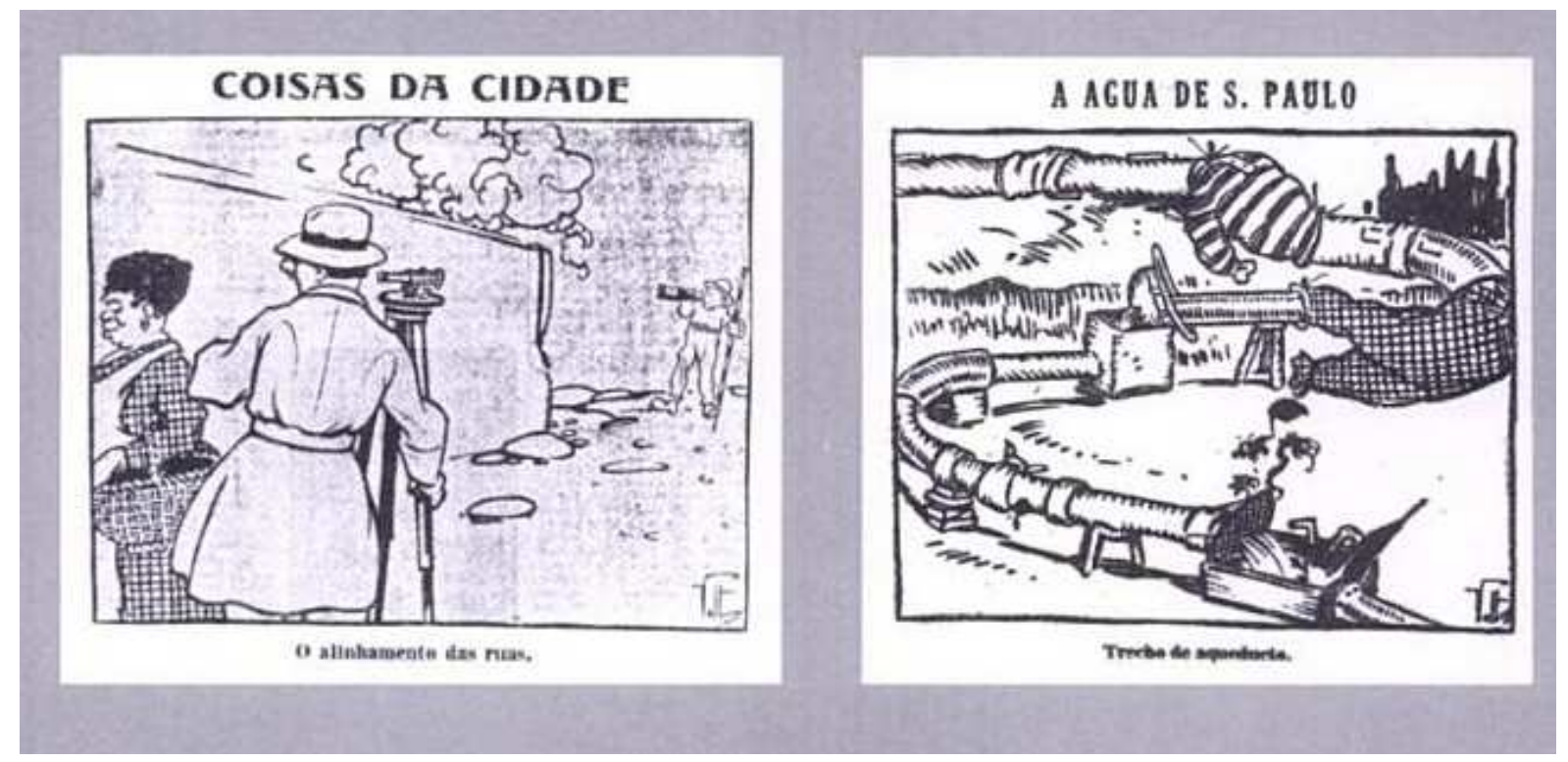

Fig. 3 (esquerda): Voltolino - “Coisas da Cidade” - O Estado de São Paulo (edição vespertina) - 15 mai 1920 Figura 4 (direita): Voltolino - "A Àgua de S. Paulo” - O Estado de São Paulo (edição vespertina) - 22 jan 1920

196 DIAS, Márcia Lúcia Rebello Pinho. Desenvolvimento urbano e habitação popular em São Paulo (18701914). São Paulo: Ilustrada, 1989, p. 29.

197 João Paulo Lemmo Lemmi (1884-1926), mais conhecido por Voltolino, foi um famoso caricaturista, desenhista e ilustrador, além de assíduo colaborador de jornais, entre eles $O$ Estado de São Paulo, O Pirralho, de Oswald de Andrade, e a revista carioca $O$ Malho. Para maiores informações sobre Votolino, ver BELUZZO, Ana Maria de Moraes. Voltolino e as raízes do modernismo. Dissertação de Mestrado. Escola de Comunicação e Artes da Universidade de São Paulo - ECA/USP, São Paulo, 1980. 

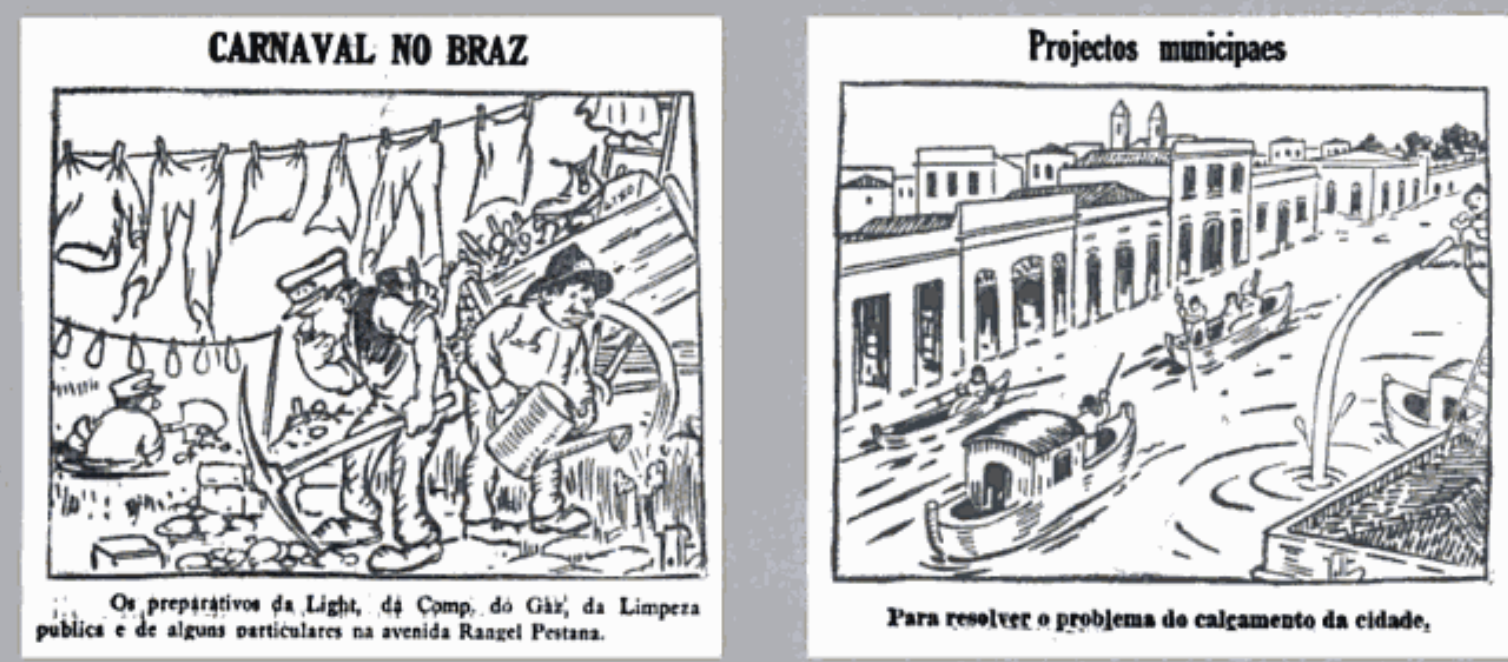

Para resolves o problema do calsamento da eidade,

Fig. 5 (esquerda): Voltolino - “ Carnaval no Braz” - O Estado de São Paulo (edição vespertina) - 22 jan 1921 Figura 6 (direita): Voltolino - "Projectos municipaes” - O Estado de São Paulo (edição vespertina) - 22 jan $1921^{198}$

No início da década de 1920, São Paulo também vivenciava outro nível de mudanças, relacionadas a um processo de adaptação e recuperação. O final da Primeira Grande Guerra representava alegria e alívio para a população paulistana, pois a Alemanha finalmente assinava o armistício com a Tríplice Entente - França, Rússia e Inglaterra. Porém, um surto de gripe espanhola deslustrava o momento de euforia, fazendo milhões de vítimas no mundo inteiro. Cerca de um terço da capital bandeirante foi atingido durante o período mais crítico da doença, fazendo emergir a precariedade da organização hospitalar e sanitária, latente desde o final do século XIX.

Cabe lembrar que, graças à debil estrutura para controle de epidemias na cidade, já havia ocorrido um terrível surto de cólera em 1893, provocando mudanças de hábito e inúmeras discussões junto ao Poder Público sobre a necessidade de uma plano de saneamento para a São Paulo.

O número de óbitos atingiu a marca de 8 mil pessoas naqueles 45 dias mais críticos da gripe espanhola na cidade de São Paulo. Além de rever a capacidade hospitalar, as autoridades da época recomendavam a remoção imediata de doentes aos hospitais. Os principais eram o Hospital de Isolamento (hoje Emílio Ribas), criado em 1896 na então

\footnotetext{
198 IN: SEGAWA, Hugo M. Prelúdio da Metrópole: arquitetura e urbanismo em São Paulo na passagem do século XIX ao XX. São Paulo: Atelie Editorial, 2000 (2ª edição), pp.56-57
} 
Estrada do Araçá (a atual Avenida Dr. Arnaldo), para tratamento de epidemias, principalmente a varíola; a Beneficência Portuguesa, o Hospital Matarazzo e o Hospital Oswaldo Cruz, construídos por iniciativa de imigrantes portugueses, italianos e alemães, respectivamente. Havia ainda a Maternidade São Paulo, destinada às mães pobres, a qual viria a ser considerada a maior da Capital.

Naquela época, a população negra de São Paulo foi duramente atingida, exatamente por se tratar de uma das mais pobres:

A gripe espanhola foi pior que a Aids; dizimou centenas de pessoas. Foi durante a
guerra na Europa e trazida por ratos nos navios. Mas eu afirmo: matou negro que
não acabava mais. Sei disso porque em minha volta eram só conhecidos que
morriam. ${ }^{199}$
Tenho uma lembrança que gostaria de esquecer. Era 1918, esse ano foi o da peste
chamada gripe espanhola. Foi igual à Aids, claro que matou mais nossa gente, nós
éramos pobres. ${ }^{200}$

A cidade também respirava um ar de mudança (já não tão puro) em relação ao cotidiano operário. São Paulo havia experimentado uma paralisação significativa em 1917, quando trabalhadores de uma grande empresa da indústria têxtil interromperam suas atividades por mais de trinta dias. O mesmo ocorreu em 1919, quando gráficos, padeiros, trabalhadores da construção civil, serralheiros, entre outros operários, cruzaram os braços. Em comum, existiam as reivindicações sobre o cumprimento da jornada de trabalho de 8 horas diárias e a melhoria das condições das fábricas e dos salários. As paralisações passam a ser tratadas pelo governo como caso de polícia. Com efeito, a reivindicação dos movimentos operários havia forçado o governo a legislar sobre as relações de trabalho, tema sobre o qual a burguesia industrial resistirá intensamente. Na década seguinte, porém, será a elite agrária quem irá conduzir esse processo, visando a aumentar suas bases sociais, mesmo porque o trabalhador rural ficará fora desse contexto de reformulação.

A crítica situação da saúde e do emprego era reflexo do rápido crescimento populacional e econômico experimentado pela cidade desde o início do século $\mathrm{XX}$, principalmente em função do desenvolvimento industrial, como se pode ver linhas atrás. $\mathrm{O}$ êxodo rural gerado pela crise cafeeira de 1901, por exemplo, traz aos centros urbanos, em particular a São Paulo, uma mão-de-obra relativamente qualificada e barata, decorrente do abandono dos cafezais pelos imigrantes. Tal movimento, iniciado nos anos 1880, irá

\footnotetext{
${ }^{199}$ Depoimento pessoal do Sr. Cassiano tomado por Teresinha Bernardo IN: BERNARDO, Teresinha. Memória em branco e negro: olhares sobre São Paulo. Universidad Pontificia de Comillas de Madrid, 1998, p. 110.

${ }^{200}$ Depoimento pessoal do Sr. Antonio. Idem, ibidem, p. 110
} 
robustecer e modificar o mercado de trabalho no ambiente urbano, onde a indústria irá abastecer-se ${ }^{201}$.

No início do processo de industrialização, o excedente obtido com a produção de café serve à acumulação de capital, favorecendo o desenvolvimento do capitalismo no Brasil. Como um resultado desse crescimento, temos um investimento significativo em eletrificação e urbanização. A potência elétrica no Brasil, que em 1890 representava 10.350 cavalos-força, passa a 60.778 C.V. em 1905 e 203.901 em 1910, alcançando mais tarde, em 1925, $475.652^{202}$. Entre 1872 e 1920, a população da cidade de São Paulo cresceu de 31.385 para aproximadamente 580 mil pessoas ${ }^{203}$.

Igualmente vertiginoso é o crescimento no número de empresas nas primeiras duas décadas dos anos 1900, conforme demonstrado no quadro a seguir:

\begin{tabular}{|c|c|c|c|c|c|c|c|c|}
\hline \multirow{2}{*}{ Ano } & \multicolumn{4}{|c|}{ Brasil (A) } & \multicolumn{4}{c|}{ Estado de São Paulo (B) } \\
\cline { 2 - 9 } & $\begin{array}{c}\text { Número } \\
\text { de } \\
\text { Empresas }\end{array}$ & $\begin{array}{c}\text { Capital } \\
\text { (Contos) }\end{array}$ & $\begin{array}{c}\text { Força } \\
\text { Motriz } \\
\text { (CV) }\end{array}$ & $\begin{array}{c}\text { Número } \\
\text { Operários }\end{array}$ & $\begin{array}{c}\text { Número } \\
\text { de } \\
\text { Empresas }\end{array}$ & $\begin{array}{c}\text { Capital } \\
\text { (Contos) }\end{array}$ & $\begin{array}{c}\text { Força } \\
\text { Motriz } \\
(\mathrm{CV})\end{array}$ & $\begin{array}{c}\text { Número } \\
\text { Operários }\end{array}$ \\
\hline 1907 & 3.258 & 653.555 & 109.284 & 149.018 & 326 & 127.702 & 18.301 & 24.186 \\
\hline 1920 & 13.336 & 1.815 .156 & 310.424 & 275.512 & 4.145 & 537.817 & 94.099 & 83.998 \\
\hline $\begin{array}{c}\text { Crescimento } \\
(\%)\end{array}$ & $\mathbf{3 0 9 \%}$ & $\mathbf{1 7 8 \%}$ & $\mathbf{1 8 4 \%}$ & $\mathbf{8 5 \%}$ & $\mathbf{1 1 7 1 \%}$ & $\mathbf{3 2 1 \%}$ & $\mathbf{4 1 4 \%}$ & $\mathbf{2 4 7 \%}$ \\
\hline
\end{tabular}

Fontes: Le Brésil et ses richesses, vol. II, p. 373; e Recenseamento de 1920, Vol. V, pp. XXII e XXIII; Ministério da Agricultura, Indústria e Comércio, Brasil Atual, Rio de Janeiro, 1930; Secretaria da Agricultura, Indústria e Comércio do Estado de São Paulo, Estatística Industrial do Estado de São Paulo, São Paulo, 1930. As duas últimas fontes são citadas por Boris Fausto, A Revolução de 1930, Editora Brasiliense, São Paulo, 1970, p. 23 IN: SILVA, Sérgio. op.cit., pp. 72-73.

Podemos notar que os indicadores da indústria do Estado de São Paulo superam amplamente o conjunto manufatureiro nacional em um período de apenas 13 anos. São Paulo ultrapassava o Rio de Janeiro (então Distrito Federal), que figurava em primeiro lugar no censo industrial de 1907 como centro mais importante. De um total de 2.498 .836 contos de

\footnotetext{
${ }^{201}$ Sobre o êxodo rural para as cidades, ver SIMONSEN, Roberto. Evolução Industrial do Brasil e outros estudos. Companhia Editora Nacional e Editora da USP, São Paulo, 1973.

202 Cf. Recenseamento de 1920 - Estatísticas Complementares,citado por NORMANO, J.F. Evolução Econômica do Brasil, Companhia Editora Nacional, São Paulo, 1939, p. 144 IN: SILVA, Sérgio. Expansão Cafeeira e Origens da Indústria no Brasil. 7ª Edição. São Paulo. Editora Alfa-Omega, 1986, p.93.

${ }^{203}$ Cf. ALESSIO, Nancy. Urbanização, Industrialização e Estrutura Operacional, Dados, n. 7, 1970 IN: Idem, ibidem.
} 
réis relativos ao valor da produção em 1920, os paulistas eram responsáveis por 39.46\%, seguidos do Distrito Federal, com $26.67 \%{ }^{204}$. A participação da indústria paulista no total da brasileira no mesmo período pode ser analisada da seguinte forma:

\begin{tabular}{|c|r|r|r|r|}
\hline \multirow{2}{*}{ Ano } & \multicolumn{3}{|c|}{ Peso de São Paulo na Indústria Brasileira } \\
\cline { 2 - 5 } & $\begin{array}{c}\text { Número } \\
\text { de } \\
\text { Empresas }\end{array}$ & $\begin{array}{c}\text { Capital } \\
\text { (Contos) }\end{array}$ & $\begin{array}{c}\text { Força } \\
\text { Motriz } \\
\text { (CV) }\end{array}$ & $\begin{array}{c}\text { Número } \\
\text { Operários }\end{array}$ \\
\hline 1907 & $10 \%$ & $20 \%$ & $17 \%$ & $16 \%$ \\
\hline 1920 & $31 \%$ & $30 \%$ & $30 \%$ & $30 \%$ \\
\hline
\end{tabular}

Somente o número de empresas cresceu 21 pontos percentuais entre 1907 e 1920, sendo localizado nesse quesito o maior incremento. Contudo, é de se concordar com Sérgio Silva quando diz que as grandes empresas dominavam o cenário industrial em São Paulo, tanto no período inicial quanto final de nossa análise. Aquelas com 100 operários ou mais concentram $80 \%$ do total de operários em 1907, enquanto esse percentual passa a ser de $65 \%$ em 1920. O total de empresas nessa faixa irá de 70 para 147, e o número de empregados para esse tipo de entidade cresce de 19.414 para 54.123 no mesmo período. Ou seja, o número de empresas mais que duplicou, enquanto o de operários quase triplicou. Entretanto, a produção agrícola ainda é fundamental, pois em 1920 o setor primário abrange $69.7 \%$ da população ativa, o secundário $13.8 \%$ e o terciário $16.5 \%$ 205.

Não é díficil imaginar que essa pujança não apresente sua fatura com a mesma rapidez. Os trabalhadores industriais e urbanos ocupavam massivamente os bairros operários mais antigos, como o Brás e a Mooca, Belém, Belenzinho e Pari na "zona" leste da cidade; Barra Funda, Bom Retiro e Bela Vista, na área mais central; trechos da Lapa, Água Branca, na região oeste; Cambuci e Ipiranga, na direção sudeste. Além dessas localidades, estabeleciam em outros lugares mais distantes, como a Penha, trechos do bairro de Pinheiros e áreas decadentes do centro. Todos muito populosos.

Ao longo da década de 1920, contrastando com o aparecimento frenético dos palacetes e da renovação urbana das áreas centrais, a cidade ainda convivia com as características desses bairros "populares", como Brás e Penha, com seus pântanos, ruas inteiras feitas em

\footnotetext{
${ }^{204}$ Recenseamento do Brasil - 1920 IN: FAUSTO, Boris. A Revolução de 1930: historiografia e história. 16a Edição. São Paulo, Companhia das Letras, 2008, p.38

${ }^{205}$ FAUSTO, Boris, op. cit., p.39
} 
série, habitações pobres e coletivas, pequenas oficinas ou grandes fábricas, minúsculo comércio, deficiente sistema de águas e esgotos, etc.

As famílias operárias geralmente pagavam aluguel, morando em casas individuais de três ou quatro cômodos e não possuíam casa própria. As casas próprias, por sua vez, também apresentavam as mesmas características das alugadas. No entanto, a maioria vivia em habitações coletivas: vilas, cortiços e porões, sendo estes dois últimos os tipos mais precários na década de 1920:

\begin{abstract}
Chamou-nos a atenção o tipo clássico de cortiços que se nos deparou frequentemente: um agrupamento de quartos dando para uma área estreita, em comum, cheia de vasos, com roupas estendidas ao sol, que aliás, aí regateia os seus raios que raramente aí penetram. Ao lado de cada porta, há o clássico fogareiro de lata de querosene.

(...)

Há também os cortiços gênero-porão.

Encontramos muitos deles, na maioria cimentados, outros atijolados e outros ainda têm simplesmente o piso de terra batida.

A entrada de muitos deles é feita por um respiradouro, sendo necessária uma ginástica forçada para neles penetrar, ou como melhor o possa. É claro que não foram feitos para serem habitados, pois neles há tudo que se contrapõe à higiene, mas, à falta de habitação e ganância dos proprietários, faz destas covas - moradas ${ }^{206}$.
\end{abstract}

À semelhança dos operários industriais, os negros sofriam com as condições de habitação na Capital. As pesquisas mostraram que mesmo a maioria dos líderes "letrados" da imprensa negra vivia precariamente, sobretudo em cortiços e porões, nos bairros da Liberdade e do Bexiga, uma realidade que os acompanhava desde o início do século XX.

O relato de Jacob Penteado é revelador sobre o estado de exclusão vivido pelos negros e a forma como eram discriminados pelos brancos:

Conta que, nos anos de 1910, viviam negros no Belenzinho, em "ajuntamentos" de casebres em um terreno aos fundos de uma chácara na Rua Conselheiro Cotegipe. Conta também, que os moradores das imediações "aguardavam com justificado aborrecimento" a comemoração da Abolição no dia 13 de maio. Desde a véspera, "começavam a chegar negros que nem formiga". A festa varava a noite, era animada pelo samba de roda "sob o som infernal dos instrumentos de percussão" e acabava em promiscuidade. Diz ainda que moleques do bairro uniam-se em coro para

\footnotetext{
${ }^{206}$ MELLO, Francisco Figueira. Habitações Collectivas em São Paulo, IN Boletim da Sociedade de Medicina e Cirurgia de São Paulo, vol. IX, 3ª Série, junho de 1926, n. 4, pp. 291-5, apud DECCA, Maria Auxiliadora Guzzo. A vida fora das fábricas: cotidiano operário em São Paulo (1920-1934). São Paulo: Editora Paz e Terra, 1987, pp. 30-31.
} 
ridicularizar o chefe dos negros - Barnabé - que "de gênio manso, olhava a criançada e sorria bonachão ${ }^{207,}$

Para tentar "sanear" essa questão, na década de 1920, paralelamente ao processo de renovação urbana e higienização das áreas centrais, os serviços de higiene e saúde passaram a ficar mais especializados. O conhecimento científico é mais valorizado em detrimento do "empírico". O Instituto de Higiene (Escola de Saúde Pública) de São Paulo, fundado em 1918, passa a coordenar atribuições "técnicas" e "pragmáticas" do Serviço Sanitário, incluindo as que são destinadas ao proletariado urbano e camadas mais pobres da população (centros de saúde, inspetorias de higiene infantil, ambiente de trabalho, propaganda e educação sanitária, etc). Naquele ano foi criado um "Laboratório de Higiene", sob convênio celebrado entre o governo do Estado de São Paulo e a Fundação Rockefeller, passando o mesmo a funcionar como uma cadeira da Faculdade de Medicina de São Paulo.

Trata-se de reflexo direto do crescimento exponencial da cidade e da experiência amarga com as epidemias.

Pode-se notar também que as iniciativas do Poder Público são reflexo de um momento de transição e mudanças. Se de um lado, a grande massa trabalhadora sofria com a crescente pauperização, a burguesia industrial desfrutava da riqueza crescente, se preocupava com hábitos sociais e gostos diversificados e ansiava romper com o atraso do passado. Dentro desse cenário, a elite paulista presenciou um evento que somente anos mais tarde teria seu devido reconhecimento: o surgimento do movimento modernista.

Entre os dias 13 e 17 de fevereiro de 1922, palestras, conferências, exposições de pintura e desenho, leituras de poesia e prosa foram apresentados ao público no Teatro Municipal de São Paulo na forma de uma festa pública. Rompia-se com o convencionalismo que então vigorava nas artes e na literatura, evitava-se o pieguismo da obra romântica e caminhava-se em direção contrária à imitação simplória dos modelos estrangeiros, tendo por ênfase a produção artística e literária baseadas na realidade brasileira. Figuras de destaque da sociedade nacional, como Villa-Lobos, Guilherme de Almeida, Oswald e Mário de Andrade, Menotti del Picchia, entre outros, fizeram parte do movimento que derrubou tabus e valores

${ }^{207}$ PENTEADO, Jacob. Belenzinho 1910: retrato de uma época. São Paulo, Martins, p. 172, 215-218. IN: ANDRADE, Margarida Maria de. Brás, Moóca e Belenzinho: formação e dissolução dos antigos bairros "italianos" além-Tamanduateí. Travessia - Revista do Migrante. AnoXIII, número 38, setembro-dezembro 2000. 
culturais, sendo fundamental para influenciar todo o meio urbano-industrial que seria formado dali em diante no país.

Anos adiante, Mario de Andrade resumia o que significou "a semana" dentro do contexto histórico da época:

\begin{abstract}
Manifestado especialmente pela arte, mas manchando também com violência os costumes sociais e políticos, o movimento modernista foi o prenunciador, o prepararador e por muitas vezes o criador de um estado de espírito nacional. A transformação do mundo com o enfraquecimento gradativo dos grandes impérios, com a prática europeía de novos ideais políticos, a rapidez dos transportes e mil e uma outras causas internacionais, bem como o desenvolvimento da consciência americana e brasileira, os progressos internos da técnica e da educação, impunham a criação de um espírito novo e exigiam a reverificação e mesmo a remodelação da Inteligência nacional. Isto foi o movimento modernista de que a Semana de Arte Moderna ficou sendo o brado coletivo principal. (.... $)^{208}$
\end{abstract}

Naquele mesmo ano, com bem menos glamour, o país viu nascer outro tipo de movimento. Após vários incidentes envolvendo militares e governo, o país assiste à eclosão da chamada "Revolta dos 18 do Forte de Copacabana". Desencadeado em 5 de julho, na cidade do Rio de Janeiro, então capital em Distrito Federal, foi a primeira revolta do movimento tenentista, no contexto da República Velha. A insurreição foi rapidamente debelada pelo então presidente Epitácio Pessoa, que decreta o estado de sítio e o lega a Artur Bernardes, seu sucessor.

O novo governante viria a agir duramente contra qualquer oposicionismo, fosse de fonte militar ou civil. Tal atitude fez apenas aumentar o sentimento de revolta entre esses segmentos.

Pouco antes, no dia 25 de março, o Brasil testemunhava o aparecimento do Partido Comunista do Brasil (atual Partido Comunista Brasileiro - PCB), na cidade de Niterói, Estado do Rio de Janeiro. A entidade fundada por Astrojildo Pereira, Abílio de Nequete, Cristiano Cordeiro, Hermogênio da Silva Fernandes e outros foi colocada na ilegalidade logo no seu primeiro ano de existência por Epitácio Pessoa. Porém, sua atuação nos movimentos políticos e sociais do país são bastante conhecidos e já foram extensamente estudados por historiadores e pelo meio acadêmico em geral, não cabendo aqui uma revisão mais detalhada. Mas

\footnotetext{
${ }^{208}$ ANDRADE, Mário de. O Movimento Modernista. Trecho de conferência realizada na Casa do Estudante, Rio de Janeiro, 1942, publicada em Aspectos da Literatura Brasileira, São Paulo, Livraria Martins Editora, s/d, p. 231-255 (1ª. edição: 1943). IN: SCHWARTZ, Jorge e POWER, Elizabeth. Brasil, 1920-1950: da antropofagia a Brasília. MAB-FAAP, Museu de Arte Brasileira, 30 nov 2002 a 2 mar 2003.São Paulo: Cosac Naify Edições, 2002, p. 475
} 
acreditamos que não existam dúvidas sobre a inovação que o Partido trouxe para a realidade brasileira a partir daquele momento. ${ }^{209}$

Pudemos ver naquele instante a renovação da linguagem, a busca da experimentação e a ruptura com o passado nos setores cultural, político, social e econômico. Um passado ainda presente no contexto da República Velha, controlada pelas oligarquias cafeeiras e pela política do "café-com-leite". O capitalismo se desenvolvia no país e continuava gerando elevados lucros, consolidando o poder da elite paulista, ainda influenciada pelos padrões estéticos europeus tradicionalistas.

Dentro desse contexto, a imprensa negra continuava sua trajetória de conscientização do negro em relação à busca de sua identidade e obtenção da cidadania. O caminho a ser trilhado era o do acesso à boa educação pública, ao trabalho decente, à cultura, à participação política e à almejada elevação moral. Esse período, contudo, marca o início da postura de reivindicação direta, da valorização do negro como protagonista da História, da lembrança de seu papel na sociedade e da crítica à falta de ação dos próprios irmãos.

209 Sobre a história do Partido Comunista do Brasil, ver sítio do partido, disponível em <http://www.vermelho.org.br/pcdob/80anos/trajetoria.asp>; Ver também CARONE, Edgar. PCB (1922-1943). São Paulo: Bertrand Brasil, 1982. 


\subsection{Crescimento e desenvolvimento da Imprensa Negra}

\section{Getulino}

Como foi dito anteriormente, nossa proposta é redefinir a periodização dessa imprensa negra em São Paulo, a partir das lutas delineadas a partir das Irmandades e Associações Negras, passando pela atuação dos primeiros jornais. De uma maneira ou de outra, essas entidades já estavam envoltas pelo espírito da ação reivindicatória. Entretanto, a partir do início dos anos 1920, o movimento e as lideranças negras demonstrariam um amadurecimento inédito em comparação com períodos anteriores.

Miriam Nicolau Ferrara, em obra já citada, definiu o segundo período da atuação daqueles jornais a partir da fundação de O Clarim da Alvorada, em janeiro de 1924. A fundação, em 1923, de Getulino, na cidade paulista de Campinas, encerraria o primeiro ciclo:

Em 1923 encerra-se o primeiro período da imprensa negra, com o jornal "Getulino". A partir daí, as reivindicações e o desejo de participação irão ganhar força; é quando se inicia o segundo período que vai de 1924 a 1937.

Se neste segundo período a imprensa negra trata dos mesmos temas explorados no primeiro, agora o que o difere é a maneira de enfocá- $\operatorname{los}^{210}$.

Concordamos com o caráter de transição de uma imprensa já reivindicatória, mas pouco incisiva até então, para uma "produção jornalística" que "atinge seu ápice, sem palavras atenuantes, de forma direta e objetiva". Porém, em nosso entender, o jornal Getulino iniciaria o segundo período, pois já demonstrava essas virtudes antes de $O$ Clarim da Alvorada.

Os motivos em que nos fundamentamos são tão claros como as mensagens expressas nas tintas do Getulino: estabilidade na gestão do jornal e nas publicações, mensagens diretas, representatividade de seus redatores, a cooperação com diversos integrantes da imprensa negra paulista (Deocleciano do Nascimento e Jayme Aguiar, entre outros) e o relacionamento muito próximo com outros jornais (entre eles, O Kosmos, O Clarim da Alvorada). Em 1926, seus representantes (Lino Guedes, Gervásio de Moraes e Benedito Florêncio) se mudam para São Paulo, onde tentam dar continuidade ao terceiro ano do jornal, sem sucesso. A atuação desses militantes continua, porém através de outro periódico, "Progresso", fundado em 1928.

\footnotetext{
${ }^{210}$ FERRARA, Miriam. op. cit., p. 104
} 
A própria Miriam Nicolau Ferrara concorda com o que dizemos, numa contradição em relação ao que afirmou anteriormente, ou seja, que a segunda fase começaria em 1924. No entanto, volta atrás ao escrever:

É com o "Getulino" (1923-1926), jornal de Campinas, fundado por Lino Guedes e Gervásio de Moraes que se iniciam, efetivamente na imprensa negra, as reivindicações.

(...) Segundo informações, a imprensa negra combativa surge em Campinas por tratar-se de uma cidade mais racista do que a de São Paulo, onde as pressões contra o negro eram fortes ${ }^{211}$.

No início estes jornais refletem um caráter associativo e integrativo, mas é a partir de 1923 que vão assumir abertamente as reivindicações como instrumento de luta ${ }^{212}$

Veremos que, a partir de Getulino, as questões relativas ao negro são abordadas de forma mais enfática, colocando em relevo o preconceito e a discriminação, buscando a elevação moral do negro, mas também apontando os seus erros e os daqueles que tentam obstruir o seu caminho para a construção de uma identidade. O periódico campineiro representa, verdadeiramente, a mudança para o caráter reivindicatório da imprensa negra em São Paulo.

No entanto, os jornais negros de Campinas não se iniciaram com ele. Em 1903, passou a circular $O$ Baluarte, que não registra a presença de nenhum exemplar adicional à edição de janeiro de 1904 e tampouco encontram-se registros na imprensa daquela cidade. Um fato digno de nota é que o jornalista Benedito Florêncio, destacado militante campineiro, é um dos fundadores desse jornal, como o seria também em relação ao Getulino ${ }^{213}$.

Entre outros periódicos daquela cidade, destacou-se o União (cuja data de fundação é imprecisa, entre 1915 e 1917), fundado pelo jovem Lino Guedes, então revisor-chefe do Correio de Campinas. Muitas vezes, as figuras de Getulino e Guedes parecem querer confundir-se aos olhos menos atentos, tamanha a sua influência na orientação editorial do periódico.

Juntamente com Gervásio de Moraes e Benedito Florêncio, fundou o Getulino em 29 de julho de 1923, quando circulou o primeiro exemplar. O investimento inicial foi viabilizado através do aporte dos empreendedores Alcino de Moraes e dos irmãos Martinho e Christino José de Andrade. Seu título era inspirado no pseudônimo de Luiz Gama, em referência a seu trabalho poético mais conhecido - Trovas Burlescas do Getulino -, além de seu incansável

\footnotetext{
${ }^{211}$ Idem, ibidem, p. 54 (grifo nosso)

${ }^{212}$ Idem, ibidem, p. 83(grifo nosso)

213 Sobre outros jornais pertencentes á Imprensa Negra em Campinas, ver MACIEL, Cléber da S. Discriminações Raciais: negros em Campinas (1888-1921). Campinas, Editora Unicamp, 1987. Série Campiniana.
} 
trabalho abolicionista. A explicação para o nome do jornal encontra-se estampada na primeira página, quando estreou:

Getulino, nome de guerra do grande paladino da abolição, que foi o saudoso Luiz Gama, eis a denominação que escolhemos para a folha que hoje vem collocar-se em linha de combate na imprensa campineira ${ }^{214}$

Luiz Gama era o modelo a ser seguido e divulgado por Lino Guedes. O conhecido abolicionista é exemplo recorrente de superação no meio negro e presente em praticamente todos os jornais da imprensa negra, em São Paulo ou outros estados. Tornou-se escravo ainda criança, após ter sido vendido pelo próprio pai para pagamento de uma dívida de jogo, e desde muito cedo teve consciência de que era livre e que fora injustamente escravizado. Em uma de suas cartas biográficas, Luiz Gama fala da mãe, Luísa Mahin:

Sou filho natural de negra africana, livre, da nação nagô, de nome Luísa Mahin, pagã, que sempre recusou o batismo e a doutrina cristã. Minha mãe era baixa, magra, bonita, a cor de um preto retinto sem lustro, os dentes eram alvíssimos, como a neve. Altiva, generosa, sofrida e vingativa. Era quitandeira e laboriosa ${ }^{215}$.

Luísa Mahin Luísa Mahin (nascida no início do século XIX) foi uma ex-escrava africana, radicada no Brasil. Pertencia à tribo Mahi, da nação africana Nagô, praticantes da religião islâmica, conhecidos no Brasil como Malês. Embora se desconheça a sua origem, tendo vivido em Salvador, na Bahia, foi alforriada em 1812. Afirmava ter sido princesa na África. De sua união com um fidalgo português, nasceu Luiz Gama ${ }^{216}$.

Lino Guedes não escondia sua admiração por Luiz Gama, muitas vezes considerada exacerbada por alguns. Seu sentimento em torno do exemplo beirava a obsessão, além da idolatria. Quando em 1928 funda o jornal Progresso, na capital paulista, não faz segredo sobre o intuito de buscar recursos para erigir uma herma ao abolicionista negro no Largo do Arouche. Em 1923, foi sua a ideia de dar o nome ao jornal em homenagem ao orfeu de carapinha.

\footnotetext{
${ }^{214}$ Getulino, 29 jul. 1923, p.1

215 Carta biográfica de Luiz Gama a Lúcio de Mendonça, datada de 25 de julho de 1880. Disponível em <http://www.tropis.org/afro/luizgama.html>. Acesso em 21 de junho de 2009.

${ }^{216}$ Sobre Luiz Gama, ver AZEVEDO, Elciene. Orfeu de carapinha: a trajetória de Luiz Gama na imperial cidade de São Paulo. Campinas, UNICAMP, 1999, e MENUCCI, Sud. O precursor do abolicionismo no Brasil: Luiz Gama. São Paulo: Companhia Editora Nacional, 1938. Sobre Luísa Mahin ver SCHWARZ-BART, Simone; SCHWARZ-BART, André; DAVAL, Stephanie e VINOKUROV, Val. In Praise of Black Women: Heroines in the Slavery Era. University of Wisconsin Press, 2002. Disponível em <http://books.google.com.br/books?id=C5AfcnGEu-QC\&dq=luiza+mahin\&as_brr=3\&source=gbs_navlinks_s > Acesso em 19.08.2009.
} 
Era tão influente nos rumos do jornal como redator-chefe que é impossível não considerá-lo, muitas vezes levando tanto os admiradores como os detratores da Folha a julgarem-na baseados em seu principal artífice.

Esse jornalista nasceu em 24 de junho de 1897 na cidade de Socorro, interior paulista, filho de ex-escravos. Ficou órfão de pai aos dois meses de idade, tendo sido criado pela mãe, juntamente com a irmã, Gracinda, como o apoio e a "carinhosa filantropia" do líder político de Socorro, a quem chamava de "coronel" Olympio Gonçalves dos Reis, por quem Lino Guedes demonstraria eterna admiração e gratidão, referindo-se a ele como o "benemérito cidadão" que lhe "estendera a mão protetora". ${ }^{217}$

Em 1912, é contratado como revisor auxiliar no Diário do Povo, um jornal recém criado em Campinas. Após uma breve passagem pelo Correio de Campinas em 1918, volta ao Diário, onde permanece por algumas semanas, tendo se dirigido definitivamente para o Correio Popular, na mesma cidade.

Ao sair de Campinas, em 1926, fundou o jornal Progresso na capital paulista, além de ter trabalhado em diversos jornais da imprensa tradicional, como o Jornal do Comércio, $O$ Combate, A Razão, Correio Paulistano e, finalmente, no Diário de São Paulo, onde permaneceu até o falecimento, em 1951.

Suas grandes paixões eram a poesia e a imprensa negra, provavelmente nessa ordem, se bem que integradas entre si. Tendo publicado os primeiros versos poesias em jornais da imprensa negra em Campinas e São Paulo, conseguiu publicar seu primeiro livro de poesias somente em 1926, com o título de Black, seguido de mais onze obras, entre elas $O$ Canto do Cisne Preto (1926), e Negro Preto Cor da Noite (1936).

É importante dizer que seu período mais produtivo parece ter sido entre 1936 e 1938 , quando foram publicados não menos que sete livros, sem o apoio de uma editora. ${ }^{218}$ Por isso, é ele considerado por muitos como o precursor da negritude no Brasil. ${ }^{219}$ No entanto, o Getulino não se reduziu somente à sua figura central, como veremos mais adiante, pois julgamos extremamente importante conhecermos as pessoas que estavam por trás daqueles textos.

\footnotetext{
${ }^{217}$ Getulino, 22 jun. 1924 , n. 45 , p. 2

${ }^{218}$ Sobre Lino Guedes, ver MIRANDA, Rodrigo. Um caminho de suor e letras...op.cit., pp.66-72 e BERND, Zilá. Poesia Negra Brasileira. Porto Alegre: Editora AGE, 1992.

${ }^{219}$ Negritude (Négritude em francês) foi o nome dado a uma corrente literária que agregou escritores negros francófonos e também uma ideologia de valorização da cultura negra em países africanos ou com populações afro-descendentes expressivas que foram vítimas da opressão colonialista. Para saber mais sobre Negritude, ver BERND, Zilá. O que é negritude. São Paulo: Brasiliense, 1988.
} 
Ao lado de Guedes estava o poeta negro Gervásio de Moraes, ocupando o cargo de redator-assistente, tendo colaborado com o jornal através de artigos e poemas de sua autoria. Era conhecido como contador de malungo, o que significava no contexto da época ser um contador de histórias sobre os amigos e suas experiências de sofrimento. Gervásio de Moraes permaneceu no jornal Getulino até sua mudança para São Paulo juntamente com Lino Guedes e Benedito Florêncio, onde continuou sua militância através de outros jornais e ajudou a fundar em 1926 o Centro Cívico Palmares. Faleceu em 13 de janeiro de 1945.

Outra figura importante desse tempo na imprensa negra, e vinculado principalmento ao Getulino e à atuação na imprensa tradicional de Campinas, era Benedito Florêncio. Foi seu o editorial de lançamento do jornal, assim como eram seus os artigos e notas mais ácidos do periódico negro. Florêncio tinha uma longa experiência em outros jornais da imprensa campineira, com uma coluna no Diário do Povo, intitulada Tome Nota, onde assinava com o pseudônimo de Machadinho e criticava abertamente a sociedade campineira, seus costumes e ações, com caráter moralista. Fechava sempre a coluna com a expressão latina ridendo castigat mores.

Benedito Florêncio também foi tesoureiro da Federação Paulista dos Homens de Cor,e ao lado de Lino Guedes, membro do Clube Literário de Culto à Ciência, o qual reunia intelectuais influentes de Campinas como o bispo D. João Nery, Coelho Neto e Benedito Otávio. Após o fechamento do Getulino, demitiu-se do Diário do Povo e, como já foi dito, seguiu com Guedes para São Paulo, onde trabalhou em outros jornais, sem nunca ter deixado de enviar sua coluna para o jornal campineiro.

O Getulino foi objeto da atenção de outros periódicos, como o Diário do Povo, por exemplo, da mesma cidade, que assim comentou o aparecimento e a atuação de seus redatores:

Temos sobre a mesa o n.1 do "Getulino", novo semanario que acaba de apparecer nesta cidade, e dedicado á defesa dos homens de côr.

É composto em officinas próprias, onde em breve será também impresso, trás na sua primeira página um bom retrato do grande Luiz Gama (Getulino), notavel jornalista, advogado, o polemista de pulso, que tanto honrou a raça negra no Brasil.

É redator-chefe do citado semanario, Lino Guedes, moço de côr dos mais esforçados, e nosso prezado companheiro, a quem deve a classe assignalados serviços.

Como secretario de redacção está Gervasio de Moraes, que bons versos já tem escripto e que é uma esperança promissora de sua raça.

São directores proprietarios os srs. Martinho Andrade e Alcino Moraes, dois elementos que optimos serviços têm prestado á gente de sua raça.

O "Getulino" tem o seu primeiro numero todo collaborado por homens de côr, excepto um artigo, trazendo bons trabalhos, merecendo mesmo destaque o soneto de Augusto Marques. 
Ao novel collega desejamos vida longa e prospera. ${ }^{220}$

Parece-nos que a sistemática ênfase do referido periódico da imprensa tradicional no fato de que o novo jornal era feito por e para "homens de cor" e "gente de sua raça" não incomodava os redatores do Getulino, que até a viam como fato positivo pela aceitação que o número inicial teve na cidade.

Quanto à formatação, as páginas do Getulino eram feitas de papel-jornal, em função de seu menor custo, principalmente para a publicação em grandes quantidades. No cabeçalho, o título se apresenta em letras maiores, produzindo efeito imediato, com o subtítulo Orgam para a defesa dos interesses dos homens pretos.

Logo nas primeiras colunas, trazia ao público as matérias mais importantes, entre as quais as que se referiam aos debates em torno de questões urgentes para a população negra de Campinas. Muitas vezes o tom era moralizador, assim como a temática em torno da questão das "raças" gerava uma série de discussões posteriormente no meio negro. Tornou-se famoso, por exemplo, um folhetim intitulado A Boa Severina, o qual apareceu na segunda edição, prolongando-se até o número 54 , e totalizando 48 episódios ${ }^{221}$

Havia espaço para críticas e sugestões dos leitores, poesias de algum literato negro, contos que traziam na maioria das vezes relatos sobre amores não correspondidos ou idealizados e até concursos de beleza. A vida social e esportiva marcava presença na segunda página.

As duas últimas folhas continham anúncios de vários empresas e produtos. Os principais anunciantes eram barbearias, lavanderias, estacionamentos, quitandas, farmácias, funerárias e lojas de calçados. Os endereços mais frequentes nos anúncios eram a Rua 13 de Maio, a Rua José Paulino, a Rua Barão de Jaguara e a Rua Regente Feijó.

Porém, em algumas oportunidades a quantidade de anunciantes era muito grande e mais páginas eram necessárias. No número 2, somente a primeira de quatro páginas foi reservada ao editorial e notícias mais importantes, sendo as demais utilizadas para a publicidade. Ao todo, quarenta anúncios foram veiculados, sendo vinte e dois na segunda página, dezoito na terceira e apenas a Casa Di Lascio na última, em propaganda de folha inteira.

O Getulino foi um periódico de publicação consideravelmente estável se comparado com seus pares da imprensa negra: sua primeira fase ocorreu entre julho de 1923 e dezembro

${ }^{220}$ Artigo de Álvaro Ribeiro em Diário do Povo, transcrito em Getulino, 5 de agosto de 1923, n.2, p1. Grifo nosso.

${ }^{221}$ Ver CHALHOUB, Sidney, Trabalho, Lar e Botequin, Campinas, UNICAMP, 2001, p.66 
de 1924, tendo apresentado 64 edições ininterruptas, algo raro para esse tipo de jornal. Em razão de dificuldades financeiras (outro fator inegavelmente comum a essa imprensa), o jornal não circulou entre janeiro e início de maio de 1925, voltando apenas por ocasião de uma edição comemorativa ao 13 de maio. Houve a tentativa de renascer em São Paulo em 1926, mas frustrou-se.

Do ponto de vista de estrutura financeira, o jornal foi criado com uma razoável capitalização, segundo as fontes pesquisadas. Estima-se que os empreendedores Alcino de Moraes e os irmãos Andrade empenharam cerca de 500 mil cada no capital inicial. Martinho e Christino Andrade eram chauffeures, condutores de veículos para transporte de passageiros mediante pagamento, e ambos trabalhavam no mesmo ponto, o largo da estação de trem da Companhia Paulista.

De acordo com nota do próprio Getulino, Alcino Moraes aplicou $500 \$ 000$ no jornal:

\begin{abstract}
Os irmãos Andrade, proprietários da empreza "Getulino" pela presente declaram que pagaram ao sr. Alcino de Moraes, a quantia de 500\$000, correspondente ao capital que este sr. Dispendeu na empreza, tendo o mesmo sr. Alcino Moraes desistido de receber $447 \$ 000$ de lucro a que tinha direito pelos rendimentos verificados até esta data. A empreza continua assim na mais franca prosperidade e harmonia, tendo sido tudo liquidado amigavelmente. ${ }^{222}$
\end{abstract}

Por motivos não esclarecidos pelas fontes, um dos sócios resolveu retirar-se ou foi retirado da sociedade, tendo os sócios remanescentes realizado um acordo de compensação entre sua participação societária e os lucros aferidos em pouco tempo de existência do jornal (cerca de três meses). Pressupõe-se que a participação inicial era igual para os três sócios.

Mesmo assim, a redação do jornal era realizada na residência de Martinho Andrade. O fato do jornal ter publicado 64 edições de forma ininterrupta em seus primeiros dezoito meses pode ser um reflexo da estável situação financeira ${ }^{223}$. Quanto ao preço, o exemplar avulso custava \$200, o mesmo valor cobrado por seus pares à época (O Clarim da Alvorada e $\mathrm{O}$ Kosmos), bem como por jornais da imprensa tradicional, como por exemplo, O Estado de São Paulo. Porém, as assinaturas variavam significativamente:

\footnotetext{
${ }^{222}$ Getulino, 28 out. 1923 , n. 14 , p. 3

${ }^{223}$ O jornal deixou de circular, em sua primeira fase, apenas no mês de julho de 1924, por ocasião da Revolução Tenentista, conforme nota do Getulino em 24 de agosto de 1924, n. 50, p.3.
} 


$\begin{array}{llcl}\text { Valores em réis } & \text { Assinatura anual } & \text { Assinatura Semestral } & \text { Periodicidade } \\ \text { O Estado de São Paulo } & 40 \$ 000 & 22 \$ 000 & \text { diária } \\ \text { O Clarim da Alvorada } & 5 \$ 000 & 3 \$ 000 & \text { mensal } \\ \text { O Kosmos } & 5 \$ 000 & 3 \$ 000 & \text { mensal } \\ \text { O Getulino } & 12 \$ 000 & 7 \$ 000 & \text { semanal }\end{array}$

Assim como a venda de exemplares avulsos, a quantidade de anúncios publicitários era fonte significativa de receita para os jornais, chegando algumas vezes a superar aquela obtida com o volume de assinaturas e leitores regulares. ${ }^{224}$ Era possível notar que os jornais da grande imprensa atuavam de forma semelhante a uma empresa comercial, no sentido de terem em vista também a obtenção de algum lucro, enquanto os jornais negros mantinham-se precariamente, pois moviam-se por idealismo ao fazer parte de um processo de educação e integração da população negra. ${ }^{225}$

No entanto, encontrar anunciantes não era tarefa fácil, e se aliada à inadimplência dos assinantes, colocava o jornal em sérias dificuldades financeiras, dependendo em demasia do valor das assinaturas. A estratégia era, então, buscar diversificar os assinantes entre ramos de atuação (medicamentos, cigarros, roupas, livros, lojas e profissionais liberais), escolhidos nas empresas mais tradicionais da região, a fim de evitar falta de pagamento.

Martinho de Andrade também era fundador do Grêmio Dramático Luiz Gama, uma associação recreativa que promovia bailes para a população negra de Campinas. Isso favorecia uma maior distribuição e penetração do jornal, pois o público que frequentava esses eventos possuía uma condição financeira acima da média, já que conseguia arcar com despesas relacionadas à cultura e lazer.

Exatamente pela escassez de recursos, o tom da cobrança junto aos devedores era austero, e frequentemente sua exposição pública era usada como estratégia para "sensibilizar" o mau pagador:

\footnotetext{
Avisamos aos nosso bondosos assignantes, que somos obrigados, não só, suspender a remessa de nossa folha, a todo aquelles que estão com mais de três meses de atraso; e, assim sendo, constrangidamente, publicamos também, os seus nomes. ${ }^{226}$
}

Como qualquer outra empresa ou entidade que necessita manter-se com recursos próprios e de terceiros, há que promover um equilíbrio entre receitas e despesas. No caso

\footnotetext{
${ }^{224}$ GALVÃO, Walnice Nogueira. No calor da hora: a guerra de Canudos nos jornais, p.2 apud SCHWARCZ, Lilian. Retrato em branco e preto: jornais, escravos e cidadãos em São Paulo no final do século XIX. São Paulo, Companhia das Letras, 1987, p. 64

${ }^{225}$ PINTO, Regina Pahim, op. cit., p.64.

${ }^{226}$ Getulino, 6 jan. 1924, n. 24.
} 
desses jornais, que não eram mantidos por capitalistas, representantes da elite ou apoiados pela grande imprensa, as fontes de recursos provinham das vendas de jornais, assinaturas, bailes, anúncios e doações. Em contrapartida, o periódico e seus mantenedores (na grande maioria das vezes, seus próprios redatores e funcionários) tinham que arcar com elevado e crescente preço do papel, aumento do custo de mão de obra e frequente inadimplência. Qualquer desequilíbrio nessa equação significava apenas uma coisa: o jornal não iria sair.

Em agosto de 1924, um aviso na primeira página, logo abaixo do cabeçalho, conclamava os assinantes a cumprirem suas obrigações para com a continuidade da distribuição;

\footnotetext{
Avisamos aos nossos assignantes nao so da Capital como de todo o interior, que estamos procedendo a cobrança de nossa folha. Todos os assignantes acima referido devem até o dia $1^{\circ}$ de Outubro, reformar as suas assignaturas com os srs. Correspondentes, pagando pelo menos um semestre adiantado ou então, remetter as importancias em vale postal aos IRMÃOS ANDRADE A RUA LUSITANA 135. Caso contrario suspenderemos a remessa do nosso jornal. ${ }^{227}$
}

Mesmo assim, o Getulino apresentou uma estabilidade fora com comum para jornais criados e publicados na década de 1920. Sua tiragem era considerada razoável, sendo estimada em 1.500 exemplares mensalmente. ${ }^{228}$

Pela grande quantidade de anúncios veiculada pelo periódico campineiro (chegou a apresentar 23 anunciantes em sua segunda publicação, sendo que a média dos jornais da imprensa paulistana era de 10 anúncios naquela época), se imagina que essa fonte de receitas era estratégica para a continuidade do jornal.

Em agosto do ano seguinte ao de sua fundação, a situação financeira parece ter deteriorado ainda mais, em decorrência dos elevados preços do papel e do custo da mão de obra (pessoal envolvido na impressão e distribuição):

Devido a enorme alta do papel e da mão-de-obra a acontar do dia $1^{\circ}$ de agosto do proximo mes, a nossa folha será destribuida em Campinas pelos preços seguintes: Anno $12 \$ 000$, Semestre, $7 \$ 000$, Mez $1 \$ 500$ e numero avulso $\$ 300$, e no interior: Anno $15 \$ 000$, semestre $8 \$ 000$ e Mez 2\$000). ${ }^{29,}$

${ }^{227}$ Getulino, 24 ago. 1924, n. 50, p.1

${ }^{228}$ Idem, ibidem, p. 3

${ }^{229}$ Idem, ibidem, p. 1 
O preço do exemplar foi então majorado em $50 \%$ e a assinatura anual, em $25 \%$. Tal medida visava a equilibrar as contas da entidade, bem como cobrir eventuais perdas com a inadimplência e diminuição no número de anunciantes.

Em relação ao discurso do jornal propriamente dito, a premissa mais frequente era de que "o maior inimigo do preto é o próprio preto", uma concepção que será acompanhada por alguns dos mais renomados exemplares da imprensa negra paulistana, como O Clarim da Alvorada, o Progresso e A Voz da Raça, que foi o veículo oficial da Frente Negra Brasileira. Com maior ou menor intensidade, a despeito da postura e da abordagem utilizadas, a maioria dos jornais que se seguiram ao periódico negro de Campinas terminaram por beber em sua fonte. Daí mais uma vez a oportunidade de ressaltarmos a importância de nossa proposta de recorte temporal em relação a esse período da imprensa negra paulista.

Uma das principais preocupações do Getulino era não transformar o preconceito em um álibi para justificar a exclusão do negro pura e simplesmente, como uma desculpa para seu fracasso e suas decepções. Para os redatores, o negro frequentemente se auto-excluía, como quando não entrava no jardim das praças e, ao contrário, o circundava.

\footnotetext{
Muita gente não gostou de falarmos do velho costume de passeiarem por fóra do jardim Carlos Gomes. Mas que fazer? Infelizmente dissemos uma verdade.

E, hoje mui constrangidos somos obrigados a apontar aos nosso patricios, desnecessario será dizer que nos referimos aos homens de cor, mais uma vesguice habitual, que é elles se collocarem á frente das procissões, a modos de mamãe óle eu.

Esse exhibicionismo do ultimo fato e de mais uma novidade parisiense, demonstra falta de educação religiosa, o que não nos recomenda bem.

Não queremos dizer com isto que fiquem na valla comum, atrás do pallio, comendo pó e sentindo todos os cheiros; que cerquem-na de esquina em esquina, mas andar na frente...jamais. ${ }^{230}$
}

O caso acima refere-se à convenção estabelecida entre brancos e negros, onde havia uma separação tácita dos espaços ocupados nesses locais. Nenhum preceito legal os obrigava a estarem separados, mas o negro não se mobilizava para mudar essa situação. Um ano depois, o fato do jornal tê-la denunciado e dos moradores e transeuntes conseguirem sucesso permite imaginar que os artigos do Getulino tinham boa circulação entre a população negra da cidade $^{231}$.

\footnotetext{
${ }^{230}$ Getulino, 5 ago. 1923, n.2, p.1. Grifos do autor.

231 "Folgamos, pois em dizer que graças a nossa eficaz acção em um anno, não é mais notada aquella odiosa separação que havia na ampla platéa do Colyseu; e que está consideravelmente reduzido o numero de pessoas que tinha o pessimo costume quase obrigação de passearem na parte externa do jardim da Praça Carlos Gomes" IN: Getulino, 24 ago. 1924, n. 50, p.1
} 
A denúncia contra o preconceito era também assunto frequente. Já nos referimos a quão crítica era a situação dos operários e negros em São Paulo, muitos dos quais obrigados a viver em cortiços e porões, sem condições higiênicas mínimas. Em Campinas, a situação não era diferente, como lembra o jornal:

Cremos que a intenção da autoridade não é melhorar quem quer que seja quando se trata de estabelecer a ordem...

Mas...segundo o noticiario dos jornaes, parece que, unicamente por ellas ser pretas, morar em cortiço e não ter occupação (o que não é verdade) é que lhes movem guerra. $^{232}$

Nesse caso, o jornal contestava a ação da Força Pública campineira, que realizava batidas nos cortiços, e revelava discriminação contra mulheres negras, visivelmente relacionando sua cor à condição social e habitação.

Isso é reflexo do discurso higienista então vigente, também apoiado por interesses de empreendedores imobiliários interessados na ocupação de áreas centrais nas cidades.

Além disso, revelava outra face do preconceito, uma vez que acusavam-nas de desocupadas, e, no entanto, faltavam braços para o serviço doméstico, pois as famílias "preferiam brancas" nesse tipo de trabalho:

O bonito em tudo isso, é em affirmar-se que o resultado da campanha policial, "será de beneficio para as donas de casas, que luctam com falta de empregadas", esquecendo-se de passar uma olhadela para os pequenos annuncios dos jornaes, onde, não raro encontramos: "Precisa-se de empregada à rua tal, numero tanto. Prefere-se branca"233

Em Campinas como em São Paulo, a prática do "prefere-se branco" foi substituída com o passar do tempo pelo "exige-se boa aparência" dos anúncios de emprego, frase que exige comentários a serem feitos mais à frente.

Tão frequente quanto a denúncia do preconceito racial era a imputabilidade da culpa aos próprios negros por esse estado de coisas:

Mas, infelizmente, os nossos irmãos em côr descuram criminosamente destas coisas pois conhecem melhor a história pugilista de um Harry Willis, nos Estados Unidos, ou a situação detalhada de um campeonato varzeano na capital, do que as necessidades prementes da nossa defeza racial. ${ }^{234}$

A forma incisiva e direta dos articulistas em chamar a atenção de seus patrícios era também reflexo da rudeza com que foram tratados os escravos da região em um passado 
escravista recente. Campinas era conhecida como a "Bastilha Negra" ou "purgatório dos negros". Muitos contos sobre a escravidão traziam consigo uma parte dessa representação:

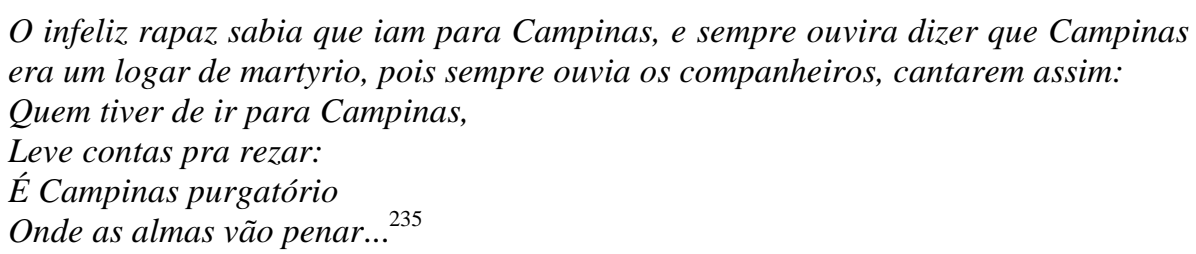

Outro tipo de discurso frequente no Getulino era o da integração à sociedade brasileira, valorizando o papel do negro como protagonista da história. Essa abordagem, longe do caráter conformista, seria utilizada como propaganda e apelo junto à população negra, inclusive por reconhecidas organizações, como a Frente Negra Brasileira:

Nós hoje, homens livres, devemos enfrentar todas as difficuldades que por ventura encontramos em nossa vida, sempre com resignação, recordando dos nossos antepassados, que, por nossa causa atravessaram batalhas ferrenhas conquistando um dia a inesquecível victória. ${ }^{236}$

O negro é, portanto, responsável por advogar sua própria causa. Mas para isso, ele também busca ser aceito na sociedade dominante, e procura implementar isso através da expressão de seu sentimento patriótico.

O Brasil não é filho do extrangeiro, não é tão pouco só o branco nacional que, si existe com as modalidades actuaes, é porque o preto o amamentou, o embalou, e com inaudito esforço arroteou os campos, desbravou florestas e formou fazendas,

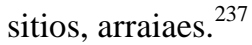

A fusão das raças (...) a condição primordial da nacionalidade (...)

Contrariar este ideal é falta de patriotismo; ferir e desmanchar esse anceio do pais, é impedir a evolução formativa da nacionalidade, é crime, é perversidade, que só a ignorância em cousas da pátria, póde produzir. ${ }^{238}$

Os editoriais dos jornais oscilavam entre atribuir a culpa da exclusão dos negros a eles próprios e buscar explicações para a situação de penúria e pauperização pela qual passavam:

Somos viciados, somos incultos, somos atrasados e analphabetos?

A culpa não é nossa: interrogae os quatrocentos annos de nosso ferrenho captiveiro, interrogae o miserável regimen de obscurantismo em que fomos creados, interrogae a lei do atavismo e da hereditariedade.

O nosso livro foi o chicote e a nossa escola foi a senzala. ${ }^{239}$

Como em todos os jornais da Imprensa Negra, a educação e o trabalho foram temas dos mais importantes a serem abordados. Lino Guedes chama a atenção para a valorização da

\footnotetext{
${ }^{235}$ Getulino, 23 dez. 1923, n. 22, p.1

${ }^{236}$ Getulino, 14 set. 1924 , n. 52, p.1

${ }^{237}$ Getulino, 2 mar. 1924, n. 32, p. 1

${ }^{238}$ Idem, ibdem

${ }^{239}$ Getulino, 28 set. 1924 , n. 54, p.2
} 
juventude negra, através da educação e do exemplo a ser seguido por São Paulo, que já havia "cumprido o seu papel” quanto à educação fundamental. As reivindicações são feitas diretamente às autoridades da época:

Coube a S. Paulo a primazia de tornar obrigatório o ensino primario, obtendo, durante o anno de 1923, na maioria das escolas onde ministra esse ensino, frequência correspondente a mais de $90 \%$ dos alumnos matriculados. (...)

Póde-se, portanto, considerar resolvido, em S. Paulo, o mais sério dos nossos problemas nacionaes - o da instrucção elementar do nosso povo. (...)

Nenhum democrata consciente poderia admittir a existencia de uma república moderna contendo o número de analphabetos que a nossa Estatística revela. Só se explica o descaso pelo assumpto, por parte de milhões dos nossos estadistas, considerando que lhes convem a ignorancia do povo, com a qual contam para os seus actos de usurpação e espoliação. (...)

Por outro lado, conviria compenetrarem-se as classes dirigentes da obrigação que tem o Estado de assegurar a instrucção da juventude. ${ }^{240}$

A mulher negra assume papel significativo na vida urbana e é o sustentáculo da família, uma vez que possui mais chances de conseguir ocupação em serviços domésticos, como os de lavadeira ou cozinheira. Por isso, a ênfase na educação profissionalizante é colocada sobre as meninas:

As vossas filhas, nunca devem arrendar de seus lares, sob o pretexto de que vão trabalhar para vestirem-se e comer...

Lavar, engomar, bordar, costurar, e mesmo fazer doces em casa, por hypothese, não dá para finas iguarias e ricos e caros vestidos?

Esse rebento mimoso de vossa existência, que a educação actual chama de melindrosa, é flor da sombra que jamais deve sahir da estufa, pobre embora, mas honesta de vossa casinha onde reine o trabalho. ${ }^{241}$

Os redatores do Getulino conhecem os riscos a que estão submetidas as moças negras, por ocasião dos bailes assim como o das condições a que estão expostas nos cortiços. Conhecem ainda muito bem o preconceito existente na sociedade campineira e paulista em geral. Em que pese o tom machista do discurso, o pragmatismo visa retirar a mulher negra da situação de marginalização:

Fora de casa, as moças são discriminadas, de maneira similar, aos homens:

Precisamos, na defesa dos brasileiros pretos, registrar um facto, injurioso ás moças de cor (...) Injusto é prohibir-se que as mãos das moças pretas sejam recusadas para os serviços da fiação ou da tecelagem da materia prima (...) Ás moças de cor aconselharemos que, - de fórma alguma - não penetrem nos humbraes do rico estabelecimento, em busca de emprego, pois melhor lhes será trabalhar em outros, não menos honrados, mistéres. (...) ${ }^{242}$

A última edição regular do jornal em Campinas, em dezembro de 1924, parece selar de vez o período mais significativo da imprensa negra naquela cidade, devido aos problemas

\footnotetext{
${ }^{240}$ Getulino, 2 mar. 1924, n. 32, p.1

${ }^{241}$ Getulino, 6 abr. 1924, n. 37, p.1

${ }^{242}$ Getulino, 9 set. 1923 , n. 7, p. 1
} 
financeiros. Entretanto, outras questões também estavam envolvidas no fechamento do jornal, entre elas, a postura da comunidade à qual era dedicado, em relação ao discurso firme e puritano expresso nos editoriais.

Agora, como que pondo uma nota triste no conjuncto que se vos afigura alegre, num arranco de dôr pesada e omára vos digo que todas aquelas ideias bôas, sãs, nobres abortaram. (...)

É incalculável o pouco causo (sic), com que os homens pretos de Campinas, recebem o Getulino. Envergonham-se em ler o orgam que defende os seus interesses, negando as vêses a sua raça infeliz que trabalhava ao zunir constante do chicote. (...) ${ }^{243}$

Em 1926, Lino Guedes mudou-se para São Paulo, como já foi dito, acompanhado por Benedito Florêncio e Gervásio de Moraes, mas manteve o nome Getulino para o jornal, que voltaria a circular apenas em uma edição comemorativa.

Após hiato de um ano, lançaram uma edição em 13 de maio, com as inscrições "segunda phase" do lado direito, acima do título, "anno 3" e "número 1" no cabeçalho. Estavam provisoriamente na Avenida São João n. 271 e toda correspondência, com ou sem valores, deveria ser entregue aos cuidados de Lino Guedes ${ }^{244}$, com a assinatura anual fixada em $15 \$ 000$ réis. O número avulso custava \$200.

Em artigo na primeira página intitulado "Trêse (sic) de Maio e alguns dos seus obreiros", o colaborador Guêldêsnio Pinto descreve o processo abolicionista e homenageia seus artífices. O jornal espalhou fotos de Luiz Gama, Princesa Isabel, Antonio Bento e José do Patrocínio pelas quatro páginas com a legenda "Sombras que vivem", mas não fez comentários específicos a respeito deles.

Em uma pequena nota, o editorial atenta para o preconceito dos argentinos contra os brasileiros:

\footnotetext{
"Macaquitos brancos", nos chamam os nosso irmãos do Prata. Com razão? Talvez.

Cá entre nós, sem que ninguém nos ouça, porém. Gostamos de imitar tudo que nos vem d'alem mar...Adoptamos geralmente o que não presta. O que não nos convem. Ao nosso costume. Ao nosso clima. A nossa religião.

Sem olhar para o ridículo desta ou daquella moda, uamol-a. Prevendo o seu sucesso $^{245}$.
}

Uma parte significativa da primeira página foi ocupada com a aprovação da construção de um monumento à "Mãe Preta" pelo presidente Washington Luis, que enviou resposta a Vicente Ferreira, então militante de associações negras no Rio de Janeiro:

\footnotetext{
${ }^{243}$ Getulino, 20 dez. 1924, n. 64, p. 1.

${ }^{244}$ Getulino, 13 mai. 1926, anno 3, n. 1, p.2

${ }^{245}$ Idem, ibidem, p. 1
} 


\section{Ilmo. Sr. Vicente Ferreira}

Ao regressar do Rio, encontro aqui sua carta de 6 do corrente, em que pede o meu modo de sentir sobre a iniciativa tomada por Candido Campos, brilhante director da "A Noticia", para um monumento á Mãe Preta.

Para responder sinceramente não preciso repetir proposições do meu programma de governo ahi lido em dezembro passado., reaffirmando que a realização de tal monumento será mais uma demonstração de fraternidade.

"A fraternidade, sentimento que une a todos os homens como irmãos, sem dúvida alguma, será a obra dos povos sul-americanos".

E porque entre nós não ha superstições de raças, preconceitos de cores ou exclusivismo de origem, na America do Sul o Brasil é o paiz fadado para a realização da fraternidade.

Na obra do progresso moral e material que estamos realizando vê-se bem que não se contam differenças de raças. No mundo só valem os climas e estes são modificados pelo trabalho dos homens.

Subscrevo-me com estima e consideração. Patricio grato(a) Washington Luis ${ }^{246}$.

A carta acima já havia sido transcrita no jornal A Noticia de 23 de abril de 1926, e reflete o desejo de erigir um monumento à Mãe Preta nos mesmos moldes do proposto pelas Daughters of the American Confederacy (filhas dos confederados norte-americanos) cerca de três anos antes, cuja pretensão era uma estátua para Mammy na capital americana. No entanto, ao contrário da reação de grupos afro-americanos, que repudiaram a ideia, os afro-brasileiros aderiram à iniciativa de Cândido de Campos ${ }^{247}$.

Pode-se notar claramente na mensagem do então presidente, alguns vestígios da propalada democracia racial no Brasil, onde o preconceito e a discriminação de cores não existiriam.

Os redatores do Getulino aproveitam a oportunidade para criticar o "modelo" americano no tratamento dado aos negros:

E, deste modo, enquanto os homens norte-americanos, ignorantes do terrivel phenomeno que haviam de legar aos posteros com os seus preconceitos ethnographicos, insularam-se, deixando que em sua patria evoluissem duas raças oppostas, uma espesinhada, outra espesinhante, nós, os latinos de côr, realizávamos a mais empolgante obra fraternal de todos os tempos: a comunhão dos três differentes elementos raçaes (sic) que uma vez se encontraram na noite dos nossos tempos...

E a prova está ahi, patente, insophismavel, no movimento de erecção de uma estátua, á "mãe preta" da nossa infancia e da infancia da nossa patria. (... $)^{248}$

\footnotetext{
${ }^{246}$ Getulino, 13 maio 1926, anno 3, n.1, p.1

247 A figura da Mãe Preta é tema de várias reportagens dos jornais negros, tanto nas comemorações do 13 de maio como nas edições próximas a 28 de setembro, quando a mesma é homenageada. Para saber mais a respeito da Mãe Preta, ver ensaio de Micol Siegel, Mães Pretas, filhos cidadãos. IN: CUNHA, Olivia Maria Gomes e GOMES, Flávio dos Santos. Quase-cidadão: histórias e antropologias da pós-emancipação do Brasil. Rio de Janeiro: FGV editora, 2007, pp.315-346.

${ }^{248}$ Getulino, 13 maio 1926, anno 3, n.1, p.1
} 
Em outro trecho, o "americanismo" e as suas influências são mais uma vez duramente atacados:

\begin{abstract}
Nós, porém, não somos o "país da liberadade", nem tão pouco temos em nosso porto principal, como um panno de bocca berrante, uma imensa e pharaonica estatua da Liberdade, muito embora haja sido em nossa terra onde primeiro se arregimentaram e se uniram para a vida e para a morte, os primeiros homens livres do continente.

Não tendo nada disto, nos resta apenas comprazer-nos com a verdade de que se o americanismo tem, infelizmente, influido no nosso organismo social, alterando costumes e leis, delapidando crenças e tradições com os seus jazz-band estrambolicos, as suas miss futeis e cinematicas, com os seus heroes hypotheticos, com a sua "guerra muda" e com sua maldição klukluxklanica aos humildes, tanto não ha conseguido em nossa esphera intellectual, de onde dia a dia avultam individualidades como a de S. Excia. o Sr. Washington Luis, que saber ver no nosso gesto de respeito aos humildes, no monumento à Mãe Preta uma demonstração irrefutavel de fraternidade e de nobreza brasileira... ${ }^{249}$
\end{abstract}

Na segunda página desse mesmo número é feita uma homenagem aos irmãos Martinho e Christino José de Andrade e a Antonio Soares de Queiroz, militantes dos tempos do Getulino em Campinas. Ao final da nota, Lino Guedes critica a falta de união e as desavenças no meio negro:

\begin{abstract}
As lutas intestinas, as dissenções que se localizam no seio das agremiações, de programmas ôcos, salvo raras excepções, não adormentam o nosso entusiasmo, mais nos acalentam a esperança de um dia ver raiar a aurora da União - unico ponto que falta à emancipação completa dos escravizados de hontem : a emancipação moral. Grandes foram as nossas decepções até hoje, e certos estamos de que não pequenas serão as controversias que temos de abraçar. ${ }^{250}$
\end{abstract}

A terceira e quarta páginas praticamente se dedicam a contos, poesias, homenagens e a reedição de um concurso de beleza promovido pelo Getulino, agora em São Paulo:

Qual a mulher mais bella de São Paulo?

Como fizemos em a nossa primeira phase, abrimos com o presente um inquerito, afim de apontar qual a mulher mais bella da Capital.

Numerosa é a familia preta que aqui milita. Difícil seria entre senhoras e senhoritas, dizermos qual deve ostentar a palma da belleza...Os nossos leitores disso se incumbirão, enchendo o enviando à nossa redacção o cupom abaixo... ${ }^{251}$

Esse último exemplar, sem anúncios publicitários, revela uma situação bem diferente da de outrora, quando o Getulino chegou a abrigar cerca de quarenta deles: uma constatação sobre a importância de haver estabilidade financeira dos periódicos para a sua manutenção e continuidade, não só as dos negros, mas de qualquer outro.

Mesmo com ênfase no caráter comemorativo requerido por essa edição após uma longa ausência, Lino Guedes faz questão de ressaltar o programa do periódico e o sentido da luta do negro:

\footnotetext{
${ }^{249}$ Getulino, 13 maio 1926, anno 3, n.1, p.1

${ }^{250}$ Idem, ibidem, p. 2

${ }^{251}$ Idem, ibidem, p.4
} 
Depois de um interregno de alguns mêses, voltamos á lida, tornamos a labutar no terreno árido da imprensa em pról dos nossos irmãos que outr'ora soffreram as mais atrozes provações em nome da lei!

(...) Desnecessário será affirmármos que não nos afastaremos, uma linha siquer, do nosso porgrámma inicial: que seremos irreductiveis, implaveis, para os dectractores da relegada (?) Raça Negra, ao passo que emprestaremos mão forte a todos os que, á medida de suas forças, procurem exalta-la, dignifica-la, ennobrece-la ${ }^{252}$.

Assim terminava definitivamente a jornada do Getulino, que não conseguiu ir adiante do $1^{\circ}$ número na segunda fase, mas não a dos homens que se dedicaram a elevá-lo como um dos mais importantes periódicos negros da história brasileira. Gervásio de Moraes e Benedito Florêncio continuaram colaborando com outros jornais, assim como Lino Guedes, que revelou sua militância em São Paulo através do jornal Progresso, fundado por ele em 1928, como veremos mais adiante.

$$
* * *
$$

\section{Elite}

Dois anos antes do Getulino deixar de circular, ou seja, em 1924, surgiu o jornal Elite - Orgam Official do Grêmio Dramatico e Literário "Elite da Liberdade”.

Nesse ano, São Paulo revoltou-se contra o governo federal. Desde o início do século, a política governamental não agradava nem à classe média nem àquelas mais pobres. A recuperação com as perdas ocorridas após a Primeira Guerra e com a epidemia de gripe espanhola parecia acontecer, mas a indústria ainda enfrentava altos e baixos no nível de produção, retomando o desenvolvimento em 1922 e 1923, mas apresentando uma séria queda em 1924. O índice do custo de vida no Brasil havia dado um salto de mais de $40 \%$ apenas entre 1920 e $1924 .^{253}$

As práticas eleitorais eram permeadas das intenções de políticos com vistas a se perpetuarem no poder, as fraudes se sucediam e a década se caracterizou por rebeliões de militares de baixo escalão, especialmente tenentes. O conjunto de rebeliões tomou o nome na historiografia de tenentismo.

Como já foi dito, São Paulo se rebelou. A cidade parou e o comércio de alimentos, atingiu as populações mais pobres, entre elas os operários, cujo poder de compra era mínimo. A situação era descrita em conclamações ao povo e aos rebelados, como a que se segue:

\footnotetext{
${ }^{252}$ Getulino, 13 maio 1926, anno 3, n.1, p.3

${ }^{253}$ Ver FAUSTO, Boris. A Revolução de 1930: história e historiografia. Op. Cit., p. 125
} 
Tragédia em São Paulo. 1924.

[...] O presidente da Associação Comercial, Macedo Soares, pede para não atingirem os mercados de alimento. A cidade não suportaria por muito tempo a obstrução das vias de abastecimento dos mercados ${ }^{254}$.

[Os operários estavam] de pé descalço e alimentação parca (um punhado de farinha de mandioca, feijão, arroz, carne seca), artigos alimentares baratos e abundantes no mercado; café adoçado com mascavo e um pouco de farinha, pois pão era artigo de luxo, bem como o leite, a carne, os condimentos, os legumes (estes últimos desconhecidos na casa do trabalhador ${ }^{255}$.

O conflito durou 22 dias apenas e foi debelado, mas causou vários danos à cidade $\mathrm{e}$ expôs a fragilidade dos poderes públicos estaduais e municipais para lidar com esse tipo de situação. Indiscriminadamente, rebelados e tropas federais usaram artilharia contra objetivos militares e civis, levando a população ao pânico e à sua evasão acelerada da capital.

O jornal O Estado de São Paulo publicava, quatro dias após o início do conflito, uma nota que demonstrava o sentimento geral de perplexidade e o desconhecimento dos objetivos da revolta:

Há cinco dias que a população de São Paulo, completamente isolada do mundo, assiste perplexa a verdadeiros combates em vários bairros da capital, nos quais entram em ação o fuzil, a metralhadora e o canhão. Nada se pôde ainda apurar acerca das origens e dos fins do movimento militar que põe em justa inquietação toda a cidade. ${ }^{256}$

O senador paulista Alfredo Ellis foi mais além, em pronunciamento realizado no Senado Federal, na sessão de 11 de julho daquele mesmo ano: "é um ataque epilético o que a nação está presenciando". 257

Entre os muitos autores que trataram do tema, Antonio Risério também abordou o tema da revolução tenentista, considerando de especial importância as consequências desse momento, que posteriormente levaria à Revolução de 1930, e que ao mesmo mesmo influenciaria os "negromestiços no sentido da formulação de suas demandas":

Os tenentes pretendiam dar um jeito no país. Pôr um fim as desmandos e vícios do regime oligárquico. Era preciso moralizar e renovar o Brasil, pensavam, mesmo sem um senso claro da direção a seguir. Falava-se, ainda, da necessidade de liberdade de pensamento e imprensa. Um ideário, em suma, resumível em poucas palavras: combate à política oligárquica; defesa do nacionalismo, do industrialismo e da assistência social. (...) E era grande a simpatia popular pelo movimento. De outra parte, anarquistas, socialistas e comunistas se moviam com disposição, denunciando males sociais, defendendo a autonomia e a organização das classes trabalhadoras, promovendo greves e protestos públicos, produzindo jornais independentes. ${ }^{258}$

\footnotetext{
${ }^{254}$ DUARTE, Paulo. Agora nós! s/l., s/ ed., s/d, várias páginas apud DEACLETO, Marisa Midori. Comércio e vida urbana na cidade de São Paulo (1889-1930). São Paulo: Senac, 2002, p. 212.

255 DIAS, Everardo. História das lutas sociais do Brasil. São Paulo: Alfa-Omega, 1977, p.45, APUD DEACLETO, Marisa Midori. Comércio e vida urbana na cidade de São Paulo (1889-1930). São Paulo: Senac, 2002, p. 212.

${ }^{256}$ FAUSTO, Boris. apud A Revolução de 1930. Op. Cit., p.83

${ }^{257}$ Anais do Senado Federal, sessão de 11 jul. 1924, Rio de Janeiro, Imp. Nacional, 1927, p. 519

${ }^{258}$ RISÉRIO, Antonio. A utopia brasileira e os movimentos negros. São Paulo: Editora 34, 2007, p. 354.
} 
É dentro desse contexto que acreditamos haver forte influência dos demais movimentos, entre eles o operário, nas reivindicações sociais presentes nos jornais negros. Não por acaso, os mais consistentes nascem a partir daquele ano.

A imprensa operária denunciava o estado de pobreza extrema do trabalhador na cidade de São Paulo, reflexo da dura realidade de um centro que se industrializava e urbanizava rapidamente. Jornais de tendência anarquista, comunista e socialista, ao destacarem o trabalhador na capital como pobre e o desempregado como miserável, tinham em vista leválos à luta e à mobilização política, estimulando-os a assumir seu papel como sujeitos da História.

É possível pensar que essa postura dos jornais operários tenha incentivado as liderenças negras a seguirem caminho idêntico sobre reivindicações por melhores condições de trabalho, habitação e saúde. Mesmo significativamente excluído das melhores oportunidades, o negro não estaria totalmente alheio ao que se passava na Capital, principalmente em relação ao movimento operário e às condições precárias dos trabalhadores brancos.

Entre 1927 e 1934, por exemplo, o salário pago aos operários em São Paulo permaneceu relativamente estável, apesar da alta do custo de vida. Nesse período, o salário médio de um operário não especializado atingia $200 \$ 000$ mensais.

Em uma pesquisa realizada com 221 famílias operárias escolhidas aleatoriamente em bairros como Ipiranga, Cambuci e Bela Vista (onde o predomínio era de trabalhadores), verificou-se uma renda mensal de 320\$000, porém, esse valor refere-se a uma renda familiar.

Entre os operários, havia aqueles que trabalhavam como mensalistas ou por empreitada, portanto, o número de horas variava muito, e nem todas as empresas respeitavam as 8 horas diárias. A pesquisa apontava um salário "modal" para homens da ordem de 1 milréis por hora, equivalente a 8 mil-réis por dia. Supondo que o mesmo operário trabalhasse 25 dias por mês, receberia, em 1934, 200\$000 por mês. ${ }^{259}$

Para comparar, nos depoimentos prestados a Márcio Barbosa, escritor do Quilombhoje, Marcello Orlando, um militante da Frente Negra Brasileira, conseguiu entrar na Guarda Civil de São Paulo e o máximo que conseguiu ganhar foi $120 \$ 000$ mensais. Mesmo

\footnotetext{
${ }^{259}$ DAVIS, Horace. Padrão de vida dos operários na cidade de São Paulo. pp.113-66 IN: DECCA, Maria Auxiliadora Guzzo de. op. cit., p.21
} 
considerando o nível de qualificação requerido pela Força Pública, denota-se aqui a inferioridade no pagamento aos negros da cidade de São Paulo. ${ }^{260}$

O discurso e o programa da imprensa operária não eram homogêneos, devido às marcantes , o que os dividia. Comparando-a com a imprensa negra, é possível pensar que a existência de pontos em comum era maior entre as duas, exatamente porque a comunidade afro descendente não se agregou facilmente e não teve grupos maiores com viés político apoiando-a em suas reivindicações.

As condições sanitárias e de saúde também atingiam com maior frequência a população pobre, valendo dizer que a negra ainda estava mais exposta. Apesar da volta de epidemias como a de 1918 ser improvável, eram altos os índices de febre tifóide, desinteria, sarampo, lepra, meningite-cérebro-espinhal e tuberculose. Um problema como esse complicava ainda mais a saturada malha hospitalar da capital. Nos bairros operários era comum a falta de fiscalização, ausência de rede de esgotos e água encanada, e os poços eram construídos muito próximos às fossas. A contaminação era muito maior, e a mortalidade infantil, alta. Além disso, por falta de alimentação saudável e boas condições de habitação, o operário estava sujeito a doenças de "fundo eminentemente social", como a tuberculose.

Por tudo isso, uma das principais reivindicações no meio negro é a melhoria de condições para o acesso ao ensino público. Embora as dificuldades para um negro ir à escola fossem imensas, as lideranças insistiam no fato de que somente a instrução permitiria ao negro requerer seu merecido lugar na sociedade.

A imprensa negra, de certa forma, espelhou-se na atuação da imprensa operária nos anos 1920 e 1930 na cidade de São Paulo. O ponto comum é que ambas procuram estabelecer um contraponto às fontes ligadas ao poder, onde a dominação e o controle sociais são temas recorrentes. Os jornais de tendência anarquista, anarco-sindicalista, comunista, além dos de sindicatos, de pequenos grupos socialistas ou antifascistas faziam parte do cotidiano urbano e expressavam o ponto de vista dos trabalhadores, de como estes viam a cidade e seus problemas. Visavam, acima de tudo, arregimentação, mobilização, conscientização e denúncias.

Nos primeiros anos, as reivindicações mais prementes do movimento operário eram aquelas ligadas ao cumprimento da legislação trabalhista mínima e à melhoria salarial, além de condições dignas no ambiente de trabalho.

No caso do negro, as dificuldades em relação ao emprego eram muito maiores:

\footnotetext{
${ }^{260}$ BARBOSA, Márcio. Frente Negra Brasileira...op.cit., p.90.
} 
No largo São Bento havia uma agência de empregos, e estando desempregado fui lá para ver se arranjava um emprego para mim. Eu estava sentado lá no meio de todos os desempregados, quando apareceu um sujeito e disse pra o que estava ao meu lado: "Estou a procura de um, garçom que é para mim levar lá para o hotel". Então o camarada disse para ele; "Tem aquele rapazinho ali que entende bem do serviço de copa e cozinha, ele pode ser garçom". O camarada olhou e disse; "É mas eu tenho ordem de não levar preto".

Então eu comecei a perceber que a coisa estava assim e ninguém fazia nada, ninguém se movimentava, ia chegar a um ponto quando o negro não teria nem mais lugar para trabalhar, e já havia o subemprego, que utilizava negros na light, nas olarias, na sacaria, empurrando carrinho de armazém, etc., eram os serviços de negros. ${ }^{261}$

Ali entre a Rua Benjamin Constant até a Rua Quinze de Novembro se formavam grupinhos de negros contando as aflições, as desilusões, as barreiras, era um muro de lamentações. Mas também outros vinham contando: Tem um negro que pegou um emprego bom, ou que tem um negro que se formou doutor, o que era coisa rara. Só para entrar na escola já era uma dificuldade tremenda. Então se contava isso tudo no sentido de mostrar as capacidades negras que eram negadas pelo branco, porque eles diziam que o negro não tinha capacidade para coisa nenhuma. Era só aquela coisa de ser marginal, de ter que fazer os serviços deprimentes, que ninguém queria. E então os negros não aceitavam estas colocações que os brancos faziam, porque todos tinham consciência das suas capacidades, só não existiam as oportunidades para fazê-las. $^{262}$

Em ambos os casos, temos uma exclusão apriorística do negro quanto às oportunidades de emprego. Lojas como Sears e Mappin eram proibidas de contratá-los, mesmo que tivessem capacitação igual ou superior às de outros candidatos. $\mathrm{O}$ trecho abaixo, extraído do jornal Progresso, exemplifica bem a situação do negro que buscava emprego em São Paulo no ano em que aconteceu o crash da Bolsa de Nova York:

\footnotetext{
"Prefere-se branco"

A observação que se vê nos anúncios cria uma onda de desocupados.

Entre os sem trabalho, avulta os número de pretos. Aptos são para todo e qualquer serviço, corteses e educados, como a maioria dos escravizados de ontem. E, no entanto, vêem-se na contingência de passar por vagabundos.

Negam-lhes trabalho.

Assistindo ao exercício dos "grilos", onde é grande o número de negros, estava no viaduto Santa Ifigênia um apolíneo:

- Olá, "patrício", está gostando da coisa?

- Que remédio, irmão. Enquanto não encontra trabalho, "mata-se" o tempo assim...

- Que é isso! Não fale essas coisas na cidade dinâmica que é São Paulo.

- É uma verdade. Trabalho não falta. Mas não nos dão. Essa nossa cor...

- Não o entendo. Que tem a cor com o serviço...

- Espere (desdobrando um jornal vespertino, disse-nos). Leia essas coisas. "PRECISA-SE de um choffer, para carro de câmbio, à rua tal, número tal. Prefere-se branco. $^{263}$
}

\footnotetext{
${ }^{261}$ Depoimento de Henrique Antunes Cunha, militante negro APUD Motta, Ubirajara Damaceno da. Jornegro: um projeto de comunicação afro-brasileira. São Paulo - 1978. Dissertação de Mestrado em Jornalismo - Instituto Metodista de Ensino Superior. São Bernardo do Campo, 1986, p. 48

${ }^{262}$ Idem, ibidem, , p. 53

${ }^{263}$ Progresso, 26 set. 1929, p. 5
} 
O estigma do vagabundo definitivamente não se aplicaria ao negro, pois é vultoso o número de anúncios de negros nos jornais da imprensa tradicional oferecendo seus serviços. ${ }^{264}$ Muitas vezes, se o negro está perambulando pelas ruas, o sintoma imediato não é a vadiagem, e sim o desemprego, pois o mesmo pode estar à procura de uma ocupação. ${ }^{265}$

É nesse panorama turbulento e excludente que apareceram outros jornais empenhados não só em proteger e agregar a população negra, promovendo sua elevação moral nos bailes e nas associações, mas também buscaram conscientizá-la para as lutas que viriam, como o acesso ao trabalho digno, à educação, à moradia e à saúde. O aspecto reivindicatório dos periódicos da imprensa negra cresce e se consolida na Capital.

Foi o caso do já mencionado Elite. Seu redator chefe era o já citado Frederico Baptista de Souza, conhecido colaborador de outros jornais, como $O$ Bandeirante e A Liberdade; o secretário era Abílio Rodrigues e Alfredo Eugenio da Silva, o presidente do grêmio; Olívio Cardoso era o gerente. Havia ainda diversos outros colaboradores.

O jornal era impresso na Typographia Paulista, localizada à Rua da Assembléa n. 5658 e sua redação ficava na Rua dos Estudantes n. 14. Uma assinatura anual custava 5\$000 réis, a semestral $3 \$ 000$ e o número avulso, \$200.

De acordo com depoimento de Pedro Paulo Barbosa, militante da Frente Negra Brasileira, tomado por Miriam Nicolau Ferrara, o Grêmio Dramático, Recreativo e Literário "Elite da Liberdade" era

(...) um grupo fechado, andavam sempre bem trajados, promoviam bailes, piqueniques e viagens. Seu diretor, Alfredo E. da Silva, era funcionário público da Secretaria da Fazenda do Estado. Para filiar-se ao grupo era necessário provar que era casado, chefe de família, com situação econômica estável"266

Das quatro páginas da edição de número 2 , três se dedicavam praticamente a contos, eventos sociais, notas de falecimento e fúnebres e um concurso de beleza. No entanto, alguns trechos nos chamaram a atenção por tratarem de temas de relativa importância política.

Na primeira página do mesmo número, o editorial intitulava-se " O Brasil de amanhã", e o assunto principal era a expectativa sobre a aprovação do projeto de construção do Cristo Redentor:

\footnotetext{
${ }^{264}$ DOMINGUES, Petrônio. Uma história não contada...op. cit., p. 110.

${ }^{265}$ Tal comportamento e situação do negro foi confirmada por José Correia Leite em suas memórias, visto que nunca conseguiu estabilidade em seus empregos até 1937, quando obteve um emprego na prefeitura.

${ }^{266}$ IN: FERRARA, Miriam, Depoimento pessoal, op. cit., p. 60
} 
Lá no alto do Corcovado será em breve erigido o maior monumento do mundo. A imagem do Redemptor, descortinando toda a amplidão do oceano que no horizonte parece estreitar-se preguiçosamente com a abobada celeste num amplexo de amor, será uma sentinella, e mais do que isso ainda: será o farol que ha de allumiar o caminho, ou melhor o "Porto Seguro", onde poderão aportar todos que quizerem cooperar comnosco para a prosperidade de nossa amada Patria. ${ }^{267}$

O texto é otimista em relação à situação do país e o Cristo representava a esperança de dias melhores. $\mathrm{O}$ articulista via o Brasil em uma situação confortável inclusive em relação a outras nações:

Terra abençoada, o Brasil, pelas excepcionalissimas condições que offerece ao exercicio de todas as iniciativas de trabalho e prosperidade, será, graças á sua posição invejavel, em futuro muito proximo uma potencia de primeira grandeza na America Latina.

Estas considerações vêm a proposito da situação de relativa paz e tranquillidade, por que vae atravessando a nação no momento actual, justamente numa epoca em que em quasi toda a parte a humanidade geme e soffre, vergada sob o peso de todas as adversidades. $^{268}$

Segundo o autor, a situação econômica do país era favorável ao crescimento comercial, agrícola e industrial, motivada pelo câmbio positivo:

Com a alta do cambio, que vae promissoramente de vento em popa, já se notam em toda a parte, no alto commercio e na lavoura, emfim, em todos os departamentos onde a actividade humana desdobra-se multiforme, surtos de novos e grandes emprehendimentos, indicios de que o anno que ora iniciamos será para nós um anno feliz. $^{269}$

Essas notícias contrariam o pensamento de Roger Bastide, para quem a imprensa negra "só trata de questões raciais e sociais, (...) só se interessa pela divulgação de fatos relativos à classe da gente de cor”, conforme já foi dito páginas atrás. Ainda em seu editorial, Elite comenta as ações do governo no sentido de restabelecer a ordem e por fim ao conflito no Rio Grande do $\mathrm{Sul}^{270}$ :

O governo por seu turno, bem inspirado no desejo de restituir a paz ao seio da familia brasileira, levanta logo no fim do anno que expirou, o estado de sitio, que ia tornando permanente; manda emissario de sua confiança ao Rio Grande do Sul negociar um accordo mediante o qual cesse a luta fratricida que ha um anno vem ensanguentando o solo de um dos maiores Estados da federação, e, consequentemente, entravando seu magnifico progresso e prosperidade. ${ }^{271}$

\footnotetext{
${ }^{267}$ Elite, 20 janeiro 1924, n. 2, p1.

${ }^{268}$ Idem, ibidem

${ }^{269}$ Idem, ibidem

${ }^{270}$ Entendemos tratar-se da Revolta dos Libertadores. Para saber mais, ver DONATO, Hernâni. Dicionário das Batalhas Brasileiras. Vol. 17 Estudos Brasileiros. São Paulo: Ibrasa, 1996.

${ }^{271}$ Elite, 20 jan. 1924, p. 1
} 
O periódico também enfatiza a visita de uma missão inglesa ao Brasil para avaliar nossa capacidade financeira, até mesmo pelo elevado volume de investimentos no país:

\begin{abstract}
Outro acontecimento de grande importancia é o da vinda ao Brasil de uma missão de financistas inglezes, de reputada fama, para estudar as nossas condições economicas e financeiras. Essa missão que aqui chegou logo em princípios do anno, e que actualmente São Paulo tem a honra de hospedar, já se manifestou acerca de nossas possibilidades, de modo altamente lisongeiro para nós.

E essas palavras merecem ser registradas, tanto mais por serem proferidas por uma missão composta de homens especialistas em materia de finanças, e tambem, pelo facto de ser a Inglaterra o paiz mais interessado pelo nosso progresso. Pois é sabido que é ella quem tem maior capital aqui empregado.

Em summa: tudo vae correndo as mil maravilhas. ${ }^{272}$
\end{abstract}

Em nossas pesquisas, tivemos acesso a apenas um exemplar do Elite, em janeiro de 1924, sendo sua revisão importante na medida que trouxe informações novas sobre as realidades paulista e brasileira da época.

\title{
O Clarim da Alvorada
}

Se o Getulino desempenhou o papel a que se propunha em Campinas, outro periódico ergueria sua bandeira de luta, agora na cidade de São Paulo. No início de 1924, a par do Elite, a Capital veria surgir um dos marcos da imprensa negra paulistana: O Clarim da Alvorada. Juntamente com a Frente Negra Brasileira, ambos são considerados até hoje como os maiores símbolos de resistência, lutas, reivindicações e denúncias em prol da comunidade negra. Deixemos que José Correia Leite, uma dos fundadores do jornal, fale sobre o início da sua trajetória:

Fui crescendo e conheci um rapaz chamado Jayme de Aguiar. Ele morava na Rua Rui Barbosa. Nós brincávamos juntos. Ele era um menino bem-educado, a família dele protegida por antigos senhores de escravos - os Paula Souza. Era matriculado no Coração de Jesus, um colégio em que não entrava qualquer um naquele tempo.

Um dia, reencontrei o Jayme de Aguiar. Já não era mais aquele moleque. Dei com ele num baile. Ele fez uma festa comigo. Era acostumado a frequentar bailes de sociedades. Só que tinha uma coisa que me incomodava. O Jayme de Aguiar, em todo nosso encontro, punha a mão no bolso e tirava um soneto e lia pra eu ouvir. E o que eu entendia de soneto? Outras vezes tirava uma crônica que ele não tinha onde publicar e lia também. Ele conhecia negros redatores de jornais...

Um dia o Jayme deu a ideia de fundarmos um jornal. E disse:

- Eu não tenho confiança em ninguém. Ninguém é meu amigo íntimo como você. Eu me encarrego da parte literária e você faz a outra parte, de tipografia e essas coisas. Concordei até com o nome que ele sugeriu: $\mathrm{O}$ Clarim. Fui à tipografia para saber o preço de um milheiro. Foi uma alegria quando saiu o primeiro número. Era

${ }^{272}$ Elite, 20 jan. 1924, p. 1 
pequenino, sem conotação política ou qualquer ideia da aproximação da comunidade negra. Era um jornal de notícias literárias, embora eu não fosse literato e mal tinha acabado de ter as primeiras noções de gramática. ${ }^{273}$

Segundo José Correia Leite, dada a falta de experiência dele e de Jayme de Aguiar, "não se tinha outro meio a não ser copiar o que as colônias estrangeiras faziam"274

O periódico inicia sua circulação em 6 de janeiro de 1924 com o nome $O$ Clarim. A partir de 13 de maio de 1924, seu nome é substituído por O Clarim D’Alvorada e seus diretores adotam os próprios nomes em substituição aos pseudônimos anteriormente utilizados $^{275}$.

Já os subtítulos sofreram diversas modificações. A primeira delas ocorreu em 3 de fevereiro de 1924, passando a Orgam Literário, Scientifico e Humorístico. Outra mudança ocorreu em 13 de maio de 1926, em uma edição especial do periódico, trazendo o seguinte subtítulo: Orgam Literário, Noticioso Pelos Interesses dos Homens de Côr. Na edição de 20 de junho de 1926, constava o seguinte: Orgam Literário, Noticioso e Humorístico. Em 13 de maio de 1927, passou a ser Orgam Literário, Noticioso, Pelos Interesses dos Homens de Côr de São Paulo. Nova mudança em 18 de junho de 1927, retomando o subtítulo de Orgam Literário, Noticioso e Humorístico. Em 5 de fevereiro de 1928, passou a ser Pelo Interesse dos Homens Pretos - Noticioso, Literário e de Combate. Já em 23 de agosto de 1930, o subtítulo seria modificado para Legítimo Orgam da Mocidade Negra, que permaneceria até 28 de setembro de 1940, data em que foi publicado o último exemplar do periódico, sem subtítulo.

O jornal teve duas fases sequentes: a primeira durou de 1924 a 1927; na segunda, entre 1928 e 1933, seu subtítulo foi alterado para pelo interesse dos homens pretos noticioso, literário e de combate. Nessa fase, o jornal passou a contar com outras pessoas, além de Jayme de Aguiar e José Correia Leite: Luiz de Souza (gerente), Urcino dos Santos e João Soter da Silva.

Houve ainda uma terceira fase, iniciada em 28 de setembro de 1940, porém apenas a edição inicial foi publicada.

Durante a primeira fase a redação situava-se à Rua Ruy Barbosa, 105, então residência de Jayme de Aguiar e, na segunda, a sede passou a ser à Rua Major Diogo, 131, onde morava José Correia Leite.

\footnotetext{
${ }^{273}$ Depoimento de José Correia Leite IN: SILVA, Luis. op.cit., pp. 26-29.

${ }^{274}$ Idem, ibidem, p. 33

${ }^{275}$ A mudança ocorreu para diferenciar $O$ Clarim do seu homônimo de Matão, um jornal espírita, conforme descrito por José Correia Leite em sua biografia.
} 
A interrupção entre a primeira e segunda fases se deu principalmente por motivos econômicos. Logo no início da segunda, Jayme de Aguiar anunciou que iria se casar e José Correia Leite passou a assumir a redação principal do jornal. O periódico encerrou suas atividades no início de 1933, após desentendimentos com alguns membros da Frente Negra.

O Clarim da Alvorada, ao contrário de seu mais significante par campineiro, Getulino, não apresentava um substancial portfolio de anunciantes, e dependia muito da arrecadação de suas tiragens, que variavam entre 1.000 e 2.000 exemplares. A publicação era mensal e em geral saia com atrasos devidos às dificuldades financeiras dos diretores. Sempre que possível, se associavam a outras organizações a fim de arrecadar fundos provenientes dos bailes. Leite confirma que "havia bailes até de segunda-feira. Estes eram cobrados, pois era muito difícil manter um corpo associativo". 276

Os números avulsos custavam $\$ 200$ réis e a assinatura semestral, 1\$000. A partir de 1926, as assinaturas passaram a ser anuais, chegando a custar $5 \$ 000$ em 1929 e $12 \$ 000$ em 1930.

Segundo Correia Leite, "os jornais da época, os pequenos jornais, circulavam nas ruas, mas o forte da distribuição eram os bailes ${ }^{277}$." Isso pode ser confirmado na segunda edição, com a nota "Agradecimentos":

\footnotetext{
Para demonstrar o nosso contentamento e gratidão pela feliz acceitação, aqui depositamos ás sociedades abaixo mencionadas os nossos agradecimentos:

XV de Novembro, XIII de Maio, Paulistano, Primaveras, Bandeirantes, Flor da Mocidade, União Brasil e Militar, Rio Branco e Princeza do Sul.

As senhoritas Iracema dos Santos, Valentina Miranda, Maria de Lourdes, Herminia Cruz e Nair Cruz, que se encarregam de vender no XV de Novembro.

Ao Grupo das Margaridas, pelas senhoritas Izaura Vianna e Lazinha Horta, e a senhora Anna Cunha da União Militar.

Aos senhores Aleixo Teixeira de Barros e Eustachio José Alves, presidentes honorario e em exercicio do XV de Novembro, os nossos agradecimentos ${ }^{278}$.
}

O jornal não tinha muitos anunciantes. Eles passam a se apresentar com maior frequência a partir do terceiro número: são advogados, costureiras, encanadores, músicos, motoristas e alfaiates, e o mais conhecido era o Biotonico Fontoura, que ocupava o maior espaço nos primeiros exemplares. Datas comemorativas, como o 13 de maio e o 28 de setembro, esta em homenagem à Mãe Preta, atraiam os anunciantes. A edição de 13 de maio de 1929, por exemplo, teve 27 anúncios publicados.

$\mathrm{O}$ grande número de clubes, associações e outras entidades dedicadas à congregar os afro descendentes na Capital, muito além daquelas já mencionadas em jornais da primeira

\footnotetext{
${ }^{276}$ Idem, ibidem, p. 46. Grifo nosso.

${ }^{277}$ Idem, ibidem, p. 45

${ }^{278}$ O Clarim, 3 fev. 1924, n. 2, p.1
} 
fase, como Smart, Kosmos, nos levam a acreditar que a classe média negra fosse mais consistente do que nos mostram os estudos de Florestan, Bastide, Moura entre outros. É uma hipótese a ser comprovada.

A melhor forma de saber o que se passava no meio negro era frequentar os pontos de encontro mais tradicionais de São Paulo:

\begin{abstract}
A Praça João Mendes era um ponto de concentração de muitos negros. Constantemente havia festas na Igreja dos Remédios, que eram bem na praça. Sempre se viam negros reunidos ali. Aqui em São Paulo nunca faltou um ponto de concentração. O principal - eu ainda me lembro quando era menino - fica ali onde é hoje o Pátio do Colégio. O lugar tinha o nome de Largo do Palácio. (...) Havia um jardim com coreto. Muitos negros iam lá para passear aos domingos para fazer hora e depois ir para os bailes. ${ }^{279}$

Os negros se reuniam ali na Rua Quintino Bocaiuva, Praça da Sé e Praça João Mendes, onde tinha um café chamado Café do Adelino. ${ }^{280}$
\end{abstract}

Curiosamente, José Correia Leite tomou conhecimento da comunidade negra depois de muito tempo: "para mim - disse ele - o meio negro foi um mundo novo. Eu tinha vivido até então com os italianos" 281 .

Pequenas notas ou sonetos de colaboradores italianos ou descendentes apareceram nos primeiros números. Na seção "U Clarino", o "Professor Doutor" João P. Carreta destaca sua impressão ante o primeiro número do periódico:

\title{
U Clarino
}

In nomi da ridaço agradeçu a tutos os pissualo que subero cumprihéndere us nobre principios desto organo, no suó primero numero.

Mamma mia qui bruto sucessu prus pissuale da ridaçó, quando vimos U CLARINO na mó di tuta gente. Ma ne tuto só icuale: arguno lero con satisfaçó otrus olharo pru formato piquinino...-Piccolino si má di coraçò grandi; Avemus ispirança di sere un gigante arguno dia...piano...piano si va lontano. ${ }^{282}$

Em outra nota, chamada "Telegrammi", faz alguns comentários sobre bairros da Capital, próximos à redação:

Telegrammi

Bixiga - Urgente. Num é pur sere u bairro da ridaçó, qui nois vamus aparlare bene. Noutrus tempus u Bixiga era abitadu puer giente disordieros i outrus maus elimento, ogi as coisas mudaro, só si ve gentes chikis, i tuto trabalhadores, a di andare sempri mais na ponta.

Libertá - (A). Un nomi giá dimonstrá suas bella qualitá, tira o chapello pra este bairro batutima.

Este bairro excellenti

da Elite da Libertá

\footnotetext{
${ }^{279}$ SILVA, Luis. Op.cit., p. 44

${ }^{280}$ Idem, ibidem, p. 61

${ }^{281}$ Idem, ibidem, p. 47

${ }^{282}$ O Clarim, 3 fev. 1924, n.2, p.4.
} 
mora la bona gienti

U mais perto da cittá.

Campos Eliço - Ritardatu. U bairro chikis du grupu du "Algentino" afamadu pelas suas notas carnavalesca. Tudos moços i moças basta seré dus Campo Eliço podi entrare $^{283}$

Não foi possível obter maiores detalhes sobre o autor dessas notas, nem confirmar sua legitimidade junto a outras fontes, pois os demais estudos sobre a imprensa negra não abordaram o relacionamento dos redatores com colaboradores da colônia italiana em São Paulo e nosso tempo seria exíguo para tal pesquisa. Porém, visto que os jornais eram muito criteriosos quanto à seleção dos textos para publicação, inclusive repreendendo publicamente os plagiados, acreditamos que os relatos sejam verdadeiros.

Os bairros mencionados pelo italiano nas notas acima, por sinal, eram os mais frequentados pela comunidade negra e onde estavam localizados a maioria dos anunciantes ${ }^{284}$.

Apesar de ser considerado por alguns autores, entre eles Miriam Nicolau Ferrara, o marco inicial para o segundo período da imprensa negra paulista na condição de um espaço de lutas e reivindicações, $O$ Clarim da Alvorada não expôs claramente esses objetivos desde sua primeira edição em janeiro de 1924, como observado nos primeiros subtítulos apresentados. Mais de dois terços do espaço eram dedicados a mostrar trabalhos de literatos negros, contos, poesias e eventos sociais, como foi comum a outros periódicos dessa imprensa. Mesmo assim, Jayme de Aguiar e Correia Leite já indicavam aos leitores alguns dos principais pontos do programa:

\section{INSTRUCCÇÃO}

[...] Também o adulto vae a escola. A escola é o recinto sagrado onde vamos em comunhão buscar as sciencias, artes, musica, etc. É na escola que encontramos os meios precisos para nos fazer entendidos pelos novos irmãos.

[...] Oh paes! Mandae vossos filhos ao templo da instrucção intellectual - a escola. Não os deixeis analphabetos como dantes!

Hoje temos tudo, aproveitae as horas noturnas si os trabalhos vos impedem. Ides à escola! Aproveitae o precioso tempo para engrandecer a nossa raça e o nosso querido Brasil... ${ }^{285}$

O trecho acima possui duplo significado: atenta para o cuidado dos pais em mandarem seus filhos à escola a fim de eliminar o analfabetismo, um mal que assolava a população negra e impedia seu crescimento, e manda uma mensagem aos adultos, que devem tentar o acesso à educação mesmo nas horas livres ou no período noturno, a fim de se elevarem como cidadãos.

\footnotetext{
${ }^{283}$ Idem, ibdem.

${ }^{284}$ Sobre bairros negros em São Paulo, ver o artigo Território negro na República branca IN: ROLNIK, Raquel. A cidade e a lei: política urbana e territórios na cidade de São Paulo. São Paulo: Studio Nobel, 1997, p. 75-78, e PONCIANO, Levino. Bairros Paulistanos de A a Z. São Paulo: Senac, 2001, p. 29.

${ }^{285}$ O Clarim, 3 fev. 1924, n. 2, p.2
} 
A "educação intelectual” anda de mãos dadas com a educação religiosa como forma de retirar o negro do desânimo e a alienação, como nos mostra um dos primeiros editais:

\section{IDEAL DOS IDEAES}

[...] Christo, conhecedor profundo das boas obras, já julgou aquelles tyramnos, castigando-os eternamente e, aos pobres martyres, deu-lhes a gloria eterna.

Nós patricios, que ainda vivemos sob suas ordens, tambem necessitamos de uma communhão quotidiana para o nosso engrandecimento - a communhão de idéas.

[...] Animae-vos! Lutae com fervor, dizei aos vossos entes queridos que necessitamos ser mais poderosos, tirando da nossa raça o emblema terrível, que nos desconsola innumeras vezes: "Escravo".

Dae aos vossos filhos a educação do amor de Deus e do amor da nossa raça.

A primeira para implantardes na mocidade de hoje, tão luxuriosa e sem moral os princípios básicos do além; a segunda a educação do amor aos nossos irmãos de raça, afim de seguirmos o caminho rectilinio do progresso. ${ }^{286}$

Para além do discurso moralista, Moyses Cintra ${ }^{287}$, seu autor, conclama os patricios a deixarem de pensar como escravos e se unirem através da educação, da religião e do bom comportamento.

Continuando, atribui a culpa de uma situação má ao próprio negro, que se preocupa mais com o aspecto festivo, e faz uma comparação com outros grupos étnicos:

É triste, mas é necessario que se diga, não o conhecemos [o progresso]!

As outras raças caminham para o progresso, numa avançada triumphal. Nós homens de côr, estamos marcando vagarosos passos. Porque?

Por nossa propria vontade...

[...] De que vale nos apresentarmos bem ás reuniões e diversões, bem trajados, quando nem sequer sabemos de como explicar os nossos sentimentos?

É necessario um pouco mais de bom senso em toda a linha ${ }^{288}$.

Algumas vezes a proposta de auxílio financeiro é feita de forma mais direta:

...seria preciso uma convocação geral dos homens pretos, e tratar da fundação de uma caixa beneficente, eleger a directoria, enviar manifestos a todos os estados do Brasil, e, emfim, fundar a sociedade "Confederação dos homens pretos" segundo as ideas de varios patricios.

Caros leitores, isto parece difficil, mas não é. Existe em São Paulo um elevado número de sociedades dançantes. Se reunirem todos os presidentes destas teremos já o suficiente para a primeira reunião, e, se cada presidente propagar em suas sociedades os principios nobres do centro, tambem teremos um bom numero de $\operatorname{socios}^{289}$.

\footnotetext{
${ }^{286}$ O Clarim, 6 abr. 1924, n. 4, p. 1

${ }^{287}$ Moyses Cintra era um dos pseudônimos de Jayme de Aguiar, redator e um dos fundadores do jornal.

${ }^{288}$ O Clarim, 6 abr. 1924, n. 4, p1.

${ }^{289}$ Idem, ibidem.
} 
A exclusão é tema de críticas no pós-abolição, mas a culpa é muitas vezes atribuída ao próprio negro:

Os pretos são amaldiçoados, mas se isto é facto, será por ventura, somente os do Brasil, sobretudo os de S. Paulo; exceptuando os de outras nações que progridem consideravelmente, engrandecendo a sua patria e a sua classe; e nós brasileiros pretos ficamos cheios de enthusiasmos quando contemplamos nos jornaes extrangeiros os progressos daquelles nossos irmãos de raça; porem, longe muito longe estamos de imita-los ${ }^{290}$.

Mesmo quando o cerne da mensagem é a diversão, existe um tom de responsabilidade presente:

VAMOS PINTAR O SETE?

[...] Preparemo-nos, portanto, dentre todas as festas que commemoramos, esta é a de maior brilhantismo empolgante.

[...] Esperamos anciosamente que, os Grupos Barra Funda e Campos Elyseos, ganhem aplausos de S. Paulo em peso, como nos annos anteriores. Quem sabe si neste anno apparecerá mais um Grupo de rapazes esforçados para ajudarem engrandecer os nossos? $?^{291}$ (grifo nosso)

Como já se deve ter percebido, os salões e associações sempre foram locais privilegiados de arregimentação de jovens colaboradores para os jornais negros, tanto que a maioria de seus líderes e diretores saiu das fileiras dessas entidades.

Chamou nossa atenção uma nota no segundo número do Clarim: a apresentação de uma colaboradora, fato raro entre jornais negros, cujo material publicado era sempre de autoria masculina:

\section{MARIA DE LOURDES SOUZA}

Temos o immenso prazer de apresentar aos nossos queridos leitores os trabalhos que figuram na $1^{\mathrm{a}}$. e $2^{\mathrm{a}}$. pagina - visto serem de uma senhorinha que se apresenta hoje a publico com suas collaborações.

É dotada de optimos preparativos desde já aproveitamos o ensejo para agradecer a distinta senhorinha Maria Lourdes Souza pelo seu futuro que será mais uma gloria ás gerações futuras. Esperamos que outtras procurem emital-la... ${ }^{292}$

Maria de Lourdes assina o poema "Amor Eterno" na primeira página e o conto "O Meu Primeiro Amor" na segunda.

O periódico combatia também a diferenciação existente dentro do próprio meio:

Pretos ou mestiços é uma cousa (sic) só, todos descendem da mesma raça; todos são negros. E porque tambem a idea (sic) não deve ser uma? Sendo uma só, a idea a lucta tambem será uma; porem caso contrario nunca haverá harmonia em nossa classe, e o preto deverá ser combatido pelo proprio preto ${ }^{293}$.

\footnotetext{
${ }^{290}$ O Clarim da Alvorada, 30 ago. 1925, ano II, n. 14, p.1

${ }^{291}$ O Clarim, 3 fev. 1924, n.2, p.2.

${ }^{292}$ Idem, ibidem, p. 3

${ }^{293}$ O Clarim da Alvorada, 22 ago. 1926, ano III, n. 24
} 
Com a mesma veemência, criticava a apatia e a submissão ao branco:

O preto até hoje, não cuidou da sua melhoria social; não tem cuidado de sua instrucção; não tem cuidado absolutamente de sua educação; e finalmente, parece querer viver sob a direcção e protecção do branco, na illusão insensata de que nada vale, de que nada pode!

Infelizmente, esta é a mais larga expressão da verdade, porém, a legítima protecção do branco, não veio totalmente ao encontro da raça negra do Brasil, porque depois que o negro deixou de ser a formidável machina productora, ficou só, parado na estrado do progresso ${ }^{294}$.

Por volta de 1928, O Clarim da Alvorada, em cooperação com o jornal Progresso, de Lino Guedes, tentou promover outro movimento, chamado por eles Frente Única, que unificaria todas as entidades ligadas ao movimento negro em São Paulo. Essa, como algumas iniciativas semelhantes, não foi bem sucedida, mas abriu caminho para outras, entre elas, a criação da Frente Negra Brasileira, sobre a qual trataremos mais à frente:

Frente única: quer dizer colligação de todas as forças physicas, de todas as energias de alma e de intelligencia da potencialidade total de alma e corpo em defeza intellectual, moral e economica, já não de um individuo, mas de toda uma raça, de todo um povo. (...)

Na hora em que o Brasil vae reunir o seu Congresso Constituinte, dando uma nota ao Brasil novo os homens e mulheres de raça negra devem comprehender e batalhar para que nesse Congresso o negro tenha sua representação de seus legitimos irmãos de raça, para pensarem e realizarem por força de lei, tendo quanto ao homem e a mulher de raça negra tenha até hoje faltada por haver vozes que se levantem no parlamento nacional, em defeza dos seus grandes anceios de cultura e perfeição. Homens e mulheres da raça negra batalhae com ardor para que no alto conselho da nação a vos do negro se levante como uma tuba de guerra impondo ao Brasil, para a raça, os esplendores da Justiça. ${ }^{295}$

Naquele momento, o Clarim da Alvorada vivia sua segunda fase, marcada pela expansão para outras regiões do país e do Estado: há representantes na Capital, Rio de Janeiro, Santos, Pindamonhangaba, Botucatu e Bahia.

Apesar disso, as dificuldades financeiras são flagrantes. A edição de 3 de fevereiro de 1929, após "um involuntário descanso", pedia a colaboração dos assinantes:

Estamos procedendo o recebimento das assignaturas desta folha e pedimos aos nossos bons amigos o seu prompto auxilio a esta empresa que vem luctando com sérias difficuldades... ${ }^{296}$

Em 1929, Jayme de Aguiar iria se casar e anunciava a José Correia Leite sua intenção de encerrar as atividades do jornal. Leite não aceita a decisão e expõe seus planos: fazer um jornal diferente, como conta ele próprio:

\footnotetext{
${ }^{294}$ O Clarim da Alvorada, 1 jul. 1928, anno I, n.6

${ }^{295}$ Progresso, 15 nov. 1931, n. 42, p.1.

${ }^{296}$ O Clarim da Alvorada, 3 fev. 1929, p.4
} 
O Clarim d'Alvorada foi tomando um certo impulso, ficando mais conhecido. Até que um dia o Jayme de Aguiar veio para mim - ele estava noivo - e anunciou que pretendia se casar e não teria mais tempo para o jornal, que ele pretendia que acabasse. Mas, como eu já estava com o "bicho", com o "verme", eu disse:

- Não. O jornal não vai acabar. Você vai casar, mas o Clarim vai continuar. Eu dou um jeito.

- Mas José, você não tem preparo para isso...- e veio com aquele conversa, ao que eu logo respondi:

- O jornal pode sair com vírgula errada, com erro de concordância, mas vai sair. Porque agora eu tenho uma ideias. Eu acho que nós estamos fazendo um jornal errado. Vamos fazer um jornal diferente... - e coisa e tal.

Então ele saiu, certo de que eu ia fazer besteira. ${ }^{297}$ (grifo nosso)

Utilizando-se de um velho artigo de Vicente Ferreira, quando este ainda militava no Rio de Janeiro e com o auxílio de Lino Guedes para a elaboração da página de fundo, além de outros companheiros, José Correia Leite lançou uma edição especial em homenagem ao Dia da Mãe Negra, em 28 de setembro. A partir daí, O Clarim da Alvorada assumia a postura de um jornal de luta, denúncias e reivindicações de direitos.

Vicente Ferreira era conhecido orador, tornando-se conhecido no meio negro como o "tribuno do povo". Além disso, foi por algum tempo colaborador de Correia Leite na redação do Clarim da Alvorada. Sua primeira aparição ocorreu durante o sepultamento do então presidente do Estado de São Paulo, Carlos de Campos, em 1927. Era também chamado de "Professor" Vicente Ferreira, um "negro alto, magro, de voz imponente". Depois se descobriu que, na verdade, era semi-analfabeto. Conseguia debruçar-se horas sobre livros, jornais e outras publicações em bibliotecas e outras entidades, mas não era capaz de escrever. Permaneceu por um bom tempo colaborando com a redação de O Clarim da Alvorada, com sugestões para artigos e na divulgação do jornal até 1932, quando passou a frequentar a Frente Negra Brasileira.

Sobre ele, assim falou Raul Joviano do Amaral, também colaborador importante do Clarim da Alvorada e da Frente Negra Brasileira:

Eu cursava a Escola de Comércio Álvares Penteado. Houve a inauguração da herma de Ruy Barbosa, no Vale do Anhangabaú. Houve discursos oficiais, grande oratória. Ao fim da solenidade oficial, as autoridades desceram do palanque e a multidão começou a ser dispersar, quando um negro mal vestido, pediu a palavra. Era Vicente Ferreira. Ninguém deu atenção. Ele então começou a falar, fez uma oração grandiosa a Ruy Barbosa, cuja vida conhecia muito bem. Aos poucos todos foram parando e voltaram para ouvir Vicente Ferreira. Se dizia jornalista e orador popular. Tinha uma memória fabulosa. Passava dias inteiros nas bibliotecas e decorava tudo o que lia. $^{298}$

\footnotetext{
${ }^{297}$ Idem, ibidem, p. 40

${ }^{298}$ Depoimento pessoal de Raul Joviano do Amaral a Miriam Nicolau Ferrara. op. cit., p.84.
} 
Mesmo sendo figura folclórica e carismática, era reconhecido por sua influência nos jornais negros:

Foi ele que induziu o grupo do jornal [O Clarim da Alvorada] a reivindicar direitos, alertou quanto aos prejuízos que os negros sofreram com a escravidão. (...) Ele lia e não escrevia. Ele nunca escreveu, nem o nome dele. Mas ele era um grande orador, participava de tudo e a grande preocupação dele era o negro.

Qualquer acontecimento ele aparecia, e pedia a palavra, e entrava no barulho, colocava o negro em primeiro lugar. Fosse o que fosse, ele sempre dava um jeito de exaltar o negro. Vivia no meio de intelectuais, fazia conferências sobre a raça negra, que tinha para ele grande importância. Foi um teórico da causa negra e muito contribuiu para a união dos negros. ${ }^{299}$

Um assunto em discussão nos anos 1920 foi a volta para a África dos descendentes dos antigos escravos. Não consta nas fontes pesquisadas que Correia Leite tenha aderido às ideias de Marcus Garvey sobre Panafricanismo ${ }^{300}$. O Clarim da Alvorada chegou a publicar alguns artigos em uma coluna chamada Mundo Negro, em alusão ao nome do jornal que Garvey publicava nos Estados Unidos, mas ao que parece a iniciativa não seguiu adiante. Na verdade, era uma tradução da homônima norte-americana, com o discurso de exaltação bastante parecido ao "nacional":

[...] As paginas da historia nos demonstram, apesar da pouca consideração de que somos objectos, os dotes de intellectualidade dos verdadeiros directores da Raça, que advogam pelo seu enaltecimento e seu bem estar.

Cooperemos com elles á todo custo. Desgraçadamente temos sido relegados na costa dos papeis inuteis ${ }^{301}$.

Correia Leite dizia enfrentar preconceitos até mesmo dentro da comunidade negra, por não ser considerado "tão negro assim". Na verdade, a cor mais clara de sua pele e seu relacionamento com os italianos na infância e adolescência o estereotipavam consideravelmente. Além disso, havia o sutil preconceito por parte do branco, presente nas palavras do militante:

\footnotetext{
${ }^{299}$ Depoimento pessoal de José Correia Leite a Miriam Nicolau Ferrara. Op. Cit., p.84.

${ }^{300}$ Marcus Mosiah Garvey nasceu em Saint Ann's Bay, Jamaica, em 17 de agosto de 1887, e faleceu em Londres em 10 de junho de 1940. Foi um comunicador e empresário jamaicano, considerado um dos maiores ativistas da história do movimento nacionalista negro. Garvey liderou o movimento mais amplo de descendentes africanos até então; é lembrado por alguns como o principal idealista da "volta para a África". Na realidade, criou um movimento de profunda inspiração para que os negros tivessem a "redenção" da África, e para que as potências coloniais européias desocupassem a África. Em suas próprias palavras, "Eu não tenho nenhum desejo de levar todas as pessoas negras de volta para a África, há negros que não são bons elementos aqui e provavelmente não o serão lá." Apesar de ter sido criado como metodista, declarava-se católico. Para maiores detalhes sobre Marcus Garvey e Panafricanismo, ver The Philosophy and Opinions of Marcus Garvey. (Editado por Amy Jacques Garvey.); The Poetical Works of Marcus Garvey (Editado por Tony Martin.) e GARVEY, Amy Jacques. Garvey and Garveyism. Londres: Collier-MacMillan, 1968.

${ }^{301}$ Eduquemos nossas massas. Manifesto "Negro World" apud O Clarim da Alvorada, 3 fev. 1929, p.1
} 
Essa coisa de quando você estava numa roda de brancos e queria discutir alguma coisa com relação ao negro, eles logo deixavam você sem assunto, tapavam sua boca com o argumento:

- Não, aqui não tem nada disso. Tanto que você está aqui com a gente!

Eles faziam isso, mas não sabiam que ao dizerem "tanto que você está aqui com a gente" comprovavam a pior espécie de preconceito. Por que, no fundo, o que estavam dizendo? Que estavam aceitando você por favor, por você ser um negro diferente, ou qualquer coisa, mas sem igualdade. $(. . .)^{302}$

As lutas mais importantes de $O$ Clarim da Alvorada diziam respeito à conscientização do negro sobre sua importância dentro do contexto histórico do Brasil, sua elevação moral, seu direito à educação, trabalho, saúde, habitação, além da promoção de um espaço aberto para denúncias contra preconceito e discriminação:

O negro foi substituído pelo immigrante, o pobre ficou sem norte, illudido com sua carteira de eleitor e com o seu titulo de cidadão brasileiro, mas, não o ensinarãm (sic) a ler nem a escrever; classificado pelos altos sociologos, descendentes de raça inferior $^{303}$.

Para implementar ações contra a exclusão, um caminho poderia ser o da atuação política. Frederico Baptista de Souza, colaborando com o artigo "O negro deve ser político?" expõe sua opinião:

O negro deve ser político, comprehendendo os deveres do bom e do util, não político pelo mero prazerem ser agradavel a este ou aquelle, sem vontade propria; deve ser politico, porem debaixo de uma organização,com programma definido, organização esta que possa produzir interesses à raça negra.

Verdade é que ouvimos a cada passo se dizer que o negro não tem habilitação nem capacidade, puro engano; o que há é que muitos renegam a sua origem; nem só esta, mas a própria cor! Para que, não nos envergonhemos de ajudal-o com o nosso voto, a galgar uma posição elevada e honrosa para os proprios negros ${ }^{304}$.

Em junho de 1929, O Clarim da Alvorada lançou a ideia do I Congresso da Mocidade Negra. Além de Correia Leite, participavam da iniciativa Arlindo Veiga dos Santos, então professor do Ginásio São Bento, o poeta Dr. Evaristo de Morais, e mais tarde Argentino Celso Wanderlei ${ }^{305}$, à época presidente do Cordão Carnavalesco Campos Elíseos. Na edição de maio, Correia Leite anuncia os planos para a realização do evento:

(...) E a época é dos congressos custe o que custar realizar o nosso I Congresso à Mocidade Negra, deve-se congregar nesta affirmação patriotica, dando ao Brasil, uma nova demonstração; levantando o labaro da nossa rehabilitação no conceito nacional.

\footnotetext{
${ }^{302}$ SILVA, Luiz (CUTI). ...E disse o velho militante ... op. cit., p. 81

${ }^{303}$ O Clarim da Alvorada, 1 jul. 1928, anno I, n. 6, p. 1

${ }^{304}$ O Clarim da Alvorada, 27 out. 1929, n.21, p.1

305 É importante ressaltar que Argentino é o primeiro nome, não referindo-se à sua nacionalidade, como pode ser visto erroneamente em algumas fontes.
} 
O nosso labor em torno da realização do primeiro congresso da mocidade negra, despertou no seio da raça que, hoje, comemora e festeja, calorosamente, a extincção do trabalho servil, pelo menos, o enthusiasmo de uma nova rota para se seguir, attravez da evolução hodierna no seio da patria livre. (José Correia Leite) ${ }^{306}$

Mas é a mensagem de Arlindo Veiga Santos, na edição de 9 de junho de 1929, que manifesta de forma mais contundente a necessidade do Congresso. Esse discurso anuncia algumas das ideias nacionalistas que Arlindo pregaria em $A$ Voz da Raça, como veremos mais adiante:

[...] Se, como fala Pontes de Miranda, os estrangeiros apoderaram-se do país e o brasileiro assiste indiferente à conquista tenaz e cobiçosa, não é verdade isso a respeito do Negro. Oh! Se o Negro altivo, o Negro orgulhoso do seu passado nacional...Ah! se o Negro pudesse! Se o Negro de fibra mandasse...

[...] Consegui-lo-emos (Deus quer), pela educação e levantamento moral, intelectual e econômico, bem como pela organização das nossas famílias, e especialmente da nossa mocidade, esperança de melhor futuro - dentro do espírito tradicional da nacionalidade, único que pode conservar e preservar o Brasil brasileiro.

[...] O Brasil, diz Castro e Silva, precisa de uma metafísica sociológica, mas de metafísica brasileira. Auscultando a nossa realidade, tiraremos da consideração dela o remédio para nossos males, negando atenção àqueles que queiram "salvar-nos" contras as nossas tradições e contra o Brasil.

Tenhamos fé, e esta fé nos indicará o caminho a seguir. Seja cada um de nós um obreiro desta reação contra o sonegamento dos direitos sagrados da Gente Brasileira de cor; seja cada qual um soldado contra a decadência dos nossos costumes, contra o derrotismo dos perversos e traidores, contra a ignorância e os preconceitos existentes, embora muitos queiram negar; contra o imperialismo dos advenas, contra a ideia e a política estrangeira arianizante; e sobretudo, mais que tudo, contra a negação do que foi feito, pode fazer e quer ainda fazer o nosso Sangue - cuja nobreza foi conquistada nas artes, nas ciências, na política e na guerra, pela identidade, unidade e a independência nacionais.

[...] Pregai o Congresso. Pais negros chamai a postos vossos Filhos. Moços patrícios, cheios de boa vontade e esperança de vencer, acorrei ao vosso Congresso, para alimentar a vossa fé e retemperares o vosso coração para o bem e o ideal. Sede aderente ativo do Congresso da Mocidade Negra Brasileira!

Pela Raça e pela Pátria!

P/ Comissão Org. Arlindo Veiga dos Santos ${ }^{307}$

Entretanto, por escassez de recursos financeiros (o jornal não poderia custear a viagem e hospedagem de representantes de outras cidades e Estados) e falta de adesão da comunidade negra, o evento não aconteceu.

Como se sabe, em fins de julho de 1929 houve o lançamento da campanha eleitoral às eleições presidenciais de março de 1930, com a candidatura de Getúlio Vargas e a formação da Aliança Liberal. A iniciativa partiu de Minas Gerais e do Rio Grande do Sul, que se opuseram à chapa governista Júlio Prestes-Vital Soares, com posterior adesão da Paraíba.

\footnotetext{
${ }^{306}$ O Clarim da Alvorada, 13 mai. 1929, n. 16, p.1

${ }^{307}$ O Clarim da Alvorada, 9 jun. 1929, n. 17, apud SIQUEIRA, José Jorge. Entre Orfeu e Xangô: a emergência de uma nova consciência sobre a questão do negro no Brasil (1944-1968). São Paulo: Pallas, 2006, pp. 82-83.
} 
O negro nutria em relação à Revolução de 1930, sentimentos principalmente de esperança, na medida em que mudanças na ordem política poderiam permitir melhores condições de vida na sociedade que ele havia ajudado a construir. $\mathrm{O}$ simples fato de ver “aquelas famílias escravagistas apeadas do poder” era algo que já valia a pena.

No entanto, pouca coisa mudou para ele no país. A revolução de 1930 era apoiada pelas lideranças negras no sentido de que o vazio no poder poderia abrir espaço para o próprio movimento revolucionário dentro da comunidade negra. Entendemos que a criação da Frente Negra em 1931 foi uma tentativa nessa direção.

Como já dito páginas atrás, o Clarim da Alvorada continuou suas atividades de forma intermitente até 1933, quando um desentendimento entre José Correia Leite e Arlindo Veiga dos $\operatorname{Santos}^{308}$, aliado às dificuldades financeiras, fez com que as publicações fossem interrompidas. Mesmo assim, consideramos a segunda fase (1928-1933) como o período de amadurecimento ideológico do jornal, aspecto que trataremos no capítulo seguinte. Suas lutas e reivindicações influenciariam a criação de outras organizações, incluindo a Frente Negra Brasileira.

Cabe lembrar também que nesse período importante de crescimento e desenvolvimento da imprensa negra em São Paulo surgiram ainda outros periódicos, entre os quais Auriverde, O Patrocínio e Progresso.

\section{Auriverde}

Com o subtítulo Orgam Literario, Humorístico, Noticioso, O Auriverde foi fundado em abril de 1928, cujo diretor presidente era João Augusto de Campos e Deocleciano Nascimento, fundador de O Menelik, era seu redator. Publicado semanalmente, sempre aos domingos, a única exceção ocorreu no dia 6 de maio daquele ano por ocasião dos preparativos para o 13 de maio. Assim disseram os responsáveis, sobre a aceitação do jornal:

\footnotetext{
A Nossa folha

Ficamos satisfeitíssimos, em ver a grande acceitação que obteve a nossa minúscula folha, por parte dos que nos honraram em a ler; pois, já contamos com um numero elevado de leitores, que nos apoiaram,enthusiasmadamente, encorajando-nos a sustentar o nosso ideal de mantel-a, sempre com o intuito de visar os interesses da classe preta. Contudo isto, cremos que a quem duvide que a nossa marcha, apenas iniciada, vá além, e que será difficil sustentarmos ella semanalmente ${ }^{309}$.
}

\footnotetext{
${ }^{308}$ Veremos detalhes sobre esse conflito mais adiante.

${ }^{309}$ Auriverde, 8 abr. 1928 , n. 2, p. 1
} 
Era vendido por assinaturas mensais ao custo de $1 \$ 000$ réis, e semestrais por $5 \$ 000$. Composto por quatro páginas, poderia ter esse número ampliado dependendo da ocasião, como o 13 de maio. Publicava vários anúncios que em sua maioria encontravam-se na última página. Possuía a sua própria tipografia, localizada na Rua Turiassu n ${ }^{\circ} 47$ e um escritório na Rua Dr. Álvaro de Carvalho $\mathrm{n}^{\circ} 34$. As cobranças das assinaturas eram feitas através de notas publicadas no próprio jornal, expediente que como já ressaltamos, era comum nos jornais da imprensa negra. Algo pouco comum era a informação sobre a tiragem:

Para bom andamento de nossas tiragens e entregas aos nossos assignantes, rogamos que efectuem seus pagamentos da forma que lhes aprouverem. Vejam os endereços na seção Expediente. Tiragem provisoria 2.000 exemplares. Pedimos aos nossos assignantes, procurar-nos nos endereços acima, afim de saldar suas assignaturas ${ }^{310}$

O processo de seleção das colaborações enviadas ao jornal era tratado com bastante seriedade e eventuais disparidades, comentadas de forma a se evitar o plágio:

\footnotetext{
Secção dos novatos

O Auriverde, desobrigando-se do programa entre a mocidade negra de São Paulo, tem immenso prazer de acolher todas as collaborações que apresentem caracteristicos inegaveis de autenticidade.

Temos sobre a meza, um numero respeitavel de trabalhos necessitando emendas, mas que afinal, trazem um aspecto de propriedade do "autor". E nós daremos publicidade a todas ellas mas reservamos o direito de corrigenda.

Chegou nos todavia, ás mãos um trabalho em versos assignado pelo sr. Francisco E. do Carmo, o qual não nos é desconhecido, isto é, conhecemos o autor de uma das poesias que é o grande Fagundes Varella.

Dest'arte, deixamos de publical-a e avisamos o nosso amavel collaborador que não torne nessa symptomatica mania, de "biscoitar" producções alheias, o que nos obrigará a castigal-o merecidamente.

E por conhecer-mos esta deixamos de acreditar nas outras que a acompanham, mesmo porque a correteza orthografica das estrophes contrasta lamentavelmente com a dedicatoria e trecho para uso da redacção.

Ahi fica o aviso aos interessados.

A REDAÇÃ̃O 311
}

Eram publicadas notícias sociais de algumas associações e de outros periódicos, além de eventos esportivos e culturais. Na edição de 29 de abril de 1928, Deocleciano Nascimento comenta os planos para a realização do Congresso da Mocidade Negra, que como dissemos não se efetivou:

\section{CONGREGADOS}

\footnotetext{
${ }^{310}$ Auriverde, 8 abr. 1928 , n. 2, p.3

${ }^{311}$ Idem, 13 mai. 1928 , p.3
} 
Ouvi os grandes e pequenos comentarios tecidos pelos patricios de lá a respeito de nosso actual desenvolvimento (...).

Temos agora mais dois novos jornaes: o Auriverde nesta Capital e o Patrocinio em Piracicaba, que estão dispostos a luctar ao lado do Clarim d'Alvorada em prol de nossa gente.

[...] Então interpelei-o - O que me diz, a respeito da tomaria cívica idealizada pelo Clarim? - Ora amigos, podes desde já scientificar-se que adherem todas as nossas associações, principalmente o Palmares que se apresentará com os seus socios; e os nossos oradores consagrados Vicente Ferreira, B. Florencio, e Gervasio, farão as orações brilhantes do grande dia, inclusive a minha pessoa, que já se compromettera fazer em improviso discurso na séde do nosso Club, que não quer deixar em branca nuvem a data da fraternidade brasileira ${ }^{312}$.

Notamos que os primeiros artigos, assinados por Moyses Cintra e Henrique Cunha, já haviam sido publicados em outros jornais, como O Clarim da Alvorada, que era inclusive anunciante do periódico. Mas entendemos ser esse um procedimento normal considerando a grande cooperação entre membros das redações e associações.

Havia uma coluna com o nome de "Charada", onde eram feitas algumas perguntas ao leitor e no número seguinte, publicavam-se as respostas. Esse expediente possivelmente pode ter contribuído para uma maior vendagem, visto que o leitor poderia sentir-se motivado a verificar o acerto de suas respostas às perguntas feitas no número anterior.

\section{O Patrocínio}

Com o subtítulo Orgam Literário, Crítico e Humorístico, foi fundado em 1928 em Piracicaba como uma sociedade anônima, de periodicidade quinzenal. Alberto de Almeida era seu principal redator. Normalmente era composto de quatro páginas, mas o exemplar especial de aniversário chegou a apresentar oito. Uma assinatura anual custava $5 \$ 000$ réis e o número avulso, \$200, sempre mediante pagamento antecipado.

Os principais colaboradores foram Bento Escobar, Jayme de Aguiar, Josephina Toledo, Benedicta Prado, Anezio de Souza e Gervasio de Moraes.

O periódico possuia poesias, textos literários, contos e piadas. Apresentava algumas colunas fixas, como: "Sociaes", com notas sobre batizados, aniversários, falecimentos e bailes. "Rebarbos", era outra coluna dedicada a críticas a comportamentos dos negros e da sociedade como um todo, e "Machadadas", crítica a respeito de membros da sociedade piracicabana. Continha diversas propagandas.

${ }^{312}$ Auriverde, 29 abr. 1928, p.1 
A edição de 7 de setembro de 1928 traz o poema "Carvão Nacional", um trecho do livro $O$ canto do Cysne Preto de Lino Guedes:

\author{
CARVÃO NACIONAL \\ Um diabinho é Aracy \\ Parece até um sacy \\ A travessa da negrinha \\ Em certa roda de samba \\ Fica a gente meio bamba \\ Com a graça da tiasinha \\ Indiscretos arregaços \\ Da saia mostram os passos \\ A poesia que tem \\ $O$ samba. Ella requebrando \\ A todos vae convidando \\ Para dansarmos tambem. \\ E a Aracy, um certo dia \\ Apparece, quem diria, \\ Feita estrella theatral! \\ $E$ ao refulgir da ribalta \\ Toda a negrada se exalta \\ Com o carvão nacional. ${ }^{313}$
}

A redação registrava o recebimento e os comentários sobre os novos livros do exredator do Getulino:

Recebemos do sr. Lino Guedes, brilhante jornalista e escriptor patricio, dois livros de sua autoria, intitulados; "O Canto do Cysne Preto" e "Black".

Dificil nos é fazer um julgamento do valor dos dois livros de Lino Guedes, pois que não está na nossa alçada de simples principiantes que vimos fazendo o nosso aprendizado sem mestres, para dizer algo das obras do nosso distincto patricio. Entretanto, uma cousa é preciso que se diga: é que não podiamos receber, ler e guardar estes livros, sem que falassemos delles.

(...) Primeiro, porque são livros escriptos por um preto, que os escreveu para os pretos lerem; segundo, porque são de facto bem escriptos e attrahentes.

Lendo "Black" a gente encontra atravez de suas páginas, um grito de protesto contra o preconceito de cor que certos extrangeiros pretendem alguma vez subordinar os pretos brasileiros. É um protesto vibrante e audacioso em que o autor fala sem pejo tudo quanto sente.

“O Canto do Cysne Preto" é o contrario. É a poesia negra cantada por um negro, como toda a sua simplicidade e graça. É um ensaio da literatura negra que surge inspirada no genio poetico de Lino Guedes ${ }^{314}$.

A cooperação com outras associações e jornais negros era bastante intensa, como no caso do Centro Cívico Palmares, visível no texto que se segue:

\footnotetext{
${ }^{313}$ O Patrocínio, 7 set. 1928 , n. 31, p.1

${ }^{314}$ Idem, ibidem, p. 2
} 


\section{CENTRO CIVICO PALMARES}

Recebemos da secretaria da pujante organisação negra de S. Paulo, que è o Centro Civico Palmares, um expressivo e honroso officio com data de 1 do corrente, no qual a sua dignissima directoria faz sentir o desejo de organisar uma caravana Palmarina para visitar a nossa cidade, ainda em fim deste mez si for possivel.

Entretanto, podemos desde ja adiantar aos homens de cor de Piracicaba e aos Palmarinos da Capital, que a aspiração do Centro C. Palmares será brevemente realisada, ainda mesmo que não seja para este mez, pois que ja se nota a boa impressão que a noticia causou em nosso seio social ${ }^{315}$.

O principal objetivo do jornal era o reerguimento da raça negra, com forte cunho moralista, ao procurar trazer aqueles considerados "desviados ao caminho do dever". Teceu críticas a atitudes e comportamentos dos negros piracicabanos, e defendeu o nivelamento moral da raça negra, a fim de acabar com o estigma de inferioridade e indolência que recaía sobre a mesma.

O periódico incentivava também a instrução pública e católica como fator importante para o desenvolvimento do Brasil. Freqüentemente, conclamava a "classe negra piracicabana" a participar do I Congresso da Mocidade Negra do Brasil, considerado de suma importância para a unidade, reintegração dos direitos, discussão e luta em benefício do segmento negro. Há inclusive o comentário sobre um congresso norte-americano usado como incentivo à mobilização:

\section{UM CONGRESSO DE CATHOLICOS DA RAÇA NEGRA}

Realisou-se em Nova York o $3^{\circ}$. Congresso Annual de Catholicos Negros.

(...) Os Estados da Federação que têm a seu cargo organisar estas reuniões annuaes manifestam que o fim dellas é obter uma maior união e mutua intelligencia entre os catholicos negros; promover entre elles a educação catholica; elevar o seu nivel social por meio da egreja; desenvolver a intervenção dos negros catholicos em todo o que se refira á direç̧ão dos assumptos nacionaes.

(...) A raça negra nos Estados Unidos, apezar do grande abandono que tem jazido e ainda da hostilidade com que a olham, vae dando provas da sua capacidade intellectual, cada dia mais patente ${ }^{316}$.

O Congresso é citado como forma de eliminar o preconceito e a discriminação, atacando também a apatia que toma conta dos afro descendentes, que não se preocupavam com os assuntos mais importantes do meio negro:

Que fez elle para ser assim tão desprezado, si muitos possuem as vezes mais competencia que aquelle que occupa tal cargo?

Só porque é negro, unicamente a cor, patricios.

\footnotetext{
315 Idem, ibidem, p.3
}

${ }^{316}$ Idem, ibidem. 
Emquanto vemos mocinhas bem trajadas que vão para seus cargos nos escriptorios, rapazes que muitas vezes não sabem nem siquer falar a lingua de nosso paiz, caminham para seus postos elevados, ao passo que nossa irmãs caminham para as casas dos patrões, nossos irmãos caminham para as officinas e outros labores mais infimos.

Porque?

A culpa é toda nossa por sermos surdos ao grito de revolta de nossos irmãos, por possuirmos o orgulho, o preconceito, que precisa ser abolido do seio do negro.

É necessario que um negro divise no outro um irmão em cor e em ideal; por de parte as criticas, os desanimos e pensar exclusivamente no ponto culminante da victoria.

Mas perguntareis vós, qual seria esse ponto?

O Congresso da Mocidade Negra!

Sim, patricios, só o Congresso é que poderá concluir o ideal sonhado por Luiz Gama, José do Patrocinio e outros.

Precisamos deixar um pouco de parte o baile e outras diversões que nada nos traz de utilidade, e batalharmos para erguer a bandeira da victoria, prova do esforço grandemente satisfactorio e significativo do negro, que possue sentimento, caracter e $\operatorname{dignidade}^{317}$.

Em outro artigo, o negro é exaltado como elemento forte, mas o desanimo e a asfixia social o impediam de levar seus planos adiante:

\section{O Negro}

A nostalgia e a languidez do africano com certeza influiu muito na formação moral dos homens pretos do Brasil. O brasileiro como producto distincto de tres raças: a portugueza, a africana e a indigena, que traziam em si o estigma da resignação, é triste.

Portanto, o negro è, dentre os brasileiros, o que mais de perto soffreu essas influencias e as conservam ainda, devido aos injustos preconceitos que infelizmente ainda existem, mas que elles, com muita dignidade, sabem desprezar.

(...)

Entretanto, Cruz e Souza, Frederico Alvarenga, Gonçalves Dias, Luiz Gama, José do Patrocinio, Manoel dos Passos e outos mais, respectivamente na poesia, na literatura e na musica, provaram suficientemente que o negro é susceptivel de illustração, tanto ou mais ainda que os seus irmãos de differentes raças. Hoje contamos dentro de nossa classe com um infinidade de homens letrados, doutores, professores, jornalistas, poetas, tribunos e um importante bloco de mocidade estudiosa. Com excepção desta grande avalanche - muito desunida infelizmente - a maioria dos negros que vivem espalhados pelo nosso paiz encontra-se ainda moralmente escravisada. Ao traçarmos estas linhas temos em mente a experiencia que longos annos nos legou. A classe preta relegada para a ultima posição na escala social, sempre viveu asphixiada, sem estímulo, sem apoio para as suas mais modestas iniciativas.

Vem dahi o retrahimento e o desanimo deante de emprehendimento de vulto, como é este do $1^{\circ}$ Congresso da Mocidade Negra.

Mas esse punhado de moços estudiosos e esforçados que em boa hora lançaram a grande idéa, mais hoje, mais amanhã, verão seus esforços coroados de exito, porque será o congresso o unico meio pratico de se reunir as forças esparsas que possuimos, para com ella levantar-se a moral da nação ${ }^{318}$.

${ }^{317}$ O Patrocínio, 23 mar. 1930, anno 4, n. 51, p.2

${ }^{318}$ O Patrocínio, 19 out. 1930, anno 5, n. 55, p.1 
Em artigo assinado por Alberto de Almeida, o comportamento da mocidade era observado de forma moralista, como já dissemos:

\section{MEU CATHOLICISMO}

Eu muito poucas vezes vou á igreja. Porisso mesmo, passo até por atheu. Porém, quando entro numa dessas casas sagradas, entro tão somente para rezar e, mesmofaço muito amiude as minhas orações, porque quasi nem sei rezar...Rezo o sufficiente para implorar a Deus, pela remissão dos meus peccados.

(...)

Outra cousa que nunca gostei de fazer é acompanhar as procissões; porque em geral tanto os moços como as moças gostam de acompanhar estas festas religiosas, mais para namorar e reparar os defeitos dos outros que mesmo por espirito de devoção ${ }^{319}$.

Em outro artigo assinado por Benedito Conceição, foi possível notar que Almeida também era alvo de críticas por parte da sociedade piracicabana:

\section{O PATROCINIO E A SOCIEDADE NEGRA}

(...) os negros de Piracicaba, com pouca excepção, entenderam não recompensar os esforços desse abnegado abolicionista do captiveiro moral em que vive a raça negra. Mesmo assim este batalhador não desanima: sente-se sempre vigoroso, capaz de todas as prosperidades, com animo e poder para maiores emprehendimentos ${ }^{320}$.

\section{Constantemente o periódico apelava para que o povo piracicabano assinasse e} contribuísse para a sua manutenção:

\section{RECOMPENSA?}

Quando iniciamos nesta pequena lucta, verdadeiramente infausta e desigual, tivemos em mira unicamente um fim: - prestar pequenissimos e desinteressados serviços á nossa classe, que na opinião de muitos é a ultima na escala social. Queriamos e queremos ver os homens de cor unidos, trabalhando todos para o bem estar commum, reunidos em sociedades que nos educassem e elevassem nos a um certo grau social, de modo a não ficarmos tão distanciados das outras classes.

E para isso nos atiramos doidamente para o campo da pratica, sem recursos e cabedal intellectual, fundando e procurando manter com difficuldades, este pequeno porta-voz, para fazer de todo elle propaganda em beneficio unico e exclusivo dos homens negros piracicabanos. Temos enfrentado ja varias provas difficeis, e, sem desanimo procuramos solucional-as de modo a não deixar interromper a nossa marcha; temos chegado a pedir auxilios ás nossas sociedades para cobrir as nossas despezas, depois de já termos dado e gasto tudo quanto podiamos dar; e "O Patrocinio" continua assim, representando uma classe que é na maioria das vezes esquecida pelas outras classes mais abastadas.

Finalmente em recompensa ao nosso pequenissimo e desvalioso serviço, temos sido alvos de inveja, das intrigas e falsidades e outras tantas coisas que servem apenas para desvalorizar-nos em nossas idéas.

\footnotetext{
${ }^{319}$ Idem, ibidem.

${ }^{320}$ Idem, 29 jun. 1930, anno 4, n. 54, p. 3
} 
Não obstante isso tudo, continuaremos em marcha compassada e efficiente, enquanto tivermos provisão para nos manter, porque, em verdade não é atraz de recompensa que andamos; - o que nós queremos é luz e muita luz ${ }^{321}$.

Contava com a colaboração do Clarim da Alvorada, que era um de seus anunciantes:

LEIAM O CLARIM D'ALVORADA. O mais perfeito e completo jornal da classe preta no Estado de São Paulo ${ }^{322}$.

A cooperação com o Clarim da Alvorada e a importância do mesmo para o reerguimento da raça negra eram elogiosamente ressaltados pelo Patrocínio:

\begin{abstract}
É assim que contemplo, extasiado, a organisação de um exercito que se adextra para a lucta e consequentemente para a victoria final da campanha, porque este exercito de bravos vae se mobilisando aos poucos, captando soldados daqui e dos outros estados, concentrando-os, disciplinando os com carinhos, dando-lhes uma escola sã e vigorosa, ensinando-os a cumprir com o dever, para a causa a que se propõem a defender.

E esse exercito ora em formação e já em franca actividade, espalhando corneteiros em todos os sectores, que dão o toque de reunir a uma classe desagregada, é o "Clarim d'Alvorada" que tem como chefe supremo a figura symphatica e serena de José Corrêa Leite, moço que tem uma visão larga e reflectida bem formada e que, no entanto, procura esconder as suas bellas qualidades, dentro dum ambiente da mais pura e singela modestia.

É esse moço, seguido de outros, taes como: Jayme d'Aguiar, Henrique A. Cunha, Gervasio de Moraes, Sebastião G. De Castro, Luiz de Souza e outros, accrescido ainda com a figura extraordinaria do grande tribuno prof. Vicente Ferreira, que vem formando esse exercito negro que é o "Clarim d'Alvorada". Digo bem que esse orgam é ou equivale por um grande exercito, porque elle bem luctando contra as idéas um tanto obscuras de centenas de homens pretos, que pela sua quasi completa ignorancia, ainda não cogitaram duma união solida, com um programmade alta relevancia, tanto moral como social, para entrarem na posse dos direitos que lhes cabe na sociedade e na vida do paiz, como brasileiros que são ${ }^{323}$.
\end{abstract}

Promoveu, ainda, um concurso para escolher qual era o rapaz de cor mais simpático da cidade, e exaltou Luiz Gama e o 28 de setembro, o Dia da Mãe Preta.

A atuação do Auriverde e do Patrocínio nos mostra o grau de maturidade da imprensa negra no final da década de 1920, onde constatamos que as reivindicações tornam-se mais candentes e que os negros querem ser reconhecidos como sujeitos da História. Além disso, nos indica a importância do Clarim da Alvorada no cotidiano jornalístico da Capital e de outras regiões do Estado, pela intensa troca de experiências e ideias com outros periódicos.

\footnotetext{
${ }^{321}$ Idem, 23 mar. 1930, anno 4, n. 51, p.2

${ }^{322}$ Idem, ibidem, p.3

${ }^{323}$ O Patrocínio, 19 out. 1930, anno 5, n. 55, p.2
} 
Mais do que uma entidade, as lideranças são reconhecidas em todo o meio afrodescendente, e José Correia Leite e Lino Guedes aparecem como personagens principais.

\section{Progresso}

Entre 23 de junho de 1928 e 15 de novembro de 1931 foi publicado o jornal Progresso, com redação no Largo do Riachuelo, 38 e periodicidade mensal. Podia ser adquirido através de assinaturas semestrais e possuía tipografia própria, onde eram também realizados trabalhos por encomenda. Suas edições alternavam-se entre quatro e oito páginas, dependendo da ocasião.

Argentino Celso Wanderley, já citado, permaneceu como seu diretor e único proprietário até 1929, quando o cedeu a Wanderley \& Ferreira, uma empresa criada por ele em associação com João Batista Ferreira. Lino Guedes juntou-se ao periódico como editor em 1928, seguido pelo diretor Euclydes dos Santos e os gerentes Manoel Conceição e Horácio Cunha. Os principais colaboradores são Luiz Carmillo, Jacob Netto, Euclydes de Oliveira, Benedicto Florêncio, Antônio dos Santos Oliveira, Adalberto Pires de Freitas, Rodolpho de Loremal, João B. Ferraz, João Eugenio da Costa e Arlindo Veiga dos Santos. Possuía representantes nas cidades de Tiête, Limeira, Cosmópolis, Sorocaba, São Vicente, Botucatu, Rio Claro e Uberaba.

Quanto à formatação, apresentava fotografias em todas as edições, em sua maioria, de pessoas homenageadas pelo jornal, além de ilustrações de lugares, do carnaval e de festas.

Uma característica marcante era a publicação de artigos que, de alguma maneira, colocassem em evidência as questões referentes ao preconceito racial, tratando ainda de temas políticos e religiosos, mencionando o respeito, a ética e a moral para a melhoria da conduta pessoal frente à sociedade.

Possuía diversos anúncios que ocupavam normalmente a última página. Havia uma coluna cujo nome era Abolicionista que tomba, na qual trazia algumas homenagens e informações a respeito de pessoas falecidas envolvidas na luta a favor da abolição. Na coluna Sociais eram noticiados casamentos, óbitos, nascimentos, batizados e outros acontecimentos menores. Também publicava notícias sobre associações recreativas e culturais, esportes e atletas negros no cenário esportivo nacional e mundial, como o futebol e o boxe. Contém seções destinadas aos eventos culturais, como: teatro, música, dança, cinema, bailes, carnaval, 
poesia, etc. Eram, além disso, fornecidas informações de vários países a respeito dos negros e dos problemas enfrentados por eles.

O periódico foi fundado como parte das comemorações e divulgação do centenário da morte de Luiz Gama, e Lino Guedes empreendeu uma campanha em prol da construção de uma herma em sua homenagem, como nos mostra o editor em notícia que ocupou quase toda a primeira página da edição $\mathrm{n}$. 20:

Felizmente, continua para o seu fim satisfactorio a idéa que o Progresso lançou de em nome dos pretos do Brasil, enternizar no Bronze os feitos do poeta de Trovas Burlescas.

Luiz Gama, fás jús a essa homenagem que só no primeiro centenario de seu nascimento vae ser feita por aquelles que a sua palavra fulgurosa, sua penna adiamantina, salvou de impiedoso captiveiro.

Não se admira.

Todo brasileiro é assim.

Faz questão de resaltar os valores alheios esquecendo os seus...

Mas o dia que resolve reparar a falta commetida, fala convictamente, com altruismo, como vem acontencendo com o movimento em prol da herma a Luis Gama.

Todas as classes sociais se agitaram, pressurosas em levar um obulo a Commissão, para que assim se desempenhe com mais efficiencia, do que se obrigara: por em distaque um preto para elevar o moral da Raça ${ }^{324}$.

Além da homenagem institucional ao abolicionista, o objetivo era promover a elevação moral dos negros, conduzindo-os ao "caminho do progresso", contestando continuamente a situação dos mesmos em São Paulo. Em alguns momentos, as críticas foram dirigidas aos próprios negros, mas, em geral, dirigiam-se à parcela da sociedade que continuava a discriminá-los. Tal postura era semelhante à adotada por Guedes, Florencio e Moraes quando estiveram à frente do Getulino.

A educação era tema frequente dos artigos, onde o discurso é pragmático e voltado para o trabalho:

\section{CUIDAR DA CRIANÇA É CUIDAR DO FUTURO}

É preciso cuidar com sinceridade e com intelligencia no futuro de nossa mocidade negra e se unam e, dentro da esphera da sua acção, se dediquem à tarefa remuneradora por excellencia, pelo fruto que produzirá no futuro, a salvação da Raça Negra ${ }^{325}$.

\footnotetext{
${ }^{324}$ Progresso, 31 jan. 1930, anno II, n. 20, p1

${ }^{325}$ Progresso, 15 nov. 1931, ano IV, n. 42, p.1
} 
A degradação moral de jovens e idosos, para além do discurso moralista, é constantemente atacada. As moças são a maior preocupação, pela suscetibilidade à prostituição, principalmente pelo comportamento nos salões, fato sempre comentado por todos os números:

Por quasi (sic) todo S. Paulo se depara com grupos de crianças abandonadas a devassidão e ao oprobrio.

Que dizer dos menores que estiolam nos salões?

Corpos tenros e já em farrapos! São flores em botão que jamais darão frutos sazonados, porque vivem sem amparo de ninguem, pelas ruas crestando-se pelos bailes.

Este triste espectáculo não deve continuar, não pode continuar ${ }^{326}$.

Outra característica desse jornal foi a publicação de matérias alusivas a algumas personalidades que participaram do processo de abolição da escravidão no Brasil. Aborda assuntos literários, humorísticos e políticos, nos quais procura manifestar a insatisfação perante as injustiças cometidas contra os negros.

O Progresso combatia firmemente a ideia de inferioridade racial e o preconceito, muitas vezes revelado por estrangeiros, como no episódio envolvendo a apresentação da dançarina Josephine Baker em São Paulo em $1930^{327}$ e o jornal Chileno Las Últimas Noticias, que intitulou o artigo sobre o acontecimento de "Coisas de Negro":

Com a epigraphe acima Las Ultimas Noticias, jornal de Santiago (Chile), sobre a estréa de Josephina Backer, em S. Paulo, inseriu alguns informes eivados de mentiras de todo o porte, e que pareceu forjadas para causar escandalo.

O intuito dos nossos colegas talvez não fosse outro senão apresentar esta capital como o ultimo recanto do mundo, habitado por barbaros.

(...)

As "cousas ( sic) de negro" que tanto escandalizaram os nossos collegas chilenos, se reduzem a pouco, isto é, de suas proporções naturaes, seria indigno da nossa cultura, da nossa tradição de povo essencialmente hospitaleiro e sem eivas de pretensões de côr - seria indigno, repetimos, que recebessemos aqui a "bailarina de ebano" entre assuadas e debaixo de uma chuva de pedras.

Reportemo-nos ao que ocorreu no theatro Sant'anna, quando da estréa de Josephina Backer. Annunciado o espectaculo, aquelle logradouro ficou repleto.

Do programma constavam, além das dansas de Josephina, diversos numeros, executados por outros artistas.

Ao dar a execução aos que não aparecida a dançarina, o povo protestou. Tinha ido ali para asssistir ás danças que fizeram em Paris delirar. O "choro" organizado em S. Paulo que executava musicas interessantes, tocou o Hymno Nacional, a ver se assim continha os protestos. Então, estes recrudesceram. Compreendeu-se logo que os

\footnotetext{
${ }^{326}$ Progresso, 15 nov. 1931, anno IV, n. 42, p.1

${ }^{327}$ Josephine Baker, nome artístico de Freda Josephine McDonald, (Saint Louis, 3 de junho de 1906 — Paris, 12 de Abril de 1975) foi uma dançarina norte-americana, naturalizada francesa em 1937, e conhecida pelos apelidos de Vênus Negra, Pérola Negra e ainda Deusa Crioula. Sobre Josephine Baker, ver JULES-ROSETTE, Bennetta. Josephine Baker in art and life: the icon and the image. University of Illinois Press, 2007.
} 
protestos se levantaram por causa da ausencia de J.B. Levantou-se o panno esta appareceu, dançou, foi muito applaudida.

Terminada esta parte, vejamos o resto. O Publico, que encheu o theatro Sant'anna era "bem" paulista, como affirma o nosso collega. Não era composto dos negros que o perfido "bien" denuncia. Não houve allusões a politicos locaes e o povo não quiz pôr abaixo o theatro. Não houve desrespeito ao chefe de policia e Josephina não deixou de debutar. Estreou e foi muito applaudida.

Em tudo isso, o que é triste, e somos obrigados a confessar, é que os nossos collegas tenham publicado uma nota diabolicamente falsa, em cujas palavras tendenciosas reponta sómente o desejo de amesquinhar o povo de S. Paulo, sempre gentil para com todos os estrangeiros ${ }^{328}$.

A postura nacionalista de Lino Guedes era visível desde os tempos do Getulino. Seus alvos preferidos: os norte-americanos e europeus. Todo mal entendido ou tratamento desigual era tratado como uma ofensa grave a todos os negros brasileiros, como mostra o relato abaixo, de 1931:

O emprezario (sic) José Loureiro organizou um grupo de negros retintos para irem a Europa cantar 'o que é nosso' e dançar 'o coco' do Norte como os sambas e cateretês da nossa gente.

Muito simples, claro e patriotico o que acima leram. Pois jornal houve que achou um tanto fora de nivel racial a escolha de José Loureiro: - deviam ser mestiços os escolhidos! Talvez para que as taes canções e os bailados tivessem mais doçura.

Não sabemos porque essa renitente perseguição ao negro patente do Brasil...

Mais uma cousa (sic) sabemos, e que deve consolar o negro retinto, os mestiços levarão para lá, aos olhos do estrangeiro, a certeza de que no Brasil o negro serviu e ainda serve para tudo até para produzir a legião dos mestiços que dansam (sic) sambas e de que o Brasil se gloria... ${ }^{329}$

Mas é claro que o preconceito não era prerrogativa apenas dos estrangeiros, como se sabe. Em 1928, a exclusão do negro de certos cargos públicos tornava-se cada vez mais evidente e a ação de Julio Prestes, então Presidente do Estado, foi providencial, derrubando a proibição da entrada de negros na Guarda Civil. O deputado Orlando Prado, em sessão da Assembléia Legislativa, comentava a situação:

Os pretos, sr. Presidente, haviam sido sistematicamente afastados dos exercícios de certos cargos na administração pública, tais como os da Guarda Civil, fiscalização de veículos, guarda da Penitenciária e, mesmo na Força Pública, raríssimos têm sido os pretos que conseguem promoção até os postos de sargento.

Aos que estabeleceram esse regime, sr. Presidente, pareceu, quiçá, vergonhoso e antiestético, aparecer aos olhos dos estrangeiros que nos visitam, e que até nos fazem o favor de nos explorar, um Guarda Civil em que se encontrassem homens de cor, formando ao lado de brancos enluvados e não sei mais que raças das puras, das que não têm sangue negro e até têm sangue azul $[\ldots]^{330}$

\footnotetext{
${ }^{328}$ Progresso, 31 jan. 1930, anno II, n. 20, p.1

${ }^{329}$ Progresso, 23 jun. 1931, anno IV, n. 37, p.1

${ }^{330}$ Anais da Câmara dos Deputados de São Paulo, vol. 1, 1928, 13 a Sessão Ordinária em 31 de julho, p. 351,

Apud DOMINGUES, Petronio. Uma história não contada...op.cit., p. 135.
} 
Alguns meses depois, o Progresso ainda faria elogios ao governante de forma bastante ponderada, uma característica peculiar de seu redator de não polemizar sobre medidas do governo:

O gesto do Sr. Julio Prestes, já o dissemos, é desses que merecem os maiores applausos, e nós, que jamais alimentamos o desejo de encontrar mau tudo quanto o governo pratica, não negamos, de nossa parte, os nossos encomios, os mais sinceros, ao illustre sr. presidente do Estado ${ }^{331}$.

O jornal valorizava a perseverança do negro, a liberdade concedida pela Abolição e a sua contribuição para a construção do país:

Ingratos temos sido, para com aquelles que, sob o azorrague de um captiveiro incruento contribuiram bastante para a ordem e para o progresso do Brasil.

A liberdade dada ao preto, depois de uma lucta incessante, não é pagamento ao muito que fês ao paiz.

Com mais vagar, medite quem de direito, e veja si o negro, nesta porção da America, que elle ajudou a formar, é ou não esquecido? ${ }^{332}$

O periódico às vezes escolhia determinado tema e lhe dedicava espaços significativos, como por exemplo, o da situação precária de trabalhadores negros na Capital:

\begin{abstract}
A prova disso temos entre muitos servidores da Limpeza Pública.
(...)

Conhecemos alguns deles: Honorio Gonçalves da Silva, por exemplo, com oitenta annos de idade ainda empurra a sua carrocinha verde e apanha lixo o dia inteiro nas ruas da cidade. Lino Candido, com 90, ainda é um dos trabalhadores mais pontuaes ao serviço. O mais mathusalem deles todos chama-se José Pedro da Silva. (...) Tomou parte na campanha do Paraguay. Dedicou toda a sua vida a lavoura. Foi escravo, da familia do cadete Santos, em Rio Claro, tendo sido liberto com a lei de 13 de maio. Ha dez annos que trabalha na Limpeza Publica. Não lhe foi possivel arranjar outro emprego. ${ }^{333}$
\end{abstract}

Esse jornal mereceu ser destacado por que foi importante veículo de reivindicação em São Paulo, ainda que sobre Lino Guedes pairassem polêmicas e críticas a respeito de seu estilo literário na condução do jornal. Ao lado do Clarim da Alvorada, o jornal consolidou-se em poucos anos como um dos órgãos mais contundentes na preservação dos direitos dos negros em São Paulo no final da década de 1920, em um momento decisivo para o país, que se encaminhava para mudanças políticas significativas, como a decadência das velhas oligarquias escravistas, a lide com os efeitos da crise econômica mundial em 1929, com a consequente perspectiva de dias melhores para os afro descendentes na Capital com um novo Governo.

\footnotetext{
${ }^{331}$ Progresso, 15 nov. 1928, anno I, n.6, p.1

${ }^{332}$ Idem, ibidem, p. 2

${ }^{333}$ Progresso, 31 jan. 1930, anno II, n. 20, p.2
} 


\section{O Centro Cívico Palmares}

O objeto deste estudo é a análise dos jornais da imprensa negra, como dissemos logo de início. No entanto, julgamos procedente e necessário refletirmos a respeito de duas entidades ligadas ao movimento negro das décadas de 1920 e 1930 que influenciaram, com a atuação de seus líderes, a postura jornalística dali em diante, até resultar na completa mudança de estratégia dos movimentos reivindicatórios para a população negra. Uma delas foi o Centro Cívico Palmares.

As fontes mostram que os acontecimentos mais importantes do meio negro eram discutidos em algumas áreas próximas à região mais central da cidade, como o Largo do Riachuelo, a Rua Benjamin Constant, a Rua 15 de Novembro, o Largo do Piques (atual Praça da Bandeira) e as Praças da Sé e João Mendes. Um pouco mais afastado estava o bairro da Barra Funda. as próximas à Praça da Sé, do Largo do Piques (atual Praça da Bandeira). Os locais preferidos para as discussões eram os bares e os cafés, como o Avelino, na Praça João Mendes, e o Pretalhão, na Rua Barão de Paranapiacaba ${ }^{334}$. Havia a proibição do culto africano e as opções de lazer destinadas aos negros eram restritas ${ }^{335}$. Somente as associações de imigrantes estavam aparelhadas para este fim.

Em uma dessas conversas, o grupo formado por José Correia Leite, Gervásio de Moraes, Manoel Antonio dos Santos, Roque dos Santos, Isaltino Veiga dos Santos (que viria a ser o Secretário Geral da Frente Negra Brasileira) recebeu a visita de um sargento da Força Pública de Campinas, chamado Antonio Carlos, já citado em nossa Introdução. Ele veio para São Paulo em 1924, por ocasião do levante tenentista e, ao término do conflito, acompanhou Miguel Costa ao encontro com Luis Carlos Prestes para seguir a marcha da Coluna, retornando em 1926 para São Paulo.

A ideia primeira do grupo era fundar uma biblioteca exclusiva para os negros, onde pudessem promover discussões, melhorar seus conhecimentos ou simplesmente "bater papo".

\footnotetext{
${ }^{334}$ FLOREAL, Silvio. Ronda da meia-noite. São Paulo: Cupolo, 1925, p. 131 Apud DOMINGUES, Petronio. Uma história não contada...op.cit., p. 324.

335 O Código Penal de 1890 estipulava: "Art. 157. Praticar o espiritismo, a magia e seus sortilégios, usar de talismãs e cartomancias para despertar sentimentos de ódios ou amor, inculcar cura de moléstias curáveis ou incuráveis, enfim, para fascinar e subjugar a credulidade pública: Pena: de prisão celular por um a seis meses e multa de $100 \$$ a 500\$000; Art. 158. Ministrar, ou simplesmente prescrever, como meio curativo para uso interno ou externo, e sob qualquer forma preparada, substância de qualquer dos reinos da natureza, fazendo, ou exercendo assim, o ofício do denominado curandeiro: Penas: de prisão celular de seis meses e multa de $100 \$$ a 500\$000. Ver BASTOS, José Tavares. Código Penal Brasileiro de 1890. São Paulo: C. Teixeira \& C., 1918, pp. 96-97.
} 
Ao invés da biblioteca, porém, foi criado o Centro Cívico Palmares (CCP) em 12 de outubro de 1926.

Inicialmente, a sede localizou-se em uma casa alugada no Cambuci, indo em seguida para a Rua Lavapés. O objetivo era agrupar mais os negros para que evitassem a indiferença e as banalidades, deixando de importar-se somente com bailes e festas.

Por ter a militância dos irmãos Arlindo e Isaltino Veiga dos Santos, o Centro Cívico Palmares poderia ser considerado o precursor da Frente Negra Brasileira, afirmação que suscita dúvidas. Havia uma diferença programática: o Palmares era essencialmente uma entidade com fins culturais e educacionais, conforme reza seu estatuto:

$\mathrm{Art}^{\circ} 2^{\circ}$. O fim do CENTRO é zelar pelos interesses dos homens pretos, facilitandolhe instrucção physica, moral e intellectual, manter uma bibliotheca, finalmente incentivar por todos os meios possíveis o gosto pelo aperfeiçoamento do negro, manter cafe, realisar reuniões de socios em sessões semanaes para tratar de assumptos sociaes ou para o exercicio de declamação. Manter Escolas de educação physica, aperfeiçoamento e para analphabetos ${ }^{336}$.

Já a Frente Negra apresentou um programa mais complexo e estruturado, pois além do aspecto cultural, seu estatuto previa assistência profissional, jurídica e financeira, além da criação de cooperativas econômicas, escolas técnicas e de ciências e artes, entre outros empreendimentos. Possuía diretoria, departamentos, corpo social e a presença de um Grande Conselho, cujos detalhes serão analisados mais adiante. Diferia da outra organização principalmente pelo grande viés político que apresentava.

O Centro Cívico Palmares era respeitado pela Igreja Católica, sendo citado em alguns sermões, onde se dizia que "a essência da brancura, a nata do elemento negro [eram] encontrados em Palmares" (Progresso, 23 jun. 1928, n. 1, texto de Vicente Ferreira).

Sua decadência ocorreu por volta de 1929, quando um negro inglês chamado Joe Foyes-Gittens tornou-se presidente e reestruturou a instituição. Também conhecido por "Mr. Gids", dono de uma papelaria chamada Casa Vanorte, era acusado de ditador por alguns militantes e de fazer mau uso das finanças da entidade, o que provocou a dissidência de membros importantes ligados ao movimento negro na época, entre eles os irmãos Veiga dos Santos. O Clarim da Alvorada registrou esse momento nas palavras de Gervasio de Moraes, em artigo "Aos Negros Sensatos de São Paulo":

E para que falleçam os sophismas gratuitos de um certo luctador anonymo, declaro que, o motivo real da minha retirada daquelle Centro, justifica-se simplesmente com

\footnotetext{
${ }^{336}$ Estatuto do Centro Cívico Palmares, disponível no Arquivo do Estado de São Paulo sob registro civil n. 1304, de 28 de dezembro de 1926, $1^{\circ}$ Cartório de Registro de Títulos da Capital.
} 
a nova imposição de absolutismo doado pela maioria em Assembléa do actual presidente, Mister Joe Fayes Gittens ${ }^{337}$.

Os problemas no Centro Cívico Palmares também são apontados por outro colaborador na "Seção Livre":

\begin{abstract}
AOS DIRECTORES DO C.C. PALMARES
Para que não continue as mesquinharias que estão sendo propaladas, em torno do meu nome: - lanço por este meio, um desafio de honra, aos netunos dirigentes do centro acima e sobre tudo, ao sr. Fayes Gittens (o famoso dictador) para bem alto provarem que, de facto me retirei daquelle centro, sem as devidas prestações de contas.

Durante o tempo que occupei o cargo de cobrador daquelle centro de cultura, sempre prestei contas, tão sómente dos meus actos, como também do meu mandato. (João Lucio Affarez $)^{338}$
\end{abstract}

As críticas ao presidente do CCP pareciam ser unanimidade. Argentino Celso Wanderley era um dos dissidentes, e suas críticas à conduta do dirigente eram também registradas nas páginas do Progresso, como nos relata Kim Butler, que também pesquisou o movimento e os jornais negros em São Paulo:

[Argentino] Wanderley resigned from Palmares' management committee (comissão de syndicancia) in August, and by late 1928 Progresso had become openly critical of Palmares' leadership. When Joe Foyes-Gittens ran for re-election as Palmares's president in December, Progresso expressed concern over the future direction of the organization. "If one looks at the initial plan, there is much that the Centro [Cívico Palmares) has placed on the list of forgotten things" 339

A autora encontrou em suas pesquisas informações sobre valores não contabilizados pela entidade, o que indicaria desvio de dinheiro. Pelo visto, houve controvérsias sobre a prestação de contas, já registradas pelas páginas do Progresso linhas atrás:

The journal published the October budget, which showed a "disappearance" of $111 \$ 400$ milréis in addition to a deficit of $44 \$ 900$ milréis, which remained unaccounted for as late as the following January. ${ }^{340}$

Parece não existir dúvidas sobre as polêmicas decorrentes da gestão do Centro Cívico Palmares, que levaram à sua decadência e dissolução. A principal contribuição, a nosso ver, foi ter consolidado a atuação de diversas lideranças no meio negro, como Gervásio de Moraes, Argentino Wanderley, José Correia Leite e os irmãos Veiga Santos, estes últimos ativos participantes na fundação da Frente Negra Brasileira, como veremos a seguir.

\footnotetext{
${ }^{337}$ O Clarim da Alvorada, 3 fev 1929, p.4.

${ }^{338}$ Idem, ibidem, p.3

${ }^{339}$ BUTLER, Kim. Freedoms given, freedoms won: Afro-Brazilians in post-abolition, São Paulo and Salvador ACLS Humanities, Latin American studies: Rutgers University Press, 1998, p. 105.

${ }^{340}$ Idem, ibidem.
} 


\title{
4.2. A criação da Frente Negra Brasileira e A Voz da Raça
}

Outro jornal a ser registrado em nossa Dissertação é $A$ Voz da Raça, cujo subtítulo, Orgam Oficial da Frente Negra Brasileira, identificava-o como único porta-voz desta. Dessa forma, entendemos ser necessário conhecer um pouco mais sobre a entidade que ele representa, sobretudo em seus aspectos ideológicos ${ }^{341}$.

A dissidência do Centro Cívico Palmares provocou efeitos diversos junto às lideranças negras em São Paulo. Algumas eram conhecidas e tinham sua posição já estabelecida junto às associações e outros periódicos negros. Era o caso de José Correia Leite, Lino Guedes, Argentino Wanderley e Gervasio de Moraes. Outras estavam am ascensão, como Arlindo Veiga dos Santos e seu irmão, Isaltino:

\begin{abstract}
As esperanças criadas em torno do C.C. Palmares, como um espaço de transformação do negro através da educação e instrução, foram centrais para se pensar os moldes da organização da FNB. O seu fechamento marcou todo o grupo de envolvidos em sua liderança, muitos deles futuros dirigentes da FNB. A associação, portanto, era uma figura central na história dos movimentos negros paulistanos. ${ }^{342}$
\end{abstract}

É provável que o fracasso na realização do Congresso da Mocidade Negra, que teve em Arlindo um de seus principais incentivadores, e a Revolução de 30 tenham influenciado a criação da Frente Negra Brasileira ${ }^{343}$, mas essa possibilidade carece de uma análise mais aprofundada e de novas pesquisas.

Surgindo em 16 de setembro de 1931, desde logo apoiou o governo Vargas e por isso, numa época em que autoritarismo, militarismo e anti-comunismo estavam frequentemente presentes na pauta de discussões da sociedade, era acusada de nacionalista e autoritária. Baseada na existência de um Grande Conselho e da obediência cega ao Chefe, foi principalmente considerada uma organização fascista.

Seu estatuto incorporava, como já referido, o interesse político nos própositos de sua atuação, deixando definitivamente o caráter puramente recreativo e beneficente que caracterizara outras associações em prol da raça negra:

\footnotetext{
${ }^{341}$ Para saber mais sobre a criação e atuação da Frente Negra Brasileira, ver OLIVEIRA, André Côrtes. Quem é a Gente Negra Nacional?...e OLIVEIRA, Laiana Lannes. Frente Negra Brasileira: Política..., dissertações de mestrado, op.cit.

${ }^{342}$ PINTO, Regina Pahim. O movimento negro em São Paulo... p. 89 Apud OLIVEIRA, André Côrtes. Quem é a Gente Negra...op.cit., p. 73

${ }^{343}$ O termo "frente" era bastante usado na época, a exemplo da Frente Única Paulista, que uniu o PRP (Partido Republicano Paulista) ao Partido Democrático. Ver SIQUEIRA, José Jorge. op.cit, p. 83 e
} 
Art. $1^{\circ}$ - Fica fundada nesta cidade de São Paulo, para se irradiar por todo o Brasil, a FRENTE NEGRA BRASILEIRA, união política e social da Gente Negra Nacional, para afirmação dos direitos históricos da mesma, em virtude da sua atividade material e moral no passado e para reivindicação de seus direitos sociais e políticos, atuais, na Comunhão Brasileira.

A intenção política é claramente exposta:

Art. 4o - Como força política organizada, a "FRENTE NEGRA BRASILEIRA", para mais perfeitamente alcançar os seus fins sociais, pleiteara, dentro da ordem legal instituída ao Brasil, os cargos eletivos de representação da Gente Negra Brasileira, efetivando a sua ação político-social em sentido rigorosamente brasileiro.

Desde logo, a instituição estabelecia as bases de seu programa, que era o de arregimentar o maior número de membros, pois somente assim os objetivos de valorização e cidadania do negro seriam alcançados. Conforme o artigo $2^{\circ}$, poderiam "pertencer à "FRENTE NEGRA BRASILEIRA" todos os membros da Gente Negra Brasileira de ambos os sexos, uma vez capazes, segundo a lei básica nacional.

Era o mesmo programa de tantas outras associações e jornais: a elevação moral e intelectual do negro, porém rezava específica e objetivamente como isso seria realizado:

Art. 3o - A "FRENTE NEGRA BRASILEIRA", como força social, visa a elevação moral, intelectual, artística, técnica, profissional e física; assistência, proteção e defesa social, jurídica, econômica e do trabalho da Gente Negra.

$\S$ Único - Para execução do art. 3o, criará cooperativas econômicas, escolas técnicas e de ciências e artes, e campos de esportes dentro de uma finalidade rigorosamente brasileira.

$\mathrm{O}$ artigo $5^{\circ}$ determinava que...

Art. $5^{\circ}$ - Todos os meios legais de organização necessários à consecução dos fins da FRENTE NEGRA BRASILEIRA serão distribuídos em tantos departamentos de ação quantos forem precisos constando no regulamento especial.

Os artigos $6^{\circ}$ ao $10^{\circ}$ tratavam a forma como a FNB seria dirigida:

Art. $6^{\circ}$ - A FRENTE NEGRA BRASILEIRA é dirigida por um GRANDE CONSELHO, soberano e responsável, constando de 20 membros, estabelecendo-se dentro dele o Chefe e o Secretário, sendo outros cargos necessários preenchidos a critério do Presidente. Este Conselho é ajudado em sua gestão pelo Conselho Auxiliar, formados pelos cabos distritais da Capital.

Art. $7^{\circ}$ - O Presidente da FRENTE NEGRA BRASILEIRA é a máxima autoridade e o supremo representante da FRENTE NEGRA BRASILEIRA, e a sua ação se limita pelos princípios que a orientam.

Art. $8^{\circ}$ - A FRENTE NEGRA BRASILEIRA representa-se ativa e passivamente, judicial e extra-judicialmente pelo GRANDE CONSELHO, na pessoa do Presidente e, na falta deste, por um dos outros diretores. Os membros não respondem, subsidiariamente, pelas obrigações sociais.

Art. $9^{\circ}$ - Têm força de lei os regulamentos, ordens, avisos e comunicações emanadas pelo GRANDE CONSELHO, e os casos omissos nestes Estatutos serão regidos pelas leis e praxes em vigor no País.

Art. $10^{\circ}$ - A FRENTE NEGRA BRASILEIRA somente se extinguirá pela vontade unânime do GRANDE CONSELHO e da maioria do Conselho Auxiliar e de todos sócios reunidos na Assembléia Geral Especial, convocada pelo Presidente Geral, em 
harmonia com o GRANDE CONSELHO. Se por acaso, for extinta, seus bens passarão para uma Sociedade Beneficente de Gente Negra, que se mostrar digna da doação.

Estes estatutos são irreformáveis nos artigos $1^{\circ}, 2^{\circ}, 6^{\circ}$ e $7^{\circ}$, a não ser por vontade unânime dos Conselheiros. ${ }^{344}$

As sucessivas menções ao Grande Conselho e à concentração de poder nas mãos do Presidente Geral fizeram com que a FNB fosse frequentemente acusada de fascista, dado que, "inspirados nas ideias rascistas do fascismo europeu, os irmãos negros Veiga dos Santos alimentaram a ideia de um contra-racismo, antibranco". 345

Arlindo Veiga dos Santos (o Chefe do Grande Conselho), antes de fundar e dirigir a Frente Negra, participou, em 1928, da fundação do Pátria-Nova (Centro Monarquista de Cultura Social e Política), embrião da AIPB (Ação Imperial Patrianovista Brasileira) ${ }^{346}$. Os integrantes do movimento patrioanovista participaram da fundação da AIB (Ação Integralista Brasileira) em 1932, quando esta ainda não havia assumido abertamente o caráter fascista de suas ações. $^{347}$

Atendendo seu estatuto, a Frente Negra implantou internamente uma disciplina bastante rígida e uma unidade de comando, onde ninguém discutia ou questionava o poder do chefe. José Correia Leite relata em sua biografia que manteve os laços de amizade com exintegrantes da Frente Negra depois de seu desligamento da entidade, em 1932, e os mesmos demonstravam posturas muito diversas das apresentadas quando militantes daquela organização. Alguns até mesmo reconheceram estar equivocados anteriormente.

A FNB tentava manter uma aparência de neutralidade em relação às ações do governo, não fazendo menções diretas a dirigentes e a seus atos. Existia, inclusive uma ordem expressa para não se discutir assuntos relativos à política governista nos ambientes da entidade ${ }^{348}$.

O fato de Arlindo Veiga ser membro do movimento patrianovista e "chefe supremo" do Conselho da FNB levava seus admiradores (e também os detratores) a confundí-los, o que

\footnotetext{
${ }^{344}$ Os estatutos da FNB foram publicados no Diário Oficial em 4 de novembro de 1931

345 CARNEIRO, Maria Luiza Tucci e KOSSOY, Boris. A imprensa confiscada pelo DEOPS (1924-1954). Volume 1. Série Labirintos da Memória. São Paulo: Atelie Editorial, 2003, p. 52

${ }^{346} \mathrm{O}$ patrianovismo foi um movimento político nacionalista, antiesquerdista e anti-republicano, na medida em que defendia a volta da monarquia ao país. No meio negro, o principal divulgador era Arlindo Veiga dos Santos. Para saber mais sobre Patrianovismo, ver ROY, Teresa Maria Malatian. A ação imperial patrianovista brasileira. Dissertação de Mestrado. São Paulo: PUC-SP, 1978.

${ }^{347} \mathrm{Na}$ verdade, em todos os depoimentos analisados junto às fontes, nenhum dos entrevistados (Aristides Barbosa, Francisco Lucrécio, Marcello Orlando ou Pedro Paulo Barbosa) assumiram o caráter fascista dentro da Frente Negra Brasileira, apesar do radicalismo de alguns de seus artigos revelarem claramente essa tendência.

${ }^{348}$ Essa ordem caiu em desuso a partir de 1935, pois a Frente tornou-se partido político, altamente influenciada pela possível candidatura de Arlindo Veiga.
} 
não era muito favorável à Frente, uma vez que dependiam de quantidades cada vez maiores de filiados e sucursais nas mais diferentes regiões.

Terminada a Revolução de 32, a Frente se sentia fortalecida pelo apoio prestado a Vargas. O secretário Isaltino Veiga dos Santos viajou ao Rio de Janeiro às expensas da Frente para uma audiência com o presidente, porém voltou de lá sem nada de concreto ou positivo. Segundo Correia Leite em suas memórias, esse teria sido o principal motivo de Isaltino desligar-se da Frente.

Apesar dos conflitos e das divergências com os irmãos Veiga Santos, José Correia Leite reconhecia em Isaltino o caráter batalhador da pessoa que tinha iniciativa para lutar em prol do negro, apesar de nem sempre ter escolhido o melhor caminho.

A Frente Negra começou a apresentar uma postura mais político-partidária após as saídas de Isaltino, em 1933, e de Arlindo, em 1934, por ocasião de sua candidatura à Constituinte. No lugar deste, assumiu Justiniano Costa, que gozava de prestígio entre os membros da comunidade negra, inclusive tinha a aprovação e simpatia de Correia Leite. Francisco Lucrécio era o secretário.

Porém, os anos que se seguiram dificultaram a atuação da FNB. A ameaça comunista de 1935 torna-a suspeita por sua frequente associação com práticas militares e em 1937, o Estado Novo a fecha sob a alegação de estar registrada como partido político desde 1935 . No entanto, alguns integrantes, entre eles Francisco Lucrécio, refletiram posteriormente e chegaram à conclusão de que a Frente poderia ter continuado como Centro Social, Esportivo e Cultural. Bastava retirar o termo "político" de seu estatuto, e lhe seria permitido operar.

\section{A Voz da Raça}

É importante relembrar que a Frente se expressou constatemente através de $A$ Voz da Raça, jornal criado em 18 de março de 1933 como orgam oficial da Frente Negra, com o objetivo de divulgar os seus ideais. Deocleciano Nascimento, conhecido militante de outros jornais, já citado, foi o primeiro redator e Pedro Paulo Barbosa era o secretário. A redação situava-se inicialmente à Rua Conselheiro Brotero, 156, "propriedade de uma S/A em organisação (sic)".

Jornal combativo, mantido com auxílio da Frente Negra e dos anunciantes, com publicações em Angola e Estados Unidos, alcançou tiragens entre 1.000 e 5.000 exemplares e era impresso nas oficinas Mariano, mediante contrato. 
Inicialmente semanal, a partir do número 18 passou a ser quinzenal, e em 1935, mensal. Composto de quatro páginas, publicava poucos anúncios e era vendido através de assinaturas semestrais e anuais, podendo ainda ser comprado de forma avulsa. O número atrasado era vendido pelo dobro do preço.

A partir da sua edição número 36, de 28 de abril de 1934, seu subtítulo passa a ser Orgam da Gente Negra Brasileira. Servia como principal veículo de comunicação de seus conselheiros e redatores, principalmente Arlindo Veiga, Francisco Lucrécio, Raul Joviano do Amaral e Pedro Paulo Barbosa. Além disso, publicava balanços de contas, comunicados, atividades de seu departamento de música, saúde, biblioteca, etc.

As páginas $A$ Voz da Raça ratificavam a estrutura da FNB, que

... estava constituída de departamentos que procuravam suprir as necessidades do grupo negro. Os serviços e cursos eram gratuitos; a organização mantinha barbearia, gabinete dentário, escola primária com professoras nomeadas pelo Estado, aulas de música, consultório médico dirigido pelo dr. Ferreira Dias, aulas de costura, conjunto regional, comissão de festas, curso de alfabetização de adultos, teatro da Frente Negra, teatro infantil, banda, além do hino e da bandeira. Esta última, com quatro cores, simbolizava o português (cor branca), o índio (cor vermelha), o africano (cor preta) e o verde, em forma de palmeira, representando a Guerra de Palmares. ${ }^{349}$

O primeiro exemplar divulgou um bem elaborado balanço patrimonial da FNB, abrangendo o período entre outubro de 1931 a setembro de 1932:

Em cumprimento ás atribuições que nos são conferidas, na qualidade de Membros da Comissão de Contas, e depois de meticuloso exame dos documentos apresentados pelo snr. Tesoureiro, referentes ao período decorrido de Outubro de 1931 a Setembro de 1932, os quaes foram cuidadosamente controlados com as respectivas faturas e reputados certos, submetemos á apreciação do Grande Conselho o quadro demonstrativo das Receitas e Despezas correspondentes ao supra citado período: $(\ldots)^{350}$

O tesoureiro era Justiniano Costa, que viria a ser o presidente da FNB, e Deocleciano Nascimento que, além de redator, era conhecido guarda-livros, como anteriormente mencionado.

Num rápido exame das principais contas, é fácil imaginar por que a prestação delas em entidades mais complexas e organizadas, como o Centro Cívico Palmares e a Frente Negra Brasil, era alvo de polêmicas sobre uso indevido do dinheiro ou apropriação indébita, pois os números demonstravam crescimento rápido e capacidade patrimonial significativa:

\footnotetext{
${ }^{349}$ A Voz da Raça, agosto de 1936, n. 56, p.1

${ }^{350}$ A Voz da Raça, 18 mar. 1933, anno I, n. 1, p.1.
} 


\begin{tabular}{|l|r|c|c|}
\hline Contas & $\mathbf{3 0 / 0 9 / 1 9 3 2} *$ & $\mathbf{3 1} / \mathbf{1 2} / \mathbf{1 9 3 3}$ & $\mathbf{\%}$ \\
\hline Ativos & $10: 023 \$ 815$ & $24: 590 \$ 400$ & $145 \%$ \\
\hline Patrimônio Social & $1: 710 \$ 015$ & $12: 011 \$ 500$ & $602 \%$ \\
\hline Receitas Totais & $30: 867 \$ 700$ & $50: 827 \$ 100$ & $65 \%$ \\
\hline
\end{tabular}

Em 30 de setembro de 1932, o total de ativos da entidade superava 10 contos de réis, o patrimônio social 1 conto e 700 mil réis e somente as receitas com mensalidades, que correspondiam a $49 \%$ do total, somavam mais de 15 contos apenas nos primeiros nove meses daquele ano. As demais receitas referiam-se a ganhos e donativos com festivais, aluguéis e empréstimos, totalizando quase 31 contos.

Além disso, os números obtidos em março de 1934, referentes ao exercício findo em dezembro de 1933, comprovam o crescimento da FNB: o total de ativos registrara crescimento de $145 \%$, passando a mais de 24 contos de réis; o patrimônio social foi multiplicado por sete, alcançando a cifra de mais de 12 contos e as receitas totais passaram de 30 contos e 867 mil réis em 1932 para 50 contos e 800 mil réis. As receitas com mensalidades correspondiam a $43 \%$ do total de receitas, seguida pelos ganhos com festivais, que correspondiam a $26 \%$.

Como já foi dito, houve suspeita de desvio no Centro Cívico Palmares, e na Frente Negra Brasileira não foi diferente. Em depoimento a Márcio Barbosa, já citado, Placidino Damaceno Motta, um integrante da Frente Negra Brasileira na sua fase final, relatou alguns dos problemas relativos à administração financeira da entidade. $\mathrm{O}$ episódio começou com a tentativa de se organizar uma biblioteca dentro da FNB, que já atravessava situação financeira instável e não destinava os mesmos recursos de antes para os departamentos:

Então se passaram dois meses, o João de Souza [secretário da FNB] e o Justiniano [presidente da FNB após a saída de Arlindo Veiga] me chamaram e disseram: "Tem uma biblioteca aí criada por vocês", e eu: "Tem, a professora criou a biblioteca". Aí eles falaram: "O senhor é o tesoureiro?" Eu falei: "Sou, mas se o senhor quiser pode ficar, eu não entendo muito disso, não.". Eles disseram: "É, porque aqui só pode existir uma tesouraria...Então, tem que dar o dinheiro que é da biblioteca pra tesouraria". Quer dizer, viram o dinheiro, já vieram pra cima...

Eu frequentei a Frente Negra até quando eles se mudaram pra rua Conde de São Joaquim. Ali, um dia abria, o outro dia não abria. Quer dizer o Raul Joviano do Amaral foi que pegou o negócio, mas eles já pegaram minado, não estavam bem financeiramente, não puderam aguentar, os sócios se afastaram.

(...)

Uma sociedade é como um time de futebol. Você tem uma ideia, o sujeito tem outra; o sujeito acha que o presidente não está trabalhando de acordo, mas às vezes não quer comentar para não entrar em atrito, de forma que eu frequentava lá, achava bom, mas acho que eles tiveram o erro de não trabalhar direito. Quer dizer, você está vendo que a sociedade está indo pro vinagre, você ainda vai lá e tira...Isso quem comentou foi o próprio Raul. O roubo. Quando foram procurar o saldo que se dizia 
existir, ficaram desesperados. Procuraram em todo lugar e não encontraram dinheiro algum. Não havia nada. E quem é que foi? Quem podia mexer naquilo? ${ }^{351}$

Pensamos que as representativas dissensões dos irmãos Veiga Santos e a manutenção do comando centralizado podem ter significado o agravamento das dificuldades na administração da FNB antes da dissolução em 1937.

Quanto à divulgação do jornal, é importante dizer que as primeiras manifestações sobre a Frente Negra foram veiculadas ainda no Clarim da Alvorada antes da FNB utilizar $A$ Voz da Raça como seu único porta-voz ${ }^{352}$. O texto de José Correia Leite na edição de 13 de maio de 1929 já anunciava a intenção de uma única organização para tratar a questão do negro:

Os negros de S. Paulo, devem formar a sua frente única: o trabalhar com lealdade para a unificação da classe, antes que seja tarde, pois nós os dirigentes desta folha, não tememos as criticas gratuitas dos innumeros despeitados; porque, enquanto os nossos irmãos de sangue que possuem dois vintens, assistem o retrocesso da raça, fugindo de sua propria sombra, nós temos certeza que, a nossa iniciativa, não perecerá em nossa mente...Ella viveu e vivera latente se vindo de alicerce e gaudio para uma alvorada nova, à geração que há de vir, porque é para ella que estamos plantando este orvalho immenso que tem de florescer - formando negros instruidos - para a maior grandeza do Brasil $^{353}$.

Como já foi dito, o Centro Cívico Palmares inspirou alguns de seus fundadores, que relembravam sua militância agora nas páginas do periódico, bem como os motivos que os levaram à sua dissidência:

(...) porque já estava decepcionado com a queda do C.C. Palmares, donde eu me havia retirado, tão simplesmente por discordar com um estrangeiro na presidência, onde continuei como Palmarino, até que infelizmente desapareceu, devendo-se esse desaparecimento aos próprios negros.

(...)

eu não culpo os meus irmãos negros que são meus inimigos gratuitos, eu não os odeio, quero os sempre, mesmo porque tudo isso não é mais do que o trabalho do maquiavelismo do branco escravocrata, que criou para o negro essa mentalidade, afim de que ele, que sempre foi o Gigante que dormia nunca despertasse. ${ }^{354}$

Arlindo Veiga lembra a importância da obra iniciada pelo Palmares, mas indica que o caminho a seguir será a luta do negro contra ele mesmo e contra aqueles que obstruam o seu desenvolvimento moral e intelectual.

\footnotetext{
${ }^{351}$ Depoimento de Placidino Damaceno Motta a Márcio Barbosa em Frente Negra Brasileira...pp.106-108

${ }^{352}$ Ver neste trabalho o artigo de Frederico Baptista: “O negro deve ser político?” em O Clarim da Alvorada, edição de 1 de julho de 1928, nota de rodapé n. 304.

${ }^{353}$ O Clarim da Alvorada, 13 mai. 1929, ano VI, n. 16, p.1

${ }^{354}$ Isaltino Veiga dos Santos, A Verdade é esta, IN: A Voz da Raça, 1 abr. 1933, n. 3, p.1.
} 
[O Centro Cívico Palmares] obra gigantesca que vamos levando por diante, e da qual (é mister que se diga!) o maior inimigo, até agora, tem sido o próprio negro, com a sua indisciplina, com a sua facilidade de ser embrulhado por brancos indignos, com a sua má vontade contra todas as superioridades intelectuais e morais. ${ }^{355}$

Arlindo nutria simpatia por algumas ideias de Plinio Salgado, possibilitando-lhe a publicação de vários artigos em $A$ Voz da Raça, como o que vemos a seguir:

O Brasil está devendo até a raiz dos cabelos. O Brasil está em vinte naçõesinhas petulantes que não respeitam a Grande Nação.

O Brasil está repleto de companhias, sindicatos, bancos estrangeiros que lhe desceram as entranhas. $\mathrm{O}$ Brasil tem na barriga uma flora de partidos imorais. $\mathrm{O}$ Brasil sofre a sarna de uma imprensa escandalosa, quase toda vendida a grupos de panelinhas. O Brasil está atacado de grangrenas comunistas. O Brasil está deformado, feio, triste, gafaento. Sempre deitado, até o Hino Nacional.

Um gigante "deitado eternamente em berço esplêndido". Ridículo.

Alerta!Alerta!Alerta!Mocidade da Pátria.

De pé, Moços!

Entremos violentamente na história!

Salvemos o Brasil! ${ }^{356}$

A valorização do negro frentenegrino é, acima de tudo, a valorização do negro brasileiro. Até as cores da bandeira da FNB foram pensadas nessa temática, relembrando a composição da nacionalidade através das três raças. Em artigo de agost de 1936, o então presidente Justiniano Costa detalhava o motivo das cores frentenegrinas:

Eis pois, os significados do "quadricolor", já glorioso, bandeira símbolo da Raça Negra Brasileira.

O branco representa o português, que, foi o primeiro colonizador desta parte do Globo; o vermelho, representa a terra do Brasil, os silvícolas, os índios, os primeiros habitantes desta região; o preto, representa, o negro, que transportado para estas plagas, aqui se aclimatou perfeitamente bem, que chegou a esquecer a sua terra de origem, por só pensar neste grande torrão.

(...)

O verde, representa (em forma de Palmeira) aquela arrancada formidável da concentração de negros na Serra da Barriga, como protesto contra a escravidão em que viviam, proclamando a república de "Palmares".357

O tema de volta à África era pouco abordado nas páginas do jornal, porque a FNB e seus líderes entendiam que o negro brasileiro tinha temas muito mais prementes para tratar e deveriam buscar sua afirmação, como nos relata Francisco Lucrécio, secretário da entidade:

\footnotetext{
355 A Voz da Raça, 29 abr. 1933, n.7, p.4, Apud OLIVEIRA, André Côrtes. Quem é a Gente Negra?...op.cit., p. 75.

${ }^{356}$ A Voz da Raça, 26 mai. 1934, n. 38, p.1

${ }^{357}$ A Voz da Raça, agosto de 1936, n. 56, p.1
} 


\begin{abstract}
Na Frente Negra não tinha essa discussão de volta à África. Tínhamos correspondência com Angola, conhecíamos o movimento de Marcus Garvey, mas não concordávamos. Nós sempre nos afirmamos como brasileiros e assim nos posicionávamos, com o pensamento de que os nossos antepassados trabalharam no Brasil, se sacrificaram, lutaram desde Zumbi de Palmares aos abolicionistas negros, então não queríamos, nos afirmaríamos, sim, como brasileiros. Não queríamos perder nossa identidade de brasileiros. Seguimos, portanto, a linha dos nossos antepassados. $^{358}$
\end{abstract}

De início, a questão política é colocada em segundo plano como instrumento para o alcance dos objetivos da FNB. Existe um crítica implícita ao Governo, que beneficiaria o imigrante em São Paulo em detrimento de soluções que beneficiassem o elemento nacional, entre eles o negro. Portanto, o caminho é a ação através da educação, porém nos moldes frentenegrinos:

\title{
EM MARCHA
}

Em face da situação, mais fácil de sentir dentro do cosmopolitanismo de São Paulo, onde há sempre, junto ao maior bem, o maior mal dentro do País, nasceu a FNB visando resolver o problema que por dois métodos talvez nenhum branco ainda compreendera: o método político e o método social.

Feitas as primeiras experiências, passou o método político para o segundo plano. Tática de resolução. Depois de em-vão esperar que se manifestassem, por atos concretos, consciências negras ou mestiças pacientes, a favor da vigente obra iniciada, depois de esperar em balde que os poderes competentes dessem fé da patriótica obra nacionalista iniciada, recorremos ao segundo processo: a EDUCAÇÃO, A FORMAÇÃO dos valores novos segundo a Escola Frentenegrina. (Arlindo Veiga Santos) $^{359}$

Arlindo Veiga, por muitas vezes, ve com pessimismo e desencanto o discurso político da sociedade dominante, e entende que o caminho a seguir é o da ação. O negro deve ser dono de seu destino e tomar para si seu lugar de direito. Na verdade, é um apelo mais incisivo à conscientização e à valorização do elemento nacional:

\section{QUE O NEGRO NÃO SE ILUDA}

O negro precisa entrar violenta e tenazmente na HISTORIA DO PRESENTE DO BRASIL, conquistar violentamente o SEU LUGAR na comunidade nacional, porque - desengana-se! - ninguém lh'o dará por bem. No fim de todos os nossos trabalhos sempre nos quererão tapear, embrulhar, roubar... e felizes de nós ainda, quando o que devia ser nosso fica nas mãos de patrícios brancos e não vae parar nas de estrangeiros! $!^{360}$

A educação escolar e religiosa é vista como a base para transformar a situação do afro descendente no Brasil, visto que seu estado de exclusão ter se dado pela opressão a que foi submetido e não por uma inferioridade natural. O lema da Frente Negra Brasileira, estampado

\footnotetext{
${ }^{358}$ Entrevista de Francisco Lucrécio IN: BARBOSA, Márcio, Frente Negra Brasileira...op.cit., p. 46.

${ }^{359}$ A Voz da Raça, 3 jun. 1933, n. 11, p.1.

${ }^{360}$ A Voz da Raça, 15 dez. 1934, n. 43, p.1
} 
ao lado do cabeçalho do periódico - DEUS, PATRIA, RAÇA E FAMÍLIA - resume a postura a ser seguida pelos frentenegrinos para sua elevação moral e intelectual ${ }^{361}$ :

\section{DELIRIO DA COVARDIA}

O negro precisa de ambiente, mas de um ambiente puro e sádio, de escolas doutrinárias, de viver respirando o ar puro e ameno dos jardins, de uma atmosfera leve, e não a ar pezado e viciado dos porões.

Precisamos pois, como disse um grande publicista: Formar a família pelo casamento, a propriedade pelo pecúlio, a moral pela religião, a inteligência pela instrução. (PEDRO PAULO BARBOSA) ${ }^{362}$

Como já dito, a principal luta da FNB era a do "preto contra o preto", ou seja, o combate aos males internos que prejudicavam o desenvolvimento da raça. Entretanto, essas ameças eram muitas vezes personificadas em integrantes do próprio meio, a quem chamavam de "judas da raça". Em 1933, os embates ideológicos entre os membro da Frente e do Clarim estavam mais que evidentes, apesar dos ataques nunca mencionarem os nomes de José Correia Leite ou daqueles a ele ligados:

\section{ALERTA}

Frentenegrino!

Estamos em plena luta.

Gostamos desses momentos épicos quando as forças do mal se desencadeiam, quando os instintos baixos da escória e da plebe se manifestam, quando o cinismo, a hipocrisia, a infâmia, a canalhice, a estupidez, a sórdida mentira, o ódio e a inveja, os planos inconfessáveis se revelam para destruir os baluartes da verdade e do bem.

(...)

A nossa infeliz Gente Negra Brasileira, tão infeliz que tem por maiores inimigos muitos dos seus próprios membros, cujo egoísmo, cujo instinto reles e desejosos de ruínas de valores, quer atacar toda hierarquia, toda superioridade moral ou mental, para nivelar tudo numa democracia de bobagem, falida em todo o mundo, mas que alguns primitivos idiotas pensam que é a coisa mais atual, mais "viva", sobre a superfície da terra.

(...)

Somos nacionalistas intolerantes e repelimos, e repeliremos sempre quem quer que vier com doutrinas exóticas corromper, com o espírito de luta de classes e de ataque à propriedade a mentalidade dos frentenegrinos. (Arlindo Veiga Santos) ${ }^{363}$

É possível que essas criticas fossem mesmos direcionadas a Leite, que se declarava "socialista"e, portanto, seria tratado como "inimigo da pátria" por Arlindo. Outro alvo da

${ }^{361}$ Como opina Maria Tucci Carneiro, "Arlindo Veiga dos Santos tornou-se conhecido por sua posição nacionalista e monarquista que influenciou a muitos dos membros daquela organização. Por esta razão, o ideário deste órgão emergiu, de início, marcado por slogans que o identificavam com movimentos de extrema direita dentre os quais os integralistas e nazistas. Tanto assim, que o jornal A Voz da Raça trazia como apelo a expressão 'Deus, Pátria, Raça e Família', inspirado no Deus, Pátria e Família, sustentado pela Ação Integralista Brasileira que, desde sua fundação em 1932, saiu em busca de adeptos". VER CARNEIRO, Maria Luiza Tucci e KOSSOY, Boris. A imprensa confiscada pelo DEOPS...op.cit., pp.51-52

${ }^{362}$ A Voz da Raça, 22 abr. 1933, n. 6, p.3.

${ }^{363}$ A Voz da Raça, 1 abr. 1933, n.3, p.1. 
FNB seria Joaquim Guaraná de Santana, expulso da entidade após desavenças com o seu dirigente supremo ${ }^{364}$ :

\section{DIGNIDADE}

Entretanto, alguém, cujo nome deixamos de consignar porque seria mancha a estas colunas, esta indignado e no seu desespero tenta lançar à lama da sua miséria a figura alibada do chefe da F.N.B.

Coitado, merece pena. A sua miséria moral é tão grande que merece compaixão dos fortes."

(...)

"E ele se prestara a esse papel sórdido e imundo porque em tempos dentro da F.N.B., Arlindo Veiga dos Santos, com a luz viva da verdade o obrigou a andar mais ou menos na trilha honesta e como esse transviado não se emendasse, Arlindo vasculhou-lhe todas as misérias e expulsou-o da F.N.B. antes que ele, arruinasse a obra de todos os negros do Brasil. (Peixoto) ${ }^{365}$

Havia a preocupação em não associar as ações de Arlindo Veiga dentro da FNB às suas ligações com o movimento patrianovista, pois isso implicaria uma ameaça à ordem social:

É verdade e, o Brasil inteiro sabe, que o Dr. Arlindo Veiga dos Santos, é o Chefe do movimento patrianovista no Brasil, porém, dentro da F.N.B., onde é presidente geral, é somente negro e nada mais, conforme declaração dele próprio na imprensa de todo o Brasil. ${ }^{366}$

Nas páginas de $A$ Voz da Raça, a figura de Hitler era equiparada a de um líder forte e carismático, cujo papel seria o de recuperar uma nação destruída. Arlindo Veiga assim esclarecia:

\section{FOGO NELES}

Nações que se prezam, que tem uma doutrina nova e séria como a Itália e a Alemanha atuais, não podem permitir que uns pândegos da democracia liberal, os ladrões que até hoje vivem gritando os "imortais princípios" da Revolução Francesa, os socialistas anarquizadores e os comunista criminosos pregam libertariamento a sua estupidez...

Hitler, na Alemanha, anda fazendo uma porção de coisas profundas. Entre elas a defesa da raça alemã, defesa que chega até o exagero.

E um aspecto vivo desta atuação está no incêndio de muitos livros de escritores alemães traidores da época de fraqueza do Estado Alemão, livros que pregavam coisas inconvinientes à afirmação e renovação da Germânia. E especialmente na questão da Raça. Hitler quer a afirmação da Raça Alemã. Por isso, age logicamente. Fogo nos livros inimigos da pureza social germânica! Fogo em tudo que possa diminuir o orgulho alemão! ${ }^{367}$

O jornalista não vislumbrava a questão da superioridade de uma raça em relação a outra, mas a forma de conduzir as massas em direção a um objetivo, de maneira firme, mas

\footnotetext{
${ }^{364}$ Falaremos da polêmica entre Guaraná de Santa e Arlindo Veiga no próximo capítulo.

${ }^{365}$ A Voz da Raça, 29 abr. 1933, n.7, p.4.

${ }^{366}$ A Voz da Raça, 25 mar. 1933, n.2, p.1

${ }^{367}$ A Voz da Raça, 6 jan. 1934, n. 29, p. 1
} 
valorizando o que havia no próprio país. Porém, a última frase do artigo é um tanto contraditória, a partir do momento que coloca o negro como o integrante mais significante da sociedade brasileira :

Que nos importa que Hitler não queira, na sua terra, o sangue negro? Isso mostra unicamente que a Nova Alemanha se orgulha de sua raça. Não queremos saber de arianos. Queremos o Brasil negro e mestiço, que nunca traiu nem trairá a Nação.

Nós somos contra a importação do sangue estrangeiro que vem atrapalhar a vida do Brasil, a unidade da Nossa Pátria, da nossa Raça, da nossa língua.

Hitler afirma a raça alemã. Nós queremos a raça brasileira, sobretudo o seu elemento mais forte: o Negro Brasileiro. ${ }^{368}$ (grifo nosso)

Após a saída de Arlindo Veiga para se candidatar à Constituinte, a FNB seria dirigida por Justiniano Costa. A FNB passa então a dedicar-se mais às questões mais voltadas ao aspecto social e educativo de seu programa, enfatizando a necessidade de educação e elevação moral do negro. Em um tom moralizador mas peculiar, divulga uma cartilha de "bons modos" para o negro:

\section{CONSELHOS}

O que nós os pretos devemos saber:

- Devemos tratar todos com respeito; para sermos tambem respeitados.

- É principio de civilidade não fumar no quarto de um doente quando lhe façamos uma visita

- Precisamos tratar mais dos dentes do que dos labios.

- Quando tomar o Bonde e sentar perto de uma senhora, não devemos fumar; é falta de cortesia.

- Pessoa que está em estado interessante deve estar sempre coberta com seu casaco, quando sair para passear.

- Não devemos despresar os que não tem roupa cortada pelo ultimo figurino; porque a fartura não dura sempre.

- Necessitamos mais de ação e menos discursos.

- Não devemos fazer apresentação de uma pessoa para outro; porque aqui na capital nós somos todos conhecidos de vista.

- Quando uma pessoa estiver conversando na rua ou em qualquer lugar devemos esperal-o tres metros mais adiante para não observar assuntos que não é do nosso interesse.

- Não devemos fazer visita para ninguem na hora do almoço ou do jantar, para não ser chamado de 'Fila Boia',369

Em 1937, o combate aos maus costumes parece ser a mais importante cruzada:

Urge, por isso, que os negros se imcompatibilizem com as "paradas forçadas" que degladiam a sua sublevação, fazendo guerra persistente aos seus patricios infractores. Para apreciar um "aperitivo", não é mistér morar em "botequins".

Isso porque, se toda essa gente negra que vegeta pelas "esquinas e botequins", se regenerar e apoiar pelo menos, a campanha pró-restauração da Raça, o Brasil terá, nesta fase de controvérsias, o ponto culminante de sua Salvação. ${ }^{370}$

\footnotetext{
${ }^{368}$ Idem, ibidem.

369 A Voz da Raça, 10 junho 1933, ano I, n. 12 Apud FERRARA, Miriam Nicolau. A imprensa negra paulista...op.cit., pp. 123-124.

${ }^{370}$ A Voz da Raça, fevereiro de 1937, ano III, n. 62 Apud FERRARA, Miriam Nicolau. A imprensa negra paulista...op.cit., p. 128.
} 
No entanto, naquele mesmo ano, A Voz da Raça confirmava o caráter político da entidade por ela defendida, com o artigo "O que pretendem os negros frentenegrinos com o nome de Frente Negra Brasileira":

Ela já conseguiu, entre outras cousas que o Supremo Tribunal de Justiça Eleitoral achasse por bem reconhece-la como PARTIDO POLÍTICO em todo o territorio nacional e isto, significa um passo bem agigantado de uma nação, cujo capital de combate tem sido a capacidade e a boa vontade dos seus componentes.

(...)

Trabalham os legisladores da raça, especialmente no campo Politico, dando provas de que são capazes de competir em todo terreno das atividades humanas. ${ }^{371}$

Se a FNB pode ser considerada a mais significativa entidade organizada para defender os direitos dos negros no Brasil, A Voz da Raça foi seu mais eficiente instrumento. Isto devido ao esforço feito no sentido de arregimentar a coletividade afro descendente. Para quê? A fim de promover sua inclusão na sociedade de brancos, muito além da questão étnica, mas sob um nacionalismo baseado na valorização da memória histórica dos antepassados, à semelhança de Zumbi e Henrique Dias e colocando seus protagonistas como reais sujeitos da História.

${ }^{371}$ Idem, ibidem. 


\section{Capítulo 5 - As disputas entre as lideranças da Imprensa Negra e suas consequências.}

\subsection{Cenário político, embates ideológicos e a luta por poder.}

Muitos estudiosos da imprensa negra parecem não ter dúvidas de que os problemas financeiros gerados pelo elevado custo para manter um jornal, a dispersão e a falta de interesse dos negros em preocupar-se com temas que fossem mais importantes do que os bailes e acontecimentos similares como a implantação do Estado Novo, foram os motivos principais para a decadência do processo reivindicatório presente nos principais jornais negros paulistas da década de 20. Entre o aparecimento de O Menelik, em 1915, até o fechamento de A Voz da Raça e da Frente Negra Brasileira, em 1937, essas são as razões descritas, que acompanham invariavelmente a história dos jornais e de suas redações.

No entanto, além das notícias, artigos, editoriais e mensagens direcionadas ao público negro, que na grande maioria das vezes são repetitivos em relação aos temas aflitivos, como o combate ao analfabetismo, a necessidade de união, o subemprego, o preconceito e a exaltação da "raça", há um aspecto que chama bastante a atenção: a formação das lideranças e sobre como elas transitavam no universo dos jornais e da comunidade negra na Capital.

A pesquisa nas fontes permite observar ideias e atitudes de todos os grandes líderes da imprensa no período analisado. Partem sempre de uma matriz comum, que é primeiramente informar e em seguida conscientizar o negro sobre o que acontece em seu espaço, seja este a casa, o trabalho, o clube que frequenta ou os espaços de discussão.

Contudo, com o passar do tempo, os jornais ganham maior dimensão e acabam revelando abundantemente o que seus líderes, personificados na figura dos redatores, idealizam sobre a situação para o negro.

O surgimento dos jornais negros paulistas mais importantes coincide com alguns momentos político-econômicos muito significativos vivenciados no Estado e no país, como foi dito ligeiramente em capítulos anteriores: o crescimento exponencial de São Paulo como potência industrial, o final do primeiro grande conflito mundial, a gripe espanhola, as greves, o despertar do movimento operário, o evento modernista, a revolta dos tenentes, a decadência das oligarquias cafeeiras escravistas, a crise econômica de 29 e a chegada de Vargas ao poder.

Quando analisamos os conflitos entre as várias lideranças desde os primeiros jornais, muitas vezes nos deparamos com o confronto de ideias que a princípio se opunham, mas na 
verdade, se completavam, como espelhos de duas faces. As discussões intermináveis, os ataques através dos editoriais e as dissensões faziam parte de um conjunto de relações construídas ao longo de anos de lutas, de incertezas, desconfiança e busca da identidade do negro, que vivia em condições muito mais precárias do que o restante da população pobre de São Paulo.

Arriscamo-nos a supor que o primeiro impulso dessas lideranças foi a conscientização do negro no sentido de que este, através de uma valorização individual, fosse posteriormente o responsável por desencadear um desenvolvimento coletivo. Porém, à medida em que eles próprios se conscientizam de sua posição no meio, veem-no como um terreno fértil para implantação de seus conceitos, da idealização que possuem sobre si e os outros.

Esse processo acompanha as modificações ocorridas dentro do próprio contexto histórico, e através do que defendem suas lideranças talvez possamos explicar a decadência dessa Imprensa sobretudo através e por causa do comportamento de quem estava por trás de suas linhas. No caso de Arlindo Veiga e José Correia Leite, por exemplo

\subsubsection{Disputas entre lideranças: Arlindo Veiga e José Correia Leite}

Assumindo postura contrária à Primeira República, os integrantes da futura Frente Negra Brasileira, entre eles os irmãos Arlindo e Isaltino Veiga dos Santos, Gervásio de Morais e José Correia Leite apoiaram o Estado revolucionário de Getúlio Vargas.

Arlindo e José Correia Leite eram figuras cogitadas para compor o Grande Conselho da Frente Negra Brasileira, e antes da criação do jornal $A$ Voz da Raça, em 1933, já existiam planos para que $O$ Clarim da Alvorada pudesse ser o órgão oficial da entidade. Mas ao tomar conhecimento dos estatutos da Frente antes de sua fundação, Leite os considerou claramente inspirados no fascimo italiano. Passou a acusar diretamente Arlindo Veiga de usar a entidade como veículo de divulgação de suas ideias patrianovistas e declarando-se acima de tudo socialista, recusou-se a aprová-lo.

A essa altura os ânimos já estavam exaltados. Quando da aprovação do estatuto, o grupo de $O$ Clarim da Alvorada foi impedido de entrar. Logo após esse incidente, Correia Leite pediu demissão do Conselho.

As divergências entre Arlindo Veiga e Correia Leite se acirraram após um episódio ocorrido no final de 1931, envolvendo Isaltino Veiga Santos, então secretário geral da Frente Negra Brasileira, como já foi mencionado. Atendendo a um convite da cidade de São 
Sebastião do Paraíso para a abertura de uma sucursal da Frente, Isaltino namorou uma jovem, integrante de família tradicional, trocando cartas com ela. Pouco tempo depois, algumas pessoas na cidade descobriram que Isaltino era um homem comprometido.

Jornalistas locais comunicaram-se com o Clarim da Alvorada e a Frente Negra Brasileira, reclamando punição para Isaltino.

Os representantes de $O$ Clarim pediram explicações à Frente, mas o caso foi considerado apenas um deslize, uma "leviandade juvenil". Arlindo, irmão de Isaltino, decidiu que não eram necessárias quaisquer providências e como sua decisão era soberana, por ser o Chefe do Grande Conselho, o caso foi encerrado de vez.

Essa atitude foi a gota d'água nas relações já estremecidas entre O Clarim da Alvorada (na verdade, José Correia Leite) e a Frente Negra Brasileira (leia-se, irmãos Veiga Santos). Uma entidade financiada por dinheiro "da raça" servindo a interesses particulares de pessoas que pregavam o decoro, a moral e os bons costumes era algo inaceitável.

José Correia Leite preferiu não utilizar as páginas de seu jornal para atacar a Frente. Ao invés disso, criou um outro jornal, o Chibata, que mostrava, em seu cabeçalho, as inscrições "sem numero" e "sem anno". Seu editor se auto-intitulava "Homem Negro"; gerente: F. Xicocosta; subtítulo: “Nós somos Judas da raça, quem serão os Christos?”. Entre os espaços reservados para o editor e o gerente, havia a frase: "Quando este jornal circula, sente-se cheiro de difunto".

Esse pasquim fazia menção direta ao caso envolvendo Isaltino, e o criticava abertamente. Porém, o alvo principal era o irmão, que ainda o mantinha na direção e não tomava providências para resolver o problema.

O jornal teve somente duas edições. Segundo José Correia Leite em sua biografia, um grupo de desordeiros promoveu um "empastelamento" na redação do Clarim da Alvorada. Acreditava ele que o grupo responsável estava a mando de Arlindo Veiga, e por isso resolveu denunciá-lo. Intimado, Arlindo Veiga apresentou-se juntamente com Guaraná de Santana, então advogado da Frente Negra. Ao ser questionado, Arlindo revidou, acusando José Correia Leite de ser subversivo. A prova era sua carta de demissão, em poder de Arlindo, que não a mostrou previamente a seu advogado.

O delegado não aceitou a denúncia, sob o pretexto de que se alguém tivesse que ser acusado de subversivo, deveria ser Arlindo, por suas ligações com o patrianovismo. José Correia Leite se auto-declarava republicano, democrático e socialista. No entender do oficial, era mais sensato que uma proposta socialista coubesse dentro do regime republicano que uma monarquista. 
Após esse episódio, o Clarim publicou apenas mais um exemplar, encerrando as atividades em seguida. José Correia Leite temia por sua segurança e da família, após o empastelamento que seu jornal sofrera.

Mesmo após o incidente envolvendo a Frente Negra, O Clarim da Alvorada e o Chibata, continuavam a ocorrer ataques verbais no meio negro, principalmente iniciados por Isaltino, que insistia na tese de que queriam "tirar-lhe a Frente Negra".

Em meados de 1932, José de Assis Barbosa, mais conhecido como "Borba", teve a ideia de criar um clube para negros, tentando aplacar os rumores de disputas entre entidades. Ao contrário da Frente Negra, cujo Conselho era formado por pessoas idosas, nascia o Clube Negro de Cultura Social, destinado aos jovens, muitos deles filhos ou sobrinhos de membros filiados à Frente Negra.

O clube foi fundado em $1^{\circ}$ de julho do mesmo ano, e no dia 9 eclodiu a Revolução de 32. Com isso, as atividades iniciais da associação ficaram prejudicadas, pois parte dos jovens resolveu alistar-se e outra se afastou.

No entanto, ao final do conflito, as atividades foram retomadas e o Clube continuou aberto até a implantação do Estado Novo. Nesse espaço de tempo, a Frente Negra já se transformara em partido e buscava cooptar os jovens do Clube, oferecendo-lhes $\$ 150$ para catalogar informações de natureza política. Com isso, o Clube Negro de Cultura "perdeu" algumas de suas mentes mais promissoras, como Raul Joviano do Amaral, por exemplo, que viria a ser uma das mais importantes personalidades do meio negro, tendo sido também assíduo frequentador do Clarim da Alvorada. É possível que essas evasões tenham aumentado ainda mais o ressentimento entre Leite e a Frente Negra.

Durante o período de atuação da imprensa negra a que se refere este estudo, a ruptura entre José Correia Leite e Arlindo Veiga, causada especialmente por divergências ideológicas, foi talvez o acontecimento mais emblemático dentro do meio negro pela forma traumática como ocorreu e pela repercussão gerada nos círculos em que transitavam..

O embate entre Arlindo Veiga Santos e José Correia Leite foi claramente uma disputa de poder sobre a hegemonia entre as grandes lideranças negras. Ambos invocavam sua posição doutrinária para se fortalecer e assim o "autodidata" José Correia Leite e o acadêmico Arlindo Veiga travaram uma batalha ideológica em busca do controle do Conselho da Frente Negra.

Ao final da década de 1920, somente O Clarim da Alvorada apresentava uma representação consistente dentro da Imprensa Negra. O Auriverde e o Progresso, fundados em 1928, não apresentavam a mesma pujança e tampouco os mesmos objetivos e penetração do 
jornal dirigido por Correia Leite. O primeiro, dirigido por Deocleciano Nascimento, estava mais preocupado com o cotidiano social das associações e era apoiado diretamente pelo Clarim, ao passo que o Progresso estava muito envolvido com o centenário da morte de Luiz Gama e a construção da herma em sua homenagem. Portanto, a união de fato do Clarim e da Frente Negra através de seu jornal $A \operatorname{Voz}$ da Raça, e consequentemente de suas lideranças, implicaria praticamente no controle total da comunidade negra em termos associativos e ideológicos, o que não ocorreu pela dissidência de Correia Leite.

Em 1929, após a reestruturação promovida por "Mr. Gids", ambos reconheciam o abuso de poder que existia no Centro Cívico Palmares, do qual participaram ativamente desde o início, e com isso justificavam sua dissidência. Portanto, parecia inadmissível para Leite compartilhar a direção de uma nova entidade sob estigma do autoritarismo que ele tanto combatia nas páginas do Clarim:

A mocidade deve ser a sentinela avançada, atenta, alerta, ao menor movimento dos
adversários, para que não tenhamos, mais uma vez, de assistirmos ao tristíssimo
desmoronanento igual ao do CENTRO CÍVICO PALMARES - sociedade que
durante três anos mais ou menos, a custa de sacrifícios galgou uma posição invejável
no meio da raça e prestou alguns serviços à sociedade em São Paulo - que teve a
infelicidade de recolher em seu seio um indivíduo desclassificado que se tornou um
sócio ativo e batalhador que iludindo a boa fé de alguns moços inexperientes,
transformou-a num antro detestável onde reuniu e está reunindo a escória ralé da
raça para oferecer-lhe pinga e organizar uma "bagunça" (...) $)^{372}$

Nesse trecho, Leite ataca veladamente Isaltino Veiga Santos, fazia parte anteriormente da diretoria do Centro Cívico Palmares, num momento em que a relação entre os dois estava bastante estremecida em virtude do acontecimento em São Sebastião do Paraíso, a que nos referimos páginas atrás.

Com isso, não se pode dizer que a permanência de Correia Leite no Conselho da Frente implicaria mudança de posições, mas poderia também ser entendida como outra forma de autoritarismo, já que dificilmente abria mão de suas convicções. O autoritarismo de Arlindo Veiga, como Presidente Geral do Grande Conselho da Frente Negra, era a forma institucional para manter intactas as suas.

O certo no entanto é que ambos revelaram grande capacidade para convencer, arregimentar, inspirar e liderar pessoas em torno daquilo que acreditavam.

Leite manteve-se fiel ao que entendia serem ideais socialistas, porém nossas pesquisas não encontraram especificamente nenhum depoimento ou comentário que explicitasse o conceito que ele tinha sobre "ser socialista". É possível que sua percepção estivesse vinculada à situação político-partidária dos anos 20 e 30, em que existiam basicamente os

372 O Clarim da Alvorada, novembro de 1931, p. 1. 
conceitos de direita e esquerda. Seu depoimento a Márcio Barbosa sobre a proposta de criação da Frente Negra Socialista parece confirmar algumas de nossas afirmações:

\begin{abstract}
SOCIALISTAS
Muita gente pensa que foi só o Clarim que foi dissidente, mas não fomos os únicos, houve outros. Houve um grupo que saiu de lá com o nome de Frente Negra Socialista. Era um grupo de esquerda que estava lá dentro, mas viram que as ideias do Isaltino e do Arlindo estavam prevalecendo, que era um negócio de direita, então eles saíram com o nome de Frente Negra Socialista. Só que não conseguiram progredir. (...)
\end{abstract}

Arlindo continuou por muito tempo vinculado ao movimento patrianovista, sobre o qual já tecemos alguns comentários, tendo inclusive dirigido um jornal especificamente para este fim $^{373}$.

\title{
5.1.2. Outras lideranças: Lino Guedes, Gervásio de Moraes, Correia Leite e Vicente Ferreira
}

Em capítulo anterior, foi apontada a relação do jornal campineiro Getulino com outros periódicos da imprensa negra espalhados pelo Estado, bastante intensa, principalmente com $O$ Kosmos e $O$ Clarim da Alvorada. Concretizava-se em artigos compartilhados entre os três, na participação conjunta dos jornalistas em mais de um jornal e nas visitas frequentes que uns faziam aos outros ${ }^{374}$. Deocleciano do Nascimento, redator e fundador de $O$ Menelik, e Jayme de Aguiar, do Clarim da Alvorada, enviavam artigos para o Getulino.

Como também já foi dito, o poeta Lino Guedes veio para São Paulo em 1926, acompanhado de Benedito Florêncio e Gervásio de Moraes. Mas bem logo, o que parecia uma relação de harmonia tornou-se desavença pessoal entre Lino Guedes e o Clarim, mais especificamente com José Correia Leite, que, segundo Luis Silva, não demonstrava simpatia alguma pelo jovem versejador:.

(...) O Benedito Florêncio era um grande orador. O Gervásio de Moraes também tinha esse pendor, essa vocação de oratória. O Lino Guedes nem tanto. Era um negro isolado. Foi na época o único negro a editar livros de poemas. Do meu modo de ver, ele procurava fazer um tipo de poesia imitando as Trovas Burlescas, do Luiz Gama. O Lino Guedes nem sempre agradava o meio negro com o trabalho literário dele. ${ }^{375}$

\footnotetext{
${ }^{373}$ Encontramos um exemplar do jornal Monarquia - Órgão da Chefia Geral Patrianovista, datado de janeirofevereiro de 1961, ano VI, n. 35, em que Arlindo Veiga aparece como seu diretor e Chefe Geral Patrianovista. ${ }^{374}$ Consta a visita do Getulino à diretoria do Kosmos em São Paulo, registrada na edição no. 57 (12 de outubro de 1924) do primeiro e a homenagem prestada pelo Clarim da Alvorada aos editores do Getulino, presente na edição n. 12 de 25 de janeiro de 1925 do jornal paulistano.

375 SILVA, Luis. Op. Cit., p. 38.
} 
Correia Leite cita esse e outros comentários em sua biografia. O poeta de Black seria um negro isolado porque era "desses que queria fazer as coisas sozinho". Em São Paulo, fundara em 1928 o jornal Progresso, onde era o editor, junto com Argentino Celso Wanderley. O periódico dava, assim, continuidade ao projeto do Getulino na capital paulista, pretendendo "promover a elevação dos negros, conduzindo-os ao caminho do progresso".

Como já foi relatado, às vesperas do centenário do nascimento de Luiz Gama, Argentino Celso Wanderley pretendeu construir uma herma em praça pública homenageando o abolicionista. Convidou várias pessoas para a empreitada, entre elas os redatores do Clarim da Alvorada e Correia Leite, que declinou por estar envolvido diretamente com a preparação do Congresso da Mocidade Negra. Lino Guedes, por sua vez, aceitava fazer parte da comissão para construção do monumento, desde que fosse o orientador e não houvesse a participação do Clarim.

Dias antes, o editor do Progresso propôs ao Clarim que continuassem com o Congresso, mas exigia exclusividade na matéria sobre Luiz Gama, que lhe foi negada imediatamente. Segundo Leite, ninguém podia se arvorar em “dono de Luiz Gama”, e o jornal se reservava o direito de publicar o que quisesse a respeito ${ }^{376}$.

O redator do Clarim referia-se ao Progresso como "órgão noticioso da comissão da herma do Luiz Gama" e atribuía a autoria do projeto a Wanderley, ao invés de Guedes. A despeito de tudo, a herma foi finalmente inaugurada em 21 de junho de 1930, no Largo do Arouche tornou-se um grande acontecimento para a comunidade negra, a julgar pela quantidade de pessoas que conseguiu reunir. Todo o projeto custou em torno de 11 contos, e ao final, o Clarim circulou em edição especial, aderindo à campanha. ${ }^{377}$

O que aparentemente incomodava Leite em relação ao ex-redator do Getulino era a trajetória literária dele, em oposição à sua própria. Lino Guedes, desde muito jovem, percebeu a importância dos estudos como mola propulsora para seu sucesso e pregou essa importância praticamente durante toda a carreira nos jornais. Sua história de vida se assemelharia à de Gama (pelo menos esse seria seu ideal de vida), portanto, estar entre negros incultos, que não partilhassem de seu perfil idealizado, o incomodaria.

Alguns anos mais tarde, um artigo escrito pelo reconhecido escritor Afonso Schmidt reproduzia um diálogo que teve com o editor do Progresso:

\footnotetext{
${ }^{376}$ SILVA, Luis. op.cit., pp.85-87

${ }^{377}$ Idem, ibidem, p. 88
} 
Lino Guedes, poeta negro nascido em Socorro, distinguiu-me com sua amizade. Sempre que nos encontrávamos na rua, tínhamos uma conversinha:

- Você tem lido meus poemas? - perguntava-me ele.

- Tenho, mas estou triste...Você escreve não como um poeta de sua raça, mas como um branco que se interessa pelos negros. Ora, você, neto ou bisneto de africanos, vivendo no meio de sua gente sentindo no próprio coração o sofrimento dos seus irmãos de cor, deveria arvorar a bandeira das suas reivindicações...

Seu rosto doente se assombrava:

- Não posso, meu caro. Sou muito mal compreendido. Muitos de meus parceiros não gostam de mim...

E numa voz sumida, cheia de ressentimentos, concluía a frase:

- Esses, mal orientados, chegam a dizer que eu conto histórias de pretos para divertir os brancos. ${ }^{378}$

Guedes tinha plena convicção de que não era unanimidade no meio negro.

O líder do Clarim, por sua vez, julgava-se um sobrevivente, na medida que, sem o apoio dos pais ou a proteção de famílias de senhores de escravos, semi-analfabeto e com pouca cultura, conseguira conquistar uma respeitável posição como uma das mais influentes personalidades dentro da comunidade negra.

Da mesma forma, e seguindo critérios pessoais, possuíam sentimentos opostos em relação a Vicente Ferreira. Este, um excelente orador, era na verdade semi-analfabeto, "mal sabia assinar o próprio nome", andava sempre mal vestido e vivia de favores. Apesar da reconhecida fama como militante do movimento negro no Rio de Janeiro, era muitas vezes visto como "um sujeito perigoso", na opinião de Correia Leite. Lino Guedes chegou a procurá-lo pouco depois de sua chegada a São Paulo, em 1926, para que prefaciasse um de seus livros de poesia, mas ante a descoberta de que isso não seria possível pelas limitações de escrita daquele, ressentiu-se, considerando-se vítima de um engodo. O "professor" Ferreira, na verdade, representava tudo aquilo que ele rejeitava através de suas notas e editoriais no Getulino: o negro sem modos, rude, sem cultura.

Por sua vez, José Correia Leite respeitava demais a capacidade de superação de Vicente Ferreira, chegando a equipará-lo ao poeta Gervásio de Morais na qualidade da oratória. Detentor de uma memória fabulosa nas palavras de Raul Joviano do Amaral, Ferreira não conseguia escrever, mas era assíduo leitor de bibliotecas e assimilava os temas relacionados ao negro e às questões políticas com grande propriedade. Promoveu diversos debates junto a outros jornais da grande imprensa de São Paulo, e quando queria ser ouvido, ia diretamente às suas redações, exigindo providências. Foi colaborador frequente do Clarim, entre 1926 e 1932, quando passou a frequentar a Frente Negra. Apesar das divergências de

\footnotetext{
${ }^{378}$ Diário do Povo, 10 out. 1953 APUD MIRANDA, Rodrigo. Um caminho de suor e letras... p. 247.
} 
Correia Leite com essa entidade, ele também reconhecia que a redação do Clarim "não era um bom lugar para discursos",379.

Provavelmente o jornalista do Clarim via a si mesmo em Vicente Ferreira, ou seja, o negro discriminado, com pouco conhecimento técnico, mas igualmente grande, capaz de superar todas as adversidades, aquele que alia o discurso à ação. Alguns dos artigos mais bem elaborados pelo Clarim foram de autoria de Vicente Ferreira, "todos ditados", escreveu Leite em suas memórias. Mas isso parecia não o incomodar.

$\mathrm{Na}$ verdade, tanto Guedes quanto Leite valorizavam nos seus patrícios o modelo de negro que idealizavam a respeito de si mesmos. O primeiro, tendo vivido em meio a intelectuais, valorizava-se também como exemplo de superação; era o filho de ex-escravos que conseguiu "vencer na vida" dentro da sociedade dos brancos, e qualquer crítica a seu trabalho seria fruto de uma "falta de compreensão". Leite, guardadas as devidas proporções, julgava-se a imagem do self made man dentro da comunidade negra, pelo seu histórico de convivência pacífica com os italianos, a infância difícil sem o acesso sonhado à escola, a morte da mãe por problemas relacionados à saúde mental, a criação e a condução do Clarim, a falta de recursos financeiros, para si e para o jornal. Tendia a supervalorizar o esforço individual e a ação efetiva, a atitude, em detrimento das questões intelectuais. Não escondia das pessoas mais próximas sua aversão ao excesso de poemas nos jornais, nem mesmo de seu parceiro Jayme de Aguiar, que "insistia em recitar sempre algum verso quando podia". Também criticava as edições recheadas de homenagens, referindo-se a elas como jornais "xarope".

Vicente Ferreira nos parece ser a antítese do que Florestan Fernandes, Roger Bastide e Clóvis Moura colocaram a respeito das pessoas que fazem os jornais dessa imprensa negra.

Os negros intelectualizados participaram ativamente da criação dos mesmos e de sua idealização, mas nem sempre se tornaram seus protagonistas. Vicente Ferreira destacava-se pela emoção e capacidade de reunir seus irmãos de cor, mesmo que em torno apenas de seus discursos e para participar de algumas manifestações em prol da raça negra, tarefa considerada de difícil execução pela maioria dos jornais e militantes da época. Não satisfazia o perfil daquele pertencente à "classe média negra", para utilizarmo-nos de um termo de Bastide, e tampouco era um negro "letrado" na acepção da palavra. Mas destacava-se em meio à multidão, o que, dentro daquele contexto, já significava muito.

${ }^{379}$ SILVA, Luiz. op. cit., p. 69 
O mesmo conceito se poderia dizer do Tio Urutu, a que nos referimos no terceiro capítulo: um funcionário subalterno do Instituto Disciplinar, que tirava de seus parcos vencimentos (fato comum entre os negros mantenedores dos jornais) o sustento de uma pequena Folha, o Princesa do Oeste.

Jayme de Aguiar e Raul Joviano nutriam simpatia e até admiração pelo "preto gordo, de cabelos grandes" em relação a esse esforço. Para Leite, no entanto, Tio Urutu não passaria de um negro que gostava de fazer pesquisas sobre os "podres" das pessoas para poder divulgá-los em seguida em seu jornal de "cavação" ou nas associações. Não seria mais que um "criador de casos".

O jornal A Liberdade menciona-o em uma de suas edições, na seção "Críticas":

[crítica] com o Antonio Urutú ter deixado de pagar os tres mil réis da A Liberdade, para inteirar para publicar o seu jornal Estrella do Norte. Pague os seus cadaveres que são muitos que nós sabemos. ${ }^{380}$

Para repetir ainda uma vez, a questão de inadimplência e da gestão dos recursos financeiros eram fatores críticos para a sobrevivência dos jornais, por isso a veemência na cobrança de mensalidades atrasados e de valores prometidos e não entregues aos redatores ou responsáveis pela publicação e distribuição.

Correia Leite, Lino Guedes e Vicente Ferreira, cada um a seu modo, foram lideranças significantes, que ao mesmo tempo se opuseram e se completaram.

\subsubsection{Lealdade, dissensão e luta armada}

Guaraná de Santana foi, algum tempo, advogado da Frente Negra Brasileira e colaborador de Arlindo Veiga Santos. Como assessor jurídico da FNB, entendia fazer parte de uma organização complexa, assumindo então uma postura de certa forma independente no sentido de ter suas próprias opiniões, até mesmo por conhecer bem o aparato legal que poderia manter a Frente em funcionamento regular.

Ao mesmo tempo, participava ativamente de questões pessoais ligadas aos membros do Conselho e dos afiliados, em especial, de Arlindo Veiga, como no episódio envolvendo o empastelamento da sede do Clarim. E é de se supor também que assessorasse o "Chefe" em suas comunicações frequentes ao DEOPS para informar a respeito de pessoas suspeitas dentro do meio negro.

\footnotetext{
${ }^{380}$ A Liberdade, anno I, n. 15, 9 maio 1920, p.4
} 
Ao que nos parece, o advogado foi vítima das próprias ideias, quando de sua expulsão da Frente Negra em 1932, exatamente por não falar como "pessoa autorizada" por ela (entenda-se Arlindo Veiga). Um documento elucidativo sobre a questão nos parece ser este ofício $^{381}$ enviado ao delegado de Ordem Política e Social:

\author{
Ofício n. 509 \\ Da Secretaria Geral \\ S. Paulo 11 de junho de 1933. \\ Exmo. Sr. Dr. Armando Soares Caubi \\ D.D. Delegado de Ordem Política Social \\ NESTA. \\ Illustre Patrício. \\ - Por intermédio da presente, em nome da Frente Negra Brasileira tomamos a \\ liberdade de levar ao conhecimento de V. Excia. o seguinte:- Ultimamente, com o \\ fito de um saneamento moral, no seio da Gente Negra desta cidade, os dirigentes da \\ F.N.B., viram-se forçados a expulsar do seio frentenegrino, diversos elementos que \\ de a muito vinham embaraçando a nossa marcha social, inclusive o Dr. J. Guaraná \\ de Sant'Anna, isto porque não nos interessa de maneira alguma envolvermos em \\ política, mesmo porque temos coisa de imediato interesse a tratar, como por \\ exemplo, alfabetisação geral da nossa gente, caixa beneficente, compriendendo-se \\ assistencia juridica, instrucção militar, etc., pois é dessa maneira que nós os \\ frentenegrinos queremos contribuir ajudando a V. Excia. (...) \\ Com a expulsão dos negros acima citados, formaram eles clandestinamente, \\ ajudados por politicos interesseiros, a tal Frente Negra Brasileira Socialista; esse \\ caso porém já havia sido enviado ao ilustre chefe de policia demissionado, que \\ tomou as devidas providencias (...) \\ Sem outro assunto gratos pela atenção que nos tem sido dispensada em nome da \\ F.N.B, subscrevemo-nos de V. Excia (DEOPS, promptuario 1538, grifos nosso)
}

Guaraná de Santana foi afastado da Frente Negra supostamente por não concordar com a forma de gestão que estava ocorrendo na entidade e tentou levar adiante a ideia da Frente Negra Brasileira Socialista, em oposição clara à postura nacionalista da FNB. No entanto, não tivemos acesso a documentação suficiente para atestar o funcionamento dessa nova entidade.

$\mathrm{Na}$ verdade, o advogado ficou mais conhecido por sua atuação à frente da Legião Negra, situada na Chácara do Carvalho (Alameda Eduardo Prado, 69), que arregimentou negros para lutar durante a Revolução de 1932. Os negros eram alistados em todas as partes do Estado, e "não levavam mais do que dois ou três dias para aprender a lidar com o fuzil e essas coisas, e já estavam aptos para ir para a guerra"382. Em 20 de julho de 1932, a equipe de reportagem do Correio de São Paulo informava que, em apenas quatro dias, o alistamento alcançara mais de 500 negros $^{383}$.

Mas a euforia inicial passou à frustração quando São Paulo foi derrotado no conflito. Percebeu-se que os desfiles em carros pelas cidade, os aplausos e o apoio do governo não íam

\footnotetext{
${ }^{381}$ APUD SANTOS, Pedro de Souza. op. cit., pp. 54-55.

382 José Correia Leite IN: SILVA, Luis, op. cit., p. 104

${ }^{383}$ Apud GOMES, Flávio. Negros e Política (1888-1937). Jorge Zahar, 2005, p.67.
} 
muito além da retórica. Após os combates, os negros "ficaram espalhados pela cidade feito lixo humano", o que fez Guaraná de Santana dizer algum tempo depois, que aquela fora "a última grande lição aprendida pela raça negra". 384

Ele ainda ajudou a fundar a Tribuna Negra, em 1935, que se dizia porta-voz dos negros combatentes da Legião Negra, e antes disso, em 1933, fundou o jornal Brasil Novo, com uma postura socialista, e transformou a Legião em entidade civil. Segundo Correia Leite, essa entidade voltaria em 1945, mas sem a mesma postura de antes.

Quanto ao episódio entre Guaraná de Santana e Arlindo Veiga, repetimos que um dos aspectos da liderança no meio negro talvez decorresse do posicionamento pessoal frente aos acontecimentos relevantes do cotidiano, tanto sociais quanto econômicos ou políticos.

Os dois acreditavam, cada um a seu modo, que a ação militarizada e disciplinada era justificada. Sem se tornar uma ameaça à paz, seria uma defesa contra aqueles que queriam promover desequilíbrios.

Para a FNB a preparação militar do negro o auxiliaria na busca do progresso de sua raça, do país e na construção de uma "Pátria Nova" extirpada da "Bastilha feroz".

Ela não apoiou o movimento de 1932 ao contrário da Legião Negra, pois segundo pensava, a preparação militar de seus quadros era o mais sensato a fazer naquele momento. Conforme Francisco Lucrécio em depoimento pessoal, o negro recebia treinamento apropriado e estaria pronto para agir, em caso de invasão, por exemplo. ${ }^{385}$

Mesmo em lados ideologicamente opostos, Santana e Veiga Santos acreditavam liderar e conduzir pessoas em torno de suas convicções para solucionar o "problema do negro" no Brasil, lançando mão, se preciso, da violência como forma disciplinadora e instrumento de conquistas.

Todas as discussões apresentadas ocorreram em um período de profundas transformações políticas: a Revolução de 1930, as mudanças nas leis trabalhistas, a Revolução de 1932, a preparação para a Constituinte e a possibilidade de participação política, até a chegada do Estado Novo. O negro não esteve, portanto, alheio a esse processo, e sua atuação teve respaldo nas lideranças, naqueles, entre outros, que surgem em momentos nos quais a ação é necessária, que têm carisma e capacidade de convencimento, mesmo que frequentemente, variem tanto a forma quanto o conteúdo de suas propostas.

\footnotetext{
${ }^{384}$ Ver GOMES, Flávio. Negros e Política...pp.67-77

${ }^{385}$ IN: BARBOSA, Márcio. op.cit., pp.35-64
} 


\title{
5. 2 - Permanências e mudanças. O declínio do caráter reivindicatório nos jornais negros
}

Em um depoimento tomado por Clóvis Moura, o depoente diz que pelo menos até 1936 o preconceito era visível nos anúncios de aluguel dos porões do Bexiga. Dizia-se:

\begin{abstract}
Aluga-se quarto, não se aceita pessoas de cor, e nos jornais saíam anúncios pedindo empregadas brancas, foi se acalmando. Com isso, o negro pensou que o motivo da luta também se acalmou. As contradições raciais ficaram diluídas nas contradições sociais e econômicas. Desta forma o negro pensa que não há mais necessidade de uma imprensa negra de protesto. ${ }^{386}$
\end{abstract}

A declaração de Aristides Barbosa, ex-integrante da Frente Negra Brasileira, é bastante emblemática e mereceria uma análise mais detalhada. De forma comum, todos os periódicos buscaram um objetivo, desde o começo: a integração do negro na sociedade brasileira. O negro não quis disputar lugar com o branco, não queria afrontá-lo, somente queria ter as mesmas condições de viver como parte importante da história do país. Mas a realidade era outra: o negro continuava excluído e tinha sérios problemas para resolver, sobretudo em São Paulo.

Acompanhando o contexto político, visualiza mais uma vez a possibilidade de engajarse através do voto, uma vez que as tentativas anteriores foram desgastantes, seja pela falta de dinheiro para manter a reivindicação aberta, seja pelo momento conturbado pelo qual passou o país com suas revoluções e crises econômicas.

Nos anos 1930, ainda havia reivindicações e denúncias contra o racismo, o preconceito e a discriminação, mas concentradas em poucos periódicos: enquanto na primeira fase havia um número elevado de pequenos jornais que se dedicavam praticamente às mesmas questões, na segunda fase apenas quatro são dignos de destaque: Getulino, Clarim da Alvorada, Progresso e A Voz da Raça, com posturas ideológicas razoavelmente definidas.

Nos chamou a atenção uma nota publicada na edição de 28 de setembro de 1930 do Clarim da Alvorada, portanto, a menos de uma semana do golpe de 3 de outubro que deu início à era Getúlio Vargas. A nota fala da expectativa em torno da posse do novo governador do Estado, um acontecimento pouco comum nas páginas da Imprensa Negra, principalmente por fazer comentários sobre um partido político:

O Partido Republicano Paulista, atravessa nesse instante, uma dessas fases que costumamos chamar - agudas. O momento é de grande responsabilidade, para a vida do Estado e para a tradição desse gremio político. É uma hora de ansiedade popular

\footnotetext{
${ }^{386}$ Depoimento tomado por Clóvis Moura em 15 de junho de 1975 IN: MOURA, Clóvis. Sociologia do Negro Brasileiro...op. cit., p. 216
} 
pelas "demarches" que deverão ser feitas, em torno da escolha do futuro presidente do Estado.

(...)

Um nome integro e que merece a confiança dos paulistas, é que os proceres do P.R.P. devem indicar. Nós que somos um fragmento desse povo, que estamos incorporados às suas aspirações, fazemos aqui a nossa fé pública, confiando unicamente no patriotico momento em que o P.R.P. fallará qual será o substituto do governo cadente... ${ }^{387}$

Mais do que a análise do teor da nota, observamos que mesmo sendo uma edição comemorativa, dedicada substancialmente à Mãe Preta, não há praticamente nenhum artigo, editorial ou carta de colaboradores falando em reivindicações ou comentando problemas relacionados à população negra de São Paulo, algo comum em outras épocas, pois os momentos de celebração eram oportunos para a conclamação aos negros pela mobilização.

Como foi visto no capítulo anterior, as reivindicações da população negra aparecem em grande número nas páginas de $A \operatorname{Voz} d a \operatorname{Raça}$, as quais não refletiriam necessariamente os anseios da comunidade, mas sim os dos responsáveis pela Frente Negra Brasileira, que tinham postura abertamente favorável ao nacionalismo, simpatia em relação ao Integralismo, a valorização do mestiço brasileiro e contra os costumes africanos, além claro de sua evidente inclinação político-partidária. Com isso, o tom mais incisivo das manifestações da imprensa negra ficaram restritos ao que era veiculado nas páginas desse jornal.

Comparando a duração dos principais periódicos da segunda fase da Imprensa Negra (1923-1937), notamos que as últimas edições coincidem com os acontecimentos mais importantes da década no Brasil e em São Paulo.

\begin{tabular}{|c|c|}
\hline Jornal & Período \\
\hline Getulino $^{388}$ & $1923-1924$ \\
\hline O Clarim da Alvorada & 1924-1932 \\
\hline Progresso & $1928-1930$ \\
\hline A Voz da Raça & $1933-1937$ \\
\hline
\end{tabular}

Pode-se notar que o período regular de publicações desses quatro jornais termina sempre com um conflito armado ou uma revolução, sem falar da proximidade a duas guerras mundiais. Significa também quatro ciclos em treze anos, às vésperas do cinquentenário da abolição.

\footnotetext{
387 O Clarim da Alvorada, 28 set. 1930, ano VII, n. 30, p.3

${ }^{388}$ O Getulino teve 64 edições publicadas entre julho de 1923 e dezembro de 1924, com edições comemorativas em 13 de maio dos anos de 1925 e 1926. Para efeitos de comparação, será considerado último ano de publicação regular.
} 
Cada ciclo estampa toda a trajetória do negro na cidade de São Paulo, os anseios, as histórias de luta, mas também as frustrações e o cansaço. A cada três ou quatro anos as reinvidicações se intensificam, e sinas de mudanças para a comunidade não são vistas.

Todos os autores que estudaram esses jornais são unânimes em afirmar que o golpe fatal contra as pretensões de união e solidariedade para a integração do negro em São Paulo foi a implantação do Estado Novo, porém a frustração com a Revolução de 1930 e o Movimento de 1932 já vinham minando o terreno das reivindicações.

Visto pela ótica dos periódicos negros, o movimento negro pode ser considerado o produto da conjuntura política e econômica vigente na cidade, gerando reações diversas de cada liderança e associação, que agiam de acordo com suas convicções. Estas eram reflexo das ideologias vigentes à época e visavam articular o negro contra sua cadente exclusão, agravada pelos privilégios estendidos pela República aos imigrantes, processo do qual o trabalhador nacional também era vítima. Como opina Regina Pahim Pinto, seria também resultado da "inexperiência política dos negros e de sua tendência a imitar movimentos de sucesso". 389

Pensamos que foi um erro tático das lideranças, a concentração do movimento reivindicatório (nem sempre visível e identificável) em poucas mãos. Ao eleger a Frente Negra Brasileira como porta-voz dos negros e a entidade mais representativa da comunidade, Arlindo Veiga dos Santos passou a deter poder excessivo, tanto através daquela entidade como na difusão de suas ideias patrianovistas. Essa postura afastou a possiblidade de implementação de programas mais abrangentes, pois as propostas resumiam-se a expressar a vontade e as convicções de uma minoria elitizada.

As mudanças a que nos referimos no título deste capítulo se explicam no teor e no alcance das reivindicações, que passam do cunho social ao político. As da FNB não visam mais o acesso à educação de qualidade, o trabalho em ocupações adequadas à formação do negro ou a compra da casa própria. O negro necessitava conscientizar-se que não deveria mais sujeitar-se a "capachos de ambiciosos, capangas braçais ou intelectuais" ou sofrer com as "explorações partidárias", 390

O historiador Flávio Gomes resumiu assim o clima política da época, representado principalmente pela FNB:

O que importa destacar é que efetivamente os temas da raça e da revolução, mesmo que sob diversas roupagens, constituem os debates políticos do período, seja no discurso que enfatiza a Nação através de inúmeros símbolos patrióticos, seja nos

\footnotetext{
${ }^{389}$ PINTO, Regina Pahim. O movimento negro...apud OLIVEIRA, André Côrtes. Quem é a Gente Negra...p.102

${ }^{390}$ A Voz da Raça, 15 abr. 1933, n.5, p.1
} 
projetos que investem numa revolução resultante dos embates entre classes sociais antagônicas. ${ }^{391}$

Outro exemplo de mudança estratégica nos rumos das reivindicações, atrelada às convicções de suas lideranças, é o programa de Arlindo Veiga Santos para a sua candidatura à Constituinte Nacional de 1933. O mote "Deus, Pátria, Raça e Família” era a base a ser seguida para garantir aos frentenegrinos um futuro livre das ameaças externas, num contexto de religião, unidade familiar e valorização da "raça":

\footnotetext{
Neste gravíssimo momento da NACIONALIDADE BRASILEIRA, dois grandes deveres incubem os negros briosos e esforçados, unidos num só bloco na FRENTE NEGRA BRASILEIRA: a defesa da Gente Negra e a defesa da Pátria, porque uma e outra coisa andam juntas, para todos aquelles que não querem trair a Pátria por alguma forma de internacionalismo. ${ }^{392}$
}

Em seu programa, defendia a criação de um Estado Orgânico-Sindicalista que lutaria para valorizar quatro pilares: a Terra, o Sangue, o Trabalho e o Espírito. Para ele, essa foi a base sobre a qual se construiu a pátria brasileira, e somente uma doutrina forte seria capaz de garantir a sua soberania e continuidade:
"Criou-se a FNB para unir, educar e defender os negros; para cooperar na renovação político-social da Nação, integrando nela completamente os netos de Zumbi. Já se viu movimento algum sem doutrina? Já se viu navegação sem bússola? Já se viu andar sem saber o caminho? Já se viu obra sem instrumento?
Dessas considerações nasceu o ORGANICO-SINDICALISMO, único regime que poderá considerar a Gente Negra patrícia como uma realidade nacional que, portanto, terá de ser atendida. Qualquer forma de democracia, de igualitarismo, não nos serve. ${ }^{393}$

O rompimento entre José Correia Leite e Arlindo Veiga Santos (ou como querem alguns, entre Clarim da Alvorada e Frente Negra Brasileira) talvez tenha sido o último trecho de uma caminhada rumo ao movimento reivindicatório mais abrangente no período analisado, pois impossibilitou o diálogo com as diferenças políticas entre os remanescentes das duas organizações mais representativas do movimento negro na década de 1930. Não cabe, porém, tecer comentários ou especular sobre como seria o futuro da comunidade afrodescendente se não houvesse tal ruptura.

Tem razão Florestan Fernandes quando diz que "à inexperiência política se somou uma condição fortuita mas crucial: pela primeira vez se concretizava, no "meio negro", a possibilidade de competir por prestígio e poder na arena política" ${ }^{, 394}$. E essa inexperiência,

\footnotetext{
${ }^{391}$ GOMES, Flávio dos Santos. Negro e Política...p.62

${ }^{392}$ A Voz da Raça, 18 mar. 1933, n. 1, p. 1.

${ }^{393}$ A Voz da Raça, 3 jun. 1933, n.11, p.1

${ }^{394}$ FERNANDES, Florestan. A Integração do negro...vol. 2, p. 62
} 
somada aos efeitos das turbulências do período, às diversas disputas ideológicas dentro da imprensa e do próprio movimento negros fizeram acelerar um processo de decadência que se estenderia até 1945, quando as formas de resistências assumiram caráter essencialmente cultural, como a criação da Associação do Negro Brasileiro, por José Correia Leite e, um ano antes, do Teatro Experimental do Negro (TEN), de Abdias Nascimento, ao mesmo tempo em que se vivenciava a volta da democratização do país. ${ }^{395}$

${ }^{395}$ Sobre Associação dos Negros Brasileiros, ver FERNANDES, Florestan. A integração do negro...vol. 2, p. 106. Sobre Abdias Nascimento e o Teatro Experimental do Negro, ver <www.abdias.com.br> e LOPES, Nei. Enciclopédia Brasileira da Diáspora Africana...p. 643. 


\section{Conclusões}

No decorrer desta modesta pesquisa, tentamos mostrar na trajetória da Imprensa Negra Paulista alguns aspectos diferentes daqueles contados nos estudos até hoje realizados.

Para tanto, estudamos a situação dos negros em São Paulo através das páginas de jornais escritos por eles mesmos, com todas as particularidades que um empreendimento desse tipo poderia apresentar. A exemplo de outros autores que também abordaram o tema da Imprensa Negra, procuramos descrever o surgimento, a organização, a dinâmica de funcionamento e a forma como esses periódicos eram vistos pela comunidade negra.

Nesse trajeto, achamos que seria interessante e ilustrativo, oferecer comentários não limitados aos jornais surgidos dentro do recorte espacial escolhido. Além disso, procuramos vincular as temáticas da educação, do trabalho, da saúde e da habitação, sempre recorrentes em todos eles, à história e às origens da exclusão do negro em São Paulo. Esta seria também uma das razões que explicam o aparecimento da Imprensa analisada.

Por isso remontamos à época do seu surgimento em São Paulo ainda no período escravista. Mesmo então já havia periódicos que tratavam a questão do escravo e do liberto como assunto de considerável importância, reivindicando atenção especial aos seus direitos.

Como se viu, no período pós-abolição o negro liberto continuou excluído, apesar do processo acelerado de urbanização e dos anseios de modernidade que transformaram profundamente a Capital paulista. Já que na historiografia compulsada não vimos dados estatísticos ou tabelas que confirmassem quanto a exclusão do afrodescendente ainda continua nos dias atuais, achamos importante introduzi-los no primeiro capítulo.

Em nosso entender, a atuação das Irmandades e Associações foram os verdadeiros embriões dos jornais negros e de seus aspectos reivindicatórios. Daí a inclusão de comentários sobre elas no capítulo 2.

Nossa proposta de periodização para as fases da Imprensa Negra em São Paulo não coincide com as dos historiadores que pesquisaram o tema. Baseamo-nos não somente na revisão de todos os estudos realizados, mas também no teor dos editoriais dos jornais e suas características. Nossa escolha pelo Getulino para abrir a segunda fase dessa imprensa, em 1923, confirma a tese de que o amadurecimento e a evolução dos periódicos negros se dá a partir do conteúdo das matérias e do caráter incisivo das reivindicações do jornal campineiro, além da organização e da capacidade de seus editores. 
A par dos temas restritos ao universo da população negra em São Paulo, como o racismo, o branqueamento, a anomia ou o detalhamento das características de determinado jornal, achamos importante valorizar detalhes às vezes ignorados pela historiografia, como a frequência dos anúncios publicitários, a localização dos anunciantes, cartas de leitores e notícias sociais. Entendemos que mesmo nas notas de diversão existe o espírito crítico dos jornais, principalmente dos negros, que buscavam ser ouvidos e atendidos em suas reivindicações.

A imprensa negra conseguiu reunir um grupo representativo de pessoas para empreender a batalha contra o "preconceito" racial, como se dizia na época. Essas lideranças eram extremamente respeitadas dentro da comunidade negra, não só pela atuação jornalística, mas pelo histórico associativo. Possuíam capacidade de agregar e convencer a população no caminho da mobilização e conscientização, fazendo parte do que consideramos a base do movimento negro na primeira metade do século $\mathrm{XX}$.

Da mesma forma, os conflitos e as divergências sobre como alcançar a tão almejada integração e cidadania estavam sempre presentes, como em todos os grupos sociais que se propõem a buscar objetivos desafiadores ou grandiosos.

Muitos desses conflitos eram de natureza ideológica, como acreditamos ter mostrado ao longo do trabalho.

Após anos de militância nos periódicos, de todas as dificuldades e (poucas) conquistas, o negro visualizou na política o meio definitivo para se fazer ouvir e representar, o que, no entanto, não aconteceu.

O enfraquecimento do caráter reivindicatório se consolidou na implantação do Estado Novo, afirmação que consideramos inexistente na historiografia, mas já se anunciava muito antes disso, ou seja, alguns desses sinais já apareciam na permanência de poucos jornais da segunda fase, entre 1923 e 1937.

As revoluções, os conflitos armados e a perseguição política na cidade a partir de 1924 foram minando a resistência de um grupo de intelectuais negros, tais como os muitas vezes citados Deocleciano do Nascimento, Frederico Baptista, Jayme de Aguiar, Arlindo e Isaltino Veiga dos Santos, Correia Leite, Lino Guedes, Gervásio de Moraes e tantos outros, que se dispersaram por ocasião do Estado Novo.

Mas algumas dessas lideranças se projetaram no cenário político. Arlindo Veiga dos Santos, por exemplo, grande líder da Frente Negra Brasileira, deixou a entidade em 1934 para candidatar-se à Constituinte. Pouco antes, a FNB e seu principal artífice haviam assumido definitivamente uma postura política em relação às questões do negro. Sua saída faz com que 
a Frente se posicione de forma amena, oscilando entre o caráter nacionalista e a atuação cultural.

Para além dos interesses coletivos envolvidos no teor das reivindicações dessas lideranças, nosso entendimento é que elas lutaram também por seus interesses individuais, opondo claramente o discurso à ação. A partir do momento em que resolveram caminhar na direção da política partidária e procuraram a concentração de poder em detrimento da união e das propostas coletivas, afastaram-se dos princípios estabelecidos em seus programas, que pregavam a elevação moral do negro, a integração à sociedade abrangente e o alcance da cidadania.

Apesar de tudo, pessoas representaram a Imprensa Negra dentro de suas convicções e incertezas, essas no período analisado, e foram fruto de seu tempo. Os conflitos, as decisões e os rumos tomados fizeram parte de suas escolhas, como para qualquer um de nós.

A decadência da Imprensa Negra em São Paulo e no Brasil não foi completa, pois anos depois aquelas lideranças estiveram presentes em outras publicações, divulgando seus trabalhos, questionando as decisões políticas e procurando defender suas ideias em prol do que entendiam ser a solução para os problemas dos afrodescendentes.

Infelizmente, tais problemas ainda são atuais. 


\section{FONTES PRIMÁRIAS}

\section{PERIÓDICOS - IMPRENSA NEGRA}

\section{Jornal}

Alvorada

O Alfinete.

O Alfinete.

O Alfinete.

Auriverde

Auriverde

Auriverde

O Bandeirante.

O Bandeirante.

O Bandeirante.

Chibata

O Clarim

O Clarim

O Clarim

O Clarim

O Clarim da Alvorada

O Clarim da Alvorada

O Clarim da Alvorada

O Clarim da Alvorada

O Clarim da Alvorada

O Clarim da Alvorada

O Clarim da Alvorada

O Clarim da Alvorada
Ano

1948

1918

1919

1921

1928

1928

1928

1918

1918

1919

1932

1924

1924

1924

1924

1925

1925

1926

1926

1926

1927

1928

1929
Número

$31 / 32$

2
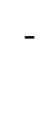

5

6

2

3

4

2

4

6

10

14

19

20

24

30

6

13

\section{Data/Edição}

maio 1948

3 set. 1918

4 jan. 1919

28 ago. 1921

8 abr. 1928

29 abr. 1928

13 mai. 1928

ago. 1918

set. 1918

abr. 1919

fev. 1932

6 jan. 1924

3 fev. 1924

6 abr. 1924

22 jun. 1924

25 jan. 1925

30 ago. 1925

21 mar. 1926

25 abr. 1926

22 ago. 1926

20 fev. 1927

1 jul. 1928

3 fev. 1929 
O Clarim da Alvorada

O Clarim da Alvorada

O Clarim da Alvorada

O Clarim da Alvorada

O Clarim da Alvorada

O Clarim da Alvorada

O Clarim da Alvorada

O Clarim da Alvorada

Elite.

Getulino.

Getulino.

Getulino.

Getulino.

Getulino.

Getulino.

Getulino.

Getulino.

Getulino.

Getulino.

Getulino.

Getulino.

Getulino.

Getulino.

Getulino.

Getulino.

Getulino.

Getulino.

Getulino.
1929

13 fev. 1929

13 mai. 1929

27 out. 1929

23 mai. 1930

28 set. 1930

28 set. 1931

31 jan. 1932

28 set. 1940

20 jan. 1924

29 jul. 1923

5 ago. 1923

9 set. 1923

13 out. 1923

28 out. 1923

4 nov. 1923

11 nov. 1923

18 nov. 1923

23 dez. 1923

30 dez. 1923

6 jan. 1924

2 mar. 1924

6 abr. 1924

22 jun. 1924

24 ago. 1924

14 set. 1924

21 set. 1924

28 set. 1924

12 out. 1924 


\begin{tabular}{|c|c|c|c|}
\hline Getulino. & 1924 & 64 & 20 dez. 1924 \\
\hline Getulino. & 1926 & $1^{*}$ & 13 mai. 1926 \\
\hline O Kosmos & 1922 & 3 & ago. 1922 \\
\hline O Kosmos & 1922 & - & nov. 1922 \\
\hline O Kosmos & 1924 & 25 & 22 jun. 1924 \\
\hline O Kosmos & 1925 & 30 & 25 jan. 1925 \\
\hline A Liberdade. & 1919 & 1 & 14 jul. 1919 \\
\hline A Liberdade. & 1920 & 15 & 9 mai. 1920 \\
\hline A Liberdade. & 1920 & 16 & 12 set. 1920 \\
\hline A Liberdade. & 1920 & 18 & 31 out. 1920 \\
\hline O Menelik & 1915 & 1 & 1 jan. 1915 \\
\hline O Menelik & 1915 & - & 17 out. 1915 \\
\hline O Menelik & 1916 & - & 1 jan. 1916 \\
\hline Monarquia & 1961 & 35 & jan-fev. 1961 \\
\hline O Novo Horizonte & 1946 & 1 & mai. 1946 \\
\hline O Novo Horizonte & 1954 & 64 & set. 1954 \\
\hline Patrocinio & 1928 & 31 & 7 set. 1928 \\
\hline Patrocinio & 1930 & 51 & 23 mar. 1930 \\
\hline Patrocinio & 1930 & 54 & 29 jun. 1930 \\
\hline Patrocinio & 1930 & 55 & 19 out. 1930 \\
\hline Progresso & 1928 & 6 & 15 nov. 1928 \\
\hline Progresso & 1929 & 12 & 26 set. 1929 \\
\hline Progresso & 1930 & 20 & 31 jan. 1930 \\
\hline Progresso & 1930 & 25 & 28 ago. 1930 \\
\hline Progresso & 1931 & 37 & 23 jun. 1931 \\
\hline Progresso & 1931 & 42 & 15 nov. 1931 \\
\hline Quilombo ** & 1950 & 5 & - \\
\hline Revista Evolução & 1933 & 6 & 1933 \\
\hline
\end{tabular}


A Rua

Senzala

Tribuna Negra

A Voz da Raça.

A Voz da Raça.

A Voz da Raça.

A Voz da Raça.

A Voz da Raça.

A Voz da Raça.

A Voz da Raça.

A Voz da Raça.

A Voz da Raça.

A Voz da Raça.

A Voz da Raça.

A Voz da Raça.

A Voz da Raça.

A Voz da Raça.

O Xauter

$* 3^{\text {a }}$ fase

** Rio de Janeiro

$* * * 2^{\mathrm{a}}$ fase
1916

3

1946

1945

1933

1933

1933

1933

1933

1933

1933

1933

1934

1934

1934

1935

1936

1937

1916
24 fev. 1916

jan. 1946

set. 1945

18 mar. 1933

25 mar. 1933

1 abr. 1933

18 mar. 1933

22 abr. 1933

29 abr. 1933

3 jun. 1933

6 jan. 1934

17 mar. 1934

26 mai 1934

15 dez. 1934

31 ago. 1935

ago. 1936

jul. 1937

16 mai. 1916 


\section{REFERÊNCIAS}

AISESEF - Compromisso da Venerável Irmandade de Santo Elesbão e Santa Efigênia do Rio de Janeiro, 1740, fols. 29-31 IN: OLIVEIRA, Anderson José Machado de. Op.Cit. p.14.

ALBUQUERQUE, Wlamyra Ribeiro de. Esperanças de Boaventuras: Construções da África e Africanismos na Bahia (1887-1910). Estudos Afro-asiáticos, ano 24, n.2, 2002, pp. 215-245. Disponível em <http://www.scielo.br/pdf/eaa/v24n2/a01v24n2.pdf> . Acesso 13 jun. 2009.

ALESSIO, Nancy. Urbanização, Industrialização e Estrutura Operacional, Dados, n. 7, 1970 IN: SILVA, Sérgio. Expansão Cafeeira e Origens da Indústria no Brasil. $7^{a}$. Edição. São Paulo. Editora Alfa-Omega, 1986, p.93.

AMARAL, Raul Joviano do. Os Pretos do Rosário. Subsídios Históricos. 1ª edição. São Paulo. Alarico, 1954.

ANAIS DO SENADO FEDERAL, sessão de 11 jul. 1924, Rio de Janeiro, Imp. Nacional, 1927 , p. 519.

ANDRADE, Margarida Maria de. Bairros Além-Tamanduateí: o imigrante e a fábrica no Brás, Móoca e Belezinho. Tese de doutoramento apresentada à FFLCH-USP, Departamento de Geografia. São Paulo, 1991.

ANDRADE, Mário de. O Movimento Modernista. Trecho de conferência realizada na Casa do Estudante, Rio de Janeiro, 1942, publicada em Aspectos da Literatura Brasileira, São Paulo, Livraria Martins Editora, s/d, p. 231-255 (1 $1^{\text {a }}$ edição: 1943). IN: SCHWARTZ, Jorge e POWER, Elizabeth. Brasil, 1920-1950: da antropofagia a Brasília. MAB-FAAP, Museu de Arte Brasileira, 30 nov 2002 a 2 mar 2003.São Paulo: Cosac Naify Edições, 2002, p. 475.

ANDREWS, George Reid. O protesto político negro em São Paulo (1888-1988), Estudos Afro-Asiáticos, n. 21, Rio de Janeiro, 1991, p.32.

ARRUDA, Maria Arminda do Nascimento. Assimilação marginal ao mundo do trabalho livre. São Paulo. Folha On-line: História do Brasil. Disponível em <http://www1.folha.uol.com.br/fol/brasil500/zumbi_29.htm> Último acesso em 29.06.2009.

AZEVEDO, Elciene. Orfeu de carapinha: a trajetória de Luiz Gama na imperial cidade de São Paulo. Campinas, UNICAMP, 1999.

BAER, Werner. A economia brasileira.2ª edição. São Paulo: Nobel, 2003, pp. 349-350.

BASTIDE, Roger. A imprensa negra do Estado de S. Paulo. Universidade de São Paulo. Faculdade de Filosofia, Ciências e Letras. Boletim CXXI. Sociologia $n^{\circ} 2$. Estudos AfroBrasileiros, 2a série, 1951.

A imprensa negra do Estado de São Paulo. In: Estudos Afro-brasileiros. São Paulo: Perspectiva, 1973, p. 132.

BASTIDE, Roger. FERNANDES, Florestan. Brancos e negros em São Paulo: ensaio sociológico sobre aspectos da formação, manifestações atuais e efeitos do preconceito de côr na sociedade paulistana. $2^{a}$. edição. São Paulo: Companhia Editora Nacional, 1959. 
BEIGUELMAN, Paula. A formação do povo no complexo cafeeiro: aspectos políticos. $2^{\mathrm{a}}$. ed. rev. e ampl., São Paulo, Pioneira, 1977. IN: ANDRADE, Margarida Maria de. Bairros AlémTamanduateí: o imigrante e a fábrica no Brás, Móoca e Belezinho.

BERND, Zilá. Poesia Negra Brasileira. Porto Alegre: Editora AGE, 1992.

BRAIDO, Jacyr F. As migrações na atualidade brasileira. IN: Migrantes: Êxodo Forçado. Centro de Estudos Migratórios. São Paulo: Edições Paulinas, 1980, p. 16.

BUTLER, Kim. Freedoms given, freedoms won: Afro-Brazilians in post-abolition, São Paulo and Salvador. ACLS Humanities, Latin American studies: Rutgers University Press, 1998, p. 105.

CARNEIRO, Maria Luiza Tucci e KOSSOY, Boris. A imprensa confiscada pelo DEOPS (1924-1954). Volume 1. Série Labirintos da Memória. São Paulo: Atelie Editorial, 2003.

CARONE, Edgar. PCB (1922-1943). São Paulo: Bertrand Brasil, 1982.

CARTA BIOGRÁFICA DE LUIZ GAMA A LÚCIO DE MENDONÇA, datada de 25 de julho de 1880. Disponível em <http://www.tropis.org/afro/luizgama.html>. Acesso em $21 \mathrm{de}$ junho de 2009.

CASTRO, Antonio Barros de. A economia política, o capitalismo e a escravidão. In: LAPA, José Roberto do Amaral (org.). Modos de Produção e realidade brasileira. Petrópolis: Vozes, 1980.

CASTRO, Hebe Maria Mattos de. Ao sul da história: lavradores pobres na crise do trabalho escravo. São Paulo: Brasiliense, 1987.

CEDAP Unesp Assis - Catálogo da Imprensa Negra, disponível em <http://www.assis.une sp.br/cedap/cat_imprensa_negra/biografias/lino_guedes.html>, Acesso 13 jun. 2009.

CHALHOUB, Sidney, Trabalho, Lar e Botequin, Campinas, UNICAMP, 2001, p.66.

COLEÇÃO DE DOCUMENTOS. Congresso Agrícola de 12 de junho de 1878. Rio de Janeiro: Tipografia Nacional, 1878. IN: JACINTO, Claudia Gaziolli Somma. Metáforas e analogias sobre o negro no Brasil. Revista História em Reflexão: Vol. $1 \mathrm{n}^{\mathrm{o}} 1$ - UFGD Dourados Jan/Jun 2007. Disponível em <http://www.historia emreflexao. ufgd.edu. br/meta foras.pdf>

COSTA, Emília Viotti. Da senzala à colônia, 2a . ed., São Paulo, 1982, p. 13 apud ANDREWS, George Reid. Negros e brancos em São Paulo (1888-1988). Bauru, EDUSC, 1998, pp. 95-96.

CUNHA, Olivia Maria Gomes e GOMES, Flávio dos Santos. Quase-cidadão: histórias e antropologias da pós-emancipação do Brasil. Rio de Janeiro: FGV editora, 2007, pp.315-346.

DAVIS, Horace. Padrão de vida dos operários na cidade de São Paulo. pp.113-66 IN: DECCA, Maria Auxiliadora Guzzo de. A vida fora das fábricas - cotidiano operário em São Paulo (1920-1934). Rio de Janeiro: Paz e Terra, 1987. p.21

DIAFÉRIA, Lourenço. A caminhada da esperança. São Paulo: Edições Loyola, 1996, p.71. 
DIAS, Everardo. História das lutas sociais do Brasil. São Paulo: Alfa-Omega, 1977, p.45, APUD DEACLETO, Marisa Midori. Comércio e vida urbana na cidade de São Paulo (18891930). São Paulo: Senac, 2002, p. 212.

DIAS, Márcia Lúcia Rebello Pinho. Desenvolvimento urbano e habitação popular em São Paulo (1870-1914). São Paulo: Ilustrada, 1989, p. 29.

DICK, Maria Vicentina de Paula do Amaral. A dinâmica dos nomes na cidade de São Paulo (1554-1897). São Paulo: Annablume, 1996, p. 174.

DONATO, Hernâni. Dicionário das Batalhas Brasileiras. Vol. 17 Estudos Brasileiros. São Paulo: Ibrasa, 1996.

DORNELlES, Beatriz. Porto Alegre em destaque: história e cultura. Porto Alegre: EDIPUCRS, 2004, p.48.

DUARTE, Paulo. Agora nós! s/l., s/ ed., s/d, várias páginas apud DEACLETO, Marisa Midori. Comércio e vida urbana na cidade de São Paulo (1889-1930). São Paulo: Senac, 2002, p. 212.

FOLHA DE SÃO PAULO, Caderno Especial Racismo, 23. 11.2008. Disponível em <http://www1.folha.uol.com.br/fsp/especial/inde23112008.htm> Acesso 25.11.2008.

FLOREAL, Sílvio. Ronda da meia-noite. São Paulo: Cupolo, 1925, p. 13. IN: DOMINGUES, Petrônio José. Op. Cit. p.324.

FRENTE NEGRA BRASILEIRA, 1930-1937 (trabalho de pesquisa cooperativo não publicado, Pontifícia Universidade Católica de São Paulo, 1985), anexo 2, sem paginação, apud ANDREW, George Reid. Negros e brancos em São Paulo (1888-1988) - Bauru, SP: EDUSC, 1998. pp. 113-114

FUNDAÇÃO CULTURAL PALMARES, Disponível em <http:// www.palmares. gov. br/ 003/00301009.jsp?ttCD_CHAVE=466>, acesso 13 jun. 2009.

GALVÃO, Walnice Nogueira. No calor da hora: a guerra de Canudos nos jornais, p.2 APUD SCHWARCZ, Lilian. Retrato em branco e preto: jornais, escravos e cidadãos em São Paulo no final do século XIX. São Paulo, Companhia das Letras, 1987, p. 64

GEBARA, Ademir. Evolução da Legislação Civil e o Problema da Indenização. IN: SZMRECSÁNYI, Tamás. LAPA, José Roberto do Amaral Lapa (org). História Econômica da Independência e do Império. Coletâna de Textos I Congresso Brasileiro de História Econômica. São Paulo: USP, setembro de 1993, p.96.

GONDIM, Eunice Ribeiro. Vida e obra de Paula Brito: iniciador do movimento editorial no Rio de Janeiro (1809-1861). Rio de Janeiro: Livraria Brasiliana, 1965, p. 17.

GOULART, Maurício. A escravidão africana no Brasil: das origens à extinção do tráfico. São Paulo: Alfa-Ômega,1975.

GRAHAM, Douglas H. \& HOLLANDA Filho, Sergio Buarque de. As migrações Interregionais e Urbanas e o Crescimento Econômico do Brasil Apud MOURA, Hélio Augusto de 
(Coord). Migração Interna: textos selecionados. Fortaleza: Banco do Nordeste do Brasil e Estudo Técnico de Estatísticas Econômicas do Nordeste-ETENE, pp.740-741.

INSTITUTO CULTURAL PORTAL AFRO, disponível em < http://www.portalafro.com.br/linoguedes.htm>, acesso 13 jun. 2009

JACINTO, Claudia Gaziolli Somma. Metáforas e analogias sobre o negro no Brasil. Revista História em Reflexão: Vol. $1 \mathrm{n}^{\mathrm{o}} 1$ - UFGD - Dourados Jan/Jun 2007. Disponível em <http://www.historiaemreflexao.ufgd.edu.br/metaforas.pdf>

JORNAL DA TARDE. “OS JORNAIS DOS NETOS DE ESCRAVOS”, Artigo, Jornal da Tarde (12 jun. 1975), p. 17.

KOWARICK, Lúcio. Trabalho e vadiagem: a origem do trabalho livre no Brasil. São Paulo, 1987, pp. 65-69.

LEI DE DIRETRIZES E BASES DA EDUCAÇÃO. Lei 10.639, de 9 de janeiro de 2003, que altera a Lei ${ }^{\circ}$ 9.394, de 20 de dezembro de 1996.

LOPES, Nei. Novo Dicionário Banto do Brasil. Rio de Janeiro: Pallas, 2003, p. 135.

MACIEL, Cléber da S. Discriminações Raciais: negros em Campinas (1888-1921). Campinas, Editora Unicamp, 1987. Série Campiniana.

MARCUS, Harold G. The Life and Time of Menelik II - Ethiopia (1844-1913). Oxford, Clarendon Press, 1975.

MARTINS, José de Souza. A imigração e a crise do Brasil agrário, p.63 a 73. IN: ANDRADE, Margarida Maria de. Bairros Além-Tamanduateí: o imigrante e a fábrica no Brás, Móoca e Belezinho.

MATTOS, Hebe Maria. Escravidão e cidadania no Brasil Monárquico. Rio de Janeiro: Jorge Zahar Editor, 2000.

MELLO, Francisco Figueira. Habitações Collectivas em São Paulo, IN Boletim da Sociedade de Medicina e Cirurgia de São Paulo, vol. IX, 3ª . Série, junho de 1926, n. 4, pp. 291-5, APUD DECCA, Maria Auxiliadora Guzzo. A vida fora das fábricas: cotidiano operário em São Paulo (1920-1934). São Paulo: Editora Paz e Terra, 1987, pp. 30-31.

MENUCCI, Sud. O precursor do abolicionismo no Brasil: Luiz Gama. São Paulo: Companhia Editora Nacional, 1938.

MONTEIRO, John Manuel. Negros da Terra: índios e bandeirantes nas origens de São Paulo. São Paulo: Companhiadas Letras, 1994.

MOTTA, Ubirajara Damaceno da. Jornegro: um projeto de comunicação afro-brasileira. São Paulo - 1978. Dissertação de Mestrado em Jornalismo - Instituto Metodista de Ensino Superior. São Bernardo do Campo, 1986, p. 48.

NORMANO, J.F. Evolução Econômica do Brasil, Companhia Editora Nacional, São Paulo, 1939, p. 144 IN: SILVA, Sérgio. Expansão Cafeeira e Origens da Indústria no Brasil. $7^{\mathrm{a}}$. Edição. São Paulo. Editora Alfa-Omega, 1986, p.93. 
SANT'ANNA, Nuto. Metrópole. Vol. XXXIX IN: QUINTÃO, Antonia Aparecida. Irmandades Negras: outro espaço de resistência (São Paulo: 1870-1890). Fapesp/Annablume. São Paulo: 2002. p. 13-14.

PENTEADO, Jacob. Belenzinho 1910: retrato de uma época. São Paulo, Martins, p. 172, $215-$ 218. IN: ANDRADE, Margarida Maria de. Brás, Moóca e Belenzinho: formação e dissolução dos antigos bairros "italianos" além-Tamanduateí. Travessia - Revista do Migrante. Ano XIII, número 38, setembro-dezembro 2000.

PETRONE, Maria Teresa S. A lavoura canavieira em São Paulo. São Paulo, 1968. IN: QUEIROZ, Suely Robles Reis de. Escravidão Negra em São Paulo: um estudo das tensões provocadas pelo escravismo no século XIX. Rio de Janeiro, J. Olympio; Brasília, INL, 1977.

PONCIANO, Levino. Bairros Paulistanos de A a Z. São Paulo: Senac, 2001, p. 29.

QUEIROZ, Maria Isaura Pereira de. Coletividades Negras. Ascensão sócio-econômica dos negros no Brasil e em São Paulo. São Paulo: Revista Ciência e Cultura, 1977.

QUINTÃO, Antonia Aparecida. Lá vem o meu parente: as irmandades de pretos e pardos no Rio de Janeiro e em Pernambuco (Século XVIII). São Paulo: Annablume: Fapesp, 2002, p.79.

RÉCLUS, Elisée. Nouvelle Géographie Universelle, t. 19, Paris, 1894, Hachette, p. 370-1. IN: ANDRADE, Margarida Maria de. Brás, Moóca e Belenzinho: formação e dissolução dos antigos bairros "italianos" além Tamanduateí. Travessia São Paulo. Ano XIII, número 38, setembro-dezembro/2002. p.5.

REIS, João José. Rebelião escrava no Brasil: a história do levante dos malês em 1835. ed. rev. e amp. - São Paulo: Companhia das Letras, 2003.

REIS, João José. GOMES, Flávio dos Santos, Liberdade por um fio - história dos quilombos no Brasil - São Paulo: Companhia das Letras, 1996.

REIS, João José, SILVA, Eduardo. Negociação e conflito - a resistência negra no Brasil escravista, Companhia das Letras, SP, 1989.

REIS, Nestor Goulart. São Paulo e outras cidades: produção social e degradação dos espaços urbanos. São Paulo: Hucitec, 1994.

RISÉRIO, Antonio. A utopia brasileira e os movimentos negros. São Paulo: Editora 34, 2007, p. 354.

ROCHA, Antonio Penalves. Ideias antiescravistas da Ilustração na sociedade escravista brasileira. Revista Brasileira de História, São Paulo, v. 20, nº 39, p.43-79, 2000.

RODRIGUES, Argemiro. Irmandade Nossa Senhora do Rosário dos Homens Pretos. São Paulo: Fundação Carlos Chagas. Caderno de Pesquisa nº 63, pp.137-138.

ROLNIK, Raquel. A cidade e a lei: política urbana e territórios na cidade de São Paulo. São Paulo: Studio Nobel, 1997, p. 63

ROY, Teresa Maria Malatian. A ação imperial patrianovista brasileira. Dissertação de Mestrado. São Paulo: PUC-SP, 1978. 
SANTANA, Frei José Pereira de. Os Dois Atlantes de Etiópia. Santo Elesbão, Imperador XLVII da Abissínia, Advogado dos perigos do mar \& Santa Efigênia, Princesa da Núbia, Advogada dos incêndios dos edifícios. Ambos Carmelitas. Lisboa: Oficina de Antonio Pedrozo Galram, 1735-1738 IN:OLIVEIRA, Anderson José Machado de. Devoção e identidades: significados do culto de Santo Elesbão e Santa Efigênia no Rio de Janeiro e nas Minas Gerais no Setecentos. TOPOI, v. 7, n. 12, jan-jun. 2006, pp.60-115. Disponível em <http://www.revistatopoi.org/numeros_anteriores/topoi12/topoi12a3.pdf> Acesso em 31 de maio de 2009.

SANTOS, Joel Rufino. Atrás do muro da noite: dinâmica das culturas afro-brasileiras. Brasília: Ministério da Cultura/Fundação Cultural Palmares, 1994, p. 157.

SANTOS, Gislene Aparecida dos. A invenção do "ser negro". São Paulo: Pallas, 2002, pp. 65-80.

SCHWARTZ, Stuart B. Escravos, roceiros e rebeldes. Bauru: EDUSC, 2001. p. 152-156. . Segredos Internos: trabalho escravo e vida escrava no Brasil. História: Questões \& Debates, v. 4, n. 6, p. 45-50, jun. 1983.

SEGAWA, Hugo M. Prelúdio da Metrópole: arquitetura e urbanismo em São Paulo na passagem do século XIX ao XX. São Paulo: Atelie Editorial, 2000 (2 ${ }^{a}$. ediç̧ão), pp.56-57

SEREZA, Haroldo Ceravolo. Leituras cruzadas: uma história cada vez mais bem contada. Folha de São Paulo, São Paulo, 30 nov. 2004. Caderno Sinopse. Disponível em <http://www1.folha.uol.com.br/folha/sinapse/ult1063u965.shtml>Acessado em 20 nov. 2007

SCHERER-WARREN, Ilse. Movimentos Sociais: um ensaio de interpretação sociológica, 2a . ed., Florianópolis, Ed. Da UFSC, 1987, p. 13.

SCHWARZ-BART, Simone; SCHWARZ-BART, André; DAVAL, Stephanie e VINOKUROV, Val. In Praise of Black Women: Heroines in the Slavery Era. University of Wisconsin Press, 2002. Disponível em <http://books.google.com.br/books?id=C5AfcnGEuQC\&dq=luiza+mahin\&as_brr=3\&source=gbs_navlinks_s $>$ Acesso em 19.08.2009.

SILVA, Luis Geraldo. A faina, a festa e o rito: uma etnografia histórica sobre as gentes do mar, sécs. XVII ao XIX. Campinas: Papirus, 2001, p. 66.

SIMONSEN, Roberto. Evolução Industrial do Brasil e outros estudos. Companhia Editora Nacional e Editora da USP, São Paulo, 1973.

SIQUEIRA, José Jorge. Entre Orfeu e Xangô: a emergência de uma nova consciência sobre a questão do negro no Brasil (1944-1968). São Paulo: Pallas, 2006, pp. 82-83.

SLENES, Robert. Família Escrava e Trabalho. Tempo - Revista do Departamento de História da UFF, Rio de Janeiro, v. 6, p. 37-42, 1998.

Na Senzala, Uma Flor: Esperanças e Recordações na Formação da Família Escrava (Brasil Sudeste, Século XIX) . Rio de Janeiro - RJ: Nova Fronteira, 1999. 
'Malungu, Ngoma vem'!: África coberta e descoberta no Brasil", Redescobrir os Descobrimentos: as Descobertas do Brasil, São Paulo, Revista USP, Ed. 12 (dez, jan, fev), 1990-1992.

SOUSA, João de. Vestigios da lingoa arabica em Portugal - Lexicon etymologico das palavras, e nomes portuguezes, que tem origem arabica. Academia Real das Sciencias de Lisboa (Typografia). Lisboa, 1830. Original da Harvard University. Digitalizado em 17 dez. 2007.Disponível em <http://books.google.com.br/books?id=iRMTAAAAYAAJ \&printsec $=$ titlepage $>$ Acesso 13 jun. 2009.

TAVARES, Luís Henrique Dias. História da Bahia (10a. ed.). São Paulo: Editora UNESP; Salvador (BA): EDUFBA, 2001.

VIANNA, Hélio. Contribuição à história da imprensa brasileira (1812-1869). Rio de Janeiro: Imprensa Nacional, 1945. 


\section{BIBLIOGRAFIA}

ANDREWS, George Reid, Negros e brancos em São Paulo (1888-1988) - Bauru, SP: EDUSC, 1998.

BARBOSA, Márcio. Frente Negra Brasileira: depoimentos/entrevistas e textos. São Paulo: Quilombhoje, 1998.

DEAN, Warren. A industrialização de São Paulo. São Paulo: Editora da Univesidade de São Paulo, 1971

COSTA, Iraci del Nero da. Nota sobre a não existência de modos de produção coloniais. São Paulo: IPE/USP, 1985.

. Repensando o modelo interpretativo de Caio Pradro Jr. São Paulo: Cadernos NEHD - FEA/USP, $n^{\circ} 3$.

COSTA, Iraci del Nero da. PIRES, Júlio. A fórmula do capital escravista-mercantil. Estudos Econômicos, v. 24. n 3, p. 527-532, set/dez.

DECCA, Maria Auxiliadora Guzzo. A vida fora das fábricas - cotidiano operário em São Paulo (1920-1934). Rio de Janeiro: Paz e Terra, 1987.

DIEESE, Caderno Estudos e Pesquisas, ano 3, número 37, novembro de 2007

DOMINGUES, Petrônio José. Uma história não contada: negro, racismo e branqueamento em São Paulo no pós abolição. São Paulo: Editora Senac São Paulo, 2004.

. A nova abolição. São Paulo: Summus, 2008

DUARTE, Paulo. História da Imprensa em São Paulo. Escola de Comunicações e Artes. Universidade de São Paulo, 1972.

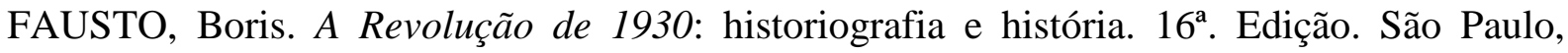
Companhia das Letras, 2008, p.38

FERNANDES, Florestan. A integração do negro na sociedade de classes. Tese de Cátedra em Sociologia. São Paulo, FFCL/USP, 1964.

A integração do negro na sociedade de classes: ensaio de interpretação sociológica. Vol. I e II. São Paulo: Globo, 2008.

A revolução burguesa no Brasil. Ensaio de Interpretação Sociológica. Rio de Janeiro: Zahar, 1976.

O Negro no mundo dos brancos. Corpo e Alma do Brasil, Difusão

Européia do Livro. São Paulo: 1972

FERRARA, Miriam Nicolau. A imprensa negra paulista (1915-1963). São Paulo, FFLCH/USP. Dissertação de Mestrado, 1981. Antropologia n. 13, 1986. 
FURTADO, Celso. Formação Econômica do Brasil. 25 ed., São Paulo: Editora Nacional, 1995.

GOMES, Flávio. Negros e Política (1888-1937). Jorge Zahar, 2005, pp.67-77

GORENDER, Jacob. O Escravismo Colonial. 6a . ed., São Paulo: Editora Ática, 1992. . A Escravidão Reabilitada. São Paulo: Ática/Secretaria de Estado da Cultura de São Paulo, 1990.

HOLANDA, Sergio Buarque de. Raízes do Brasil. - São Paulo: Companhia das Letras, 1999.

MORSE, Richard. A Formação Histórica de São Paulo. São Paulo, Difel, 1970.

MOTTA, José Flávio. COSTA, Iraci del Nero da. A formação econômica e social do Brasil sob nova ótica. Informações fipe. São Paulo: FIPE, nº 183, p. 18-22, dezembro 1995.

MOURA, Clóvis. Brasil: as raízes do protesto negro. São Paulo: Global Editora, 1983

Dialética radical do Brasil Negro. São Paulo: Ática, 1994, p. 211

Dicionário da Escravidão Negra no Brasil. São Paulo: Edusp, 2004.

O negro: de bom escravo a mau cidadão?, Editora Conquista, RJ, 1977.

. Os Quilombos e a rebelião negra. Coleção "Tudo é História”. Editora Brasiliense. $7^{\text {a }}$. Edição. São Paulo: 1987.

. Rebeliões da senzala - quilombos, insurreições, guerrilhas. Mercado Aberto, Porto Alegre, 1988 (1a edição: 1959).

Sociologia do negro brasileiro. São Paulo: Ática, 1988.

NOVAIS, Fernando. Portugal e Brasil na crise do antigo sistema colonial (1777-1808). São Paulo: Hucitec, 1979.

PIRES, Júlio. Costa, Iraci del Nero da. O capital escravista-mercantil: caracterização teórica e condições históricas de sua superação. Revista Estudos Avançados, 14 (38), 2000.

PRADO Jr., Caio. Evolução Política do Brasil. São Paulo: Editora Brasiliense, 1994 (edição original: 1933).

. Formação do Brasil Contemporâneo. 24a ed. São Paulo: Brasiliense, 1996.

QUEIROZ, Suely Robles Reis de. Escravidão Negra em São Paulo: um estudo das tensões provocadas pelo escravismo no século XIX. Rio de Janeiro, J. Olympio; Brasília, INL, 1977.

QUINTÃO, Antonia Aparecida. Irmandades Negras: outro espaço de luta e resistência (São Paulo: 1870-1890). São Paulo: Annablume, 2002

RAGO, Luzia Margareth. Do cabaré ao lar: a utopia da cidade disciplinar: Brasil 1890-1930. Rio de Janeiro: Paz e Terra, 1985.

RUSSEL-WOOD, A.J.R. Escravos e libertos no Brasil Colonial (The Black man in slavery and freedom in Colonial Brasil). Rio de Janeiro: Civilização Brasileira, 2005. 
SCHWARCZ, Lilia Mortiz. Retrato em branco e negro: jornais, escravos e cidadãos em São Paulo no final no século XIX. São Paulo: Companhia das Letras, 1987.

SILVA, Luiz (CUTI). ...E disse o velho militante: José Correia Leite. 19a. ed. São Paulo: Noovha América, 2007.

SILVA, Sérgio. Expansão Cafeeira e Origens da Indústria no Brasil. 7ª Edição. São Paulo. Editora Alfa-Omega, 1986, p.93.

SODRÉ, Nelson Werneck. História da Imprensa no Brasil. $1^{\text {a }}$ edição. São Paulo: Civilização Brasileira, 1966.

TEIXEIRA, Rodrigo Alves. O capital como sujeito e o "sentido da colonização". Artigo ANPEC, 2005. Disponível em <http://www.anpecorg.br/encontro2005/artigos/A05A017.pdf> 


\section{DISSERTAÇÕES E TESES}

MIRANDA, Rodrigo. Um caminho de suor e letras: a militância negra em Campinas e a construção de uma comunidade imaginada nas páginas do Getulino (Campinas, 1923-1926). Dissertação de Mestrado, Universidade Estadual de Campinas

OLIVEIRA, André Côrtes de. Quem é a Gente Negra Nacional? Frente Negra Brasileira e a Voz da Raça (1933-1937). Dissertação de Mestrado: Unicamp, 2006.

OLIVEIRA, Laiana Lannes de. A Frente Negra Brasileira: Política e Questão Racial nos anos 1930. Dissertação de Mestrado: UERJ, 2002.

PINTO, Ana Flávia Magalhães. De pele escura e tinta preta: a imprensa negra no século XIX (1833-1899). Dissertação de Mestrado. Universidade de Brasília, 2006.

PINTO, Regina Pahim. O movimento negro em São Paulo: luta e identidade. Tese de Doutorado, FFLCH, USP, 1993.

SANTOS, Pedro de Souza. Cidadania e educação dos negros através da imprensa negra em São Paulo (1915-1937). Dissertação de Mestrado, Universidade São Francisco, Itatiba, 2007. 


\title{
Dados para Contato
}

Dissertação: A IMPRENSA NEGRA PAULISTA ENTRE 1915 E 1937: CARACTERÍSTICAS, MUDANÇAS E PERMANÊNCIAS.

\author{
Aluno: $\quad$ Gilmar Luiz de Carvalho \\ RGM: $\quad 5248090$ \\ e-mail: $\quad$ gicarva@usp.br \\ mg_carvalho@uol.com.br \\ gilmar.carvalho@hp.com \\ Fone: $\quad 1120521407$ (residência) \\ 1199072479 (celular)
}

